\author{
UNIVERSIDADE DE SÃO PAULO \\ FACULDADE DE ODONTOLOGIA DE RIBEIRÃO PRETO
}

QUANTIFICAÇÃO DO POTENCIAL OSTEOGÊNICO IN VIVO DO OSSO AUTÓGENO + CÉLULAS OSTEOBLÁSTICAS CARREADAS POR UMA BIOCERÂMICA COMPOSTA DE HIDROXIAPATITA E FOSFATO TRICÁLCIO-ß: ESTUDO QUALITATIVO E QUANTITATIVO EM MICROSCOPIA DE LUZ E ELETRÔNICA DE VARREDURA.

Rander Moreira Macedo

Ribeirão Preto 2013 


\title{
QUANTIFICAÇÃO DO POTENCIAL OSTEOGÊNICO IN VIVO DO OSSO AUTÓGENO + CÉLULAS OSTEOBLÁSTICAS CARREADAS POR UMA BIOCERÂMICA COMPOSTA DE HIDROXIAPATITA E FOSFATO TRICÁLCIO-ß: ESTUDO QUALITATIVO E QUANTITATIVO EM MICROSCOPIA DE LUZ E ELETRÔNICA DE VARREDURA.
}

\author{
Tese apresentada à Faculdade de \\ Odontologia de Ribeirão Preto da \\ Universidade de São Pulo para obtenção \\ do título de Doutor em Odontologia. \\ Área de Concentração: Reabilitação Oral
}

Orientador: Prof. Dr. Luiz Guilherme Brentegani Co-orientadora: Profa. Dra. Suzie Aparecida de Lacerda

Ribeirão Preto 


\section{AUTORIZO A REPRODUÇÃO E DIVULGAÇÃO DO TEOR TOTAL OU PARCIAL DESTE TRABALHO POR QUALQUER MEIO CONVENCIONAL OU ELETRÔNICO, PARA FINS DE ESTUDO E PESQUISA, DESDE QUE CITADA A FONTE.}

Ficha catalográfica elaborada pela Biblioteca Central do Campus USP - Ribeirão Preto

Macedo, Rander Moreira

Quantificação do potencial osteogênico in vivo do osso autógeno + células osteoblásticas carreadas por uma biocerâmica composta de hidroxiapatita e fosfato tricálcio- $\beta$ : Estudo qualitativo e quantitativo em microscopia de luz e eletrônica de varredura. Ribeirão Preto, 2013.

233 p. : il. ; $30 \mathrm{~cm}$

Tese de Doutorado, apresentada à Faculdade de Odontologia de Ribeirão Preto/USP. Área de concentração: Reabilitação Oral.

Orientador: Brentegani, Luiz Guilherme.

Co-orientadora: Lacerda, Suzie Aparecida de.

1. Reparação óssea. 2. Biocerâmica. 3.Células osteoblásticas.

4. Osso autógeno. 5. Histometria. 6. Microscopia eletrônica de varredura. 


\section{FOLHA DE APROVAÇÃO}

\section{Rander Moreira Macedo}

Quantificação do potencial osteogênico in vivo do osso autógeno + células osteoblásticas carreadas por uma biocerâmica composta de hidroxiapatita e fosfato tricálcio- $\beta$ : Estudo qualitativo e quantitativo em microscopia de luz e eletrônica de varredura.

Tese apresentada à Faculdade de
Odontologia de Ribeirão Preto da
Universidade de São Pulo para obtenção do
título de Doutor em Odontologia.
Área de Concentração: Reabilitação Oral

Aprovado em:

\section{Banca Examinadora}

Prof.(a) Dr.(a)

Instituição:

Julgamento:

Assinatura

Prof.(a) Dr.(a)

Instituição:

Julgamento:

Assinatura

Prof.(a) Dr.(a)

Instituição:

Julgamento:

Assinatura

Prof.(a) Dr.(a)

Instituição:

Julgamento:

Assinatura

Prof.(a) Dr.(a)

Instituição:

Julgamento:

Assinatura 
À Deus, que sempre norteou meu caminho. Deu-me forças nos momentos de cansaço; bom senso, sabedoria e discernimento nos momentos de dúvida, e com certeza me presenteou com os momentos de felicidade.

Aos meus maravilhosos pais, Dasy Lúcyde Moreira Macedo, pelo carinho, amor incondicional e renúncia em prol da dedicação suprema aos filhos, e Rogerio Macedo, também pelo amor, amizade e sempre fazendo o impossível para que os nossos sonhos se tornassem reais.

Aos meus irmãos Breno Moreira Macedo e Ruan Moreira Macedo, por serem os meus melhores amigos e sempre estarmos unidos, mesmo à distância, seja nas horas do choro do fracasso, ou da vibração recíproca das vitórias.

À minha namorada Renata Alessi Rosa, pela amizade, amor, carinho, paciência, companheirismo e apoio na conquista deste sonho. 
Ao Prof. Dr. Luiz Guilherme Brentegani, pelo exemplo de caráter, educação e honestidade. Sempre disposto a dividir seus conhecimentos, os anos de convívio desde a iniciação científica me propiciaram enriquecer tanto intelectualmente quanto humanamente, observando o seu jeito único e paciencioso de tratar as pessoas seja nas questões acadêmicas ou no cotidiano. Obrigado por tudo! 


\section{AGRADECIMENTOS}

À Faculdade de Odontologia de Ribeirão Preto da Universidade de São Paulo que me acolheu em 2003 ainda de cabeça raspada, e bastante assustado pelas mudanças bruscas que aconteciam rapidamente na minha vida. Agradeço por ter sido a minha segunda casa, me proporcionado formação profissional e agora um título que não imaginava um dia conseguir.

Ao Departamento de Materiais Dentários e Prótese e seus respectivos docentes por guiar minha formação acadêmica, e também ao Departamento de Morfologia, Estomatologia e Fisiologia, pelo acolhimento durante todos estes anos, e por possibilitar o desenvolvimento desta tese.

À Prof. Dra. Suzie Aparecida de Lacerda, pela criteriosa e fundamental colaboração, nas diversas fases da execução deste trabalho, além da amizade construída durante os anos de convívio.

À Prof. Dra. Karina Fittipaldi Bombonato Prado, e à doutoranda Maidy Rehder Wimmers Ferreira pela gentileza em elaborarem as células tronco utilizadas nesta pesquisa e pela pacienciosa missão em solucionar minhas dúvidas.

Ao Prof. Dr. José Antônio Thomazini, pela imprescindível colaboração neste estudo e pela prontidão em realizar com maestria as análises ao microscópio eletrônico de varredura.

À Prof. Dra. Fernanda de Carvalho Panzeri Pires de Souza, coordenadora do programa de pós-graduação em Reabilitação Oral da FORP-USP.

Aos técnicos do laboratório de histopatologia, Edna A. S. Moraes, Gilberto André e Silva e Kleber Augusto Loreiro, pela paciência e dedicação na confecção das lâminas histológicas e Adriana de Matos G. Silva, pela companhia e auxílio durante os procedimentos cirúrgicos realizados nos animais. 
Aos técnicos Antônio Sérgio A. Mesca e Antônio Massaro, pelo amor e os impecáveis cuidados com os animais no biotério.

Aos técnicos do laboratório de Cultura de Células, em especial Roger Rodrigo Fernandes pelo auxílio durante os procedimentos de elaboração das células tronco.

Aos técnicos do Laboratório de Microscopia Eletrônica da Faculdade de Medicina de Ribeirão Preto, José Augusto Maulin e Maria Dolores Seabra Ferreira pela disponibilidade em preparar as amostras analisadas ao microscópio eletrônico de varredura.

Às secretárias do programa de Pós-Graduação em Reabilitação Oral, Regiane de Cássia Tirado Damasceno e Fernanda Talita de Freitas, pelo prontidão e disponibilidade em resolver as questões por mim solicitadas.

Às secretárias da pós-graduação, Isabel Cristina C. Galino e Regiane Cristina Moi Sacioloto, pelos cuidados e atenção aos quesitos burocráticos deste curso de pós-graduação.

À secretária do departamento de Morfologia, Estomatologia e Fisiologia, Rosângela A. da Silva Troca Nascimento, pela disponibilidade e atenção durante este período.

À Faculdade de Medicina de Ribeirão Preto da Universidade de São Paulo, em especial ao Departamento de Biologia Celular e Molecular e Bioagentes Patogênicos pela possibilidade de utilização do microscópio eletrônico de varredura como meio auxiliar neste estudo.

Aos meus avós, Ivadir Faria Moreira e Dilma Helena Lourenço Moreira, Elpídio Macedo (in memória) e Maria Ivete Macedo, pelo exemplo de superação das dificuldades enfrentadas na vida e pelo êxito em formar famílias tão brilhantes. 
Às minhas tias Denise, Delvânia, Rejane, e tios Celso e Décio, por estarem sempre presentes e vibrantes com minhas conquistas.

Aos meus Primos Thiago, Caio, Pablo e Denis, pelos momentos de descontração e união vividos juntos.

Ao amigo e praticamente irmão, João Ricardo L. Macedo Pereira, pela amizade sincera, pelo apoio e por sempre me lembrar de que nunca devemos desistir frente aos obstáculos que encontramos.

Ao amigo, colega de graduação, mestrado e doutorado, Diogo Rodrigues Cruvinel, por ter me ajudado sem objeções inúmeras vezes seja nos afazeres acadêmicos ou pessoais. Por termos tido muitos momentos de descontração regados a deliciosas risadas que sempre me lembrarei com alegria, e termos buscado a cada dia que passa fortalecer ainda mais esta grande amizade.

Aos amigos Ricardo Leão Castilho e Lucas Leão Castilho, pelos anos de convívio, companheirismo e amizade.

Aos colegas de Doutorado, Ana Carolina M. Villela Rosa, Ana Paula Terossi de Godoi, Daniela N. Borges Felipucci, Diogo Rodrigues Cruvinel, Fábio A. Aguiar Júnior, Flávio H. C. N. Fernandes, Murillo Sucena Pita, Rômulo Rocha Régis, Vitor Coró, pela convivência e oportunidade de compartilharmos conhecimento.

Aos colegas de residência no Hospital de Reabilitação de Anomalias Craniofaciais - Centrinho USP Bauru, Camila Camarinha Cirino, Débora Amgarten Ribeiro, Gabriela Letícia Natalício, Mariana Monteiro, Mércia J. S. Cunha, Paula G. F. Pessôa Oliveira e Vitor E. Albino Garcia e aos professores Ana Lúcia P. F. Almeida, Sueli Lobo Devides, Luis Augusto Esper, Caio Márcio Figueiredo e Flávio Monteiro Amado pela amizade, entendimento e colaboração nas vezes em que me ausentei para me dedicar a este trabalho. 
Aos Animais utilizados nesta pesquisa, pois sem eles nada disso teria sido possível, e também por cederem o bem mais precioso para que isto se tornasse concreto, a vida. 
O estudo, a busca da verdade e da beleza são domínios em que nos é consentido sermos crianças por toda a vida.

Albert Einstein 


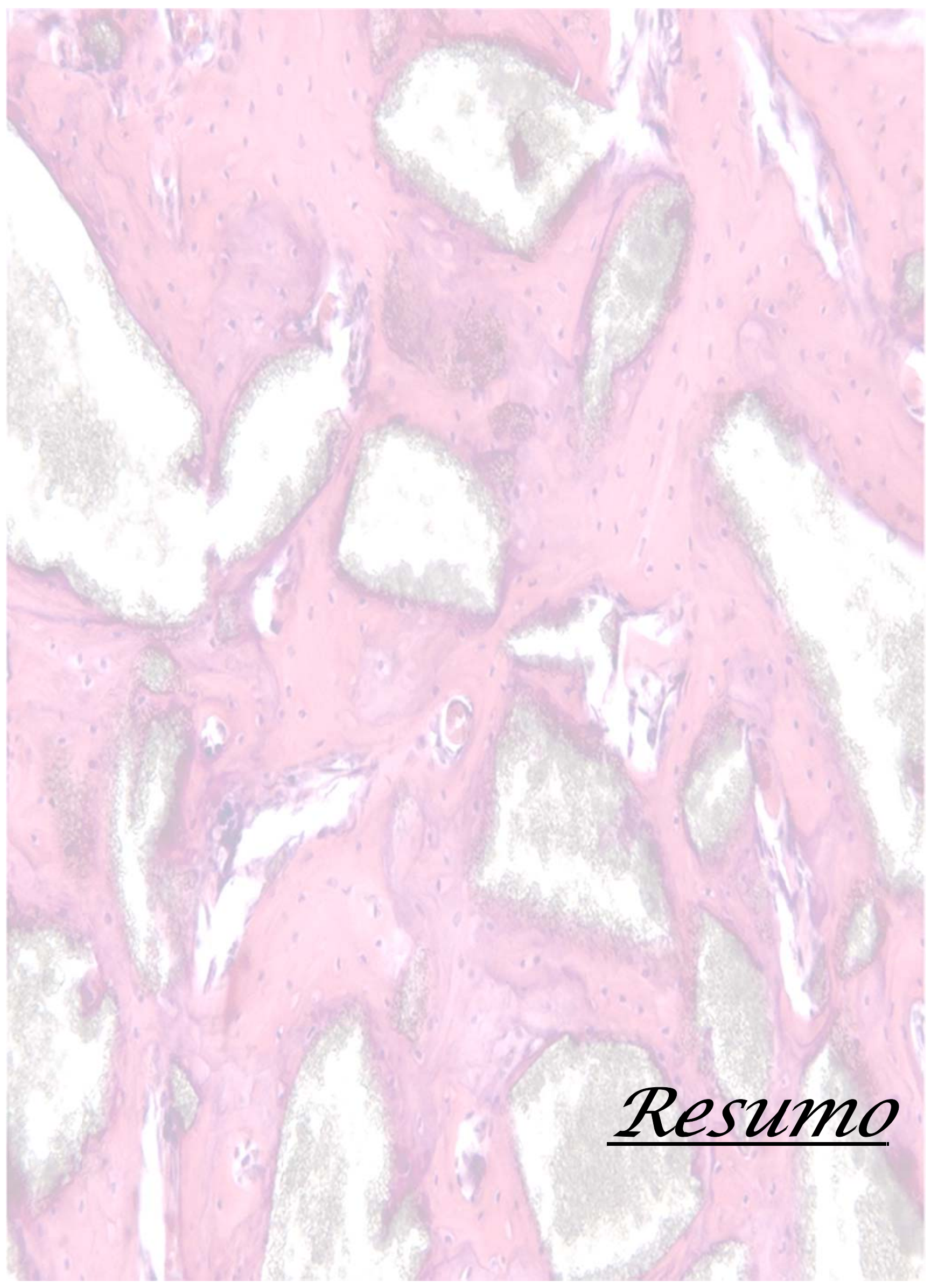


MACEDO, R.M. Quantificação do potencial osteogênico in vivo do osso autógeno + células osteoblásticas carreadas por uma biocerâmica composta de hidroxiapatita e fosfato tricálcio- $\beta$ : Estudo qualitativo e quantitativo em microscopia de luz e eletrônica de varredura. Ribeirão Preto, 2013. 233 p. Tese (Doutorado) - Faculdade de Odontologia de Ribeirão Preto, Universidade de São Paulo.

\section{Resumo}

Durante e após o processo de reparo alveolar pós-extração, ocorre certa remodelação óssea com reduções dimensionais deste tecido podendo comprometer a terapia em implantodontia. A fim de preservar/reconstruir tal tecido, vários métodos são propostos usando diferentes tipos de biomateriais e técnicas, os quais demonstram capacidade em formar osso. O osso autógeno ainda é considerado a referência padrão como enxerto ósseo, devido ao seu potencial osteogênico, osteoindutor e osteocondutor, mas morbidade relativa a este é conhecida. Por isso algumas biocerâmicas têm sido utilizadas, pois são sintéticas, biocompatíveis e com boas propriedades osteopreenchedoras, mas com baixa osteogenicidade. A engenharia tecidual óssea constituída de células tronco mesenquimais diferenciadas em osteoblastos é uma estratégia para o fornecimento adicional celular ao defeito ósseo em reconstrução. O objetivo deste estudo foi qualificar e quantificar a reparação óssea após o enxerto de uma associação de osso autógeno e células osteoblásticas carreadas por uma biocerâmica em defeitos ósseos produzidos pela extração dentária. Os animais foram divididos de acordo com o material implantado no alvéolo dentário pós-extração em: Controle (c), osso autógeno (oa), células osteoblásticas (co), biocerâmica (bc), osso autógeno + células osteoblásticas $(\mathrm{oa}+\mathrm{co})$, osso autógeno + biocerâmica (oa+bc), biocerâmica + células osteoblásticas $(b c+c o)$, e biocerâmica + células osteoblásticas + osso autógeno $(b c+c o+o a)$. 0 sacrifício ocorreu aos 7, 21 e 42 dias pós-cirurgia e as amostras teciduais foram processadas para análise em microscopia de luz e eletrônica de varredura. Através de um sistema de análise de imagens foi avaliado a qualidade dos biomateriais implantados e o volume de osso, biocerâmica, conjuntivo e coágulo no defeito ósseo. Os resultados qualitativos revelaram que a biocerâmica implantada foi biocompatível e estava intimamente unida ao osso. $O$ uso das células osteoblásticas, do osso autógeno ou da biocerâmica não desencadearam reações imunogênicas, de corpo estranho ou formação tumoral. Histometricamente as células osteoblásticas carreadas pela biocerâmica mostraram um preenchimento ósseo 19,0\% maior do que quando não carreadas. A associação biocerâmica/células osteoblásticas + osso autógeno promoveu, aos 7 dias, uma deposição óssea $56,52 \%$ mais efetiva nos arredores do biomaterial do que a enxertia da biocerâmica isoladamente (1\%). Conclui-se que a biocerâmica em questão pode ser um viável carreador às células osteoblásticas a serem enxertadas em sítios de reconstrução óssea, e que este composto híbrido recebe um efeito sinérgico quando da associação ao osso autógeno, sendo capaz desta forma de acelerar o processo de neoformação óssea principalmente nos períodos iniciais da reparação alveolar.

Palavras chaves: Reparação óssea, biocerâmica, células osteoblásticas, osso autógeno, histomorfometria, microscopia eletrônica de varredura. 


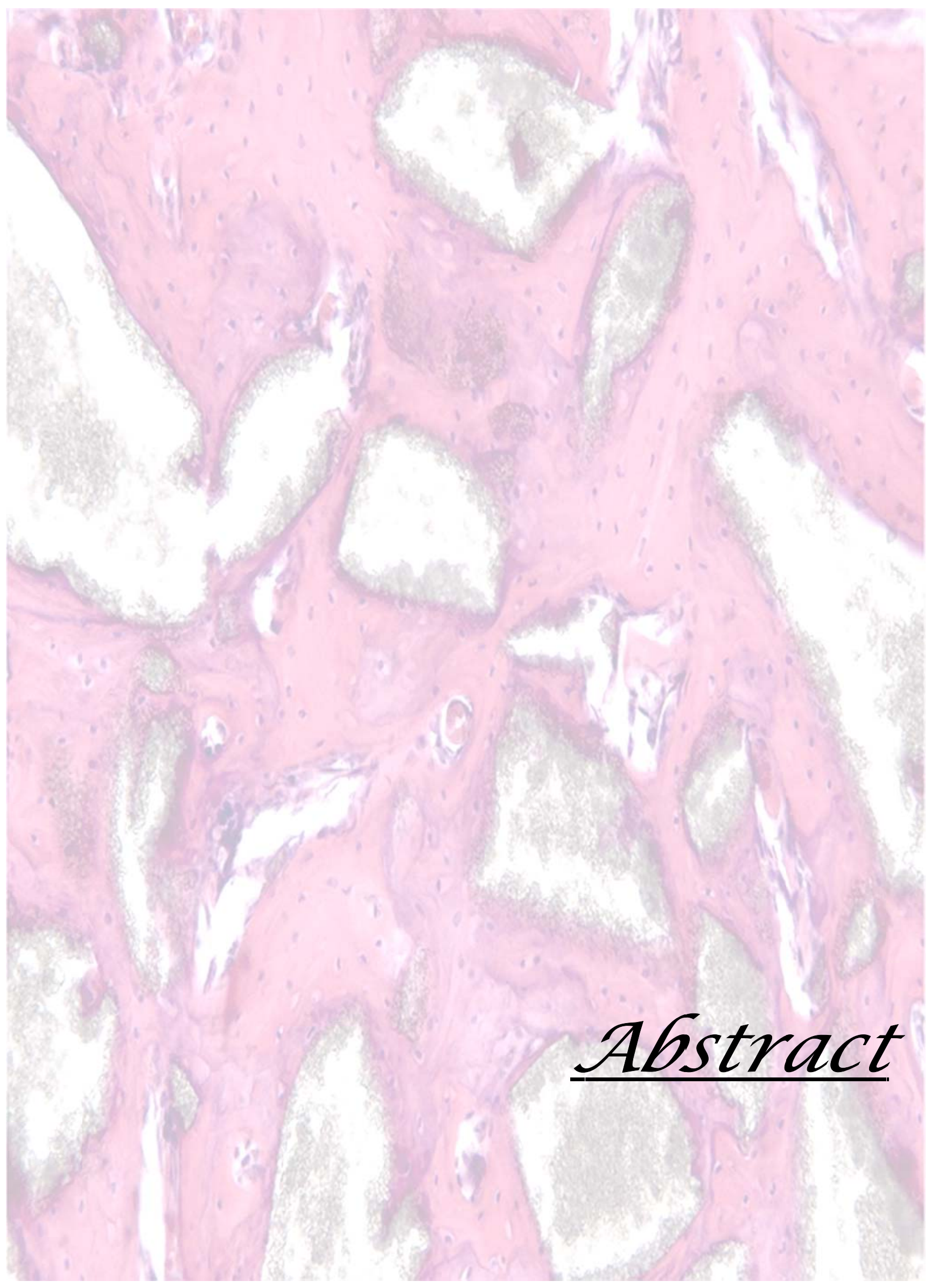


MACEDO, R.M. Quantification of the osteogenic potential in vivo of autogenous bone + osteoblastic cells carried by a bioceramic consisting of hydroxyapatite and $\beta$-tricalcium phosphate: $A$ qualitative and quantitative study by light and scanning electron microscopy. Ribeirão Preto, 2013. 233 p. Thesis (PhD) Ribeirão Preto School of Dentistry, University of São Paulo.

\section{Abstract}

During and after the process of alveolar repair post-extraction, bone remodeling occurs with certain dimensional reductions of this tissue that can compromise the therapy in implantology. In order to preserve/reconstruct such tissue, various methods are proposed using different types of biomaterials and techniques which demonstrate the capacity to form bone. The autogenous bone is still regarded as the gold standard bone graft, due to their osteogenic, osteoinductive and osteoconductive potential, but morbidity is known about it. Therefore some bioceramics have been used, as they are synthetic, biocompatible and with good properties of bone fill, but with low osteogenic potential. The bone tissue engineering consists of mesenchymal stem cells differentiated into osteoblasts is a strategy for providing additional cell in the bone defect reconstruction. The aim of this study was to qualify and quantify bone healing after grafting of an association of autogenous bone and osteoblastic cells carried by a bioceramic in bone defects produced by tooth extraction. The animals were divided according to the implanted material in dental socket after extraction: Control (c), autogenous bone (ab), osteoblastic cells (oc), bioceramic (bc), autogenous bone + osteoblastic cells $(a b+o c)$, autogenous bone + bioceramic $(a b+b c)$, bioceramic + osteoblastic cells $(b c+o c)$, and bioceramic + autogenous bone + osteoblastic cells $(b c+o c+a b)$. The animals were sacrificed at 7, 21 and 42 days post-surgery and tissue samples were processed for light microscopy and scanning electron microscopy. Through an image analysis system the quality of implanted biomaterials and the volume of bone, bioceramic, conjunctive tissue and blood clot was evaluated inside the bone defect. Qualitative results revealed that the grafted bioceramic was biocompatible and intimately bonded with the bone. The use of osteoblastic cells, autogenous bone or bioceramic didn't trigger immunogenic reactions, foreign body or tumor formation. Histometrically, the osteoblast cells carried by bioceramic showed a bone filling $19.0 \%$ higher than when not carried. The bioceramic/osteoblastic cells + autogenous bone association promoted, at 7 days, a bone deposition $56.52 \%$ more effective around the biomaterial than the grafting of bioceramic alone $(1 \%)$. It was concluded that the bioceramic in question may be a viable carrier to osteoblastic cells to be grafted on sites of bone reconstruction, and this hybrid compound receives a synergistic effect when associated to autogenous bone, thus being able to accelerate the bone formation especially in the early periods of alveolar repair.

Keywords: Bone Repair, bioceramic, osteoblastic cells, autogenous bone, histomorphometry, scanning electron microscopy. 


\section{SUMÁRIO}

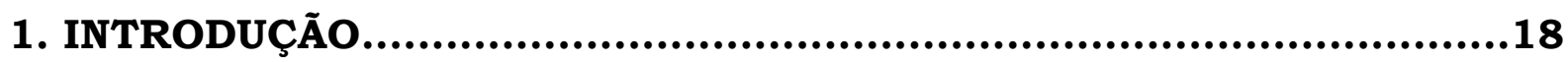

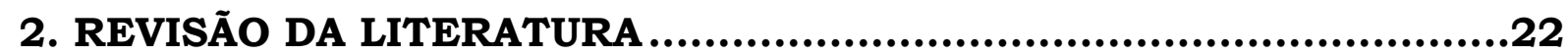

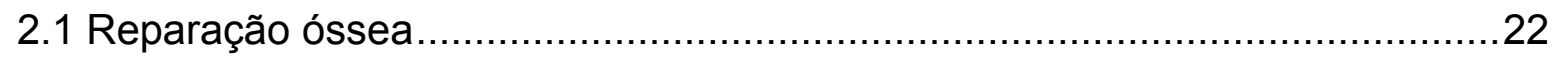

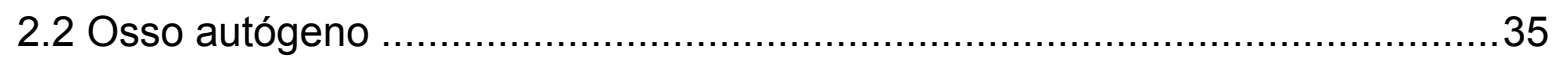

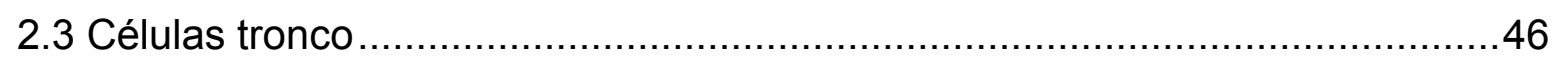

2.3.1 Conceitos, Origens, Definições e Propriedades ...................................46

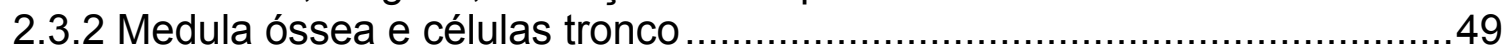

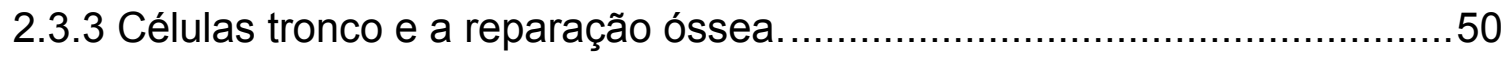

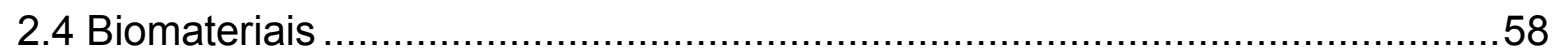

2.4.1 Conceitos, Classificações, Definições e Propriedades..............................58

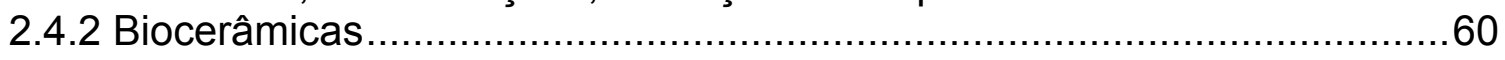

2.4.2.1 Biocerâmicas a base de Fosfato de Cálcio .........................................63

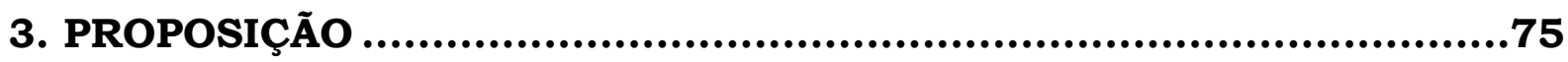

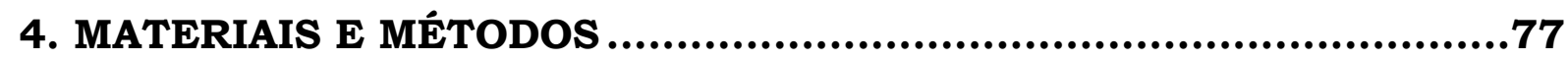

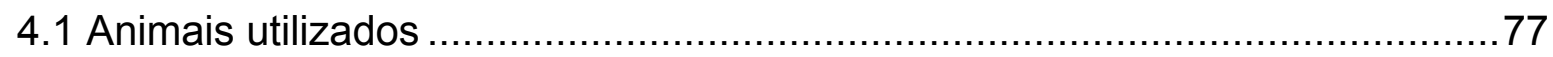

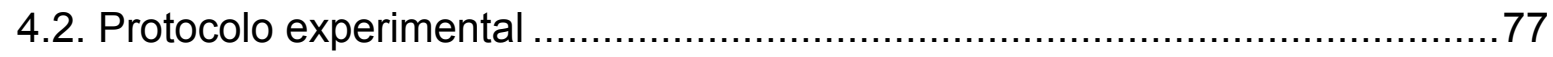

4.3 Cultura de células de medula óssea de ratos .............................................

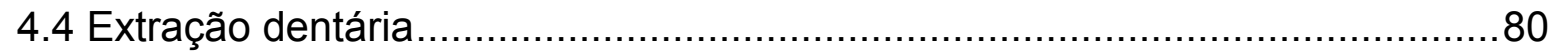

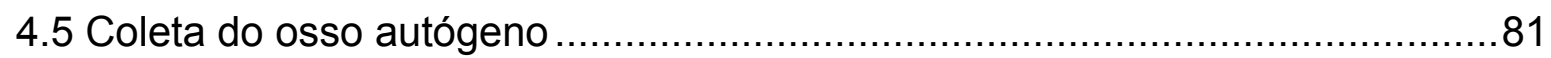

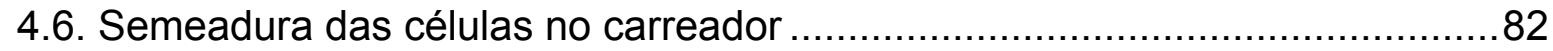

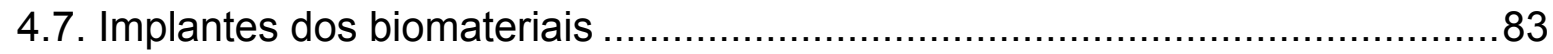

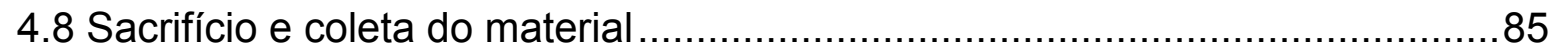

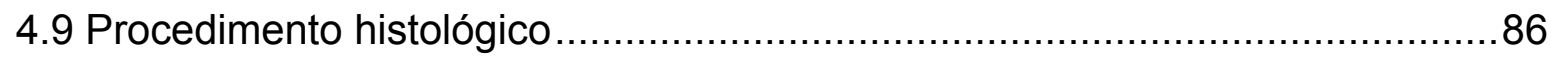

4.10 Processamento das amostras para microscopia eletrônica de varredura......86

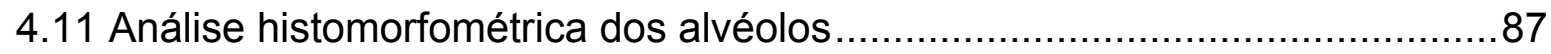

4.12 Análise em microscopia eletrônica de varredura ......................................89

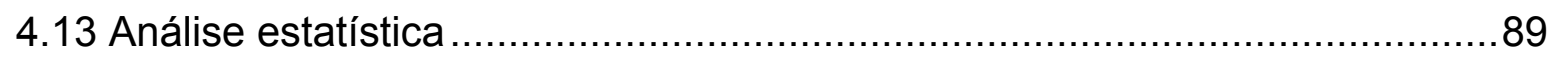


5.1. Resultados histológicos em microscopia de luz...................................91

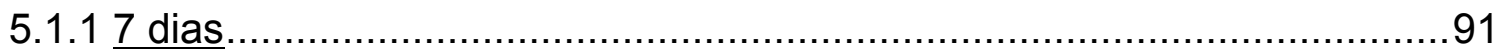

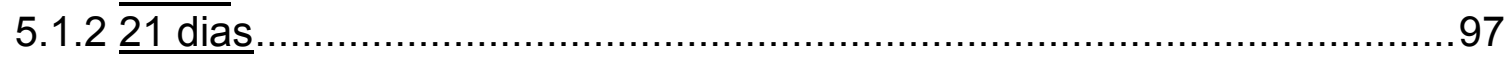

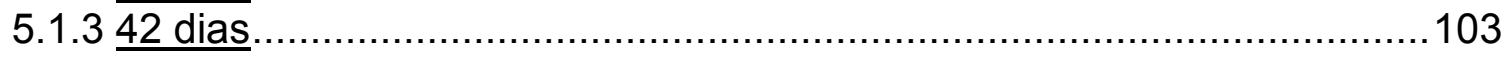

5.2 Resultados histológicos em microscopia eletrônica de varredura .................109

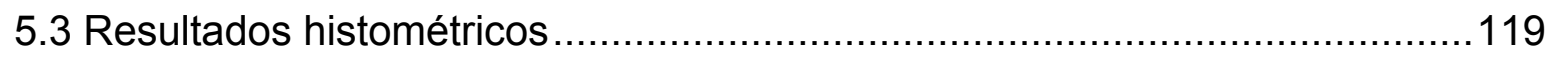

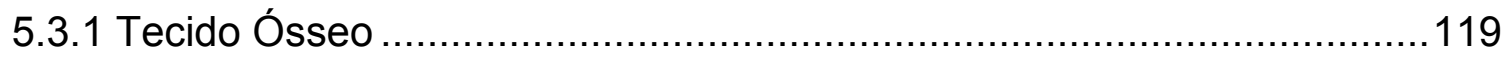

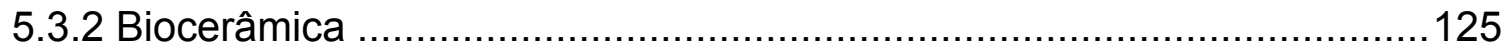

5.3.3 Tecido Conjuntivo..................................................................... 138

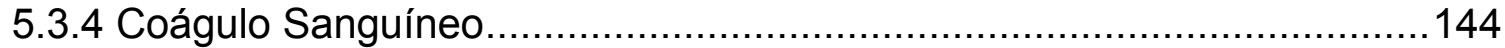

6. DISCUSSÃO

6.1. Modelo experimental de reparação óssea ........................................151

6.2 Osso autógeno e reparação óssea ................................................... 155

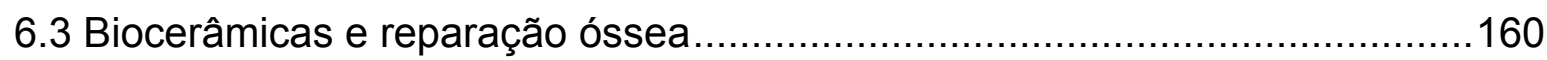

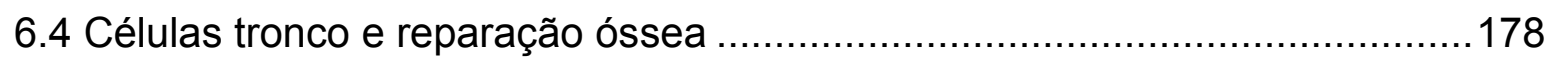

6.5 Biocerâmica e células tronco na reparação óssea ....................................184

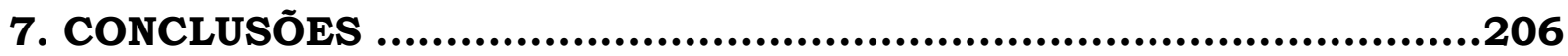

8. REFERÊNCIAS BIBLIOGRÁFICAS ..........................................208

9. ANEXO 


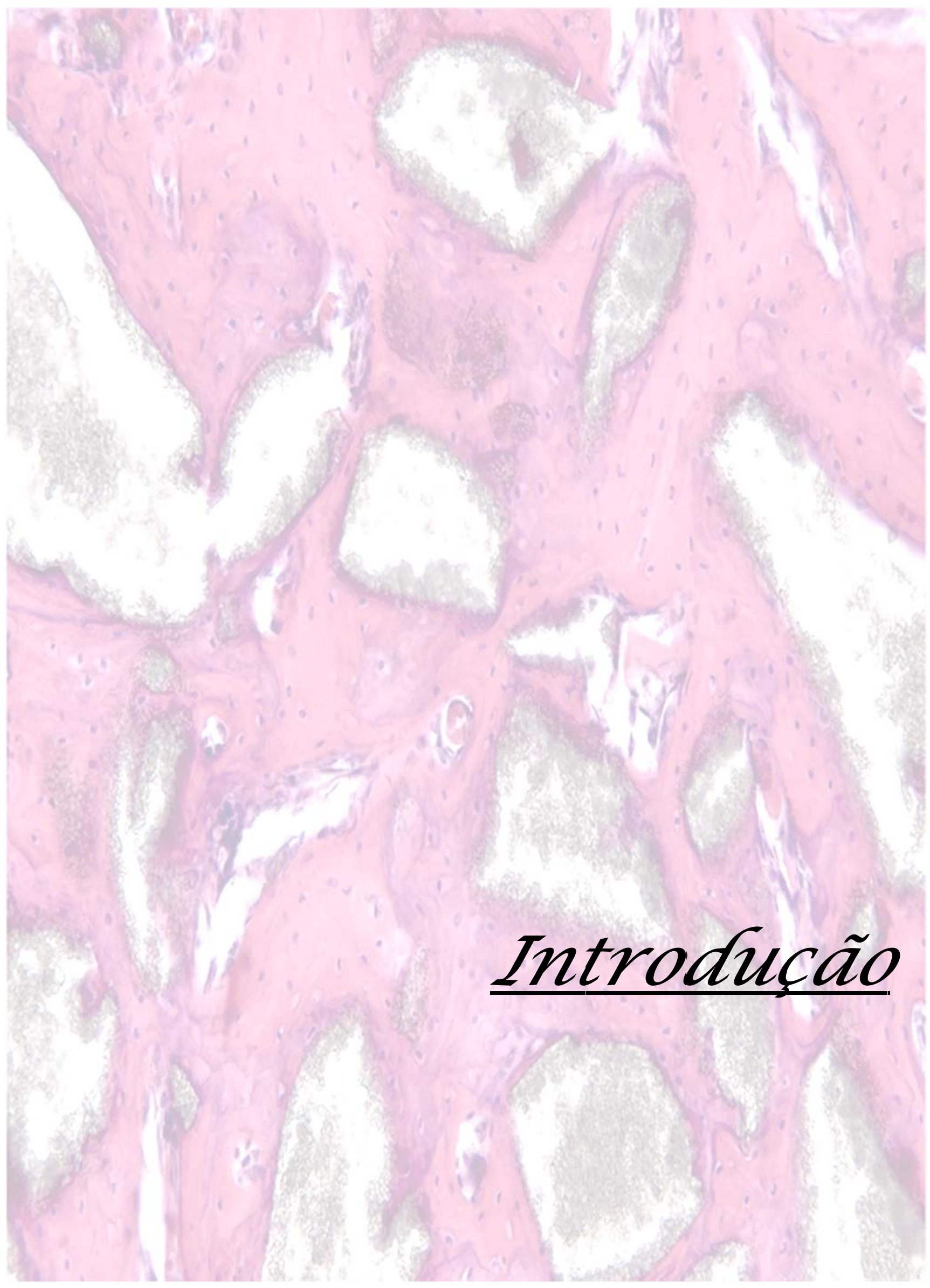




\section{Introdução}

O processo de reparação de feridas de extração dentária, ou processo de reparação alveolar, refere-se ao conjunto de reações teciduais desencadeadas no interior do alvéolo, em seguida à exodontia. Este fenômeno, extremamente ordenado, mantem uma reação inflamatória estreitamente entrelaçada com o reparo (Devlin e Sloan, 2002). O organismo tem como objetivo, frente a um traumatismo após a extração dentária, preencher com tecido ósseo o espaço deixado no alvéolo, de modo que a reparação alveolar se completa quando existem trabéculas ósseas espessas, espaços medulares diminutos, e a crista alveolar já está remodelada (Ahn e Shin, 2008). Sabe-se que fatores tanto sistêmicos como locais, modulam a formação, reabsorção, remodelação e, consequentemente, a reparação óssea nos alvéolos dentais (Carvalho e Okamoto, 1987).

Vários métodos são propostos para a regeneração de defeitos ósseos, entre eles, o uso de diferentes tipos de biomateriais e técnicas, os quais demonstram capacidade em promover a formação óssea. Entretanto, muitos deles não são ideais e muitos não serão substituídos por osso durante muitos anos, se é que serão (Esposito et al., 2006).

O osso autógeno é considerado o "padrão ouro" como enxerto ósseo, devido as suas vantagens biológicas e ao seu já conhecido potencial osteogênico, osteoindutor e osteocondutor (Chen et al., 2011;), atuando dessa forma como modelo para a neoformação óssea (Manso e Lang, 1997). Apesar das inúmeras vantagens em relação às demais técnicas no que se refere à biocompatibilidade e ao potencial regenerador ósseo (Macedo et al., 2011), a experiência clínica e 
trabalhos experimentais mostram limitações quanto ao ganho efetivo de volume ósseo ao longo do tempo (Salata et al., 2002; Araújo e Lindhe, 2011), bem como ao aumento da morbidade relacionada ao procedimento cirúrgico (Cordaro et al., 2010).

Com o intuito de eliminar estes problemas, substitutos ósseos sintéticos têm sido desenvolvidos e são hoje usados em grande parte das cirurgias ósseas reconstrutivas (Lindgren et al., 2012). A aplicação de materiais a base de cerâmicas de fosfato de cálcio bifásicas como enxertos ósseos, tem recebido considerável atenção devido a notável biocompatibilidade (Chapard et al., 2010) e propriedades bioativas (Dorozkhin, 2010). Dentre estas biocerâmicas, a hidroxiapatita (HA) e fosfato tricálcio beta $(\beta-\mathrm{TCP})$ são amplamente utilizados, pois são atóxicos, reabsorvíveis e não-inflamatórios; não causam resposta imunológica, irritação ou reação de corpo estranho (Chapard et al., 2010). Além destas características, a capacidade osteocondutora promovida pela microarquitetura porosa de sua matriz (Frenken et al., 2010), bem como seu poder osteoindutor (Li et al., 2012), levam ao seu grande uso no campo da ortopedia e cirurgia maxilofacial (Schmitt et al., 2012). No entanto, na reconstrução de grandes defeitos ósseos a baixa capacidade osteogênica deste tipo de material dificulta o ganho efetivo de tecido ósseo (Vahabi et al., 2012).

Recentemente a engenharia tecidual óssea tem sido utilizada como uma estratégia para a regeneração óssea porque pode abastecer com células e/ou mediadores o defeito, promovendo um potencial regenerativo satisfatório (Wang et al., 2009).

A medula óssea adulta contém células tronco mesenquimais que são consideradas multipotentes e que podem replicar como células indiferenciadas e que possuem potencial para se diferenciarem em linhagens de tecido mesenquimal, 
incluindo osso, cartilagem, gordura, tendão, músculo e estroma medular, e que ultimamente tem recebido ampla atenção devido a sua utilidade potencial na aplicação da bioengenharia tecidual (Pittenger et al., 1999; Wang et al., 2003). Embora existam na literatura relatos demonstrando que as células tronco mesenquimais podem ser usadas sozinhas na reparação do tecido ósseo (Lacerda et al., 2008), outros entretanto acreditam que células isoladas não podem formar novo tecido sozinhas, pois dependem de uma ancoragem e requerem um ambiente específico que inclui a presença de um material para agir como um suporte para ocorrer o crescimento (Vahabi et al., 2012).

A despeito das vantagens já conhecidas do uso do osso autógeno e das biocerâmicas, e considerando que a osteogênese resulta da ação dos osteoblastos, acreditamos que a engenharia tecidual óssea utilizando como carreador de osteoblastos a cerâmica de fosfato de cálcio bifásica composta de hidroxiapatita e fosfato tricálcio- $\beta$, associada ao osso autógeno possa ser um enxerto ósseo ideal com respeito à osteogênese, osteocondução e osteoindução. 


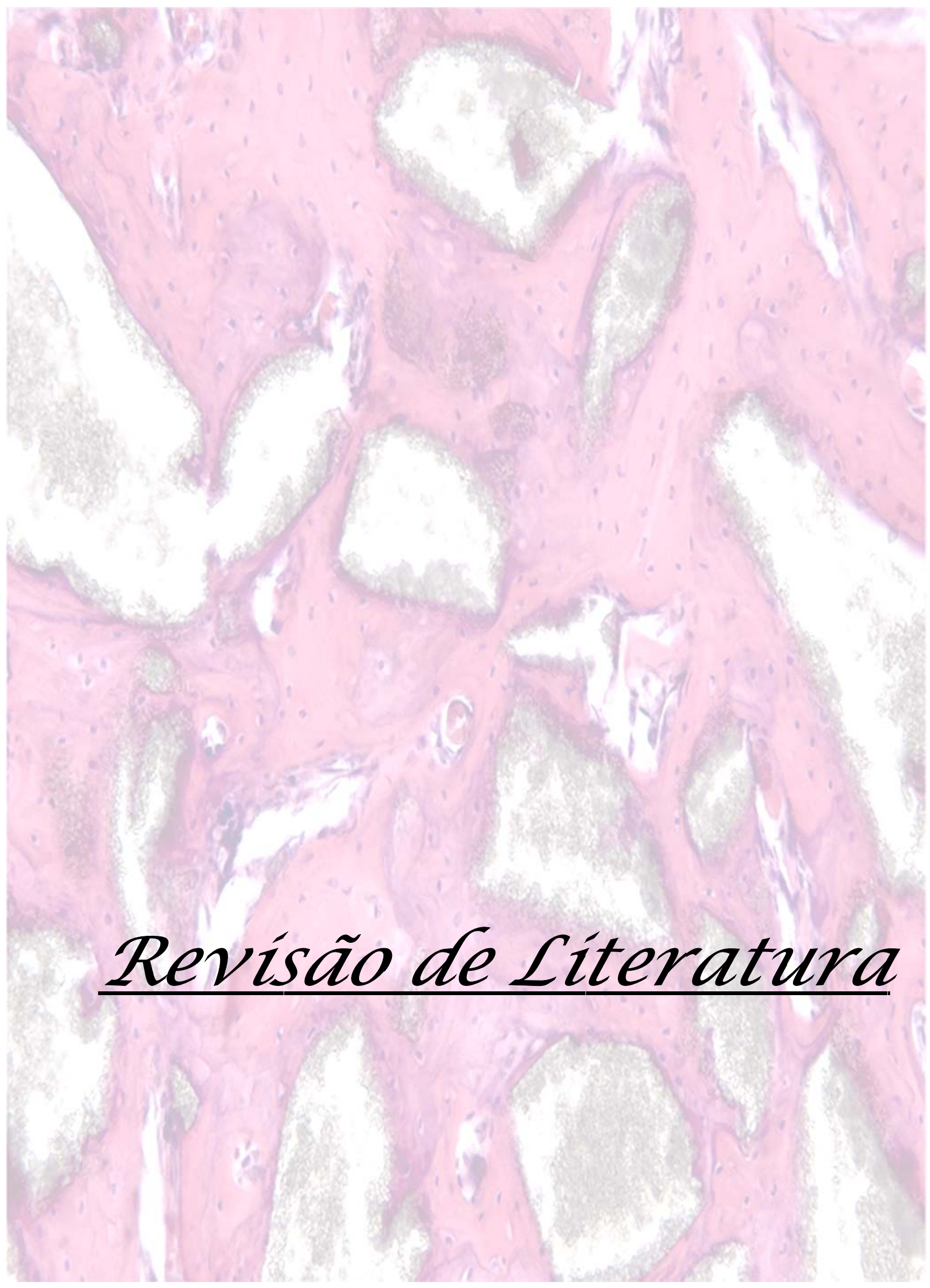




\section{Revisão da Literatura}

\subsection{REPARAÇÃO ÓSSEA}

Os estudos da reparação óssea que se segue à extração dentária, realizados em humanos e em diferentes espécies animais, descrevem a sequência de alterações celulares e tissulares, bem como a cronologia do processo, que culmina com o completo preenchimento do alvéolo dentário por tecido ósseo neoformado.

Em 1960, Amler et al. descreveram a reparação alveolar através de estudos feitos com biópsias de feridas de extração dentária humanas, como um processo que pode ser dividido nas seguintes fases: 1) logo após a exodontia ocorre a formação do coágulo; 2) em seguida ocorre a substituição do coágulo por tecido de granulação; 3) este tecido de granulação é substituído por tecido conjuntivo; 4) ocorre então a formação de um tecido osteóide, principalmente no ápice do alvéolo e depois, em toda extensão do alvéolo, partindo do ápice para região cervical; 5) amadurecimento da matriz óssea e 6) epitelização da ferida cirúrgica.

Okamoto e Russo em 1973 descreveram a reparação alveolar em ratos num período de 21 dias, em intervalos de 3 em 3 dias. Dividiram o processo em 3 fases distintas: período de formação de coágulo e proliferação de células, período de formação de tecido conjuntivo e período de ossificação. Ao final de 21 dias o alvéolo estava completamente preenchido com tecido ósseo.

Em 1987, Carvalho e Okamoto acrescentaram, ainda com finalidade didática, uma $4^{a}$ fase à reparação alveolar. A fase de maturação do tecido conjuntivo que acontece antes da fase de ossificação. 
Lin et al. (1994) em análise histológica detalhada da evolução do reparo alveolar mostra que, o coágulo sanguíneo que preenche o alvéolo imediatamente após a extração dentária, é progressivamente reabsorvido e invadido por fibroblastos derivados do ligamento periodontal residual, estes produzem fibras colágenas, que segundo Devlin e Sloan (2002), são do tipo I e III, criando assim uma fonte para a subsequente formação óssea. Estes dois trabalhos relatam ainda evidências de que, ambos os fibroblastos do ligamento periodontal e células osteoprogenitoras do osso circunvizinho são importantes para a diferenciação osteoblástica, levando assim à substituição de tecido conjuntivo por osso novo.

Lin et al. (1994), Okamoto et al. (1994) e, Kumar et al., (2005) mostram que para a adequada sucessão dos eventos reparativos, os macrófagos são essenciais, pois reabsorvem o coágulo para este tecido sofrer a maturação com a progressiva aposição de colágeno e reprodução de matriz óssea pelos osteoblastos.

Lamano-Carvalho et al. (1997) em análise histométrica, analisaram a cronologia da reparação alveolar em ratos após exodontia. Observaram que a neoformação óssea continua após 21 dias da extração dentária, tempo considerado por outros autores como final do processo. Nos resultados, até a $6^{a}$ semana (42 dias) ainda ocorre formação de tecido ósseo no terço cervical do alvéolo.

Jahangiri et al. (1998) e, Devlin e Sloan (2002), mostraram que os novos fibroblastos produzidos pela diferenciação das células progenitoras e mitoses de fibroblastos pré-existentes, sobre a influência de fatores de crescimento liberados pelas plaquetas (PDGF), sintetizam uma delicada matriz que associada à formação de novos capilares caracterizam o tecido de granulação. Este tecido conjuntivo imaturo que se forma a partir das margens do alvéolo em direção ao centro é 
gradualmente substituído por um tecido conjuntivo maduro e mais tarde por trabéculas ósseas neoformadas na mesma direção centrípeta.

Na escala molecular, a formação inicial do coágulo sanguíneo resulta da liberação de alguns fatores de crescimento, como o fator de crescimento derivado das plaquetas (PDGF), fator de crescimento semelhante à insulina (IGF), fator de crescimento tumoral $\beta$ (TGF- $\beta$ ) e fator de crescimento fibroblástico (FGF), cuja ação se dá na sinalização angiogênica e mitogênica nos estágios iniciais da reparação óssea. Com a substituição do coágulo pelas fibras colágenas, a expressão das proteínas ósseas morfogenéticas (BMPs) é aumentada e a osteogênese é iniciada (Franceschi, 2005).

O processo de mineralização do alvéolo dentário é caracterizado pela deposição de cálcio na matriz orgânica óssea, composta na sua grande parte por fibras colágenas. Além da síntese destas, os osteoblastos são capazes de sintetizar algumas proteínas não colágenas, como a osteocalcina, a osteopontina e a sialoproteína óssea, consideradas importantes no processo mineralizador ósseo (Shyng et al., 1999; De Oliveira et al., 2003;). Em ratos, a maior atividade mineralizadora pode ser observada entre o $14^{\circ}$ e o $21^{\circ}$ dias, períodos estes onde podem ser encontrados os maiores índices de marcação tecidual pela osteocalcina, diminuindo nos estágios subsequentes da reparação óssea alveolar (Rodrigues Luvizuto et al., 2010). O processo reparacional em questão se completa com a epitelização da ferida cirúrgica e remodelação da crista alveolar (Ahn e Shin, 2008).

A reparação alveolar tem sido investigada em numerosas condições experimentais, no sentido de observar possíveis fatores, locais ou sistêmicos, que possam interferir com o processo, acelerando-o ou retardando-o. 
Quanto as interferências sistêmicas no processo de reparo ósseo, Shoji et al. (2000), avaliaram as interferências da gravidez e amamentação, bem como a quantidade de Cálcio na alimentação de ratas, sobre a densidade mineral óssea alveolar. Os autores observaram que, a densidade mineral óssea alveolar diminuiu baseado na concentração de Ca na dieta, mas a magnitude desse declínio foi muito mais expressiva no grupo das ratas prenhas e amamentando do que das não prenhas.

Bombonato-Prado et al. (2004), mostraram através de análise histomorfométrica, uma menor neoformação óssea alveolar quando ratos eram submetidos a ingestão crônica de bebida alcoólica.

Gau et al. (2005), através de análise histométrica, estudou os efeitos da administração oral de ciclosporina A, no metabolismo ósseo alveolar pós-extração. Este medicamento age na supressão específica da subpopulação de células-T, utilizado principalmente pós-transplante de órgãos. Os autores observaram menor quantidade de tecido osteóide no grupo tratado com este medicamento.

Okamoto et al. (2006), estudaram o efeito da desidratação crônica no reparo alveolar. Observou-se nos ratos com hidroprivação, um coágulo desorganizado com discreto número de macrófagos e baixa quantidade de tecido conjuntivo neoformado, o que levou a um profundo atraso na substituição de tecido conjuntivo por tecido ósseo.

A deficiência de estrógeno e seus efeitos no reparo ósseo alveolar, foram estudados por Pereira et al. (2007), através da densitometria óssea e análise histométrica. As ratas ovariectomizadas mostraram nos períodos iniciais da cicatrização, um aumento no número de fibroblastos e na concentração de colágeno, e nos períodos tardios uma intensa redução na neoformação óssea. 
A deficiência de boro na alimentação e sua relação com a cicatrização óssea alveolar em ratos foi analisada por Gorustovich et al. (2008). A análise histométrica mostrou uma redução de 36 e $63 \%$ da quantidade de tecido ósseo nos períodos de 7 e 14 dias pós-extração respectivamente.

A associação de ovariectomia e administração de nicotina na capacidade de cicatrização óssea foi estudada por Machado et al. (2010). Os autores observaram que o uso da nicotina isoladamente é capaz de diminuir significativamente a capacidade de reparação óssea no alvéolo dentário, e que a deficiência de estrógeno potencializa tal efeito.

Aguirre et al. (2010) analisaram o processo de reparação óssea em alvéolos dentais de ratos submetidos à administração sistêmica de alendronato. $O$ alendronato é um medicamento antirreabsortivo da classe dos bifosfonatos, utilizado para o tratamento da osteoporose, e seu uso pode estar associado ao desenvolvimento das osteonecroses dos maxilares. Os autores observaram que o uso deste fármaco levou a uma diminuição da neovascularização e da neoformação óssea no interior do alvéolo dentário.

Os efeitos do café no metabolismo ósseo de ratos foram estudados por Lacerda et al. em (2010) através de análises bioquímicas, densitométrica e histométrica. Os autores observaram um aumento no cálcio plasmático e urinário, e diminuição da ordem de $30 \%$ da capacidade de neoformação óssea no alvéolo dentário. Concluíram que o uso crônico do café em ratos é capaz de alterar o metabolismo do cálcio e refletir na densidade mineral e na habilidade reparacional do tecido ósseo.

Macedo et al. (2011) também demonstraram que a administração crônica de cafeína intraperitonealmente foi capaz de diminuir a quantidade de osso no interior 
do alvéolo dentário de ratos. Os resultados revelaram que grandes quantidades de coágulo sanguíneo estavam presentes até nos períodos mais tardios (42 dias) e menor quantidade de tecido ósseo neoformado $(32,0 \%)$ nos animais tratados com cafeína quando comparados ao controle.

Teófilo et al. (2011) estudaram a influência da nimesulida no processo de reparação óssea alveolar em ratos. $\mathrm{O}$ tratamento com o antiinflamatório foi iniciado no dia da extração dentária e continuou por mais 2 semanas. Os autores concluíram que o uso da nimesulida por este período não demonstrou diferenças estatisticamente significantes na porcentagem de tecido ósseo neoformado em comparação aos animais controles.

Macedo et al. (2012) estudaram as alterações causadas pela osteoporose e o uso crônico de cafeína no processo de reparo alveolar de ratos. Os resultados demonstraram que houve uma diminuição de $41,0 \%$, para os animais castrados (simulação do quadro osteoporótico) e de $61,0 \%$ para os animais castrados e com uso crônico de cafeína em relação ao controle. Concluíram os autores que, a castração/osteoporose causa um retardo na capacidade cicatrizadora óssea nos alvéolos dentais e que este quadro é exacerbado pelo uso concomitante da cafeína.

Quanto as interferências locais no processo de reparo ósseo, Magalhães et al. (1982), afirma que a irregularidade no contorno e altura do alvéolo e a fratura da tábua óssea ou de cristas alveolares durante a exodontia, atrasam a reparação normal.

Para Carvalho e Okamoto (1987), a laceração da gengiva, o diâmetro aumentado do alvéolo, a permanência de fragmentos ósseos sem nutrição, resíduos radiculares e de corpos estranhos no interior do alvéolo, retardam o processo de reparação normal. Além disso, cuidados com a curetagem, irrigação e suturas do 
defeito, doenças periodontais prévias e às infecções, como alveolites, também são prejudiciais no pós-operatório.

Em 1994, Okamoto et al. avaliaram a importância da permanência do coágulo no interior do alvéolo. No estudo, em um grupo de animais as bordas do alvéolo foram suturadas logo após a exodontia, e em outro o coágulo foi removido após 6 a 8 minutos da cirurgia. Houve atraso na cicatrização no $2^{\circ}$ grupo e, embora um novo coágulo tenha sido formado, este não era organizado. Desta forma, concluíram que a qualidade, constituição, manutenção e retração do coágulo são fatores que regulam a formação de tecido conjuntivo durante a reparação alveolar.

Numa revisão realizada por Carvalho e Okamoto (1978), verificou-se que a maioria dos implantes atrasa o processo de reparação. A justificativa empregada é a de que a presença de qualquer material estranho no interior do alvéolo perturbaria a organização do coágulo e provocaria distúrbios na neoformação tecidual, atrasando a cronologia da reparação.

O material pode se comportar como agente irritante, sendo reconhecido como corpo estranho, por isso o organismo tenta eliminá-lo. Isso ocorre também devido à maior irrigação sanguínea das estruturas da cavidade bucal, o que determina maior defesa local e reações mais severas contra corpos estranhos (Carvalho e Okamoto, 1987).

Apesar disso, numerosos trabalhos foram desenvolvidos com a aplicação (implante/enxerto) local de materiais na busca de um material que promova formação óssea em tempo curto. Estes materiais são chamados de biomateriais, e podem ser definidos como uma substância ou combinação de duas ou mais substâncias farmacologicamente inertes, de natureza sintética ou natural, que são utilizados para melhorar, aumentar ou substituir, parcial ou integralmente, tecido e 
órgãos (Williams, 1987), sendo fabricadas pela engenharia para dar forma e na qual, sozinha ou como parte de um sistema complexo, é usada para direcionar o curso de algum procedimento trapêutico ou diagnóstico, pelo controle das interações com componentes dos sistemas vivos em medicina humana ou veterinária" (Williams, 2009)..

Bombonato-Prado (2002) avaliou qualitativa e quantitativamente através de microscopia de luz e eletrônica de varredura, os efeitos de uma bebida alcoólica na reparação alveolar, comparando, nesta situação, a ação de uma biocerâmica de fosfato de cálcio (Osteosynt) na neoformação óssea. Concluíram que a utilização da biocerâmica minimiza os efeitos deletérios do alcoolismo crônico sobre a reparação alveolar.

Em 2005, Calixto examinou o comportamento de enxertos ósseos heterógenos orgânico e inorgânico (Matriz Óssea Bovina Liofilizada Orgânica e Inorgânica), de uma mistura de BMPs (Proteínas morfogenéticas do osso) bovinas e de um vidro bioativo implantados no interior do alvéolo. Concluiu que qualquer material introduzido no interior de um defeito pode atrasar a reparação. Portanto, segundo o autor, deve-se ponderar em quais circunstâncias um determinado material favoreceria o resultado desejado.

Também, o látex, na forma de grânulos e gel associado ao colágeno, foi avaliado no interior do alvéolo de ratos, em períodos de 7, 21 e 42 dias, por Balabanian (2005). Dos resultados concluiu-se que o látex é um material biologicamente biocompatível, desenvolvendo uma osteointegração progressiva, estimulando a angiogênese e acelerando a neoformação óssea nos primeiros 7 dias da reparação óssea. 
Em 2006, Castro avaliou o comportamento do enxerto de composto ósseo de rícino (C.O.R.) em alvéolos dentais e sua eficácia na manutenção do rebordo alveolar em ratos. O C.O.R. é um material aloplástico de origem vegetal derivado do óleo de mamona, cuja fórmula molecular tem mostrado certa compatibilidade com tecidos vivos e propriedades osteocondutivas. As análises radiográficas e histológicas mostraram que este composto, quando implantado em alvéolos dentais de ratos, é capaz de manter as dimensões do rebordo alveolar, mais eficazmente que os animais controle.

Calixto et al. (2007) estudaram o enxerto em alvéolos dentais de proteínas morfogenéticas do osso (BMPs), associadas a um carreador de hidroxiapatita microgranular e colágeno bovino. As BMPs são proteínas consideradas capazes de promover a osteoindução, ou seja, a diferenciação de células mesenquimais indiferenciadas em osteoblastos, e estes produzirem o tecido ósseo. Os resultados mostraram um padrão normal de cicatrização óssea igualmente para os enxertados e controles.

Garcia em 2007 avaliou comparativamente, os fenômenos evolutivos do processo de reparo em alvéolos de ratos preenchidos com osso medular bovino inorgânico e hidroxiapatita/ $\beta$-TCP densa. Os parâmetros analisados foram: infiltrado inflamatório, densidade fibroblástica, densidade angioblástica e neoformação óssea. As análises qualitativa e quantitativa mostraram que a hidroxiapatita $\beta$-TCP densa apresenta características satisfatórias como biomaterial osteocondutor e osteopreenchedor, e quando comparada ao osso bovino inorgânico, os dois materiais obtiveram o mesmo desempenho no processo de reparo alveolar.

Wu et al. (2008) analisaram os efeitos da sinvastatina, (antihipercolesterolemia), associado com um carreador de ácido polilático-glicólico 
(PLGA), implantados em alvéolos dentais de ratos. Os efeitos da associação medicamento-carreador foram estudados histologicamente, através da densidade mineral óssea e de medidas da reabsorção do osso alveolar pós- extração. Os resultados mostraram que a altura relativa do rebordo alveolar residual e a densidade mineral óssea foram significativamente maiores no grupo experimental quando comparado aos controles.

A implantação de hialuronato de sódio no interior do alvéolo dentário de ratos foi estudado por Mendes et al. (2008). O hialuronato de sódio, ou ácido hialurônico é uma glicosaminoglicana de alto peso molecular constituinte da matriz extracelular tendo uma importante função na morfogênese e na reparação tecidual. As análises através da histomorfometria e expressão imunohistoquímica de BMP-2 e osteopontina demonstraram uma deposição óssea trabecular mais precoce nos animais tratados com o hialuronato, maior porcentagem de osso no terço apical e aumento da expressão de BMP-2 e osteopontina nos tecidos quando comparados ao controle.

Em análise recente, Ahn e Shin (2008) verificaram em humanos a formação óssea ao longo do tempo em alvéolos dentais com doença periodontal avançada e saudáveis. Os principais achados foram que a reparação óssea nos alvéolos doentes periodontalmente é mais lenta, complicada e imprevisível que nos sem doença, de modo que a porcentagem de $50,0 \%$ de novo tecido ósseo é alcançada nos defeitos ósseos com periodontite apenas na $16^{a}$ semana, ao passo que nos saudáveis este número é conseguido em 8 semanas.

O fosfato tricálcio beta ( $\beta$-TCP) foi avaliado por Horowitz et al. (2009) em humanos como um substituto ósseo para manter as dimensões alveolares para um futuro tratamento com implantes As dimensões alveolares eram mensuradas antes 
da enxertia e após 6 meses, bem como uma amostra tecidual era coletada antes da colocação do implante. Os autores puderam observar que houve uma diminuição das dimensões alveolares de apenas 9,0\% quando comparado ao pré-operatório, e histologicamente todo o material foi reabsorvido e substituído por osso vital de boa qualidade que permitiu um bom travamento dos implantes dentais.

Com os avanços da terapêutica molecular regenerativa óssea, McAllister et al. (2010) analisaram o uso do fator de crescimento derivado das plaquetas recombinante humano (rh-PDGF) na capacidade regenerativa alveolar pós-extração em humanos. Foram utilizados dois substitutos ósseos como carreador deste fator de crescimento, o fosfato tricálcio $\beta$ (Gem21 - Osteohealth) e o BioOss Collagen (Geistlich). O PDGF foi adicionado a estes dois biomateriais e implantado em alvéolos dentais humanos que após um período de 3 meses foram analisados clínico e histomorfometricamente. Histologicamente pode ser observado semelhantes resultados em relação à quantidade de osso vital para ambos os grupos, e clinicamente adequada preservação alveolar pós-exodontia com alta taxa de sucesso dos implantes instalados na área.

Ainda em relação à expressão dos fatores de crescimento, Reis-Filho et al. (2012) avaliou a influência do enxerto de matriz dentinária humana desmineralizada (DHDM) na neoformação óssea e na expressão do fator de crescimento vascularendotelial (VEGF) em alvéolos dentais de ratos. Os animais tiveram os molares superiores extraídos onde o lado esquerdo foi preenchido com a DHDM e o direito apenas com o coágulo sanguíneo, procedendo-se a análise morfométrica e imunohistomquímica aos 3, 7, 14 e 21 dias. Os resultados demonstraram que o material foi capaz de promover um significante aumento no tecido ósseo neoformado no $7^{\circ}, 14^{\circ}$ e $21^{\circ}$ dias e na expressão do VEGF no $7^{\circ}$ e $14^{\circ}$ dia pós exodontia. Os 
autores concluíram que a matriz dentinária humana desmineralizada acelera o processo de reparação pela estimulação da deposição óssea e formação vascular, sendo, portanto um adequado material com propriedades osteocondutivas e osteoindutivas.

Nahles et al. (2012), investigaram e compararam o potencial osteogênico com a vascularização na matriz óssea de alvéolos dentais humanos com ou sem procedimento de enxertia, utilizando marcações imunohistoquímicas para Cbfa1/Runx2, Osteocalcina e CD31 realizadas em 4 e 12 semanas. Um grupo de pacientes recebeu o preenchimento com BioOss Collagen (Geistlich) no alvéolo e o outro apenas o coágulo sanguíneo. Os experimentos evidenciaram que a atividade osteoblástica e o comportamento angiogênico é mais alta em 4 semanas principalmente no terço apical, e em 12 semanas no terço cervical, mas a medida que o processo de reparo ósseo vai se completando as células ativas vão diminuindo ao passo que aumenta as que estão em estado inativo. Quanto à presença ou não do material de enxerto intra-alveolar, nenhum efeito inibitório sobre as células endoteliais e na atividade angiogênica pode ser constatado em 4 e 12 semanas.

Avaliações clínicas e histológicas do uso do sulfato de cálcio hemihidratado de uso médico (MGCSH) associado ao plasma rico em plaquetas (PRP) em alvéolos dentais humanos foram realizadas por Kutkut et al. (2012). Em um grupo a associação MGCSH + PRP foi implantada no defeito ósseo pós-extração e em outro uma esponja absorvível de colágeno + PRP (controle), que se seguiu pelas análises das dimensões alveolares antes e após 3 meses, bem como dos achados histomorfométricos. Os achados experimentais demonstraram que a porcentagem de osso vital neoformado após 3 meses foi de $66,5 \%$ para o grupo MGCSH 
comparado aos $38,3 \%$ para o controle, e em relação as dimensões alveolares não houve diferenças estatisticamente significantes. Assim concluem que a associação MGCSH + PRP é capaz de produzir grande quantidade de tecido ósseo neoformado em uma velocidade maior comparativamente aos controles.

Morjaria et al. (2012) em um revisão de literatura avaliaram o processo de reparo ósseo alveolar pós extração com ou sem o emprego de materiais de enxerto ou membranas. Concluíram que existem dados limitados em relação à efetividade das terapias de preservação alveolar comparados aos controles, mas que de forma geral, as intervenções nos alvéolos pós-extração são capazes de diminuir as alterações dimensionais nos rebordos alveolares. 


\subsection{OSSO AUTÓGENO}

A enxertia de tecido ósseo é um procedimento muito antigo. O primeiro registro do uso deste tipo de enxerto é datado de 1668, quando esta técnica era utilizada a fim de solucionar problemas relacionados à má cicatrização óssea como a não consolidação de fraturas, a consolidação óssea tardia, as pseudoartroses congênitas, os defeitos ósseos pós-traumatismos, as infecções e os tumores (Chapman e Rodrigo, 2001).

Os enxertos podem ser classificados de acordo com a sua natureza e denominados conforme a terminologia moderna em: enxertos autógenos quando a origem é o próprio indivíduo; alógenos ou homógenos quando originado de indivíduo da mesma espécie, porém com características genéticas diferentes; isógenos quando oriundos de indivíduos geneticamente idênticos; heterógenos ou xenógenos quando advindos de indivíduos de espécies diferentes e aloplásticos quando são de origem sintética (Lindhe et al., 2005).

A formação de um novo osso pode ocorrer através de três diferentes processos: osteogênese, osteoindução e osteocondução, que são consideradas como as características ideais de um material de enxerto ósseo (Moore et al., 2001).

Osteogênese é definida como nova formação óssea pela existência predominante de células osteoprogenitoras diferenciadas ou osteoblastos presentes dentro do material de enxerto (Suh et al., 2001). Dessa forma um enxerto osteogênico é derivado de tecido ósseo de um local diferente do sítio receptor. Células osteogênicas podem favorecer a formação óssea em tecidos moles ou ativarem rapidamente o crescimento ósseo em sítios com presença do tecido ósseo, ou seja, ocorre a transferência de células viáveis do enxerto para o leito receptor. 
Assim o osso esponjoso, cuja superfície possui maior área coberta por células, tem um maior potencial de osteogênese quando comparado ao osso cortical (Goldberg e Stevenson, 1993).

Osteoindução tem sido definida como um possível mecanismo de regeneração óssea que envolve formação de novo osso pelas células osteoprogenitoras derivadas das células mesenquimais, sobre a influência das proteínas ósseas morfogenéticas (BMPs) isoladas da matriz óssea (Wozney, 1995) ou pela própria matriz óssea (Urist, 1965; Urist et al., 1979).

Osteocondução é o mais conhecido processo de reparação óssea porque os implantes osteopreenchedores agem como um suporte para o crescimento do osso e é substituído pelo osso novo (Dupoirieux et al., 1994). Este processo não forma, mas sustenta um meio favorável, ou seja, um arcabouço capaz de guiar as células envolvidas no processo de reparo, promovendo a angiogênese e a deposição de novo osso. Estes materiais, entretanto, são incapazes de induzir à formação óssea ectópica como ocorre com os enxertos osteoindutores.

O enxerto de osso autógeno é o procedimento cirúrgico mais comumente utilizado diante da necessidade de reconstrução de defeitos ósseos. Enquanto o emprego de enxertos autógenos mostra vantagens em relação às demais técnicas no que se refere à biocompatibilidade e ao potencial regenerador ósseo (Boyne, 1999), a experiência clínica e trabalhos experimentais mostram limitações quanto ao ganho efetivo de volume ósseo ao longo do tempo, especialmente com os enxertos “onlay” (Salata et al., 2002) e em alvéolos pós-extração (Araújo e Lindhe, 2011). Tais dificuldades têm levado muitos autores a concentrar seus estudos em fatores que podem influenciar a sobrevivência e a manutenção volumétrica dos enxertos autógenos em longo prazo (Ozaki e Buchman, 1998; Carvalho et al., 2000; Palecks 
et al., 2004). Segundo estes estudos a arquitetura interna do enxerto; sua origem embrionária; orientação de aplicação "inlay" ou "onlay"; presença do periósteo no enxerto; tratamento do leito receptor; taxa de revascularização e; métodos de fixação do enxerto no leito receptor parecem participar decisivamente para o sucesso da técnica.

Por muitos anos o osso autógeno de locais intra e extraorais é considerado a referência "gold standard" como enxerto ósseo (Minichetti et al., 2004; Jensen et al., 2006, Misch et al., 2011; Chen et al., 2011; Miyamoto et al., 2012; Schimitt et al., 2012), devido as suas vantagens biológicas e potencial osteogênico (Sanada et al., 2003; Macedo et al., 2011), atuando por osteoindução e osteocondução (Ellies, 1992), promovendo estímulo e aposição de tecido ósseo a partir do osso já existente, como modelo para a neoformação óssea (Manso e Lang, 1997; Misch et al., 2011). Contendo em sua matriz inorgânica, osteócitos, osteoclastos, osteoblastos e proteínas osteogênicas, o osso autógeno apresenta potencial para osteogênese quando usado como enxerto para melhorar ou corrigir defeitos ósseos (Misch et al., 2011; Chen et al., 2011). O seu uso na reconstrução de defeitos se deve ao fato de não causar reações imunogênicas, por conter células capazes de se diferenciarem em osteoblastos (Yoshikawa et al., 2004), capacidade indutora de fatores de crescimento constituída por uma matriz osteocondutiva bioreabsorvível que age como fonte para a angiogênese, infiltração celular, formação de cartilagem e deposição de tecido calcificado (Orr et al., 2001; Macedo et al., 2011).

Entretanto a utilização de osso autógeno como material de enxerto causa certo grau de morbidade ao indivíduo, já que é necessário um sítio cirúrgico adicional para a obtenção do enxerto. Além disso, o desconforto pós-operatório do 
paciente e o risco de infecção do local são aumentados (Cordaro et al., 2010; Barone et al., 2011; Touzet et al., 2011).

A escolha do local doador dependerá da quantidade de volume ósseo necessário para restabelecer o contorno original do processo alveolar reabsorvido. Os possíveis locais para coleta do enxerto envolvem sítios cirúrgicos intra ou extraorais. As áreas intraorais mais comumente utilizadas para a remoção do enxerto ósseo são as regiões do mento, margem anterior do ramo da mandíbula e tuberosidade maxilar. As áreas extraorais utilizadas como doadoras de tecido ósseo englobam a crista ilíaca, a calvária, a tíbia e as costelas (Dinato e Polido, 2004).

Peer (1951) foi o primeiro autor a sugerir que a diferença de histogênese dos enxertos poderia alterar sua incorporação. Observou que os enxertos de ossificação intramembranosa teriam reabsorção menor que os outros. O autor colocava ossos nasais, vômer e parte dos ossos etmoidais oriundos de ressecções de dorso nasal de pacientes, em contato com tecido não ósseo (abdômen). Observou dois anos e meio após, que o osso colocado no abdômen apresentava células ósseas viáveis, enquanto os enxertos oriundos da costela, da tíbia e da crista ilíaca se reabsorviam totalmente. O autor explicou que, possivelmente, as células dos enxertos corticais de origem embriológica membranosa teriam menor poder de regeneração, porém maior habilidade de reter sua matriz calcificada, apesar do contato com o osso.

Vários trabalhos têm mostrado a superioridade dos enxertos de origem intramembranosa, como os da calota craniana, quando comparados aos de origem endocondral, tíbia e crista ilíaca, nas cirurgias reconstrutivas craniomaxilofaciais, (Ozaki e Buchman et al., 1998; Iturriaga e Ruiz, 2004; Carinci et al., 2005; Salvato e Agliardi, 2007; Gutta et al., 2009; Bastos et al., 2012; Deppe et al., 2012) pois são 
pouco reabsorvidos e apresentam maior neoformação óssea, aliados a uma menor morbidade em relação ao procedimento cirúrgico.

Por essas e outras características peculiares ao osso autógeno, várias pesquisas tem sido realizadas a fim de compará-lo aos diversos tipos de materiais substitutos do tecido ósseo.

Orsini et al. (2001), testaram e compararam o uso de duas combinações de materiais para tratamento de defeitos intraósseos periodontais: osso autógeno com sulfato de cálcio e osso autógeno com membrana reabsorvível. Os autores observaram a profundidade de sondagem, nível clínico de inserção e sangramento durante a sondagem durante 6 meses. Concluíram que as duas terapias foram compatíveis nos resultados.

Donos et al. (2002) também avaliaram a utilização de membranas em combinação com osso cortical autógeno, mas neste trabalho foram usadas membranas não reabsorvíveis. A intenção do uso destes materiais foi conseguir um aumento do rebordo em ratos. Os autores fizeram análise histológica em material conseguido 15, 30, 60 e 90 dias após a cirurgia. Dos resultados concluiu-se que o volume do enxerto de osso autógeno pode ser mantido com a cobertura de uma membrana, quando esta estiver apropriadamente adaptada e coberta com mucosa durante a cicatrização. Nos animais onde isto não ocorreu, osso autógeno implantado apresentou reabsorções e falta de continuidade entre o enxerto e osso do sítio receptor.

Já Tadjoedin et al. (2002), comparam o osso autógeno com um vidro bioativo (BG) em relação a capacidade destes em promover aumento do osso maxilar no assoalho do seio em humanos. Estes materiais foram testados em 3 pacientes nos dois lados da maxila. De um lado foi colocada uma mistura de $80-100 \%$ de BG com 
$20-0 \%$ de partículas de osso da crista ilíaca. Do outro lado $100 \%$ de osso autógeno foi utilizado como enxerto. As biópsias foram feitas depois de 4, 6 e 15 meses após as cirurgias. Os resultados sugeriram que uma mistura com $80-90 \%$ de BG com 10 $20 \%$ de osso autógeno são efetivos na reparação óssea para aumento do assoalho de seio, necessitando de 6 meses para cicatrização, enquanto que 12 meses são necessários para cicatrização com osso autógeno somente.

Em um trabalho realizado por Cochran et al. (2003) uma associação de osso autógeno e emdogain foi usada em defeitos ósseos de 1 a $6 \mathrm{~mm}$ criados ao lado de dentes na mandíbula de macacos. Os autores observaram, depois de 2 meses, a formação óssea e a de cemento. Concluíram que a associação dos materiais produziu maior quantidade de formação dos dois tecidos analisados, quando comparada com a utilização somente de emdogain. Vale ressaltar ainda que estes resultados foram melhores nos defeitos menores.

Em 2004, Wiltfang et al. analisou os efeitos da associação do plasma rico em plaquetas (PRP) com o osso autógeno e com outros biomateriais em defeitos críticos na calvária de miniporcos. Os defeitos foram preenchidos com osso autógeno, cerâmica de fosfato-tricálcio degradável (CeraSorb), matriz óssea bovina (Bio-Oss) e colágeno bovino (Colloss) associados ou não ao PRP, e os animais foram sacrificados depois de 2, 4 e 12 semanas. Os autores observaram que o PRP foi capaz de promover aumento na cicatrização óssea apenas quando associado ao osso autógeno e não aos outros biomateriais, e que sua ação se dá apenas nos estágios iniciais da reparação óssea.

Segundo Khan et al. (2005) a incorporação do enxerto de osso autógeno na área receptora depende de vários fatores, como: tipo de enxerto (vascular ou avascular), local do sítio doador, qualidade do osso transplantado e do osso 
receptor, preparação da área receptora, doenças locais e sistêmicas e propriedades mecânicas do enxerto.

Zijderveld et al. (2005) estudou em humanos o uso do osso autógeno comparado ao fosfato tricálcio $-\beta$ em cirurgias de levantamento de seio maxilar. Os autores concluíram que o enxerto de osso autógeno ainda é o padrão ouro na substituição e reconstrução óssea, mas que o uso limitado do fosfato tricálcio- $\beta$ mostrou ser um procedimento clinicamente seguro nestas cirurgias.

Silva e Camilli (2006) estudaram o uso do osso autógeno associado ao laser de baixa potência em defeitos na calvária de ratos. Os estudos mostraram que o uso combinado de osso autógeno com a laserterapia estimulou a osteogênese durante os períodos iniciais do processo cicatricial e que a magnitude do reparo ósseo foi dependente da dose irradiada.

O osso autógeno foi comparado através de análise histológica e histomorfométrica, a 2 materiais usados em cirurgias ortopédicas e orais, por Jensen et al. (2006). Três defeitos ósseos foram realizados no ângulo mandibular de miniporcos e preenchidos com osso autógeno, osso bovino inorgânico e fosfato tricálcio- $\beta$. Os autores observaram que em 2 semanas, osso autógeno apresentou maior neoformação óssea quando comparados aos outros 2 biomateriais, em 8 semanas não se encontrou diferenças no percentual ósseo comparado ao fosfato tricálcio- $\beta$, mas um menor valor foi observado nos defeitos preenchidos com osso bovino inorgânico. Do exposto concluem que, o osso bovino inorgânico e o fosfato tricálcio- $\beta$ desaceleram a regeneração óssea nas fases iniciais do reparo, quando comparados ao osso autógeno, mas apresentam boa integração ao osso, e foram capazes de promover a cicatrização do mesmo. 
Em 2007 um estudo realizado no nosso laboratório, Prata et al. avaliaram histológico e histometricamente, o comportamento do reparo ósseo alveolar, utilizando como material de enxerto intra-alveolar osso autógeno e proteínas derivadas da matriz do esmalte. Os pesquisadores puderam concluir em seus resultados que os fragmentos de osso autógeno desenvolveram progressiva osteointegração e não sofreram reação de corpo estranho. Também comprovaram que a fração de volume de osso trabecular adjacente ao enxerto, foi de 10 a $15 \%$ maior no grupo que recebeu osso autógeno associado a proteínas derivadas da matriz do esmalte do que no grupo que recebeu apenas o osso autógeno.

Neste mesmo ano (2007), Melo investigou a influência do osso autógeno particulado retirado da crista ilíaca no processo de reparo ósseo alveolar em ratos. Os dados obtidos foram analisados estatisticamente e mostraram que houve um aumento progressivo da densidade de área ocupada por osso em função dos tempos pós-operatórios e a morfometria da densidade da área ocupada por osso nos grupos controle e experimental não apresentaram diferenças estatísticas em nenhum dos tempos pós-operatórios. Assim o autor conclui que o osso autógeno não promoveu um aumento estatisticamente significante na neoformação óssea em alvéolos dentais de ratos nos períodos estudados.

A capacidade de integração e reparação óssea dos enxertos de osso autógeno em ratas com deficiência estrogênica foi estudada por Luize et al. (2008). Após um período de 30 dias da castração dos animais, um enxerto ósseo autógeno tendo como área doadora a calota craniana foi retirado e fixado ao ângulo mandibular. Os animais foram sacrificados em 7, 14 e 28 dias após o procedimento de enxertia para análise histomorfométrica. Os resultados mostraram que em 28 dias o enxerto do grupo controle estava aparentemente integrado à mandíbula, enquanto 
no grupo de ratas castradas a interface enxerto-sítio receptor estava parcialmente preenchida por tecido ósseo neoformado com áreas de tecido conjuntivo interposicional, revelando uma taxa de neoformação óssea de 57,41\% contra $40,82 \%$ respectivamente. Concluíram os autores que a depleção estrogênica retardou o processo de reparo ósseo dos enxertos autógenos em mandíbulas de ratas.

Yilmaz et al. (2010) avaliaram os benefícios da cirurgia periodontal regenerativa usando uma combinação proteína derivada da matriz do esmalte (Emdogain) e osso autógeno. O protocolo experimental consistiu na realização das medidas clínicas do nível de inserção clínica antes da terapia e após 1 ano. Os autores puderam concluir que as duas terapias resultaram em melhoras clínicas estatisticamente significante comparadas ao início do tratamento, mas o Emdogain quando associado ao osso autógeno da região retromolar promoveu resultados mais promissores quanto ao aspecto clínico dos tecidos mole e duro periodontal.

Em um trabalho desenvolvido pelo nosso grupo de pesquisa em 2011, Macedo et al. analisaram a capacidade de osteointegração do osso autógeno (OA) associado a células tronco diferenciadas em células osteoblásticas (CO) em ratos sob tratamento crônico com cafeína. Um fragmento ósseo retirado da calota craniana foi triturado e inserido no alvéolo dentário dos animais juntamente com o pool de células, e após períodos de 7, 21 e 42 dias análises histológicas e histométrica foram realizadas. Concluiu-se que a combinação de $\mathrm{OA}+\mathrm{CO}$ implantada em defeitos ósseos após a extração dentária de ratos sobre tratamento com cafeína foi biocompatível, não apresentou reações imunes, e foi capaz de compensar os efeitos deletérios causados por esta droga no processo de reparação óssea e osteointegração. 
Estudos em humanos e animais têm mostrado que após a remoção do elemento dentário, o rebordo alveolar neste local começa a se tornar marcadamente reduzido pela remodelação óssea, assim Araújo e Lindhe (2011) examinaram se o enxerto de osso autógeno particulado intra-alveolar seria capaz de conservar as dimensões ósseas para a futura instalação de implantes. O estudo foi realizado em cães, onde os alvéolos das raízes distais do $3^{\circ}$ e $4^{\circ}$ pré-molar foram removidos e os alvéolos foram preenchidos de um lado com osso autógeno do ramo mandibular e do outro com osso bovino inorgânico (BioOss Colagen). Após um período experimental de 3 meses os autores puderam observar histologicamente que a maioria das partículas do osso autógeno tinha sido reabsorvida e que este material não interferiu nos processos de reparo e remodelação alveolar quando comparado ao BioOss Collagen.

Chen et al. (2011) averiguaram a resposta biológica do osso autógeno particulado e malha de titânio para a reconstrução óssea de defeitos segmentares em mandíbula de cães, e também na osseointegração de implantes dentais. Um defeito unilateral de $40 \mathrm{~mm}$ de comprimento foi realizado nos animais e em seguida parte do osso removido da mandíbula foi triturado e misturado com osso da crista ilíaca, totalizando uma mistura de osso cortical e esponjoso de 3:1. Dois implantes foram instalados no meio do enxerto ósseo simultaneamente ao procedimento reconstrutivo. Após 6 meses, análises radiográfica, histológica, de microscopia eletrônica de varredura e de espectroscopia dispersiva de energia foram realizadas. Os resultados demonstraram que o osso autógeno particulado associado à malha de titânio é um método viável para a reconstrução de defeitos segmentares de mandíbula, e que os implantes instalados imediatamente possuíam ótima qualidade histológica do osso neoformado na sua vizinhança. 
A regeneração óssea em alvéolos dentais de gatos após a enxertia com osso autógeno da crista ilíaca foi estudado por Silva et al. (2012). Os animais tiveram o canino inferior direito removido e posteriormente, de acordo com o preenchimento do alvéolo, foram divididos em três grupos: controle, em que o alvéolo foi preenchido apenas com o coágulo sanguíneo; osso autógeno cortical em raspas e osso autógeno esponjoso. Através das análises radiográficas e histomorfométricas pode ser constatado que os alvéolos dentais preenchidos tanto com o osso autógeno esponjoso ou cortical apresentaram regeneração óssea similar aos animais do grupo controle.

Em 2012, Miyamoto et al. também avaliaram a qualidade e a quantidade óssea das reconstruções mandibulares em humanos utilizando o osso autógeno particulado e malha de titânio. Após um período de 6 meses, os resultados obtidos em tomografias e histologia dos 41 pacientes operados pode demonstrar que o osso autógeno particulado associado a malha de titânio e' um ferramenta adequada para reconstruções ósseas verticais e horizontais em mandíbula. 


\subsection{CÉLULAS TRONCO}

\subsubsection{Conceitos, Origens, Definições e Propriedades}

Os diferentes órgãos dos seres vivos mais evoluídos (eucariotos) são formados por tecidos diferenciados que exercem atividades especializadas. Apesar da grande diversidade de células que podem ser reconhecidas em tecidos adultos, todas derivam de uma única célula-ovo, após a fecundação de um óvulo por um espermatozóide. Essa única célula tem, pois, a propriedade de formar todos os tecidos do indivíduo adulto. Inicialmente, essa célula totipotente divide-se formando células idênticas, mas, muito precocemente na formação do embrião, os diferentes grupos celulares vão adquirindo características especializadas e, ao mesmo tempo, vão restringindo sua capacidade de diferenciação). No entanto, na maioria dos tecidos adultos existem reservas de células com capacidade de multiplicar-se, diferenciando-se naquele tecido a que pertencem e ao mesmo tempo mantendo esta própria reserva de células indiferenciadas. Essas células tronco tecido-específicas são as responsáveis pela manutenção da integridade dos tecidos adultos, pelo reparo de tecidos lesados e pela remodelação dos tecidos e órgãos. Essas células progenitoras capazes de diferenciar-se em tecidos adultos especializados são denominadas células tronco. As células tronco são um tipo de células indiferenciadas, sem função específica nos tecidos, capazes de multiplicar-se mantendo-se indiferenciadas por longos períodos (tanto in vitro como in vivo), mas que diante de estímulos específicos podem diferenciar-se em células maduras e funcionais dos tecidos, ou seja são capazes de se auto renovarem e dar origem a células especializadas. (Zago e Covas, 2006). 
Estas células são quiescentes, i.e. se mantêm por longo período de tempo na fase $G_{0}$ do ciclo celular, e possuem duas propriedades fundamentais: são capazes de se auto renovarem e de realizar divisões celulares assimétricas. Em essência as células tronco quando ativadas por algum sinal ou evento podem deixar seu estado de repouso e avançar no ciclo celular, dando origem a 2 tipos celulares diferentes, o que é conhecido como divisão celular assimétrica. Um tipo celular mantém as características da célula-mãe permanecendo indiferenciadas, repondo o pool de células tronco local, propriedade esta conhecida como auto renovação. O outro tipo celular se prolifera por divisão simétrica dando origem as células progenitoras, que têm a capacidade de se diferenciarem em células especializadas, como osteoblastos, formando tecidos maduros (Muschler e Midura, 2003; Zago e Covas, 2006).

A auto renovação desempenha um importante papel, pois se todas as células tronco se tornassem células diferenciadas, a população das mesmas diminuiria progressivamente a partir de cada evento de ativação, o que levaria ao rápido esgotamento da população destas células em todos os tecidos normais, resultando em um número insuficiente para suportar os processos de remodelação e reparo necessários para a manutenção em longo prazo da saúde do organismo (Lin, 1998).

As células tronco e as células progenitoras estão presentes em praticamente todos os tecidos humanos normais e são fundamentais para sua saúde, manutenção e resposta a lesões ou doenças durante a vida. De acordo com Bianco et al. (2001), estas células são a fonte de todos os tecidos novos formados pelos sistemas de reparo e remodelação e são moduladas por sinais químicos e físicos que controlam sua ativação, proliferação, migração, diferenciação e sobrevida. 
Quanto à origem as células tronco podem ser classificadas em: embrionárias e adultas.

Nos períodos iniciais após a fecundação ( $4^{\circ}$ ou $5^{\circ}$ dia) o "embrião" (neste momento chamado blastocisto) contém uma camada externa e uma massa celular interna. As células da massa interna vão dar origem ao feto e a parte dos tecidos extrafetais (âmnio e alantóide), ao passo que a camada externa de células (trofoectoderma) vai originar alguns tecidos restritos a placenta. Estas células da massa celular interna podem ser retiradas e cultivadas, dando origem a linhagens de células tronco embrionárias, que têm capacidade de se diferenciarem nos diversos tecidos do adulto. A célula tronco adulta ou somática é um tipo de célula obtida de tecidos após a fase embrionária (feto, recém-nascido, adulto). Até agora, estas células isoladas em humanos são tecido-específicas, ou seja, têm capacidade de diferenciação limitada a um único tipo de tecido ou a alguns poucos tecidos relacionados. Hoje está bem demonstrado que numerosos tecidos humanos (ou talvez todos) têm células tronco, que constituem uma reserva da qual o organismo lança mão para repor células maduras desgastadas ou quando ocorre lesão ou remodelação dos tecidos. Assim são bem conhecidas as células tronco de pele, da mucosa intestinal, do epitélio olfativo, cérebro, fígado, gordura, córnea, retina, polpa dentária, pulmões, músculo esquelético, músculo cardíaco, sangue de placenta e de cordão umbilical, medula óssea e sangue periférico (Zago e Covas, 2006).

Quanto à capacidade de diferenciação, as células tronco podem ser classificadas em: - Totipotentes, quando têm a capacidade de se diferenciarem em todos os tecidos do corpo humano, incluindo anexos embrionários; Pluripotentes, quando são capazes de se diferenciarem em todos os tecidos do corpo humano, exceto placenta e anexos embrionários; Oligopotentes, quando se diferenciam em 
apenas alguns tecidos do corpo humano; e Unipotentes, quando se diferenciam em apenas um único tipo celular (Zago e Covas, 2006).

\subsubsection{Medula óssea e células tronco}

A medula óssea é o sítio doador mais usado clinicamente para a obtenção de células tronco. Ela pode ser caracterizada como um órgão composto por dois sistemas principais que originam linhagens celulares distintas: o sistema hematopoiético propriamente dito e o seu estroma de suporte (Bianco et al., 2001).

Segundo Owen (1985), as evidências de que existe no estroma um sistema de células tronco capaz de originar diversas linhagens e fenótipos celulares fazem da medula óssea o único órgão conhecido onde dois sistemas distintos de células tronco e tecido interligados não só coexistam, mas também cooperem funcionalmente. Assim, foram definidos dois grupos de células tronco na medula óssea: células tronco hematopoiéticas, que dão origem as células sanguíneas e às do sistema imune, e as células tronco do estroma (mesenquimais), que podem formar osso, cartilagem, gordura e tecido muscular.

As células tronco mesenquimais foram originalmente identificadas a partir de células mononucleares da medula óssea de camundongos por Alexander Friedenstein et al. em 1966, que as denominaram células formadoras de colônias fibroblásticas (CFU-F = colony forming units - fibroblastic). Neste estudo observouse que transplantes heterotópicos de medula óssea eram capazes de formar osso novo a partir de células proliferativas que persistiam mesmo após a morte das células hematopoiéticas. 
Em 1968, Friedenstein et al. na tentativa de conhecer as células que levaram a formação de osso novo, desenvolveram uma cultura de células mesenquimais do estroma da medula óssea e posteriormente transplantaram estas células para a cápsula renal e para o tecido subcutâneo de animas de experimentação. Tanto na cápsula renal quanto no subcutâneo houve a formação de um tecido osteogênico constituído por tecido cartilaginoso e ósseo.

As células tronco mesenquimais (CTM) constituem uma pequena população celular da medula óssea, correspondendo a cerca de $0,001 \%$ a $0,01 \%$ de todas as células nucleadas medulares (Pittenger et al., 1999). Entretanto, podem ser isoladas e expandidas com alta frequência e induzidas a se diferenciarem em múltiplas linhagens em condições de cultura definidas.

As CTM são facilmente isoladas de aspirados da medula óssea obtidos da crista ilíaca superior, da tíbia, do fêmur e da coluna vertebral lombar e torácica de humanos e de grandes mamíferos. (Murphy et al., 2003). A diferenciação osteogênica das CTM requer a presença de indutores que incluem betaglicerol fosfato, ácido ascórbico, dexametasona e soro fetal bovino. Na presença destas substâncias as células mesenquimais adquirem a morfologia de osteoblastos e passam a expressar fosfatase alcalina e a depositar matriz extracelular rica em cálcio (Zago e Covas, 2006).

\subsubsection{Células tronco e a reparação óssea.}

No restabelecimento da função de qualquer tecido lesado, é necessária a proliferação celular e a produção de nova matriz, a fim de promover a união dos segmentos teciduais sadios. As células que participam do processo reparador 
costumam estar totalmente diferenciadas e presentes no local, porém, com relação à cicatrização óssea, muitas vezes o restabelecimento da arquitetura de grades defeitos ultrapassa a capacidade funcional dos osteoblastos existentes no sítio a ser reparado. Portanto, como os osteoblastos participam em uma extensão limitada, a presença de células tronco osteoprogenitoras provedoras de novos osteoblastos é determinante para o sucesso do processo cicatricial ósseo. A falência na mobilização, proliferação e diferenciação destas células levam a um atraso ou até mesmo a não formação de um novo tecido ósseo (Yoo e Johnstone, 1998).

Segundo Muschler e Midura (2002), o objetivo do transplante de células tronco mesenquimais é compensar a deficiência no número e/ou atividade das células reparadoras no local interessado, que pode ocorrer por traumatismos prévios, infecção, irradiação ou deficiência vascular. Este procedimento pode melhorar o desempenho dos enxertos osteocondutivos e osteoindutores, mesmo nos locais envolvidos por tecidos sadios. Deste modo, mesmo o processo cicatricial de tecidos normais pode ser prejudicado pela baixa concentração das células tronco mesenquimais (Muschler et al., 2003).

Muitos trabalhos comprovam a importância do fornecimento adicional de células tronco em locais com formação óssea prejudicada, sendo a medula óssea o sítio mais comumente usado na obtenção destas células.

Burwell (1961) foi o primeiro a notar que o uso das células da medula óssea autógena promovia bom resultado na integração de enxertos ósseos não autógenos. Desde então, muitos estudos vêm sendo realizados a fim de melhorar a osteogênese em aloenxertos ou xenoenxertos ósseos (Wientroub et al., 1989).

Salama e Wiessman (1978) descreveram uma série clínica, onde pacientes submetidos à ressecção de tumores ósseos benignos, à correção de perdas ósseas 
pós-traumatismos, a artrodeses e a correção de pseudoartroses foram tratados com a utilização de osso bovino liofilizado associado à medula óssea autógena. Os resultados mostraram que dos 31 pacientes operados, houve sucesso em todos. Os autores concluem que o xenoenxerto por eles utilizado, embora sem células viáveis, serviu apenas como molde (scaffold) para as células vivas presentes na medula óssea.

No ano de 1991, Grundel et al. associaram o aspirado de medula óssea com fosfato de cálcio bifásico cerâmico. A análise feita pelos autores mostrou a união completa de falhas ósseas na ulna de cães após a administração local dessa associação.

Krzymansky et al. (1997) analisaram os efeitos da aplicação de células de aspecto fibroblastóide derivadas da medula óssea e de medula óssea fresca na reparação de defeitos ósseos em ângulo mandibular de coelhos. As células da medula óssea foram cultivadas em laboratório previamente à cirurgia, e juntamente com a medula óssea autóloga fresca foram comparadas ao osso autógeno e ao osso alógeno, por meio de análise histológica e radiográfica. Os autores observaram que os melhores resultados foram obtidos na associação das células da medula óssea expandidas in vitro associadas à medula óssea fresca, e no uso da medula óssea fresca isoladamente. Quando as células expandidas in vitro foram utilizadas isoladamente, a reparação óssea foi ligeiramente menor que a do osso autógeno, mas superior ao osso alógeno. Concluem a partir do exposto que a medula óssea é uma boa fonte de células osteogênicas tanto para o transplante imediato quanto para a expansão in vitro e subseqüente uso.

Em 2003, De Kok et al. comparam o uso de células tronco mesenquimais autógenas e alógenas na formação óssea alveolar em cães. Matrizes de 
hidroxiapatita/fosfato-tricálcio foram utilizadas como carreador das células tronco mesenquimais autógenas e alógenas expandidas em laboratório, para a implantação em um defeito ósseo. Os resultados histométricos mostraram quantidades equivalentes de osso neoformado no interior dos poros tanto das matrizes que continha as células tronco mesenquimais autógenas quanto nas alógenas, em compensação nas matrizes sem a presença das células a neoformação óssea foi menos extensa. Quanto à resposta imunológica, não houve histologicamente, atividade tanto para as células autólogas quanto para as alógenas, e a análise dos níveis de anticorpos circulantes não mostrou resposta imune sistêmica ao hospedeiro em nenhum dos dois tipos celulares. Os autores concluem que as células tronco mesenquimais autólogas e alógenas possuem a capacidade de regeneração óssea em defeitos craniofaciais.

A reconstrução de defeitos na região maxilofacial através do uso de osso alógeno de crista ilíaca associado a osteoblastos derivados da medula óssea foi estudada por Li e Li em 2005. Defeitos no ângulo mandibular foram reconstruídos com o osso alógeno somente e associado aos osteoblastos. As observações radiográficas e histológicas revelaram que o uso das células promoveu a neoformação óssea na margem do defeito e atividade osteogênica no centro, o que não foi observado no outro grupo. Segundo os autores, este tipo de enxerto promoveu a formação óssea pelas propriedades osteogênicas, osteoindutoras e osteocondutivas.

Marei et al. (2005) estudaram os efeitos da células tronco mesenquimais na preservação e regeneração do osso alveolar após extração dentária em coelhos. As células tronco mesenquimais foram expandidas em laboratório e pré-cultivadas em um molde de ácido polilático/poliglicólico (PLGA) para a implantação no defeito ósseo. Os 
animais foram divididos em: sem tratamento, implantação apenas do PLGA e PLGA associado às células tronco. As análises histológica e radiográfica mostraram após 4 semanas manutenção das paredes ósseas alveolares e maior densidade de tecido ósseo no grupo PLGA/células tronco. Os autores concluem que esta associação se mostra promissora na cirurgia dento-alveolar, ainda que estudos longitudinais levando em consideração as diversas variáveis clínicas devam ser realizados.

O uso da engenharia tecidual óssea utilizando células tronco mesenquimais (MSC), cola de fibrina e plasma rico em plaquetas (PRP) na regeneração óssea ao redor de implantes dentários foi avaliada em cães por lto et al. (2006). Após a instalação dos implantes na mandíbula dos cães, os defeitos ósseos periimplantares foram tratados: apenas com fibrina ( I ), MSC e fibrina ( II ); MSC, fibrina e PRP ( III ) e sem tratamento (IV). A análise histológica e histomorfométrica após 8 semanas mostraram uma maior superfície de contato implante/osso da ordem de $53 \%$ no grupo III quando comparado aos grupos IV (29\%), I (25\%) e II (42\%). Assim, neste estudo conclui-se que o uso da associação destes materiais pode ser uma alternativa previsível na regeneração óssea simultânea à colocação de implantes.

Jafarian et al. (2008) avaliaram a capacidade de regeneração óssea comparando dois tipos de carreadores para células tronco mesenquimais em defeitos na mandíbula de cães. Os carreadores analisados foram a hidroxiapatita/fosfato-tricálcio $\beta$ (HA/TCP) e o Bio-Oss esponjoso, que é um osso mineral bovino. Os materiais foram implantados no músculo masseter e em defeitos no ângulo mandibular de cães, associados ou não às células tronco mesenquimais osteoprogenitoras obtidas da medula óssea dos animais. A análise histomorfométrica mostrou maior quantidade de tecido ósseo neoformado nos grupos que receberam as células osteoprogenitoras, pois os grupos com $\underline{\mathrm{HA} / \mathrm{TCP}+}$ 
células e $\underline{\mathrm{HA} / \mathrm{TCP}}$ obtiveram taxas de $65,78 \%$ e $44,9 \%$ respectivamente, e nos grupos Bio-Oss + células e Bio-Oss os valores foram de $50,31 \%$ e $36,84 \%$. Portanto os substitutos ósseos sintéticos bifásicos associados às células tronco mesenquimais podem oferecer melhores condições de regeneração óssea que os tradicionais substitutos ósseos.

Neste mesmo ano, trabalhando também com a associação de hidroxiapatita/fosfato tricálcio- $\beta(\mathrm{HA} / \beta-\mathrm{TCP})+$ células tronco mesenquimais diferenciadas em osteoblastos e expandidas em laboratório (MSC), Shayesteh et al. (2008) puderam concluir que esta combinação é uma alternativa viável para o procedimento de enxertia visando o aumento do assoalho do seio maxilar previamente a instalação de implantes.

Em 2009, Wang et al. analisaram os efeitos da engenharia tecidual óssea utilizando o fosfato tricálcio $\beta$ ( $\beta$-TCP) combinados a osteoblastos autólogos para a reconstrução de defeitos alveolares verticais em cães. Os animais foram divididos em 3 grupos de acordo com o material em questão, que foi o osso autógeno, $\beta$-TCP isolado e $\beta$-TCP + osteoblastos autólogos. Os resultados demonstraram que a engenharia tecidual óssea aumentou substancialmente a nova formação óssea e a mineralização. Assim este estudo revelou a grande potencialidade das biocerâmicas porosas como substrato para osteoblastos em engenharia tecidual óssea.

Pelegrine et al. (2010) avaliaram em humanos, a capacidade de manutenção do rebordo alveolar utilizando o enxerto de medula óssea autóloga fresca em alvéolos dentais pós-extração. No grupo de pacientes que receberam a medula óssea foram obtidos os melhores resultados quanto à manutenção das dimensões ósseas em comparação com os controles. Os autores concluíram que a medula 
óssea autóloga fresca pode contribuir com o processo de reparo alveolar pós exodontia.

A capacidade de formação de novo osso em sítio ectópico foi avaliado por Zhang et al. (2010) com a utilização de fosfato tricálcio beta ( $\beta$-TCP) e osteoblastos diferenciados em laboratório (OST). A associação $\beta$-TCP + OST foram implantados no músculo do dorso de ratos. A análise histométrica revelou uma maior porcentagem de tecido ósseo neoformado no grupo $\beta$-TCP + OST da ordem de $21,58 \%$ em comparação a $4,78 \%$ do grupo $\beta$-TCP isoladamente. Conclui-se que a associação $\beta$-TCP com osteoblastos diferenciados de células tronco mesenquimais possuem boa capacidade osteogênica para a neoformação óssea ectópica.

Rickert et al. (2011) utilizaram o osso mineral bovino (BioOss) como carreador de células tronco mesenquimais (CTM) para a elevação do assoalho de seios maxilares em humanos. A associação BioOss + CTM (grupo teste) foi comparada ao BioOss + osso autógeno (controle) da crista ilíaca após um período de 15 semanas, quando se deu a análise histomorfométricas das peças obtidas. Maiores quantidades de osso neoformado foram encontradas no grupo teste $(17,7 \%)$ quando comparado ao controle $(12,0 \%)$. Os autores concluem que as células tronco mesenquimais semeadas nas partículas de BioOss podem ser uma alternativa ao osso autógeno na reconstrução óssea em seios maxilares.

Zhang et al. (2012) utilizando células tronco mesenquimais (BMSCs) e cola de fibrina (FG) em defeito ósseo alveolar na maxila de animais. Após 6 semanas os resultados histológicos demonstraram que a neoformação óssea no grupo BMSCs foi significativamente maior quando comparado aos grupos FG e controle. A microtomografia computadorizada evidenciou maiores áreas de calcificação e o defeito ósseo alveolar totalmente preenchido por osso reparacional. Assim, os 
autores sugerem que esta estratégia de combinar as células tronco mesenquimais em um carreador de cola de fibrina pode ser efetivo no reparo dos defeitos ósseos do rebordo alveolar.

Utilizando outro carreador para as células tronco, Xia et al. (2012) avaliaram a capacidade das mesmas em um gel de alginato de sódio na formação óssea ortotópica e ectópica em coelhos. Verificaram que esta associação foi biocompatível, e que o gel de alginato de sódio tem uma boa capacidade em carrear as células tronco, pois adequada neoformação óssea tanto ectópica quanto ortotópica (defeitos críticos na calvária) nos animais foi constatada.

Xu et al. (2012) analisaram a capacidade de reparação óssea em defeitos críticos na calvária de ratos utilizando células tronco mesenquimais (BMSCs), fator de crescimento derivado das plaquetas recombinante humano (rhPDGF-BB) em um carreador de fosfato tricálcio- $\beta$ ( $\beta$-TCP). Após 8 semanas os resultados histológicos e de microtomografia demonstraram no grupo rhPDGF-BB + BMSCs $+\beta-T C P$ uma formação óssea e mineralização significativamente maior que os demais grupos, bem como uma maior densidade de tecido preenchendo os espaços do biomaterial carreador. 


\subsection{BIOMATERIAIS}

\subsubsection{Conceitos, Classificações, Definições e Propriedades}

A busca por materiais que substituissem partes perdidas do organismo humano vem de muitos anos atrás, tal processo remonta a pré-história, como demonstrado pelos achados arqueológicos de crânios com perfurações em que a tentativa de recompor a área afetada era feita com placas de ouro e prata (Laurencin, 2004).

Com o intuito de eliminar os problemas relativos à morbidade resultante da remoção do osso autógeno, a possível rejeição imunológica e transmissão de doenças pelos ossos homógenos, bem como a discutível ação de príons causadores da Encefalopatia Espongiforme contidos nos enxertos ósseos heterógenos é que substitutos ósseos sintéticos têm sido desenvolvidos e são hoje usados em grande parte das cirurgias reconstrutivas (De Long et al., 2007).

Há duas questões em jogo quanto ao significado de biomaterial, a primeira diz respeito à direção em que o prefixo "bio" está apontando, ou seja, estamos nos referindo a algum produto derivado de algo que tenha vida ou estamos usando algum produto em benefício da vida. Assim uma biocerâmica seria considerada uma cerâmica derivada de algum organismo vivo ou seria para o uso em um organismo vivo? E em segundo, que se tornou um ponto ainda maior, diz respeito ao conceito do que é um material (Willians, 2009).

Apesar de que várias tentativas, esta questão não foi levada em pauta até a Conferência de Consenso sobre Definições em Ciência de Biomateriais, em 1987, da Sociedade Européia de Biomateriais (Williams, 1987), em que ficou determinado 
que biomaterial seria um material não viável utilizado em dispositivos médicos destinados a interagir com sistemas biológicos. Mas novos debates foram realizados e a questão da viabilidade foi eliminada, a partir do qual um novo conceito foi elaborado em 1999 para biomaterial como sendo "um material destinado a entrar em contato com sistemas biológicos para avaliar, tratar, aumentar ou substituir qualquer tecido, orgão ou função do organismo" (Williams, 1999).

Com a grande evolução e aumento das pesquisas biomédicas relacionadas à nanotecnologia, engenharia tecidual e genética, novamente percebeu-se a necessidade de se reformular o conceito de biomaterial. Assim em 2009, Williams o definiu como: "Substância feita pela engenharia para dar forma e na qual, sozinha ou como parte de um sistema complexo, é usada para direcionar o curso de algum procedimento trapêutico ou diagnóstico, pelo controle das interações com componentes dos sistemas vivos em medicina humana ou veterinária”.

Diferentes tipos de biomateriais podem ser usados dependendo da função ou tecido a ser substituído. Quanto ao tecido ósseo, são também denominados substitutos ósseos e têm como principal função a reconstituição ou reforço deste tecido seja ele perdido traumaticamente ou por atrofia (Khoury, 2011).

Os biomateriais para substituição e/ou reconstrução óssea podem ser classificados quanto à sua composição química em: materiais metálicos e ligas $\underline{\text { metálicas, }}$ quando da presença de ligações metálicas; materiais cerâmicos, com ligações iônicas presentes; materiais poliméricos, com ligações covalentes, e compósitos quando há uma combinação de materiais (Soares e Granjeiro, 2011). Quanto ao comportamento biológico são divididos em: bioinertes, quando não produzem resposta biológica adversa; bioativos, quando favorecem a ligação química entre o material implantado e o tecido hospedeiro; biorreativos, quando 
ficam no limite entre os bioinertes e os bioativos; biorreabsorvíveis, quando são degradados após certo período de tempo; biotolerantes, quando são parcialmente aceitos pelo organismo e levam a formação de uma cápsula fibrosa ao seu redor; biofuncionais, quando atendem aos requisitos de funcionalidade dada as suas propriedades mecânicas, químicas, ópticas e elétricas; e bioartificiais quando há uma combinação de materiais sintéticos e células vivas visando à reconstituição tecidual (Williams, 2009; Takyia et al., 2011).

Os biomateriais para reconstrução óssea, quando possível, devem ser inertes, a fim de não causarem reação de corpo estranho com o tecido local, bioativos para promover uma adequada ligação com os minerais da matriz óssea, reabsorvíveis ao longo do tempo com o intuito de serem substituídos por osso nativo, biofuncionais a fim de resistirem aos esforços mecânicos e bioartificiais para serem capazes de favorecer a proliferação e desenvolvimento de células na sua superfície. Assim, bom desempenho osteocondutor e osteoindutor são os pontos chave da pesquisa dos biomateriais para substituição óssea (Janicki e Schmidmaier, 2011; Vallet-Regi e Ruiz-Hernandez, 2012).

\subsubsection{Biocerâmicas}

Diferentemente de outros compostos como metais e polímeros, as cerâmicas podem ser encontradas em diversos organismos vivos desempenhando papéis importantes no seu desenvolvimento. O processo de mineralização de estruturas biológicas é que determina a formação dos esqueletos de várias espécies vivas, e tal atividade só foi possível de se iniciar quando o primeiro organismo vivo foi capaz de controlar a formação de um cristal cerâmico. Os silicatos, os fosfatos e os carbonatos são os três principais grupos de íons com capacidade de formação de 
compostos cerâmicos em que a gênese e o desenvolvimento podem ser controlados por organismos vivos (Santos e Barreira-Pinto, 2011).

Dentre todos os organismos vivos, a constituição mineral média é da ordem de $50 \%$ para os sais de cálcio e $25 \%$ para os de fosfato, da mesma forma no organismo humano, os tecidos calcificados que formam osso e dentes são constituídos principalmente de minerais a base de fosfato de cálcio. No tecido ósseo essa combinação de íons forma a hidroxiapatita, um composto essencial no processo de mineralização das fibras colágenas presentes no tecido osteóide sintetizado pelos osteoblastos (Santos e Barreira-Pinto, 2011).

Durante o desenvolvimento e pesquisa em relação às biocerâmicas, as de primeira geração eram fabricadas com o objetivo maior de substituir o tecido danificado, levando em conta apenas suas semelhanças físico-mecânicas com o tecido original, principalmente a resistência mecânica. Na segunda geração destes materiais, o objetivo era fundamentado no reparo do tecido lesado por uma nova cerâmica que imitasse não somente as propriedades físico-mecânicas, mas também as propriedades químicas do tecido original. $\mathrm{Na}$ terceira geração, agora a preocupação se dá em relação ao processo regenerativo do tecido ósseo. Nesse momento, nasce a maior parte das cerâmicas com propriedades bioativas, com porosidades controladas que facilitam o desenvolvimento celular, e com graus de reabsorção/degradação compatíveis com o processo de reconstituição óssea (Santos e Barreira-Pinto, 2011; Vallet-Regí e Ruiz-Hernández, 2012).

O primeiro uso de uma cerâmica para preenchimento de defeito ósseo foi realizado em 1894 por Dressman, o gesso $\left(\mathrm{Ca}_{2} \mathrm{So}_{4} \cdot{ }_{1 / 2} \mathrm{H}_{2} \mathrm{O}\right)$ empregado clinicamente não teve grandes atrativos, pois possuía baixa resistência mecânica e era 
completamente reabsorvido pelo organismo o que levava a fragmentação e degradação na área implantada (Krieger, 2003).

Foi apenas em 1967 que um engenheiro especializado em cerâmica, Larry L. Hench, conheceu um coronel do exército americano que havia voltado do Vietnã e o mesmo reclamava que milhares de soldados estavam tendo braços e pernas amputados devido a implantes defeituosos, metais e plásticos que eram rejeitados pelo corpo. O cientista da Universidade da Flórida deu inicio então as pesquisas relacionadas aos biomateriais para substituição óssea, onde conseguiu um vidro que se unia tão bem aos ossos e tecidos dos ratos, que era quase impossível separá-los, levando a acreditar que o material desenvolvido atraía as células ósseas. Depois de vários testes e aperfeiçoamento do material, a Food and Drug Administration aprovou em 1985 a petição da U.S. Biomaterials Corp. , de Baltimore, a utilizar o BioGlass, como agora é conhecido, nas reconstruções ósseas (Krieger, 2003).

A partir de então, as biocerâmicas passaram a ser amplamente pesquisadas e utilizadas clinicamente em reconstruções ósseas nas áreas de cirurgia oral e maxilofacial, implantodontia, periodontia e ortopedia, pois apresentam excelente biocompatibilidade, aliadas a boa resistência e propriedades bioativas. (Dorozhkim, 2010; Li e Kawashita, 2011; Schimitt et al., 2012).

As biocerâmicas por sua vez podem ser divididas quanto a sua composição química em: cerâmicas a base de fosfato de cálcio, biovidros, cimentos ósseos a base de sais de cálcio (fosfato de cálcio, carbonato de cálcio e sulfato de cálcio), cerâmicas a base alumina, a base de zircônia e a base de sílica (Santos e BarreiraPinto, 2011; Vallet-Regí e Ruiz-Hernández, 2012). 


\subsubsection{Biocerâmicas a base de Fosfato de Cálcio}

A aplicação de materiais a base de cerâmicas de fosfato de cálcio como enxertos ósseos, tem recebido recentemente considerável atenção, porque estes materiais são notavelmente biocompatíveis (Chappard et al., 2010), possuem propriedades bioativas (Aoki, 1991; Xingdong et al., 1991) e assemelham-se bastante a constituição do tecido ósseo (LeGeros, 2002).

Os fosfatos de cálcio são sais produzidos, em geral, a partir do ácido ortofosfórico $\left(\mathrm{H}_{3} \mathrm{PO}_{4}\right)$ e apresentam, portanto, composições fundamentadas em seus produtos característicos de dissociação: $\mathrm{H}_{2} \mathrm{PO}_{4}^{-}, \mathrm{HPO}_{4}^{-2}$ e $\mathrm{PO}_{4}^{-3}$. Isso significa que as cerâmicas constituídas de $\mathrm{H}_{2} \mathrm{PO}_{4}{ }^{-}$são formadas em ambientes ácidos, enquanto que aquelas constituídas de $\mathrm{PO}_{4}^{-3}$ são formadas em ambientes mais básicos (Santos e Barreira-Pinto, 2011).

Dentre estas biocerâmicas, os dois fosfatos de cálcio mais utilizados para fins biomédicos são, a hidroxiapatita (HA) e fosfato tricálcio (TCP) sob as formas alotrópicas $\alpha$ e $\beta$, pois têm como características serem atóxicos, reabsorvíveis e não inflamatórios, não causarem resposta imunológica, irritação ou reação de corpo estranho (Chappard et al., 2010; Santos e Barreira-Pinto, 2011). Além destas, a capacidade osteocondutora promovida pela microarquitetura porosa de sua matriz (Frenken et al., 2010; ), bem como seu poder osteoindutor (Li e Kawashita, 2011; Yuan et al., 2010), aliado ao bom desempenho na capacidade de carrear células osteogênicas (Shayesteh et al., 2008; Peng et al., 2011; Reddy et al., 2013) levam ao seu grande uso no campo das reconstruções ósseas (Wakimoto et al., 2011; Schmitt et al., 2012; Lindgren et al., 2012). 
A associação de HA e $\beta$-TCP é também conhecida como cerâmica de fosfato de cálcio bifásica, e tem mostrado melhor desempenho em tecidos vivos quando associadas do que quando utilizadas isoladamente (Matsushima et al., 2009; Frenken et al., 2010; Mardas et al., 2011; Schmitt et al., 2012).

De acordo com a literatura, a primeira tentativa de uso da biocerâmicas de ortofosfato de cálcio como um material de preenchimento de defeitos ósseos foi realizado por Albee em 1920, onde o autor utilizou o fosfato tricálcio como auxiliar na reparação óssea em coelhos.

Mais de 50 anos depois, o primeiro relato do uso das biocerâmicas de fosfato de cálcio na odontologia foi feito por Nery et al. em 1975. Neste estudo o autor utilizou a hidroxiapatita e o fosfato tricálcio com $50 \%$ de porosidade e diâmetro médio de cada poro variando de 800 a 1000 um, que foram implantados em defeitos periodontais infraósseos. Os resultados mostraram que esta biocerâmica é bem tolerada pelos tecidos, não provoca reações tóxicas e induz crescimento de novo tecido osteóide para dentro dos poros do material, bem como a reparação do defeito periodontal.

Em 1978, o fosfato tricálcio isoladamente foi utilizado também por Nery et al. para a reconstrução do rebordo alveolar de cães. Os resultados demonstraram que, o material não apresentou toxicidade e foi bem tolerado pelos tecidos, o que permitiu crescimento de osso e tecido mole para dentro dos poros do material, criando uma adequada ligação biomecânica entre a biocerâmica e as estruturas adjacentes.

Nade et al. em 1983 estudaram a capacidade das biocerâmicas em servir como um carreador para as células contidas na medula óssea. Para isso foram utilizadas quatro biocerâmicas: a alumina, o aluminato de cálcio, a hidroxiapatita e o fosfato tricálcio, que foram impregnadas com a medula óssea autóloga previamente à 
implantação no músculo de coelhos. As análises histológicas do $14^{\circ}$ até o $182^{\circ}$ dia mostraram a presença de tecido ósseo neoformado no interior dos poros das cerâmicas e aderido as mesmas, demonstrando assim a capacidade de formação ectópica de osso com esta associação.

A capacidade da hidroxiapatita em auxiliar no processo de reparo e reconstrução óssea de fissuras palatinas em cães foi estudada por Cullum et al. (1988). Fissuras palatinas bilaterais foram criadas cirurgicamente, e a reconstrução deste defeito ósseo se deu com o enxerto de hidroxiapatita ou osso autógeno particulado. Os resultados mostraram que a hidroxiapatita não promoveu reações adversas locais e sistêmicas, obteve grande sucesso em fechar as fistulas buco nasais e restabelecer a condição anatômica da maxila assim como o osso autógeno.

O uso das cerâmicas de fosfato de cálcio em alvéolos dentários de ratos foram testados por Rosa et al. (1995). Os implantes de hidroxiapatita, e de fosfato de tricálcio foram inseridos no defeito ósseo causado pela extração dentária, onde análises histométricas foram realizadas. Os resultados mostraram que houve formação de uma menor quantidade de osso durante todos os períodos de estudo, e que apesar de biocompatíveis, de alguma forma retardaram o processo de reparação alveolar quando comparados aos controles.

Em 1995, Fujikawa et al. em um estudo sobre a reação histopatológica das cerâmicas de fosfato de cálcio na reparação de defeitos ósseos periodontais de cães, também demonstrou adequada biocompatibilidade e poder osteocondutivos destes materiais.

Daculsi et al. (1999) analisaram in vivo a biocompatibilidade e a biofuncionalidade das biocerâmicas de fosfato de cálcio bifásicas na substituição do tecido ósseo. Os autores puderam concluir que a hidroxiapatita e o fosfato tricálcio 
são progressivamente reabsorvidos e substituídos por osso novo, e também são capazes de atuar como um favorável meio para a colonização de células osteogênicas.

Em 2001, Alam et al. avaliaram a influência de diferentes proporções de hidroxiapatita (HA) e fosfato tricálcio $\beta(\beta-T C P)$ na capacidade de carrear a proteína óssea morfogenética 2 recombinante humana (rhBMP-2). Os resultados demonstraram que todos os espécimes contendo a rhBMP-2 exibiram neoformação óssea, enquanto os controles mostraram a presença apenas de tecido conjuntivo. Os espécimes contendo maior porcentagem de HA em relação ao TCP revelaram as maiores porcentagens de osso neoformado ao final de 4 semanas. Os autores concluíram que a formação de novo osso depende do conteúdo da biocerâmica bifásica, e que quanto maior a relação HA/TCP e a concentração da rhBMP-2 mais elevados são os valores histométricos encontrados para o tecido ósseo.

Sabendo que a hidroxiapatita e o fosfato tricálcio possuem graus diferentes de degradação quando em contato com sistemas biológicos, Fujita et al. (2003a) investigaram as diferenças na osteogênese e reabsorção destas duas biocerâmicas na forma de blocos utilizadas para a reconstrução óssea do tipo onlay. Os blocos contendo macro e microporos foram implantados entre o osso parietal e o periósteo de recobrimento cranial de ratos, seguido pelas análises histomorfométricas. Os resultados demonstraram que em duas semanas novo osso nas porosidades e aderido aos implantes pode ser constatado, e quando analisado em 24 semanas, os blocos de HA permaneceram estáveis, mas os de $\beta$-TCP continham fraturas e certo grau de reabsorção. Histomorfometricamente o volume de osso era maior nos arredores da HA do que do $\beta$-TCP. Concluíram assim que os blocos de HA podem ser uma alternativa viável ao osso autógeno nos enxerto onlay, pois apresentam boa 
osteogênese e estabilidade, mas quando do uso do $\beta$-TCP cuidados devem ser tomados quanto aos esforços mecânicos presentes na área a ser reconstruída.

Bombonato-Prado et al. em 2004 avaliou qualitativa e quantitativamente através de microscopia de luz e eletrônica de varredura, os efeitos de uma bebida alcoólica na reparação alveolar, comparando, nesta situação, a ação de uma biocerâmica de fosfato de cálcio bifásica (Osteosynt) na neoformação óssea. Teve como conclusão que, a utilização da biocerâmica composta de hidroxiapatita e fosfato tricálcio enxertada no interior do alvéolo dentário dos animais minimizou os efeitos deletérios do alcoolismo crônico sobre a reparação alveolar.

Arinzeh et al. (2005) realizaram um estudo comparativo sobre a capacidade das células tronco mesenquimais (CTM) associadas a cerâmica de fosfato de cálcio bifásica na indução da formação óssea. Várias proporções de hidroxiapatita (HA) e fosfato tricálcio $\beta$ ( $\beta$-TCP) foram associadas às CTMs e inseridas ectopicamente em ratos. A análise dos espécimes revelou que as CTMs podem ser consideradas uma fonte abundante e viável de células para a engenharia tecidual óssea, e que a melhor proporção HA/ß-TCP para associação com as mesmas é de 20/80.

Também em 2005, Shiratori et al. comprovaram imunohistoquimicamente que o $\beta$-TCP utilizado no preenchimento de defeitos ósseos femorais é capaz de expressar osteocalcina, osteopontina e RNAm nas células reparativas presentes na área.

Trojani et al. (2006) avaliaram in vivo a biocompatibilidade e a efetividade na formação óssea ectópica da associação HA/ $\beta$-TCP com células da medula óssea indiferenciadas em ratos. A material juntamente com o pool de células foi injetado no subcutâneo e em sítios intramusculares, que após um período de 4 e 8 semanas foram analisados histologicamente. Os resultados mostraram a presença de um 
osso novo contendo grande quantidade de osteoblastos e osteoclastos nos espaços entre os grânulos do material no grupo onde as células foram utilizadas, aspecto este não encontrado nos grupos controle contendo apenas o material. Concluíram que esta biocerâmica bifásica associada às células da medula óssea serviu como arcabouço para a deposição óssea e pode ser considerado um novo substituto ósseo com promissoras características osteoindutoras.

Bodde et al. (2007) comparou o $\beta$-TCP à cerâmica de fosfato de cálcio bifásica contendo HA/ $\beta$-TCP na proporção de $75 / 25$ no processo de reparo do osso trabecular de ovelhas. As análises histomorfométricas demonstraram que $36 \%$ do $\beta$ TCP utilizado isoladamente foi reabsorvido em 26 semanas, enquanto a HA/ $\beta$-TCP se manteve intacta. A neoformação para ambos os materiais ocorreu, mas quantidades maiores de volume ósseo periférico foram observadas na cerâmica bifásica. Assim, concluíram que os dois substitutos ósseos utilizados são biocompatíveis e têm boa capacidade osteocondutora, mas a degradação do $\beta$-TCP é mais rápida à custa da dissolução e alguma atividade reabsortiva celular.

A capacidade das cerâmicas de fosfato de cálcio bifásica em regenerar deiscências ósseas periodontais foi estudada por Shi et al. em 2008. Cães da raça beagle foram utilizados para a criação cirúrgica de deiscências ósseas alveolares, onde de um lado foi preenchido com a biocerâmica composta por HA/ $\beta$-TCP e do outro (controle) apenas a raspagem da raiz descoberta e fechamento do retalho. Análises por meio de micro tomografia computadorizadas, microscopia de luz e fluorescente foram adotadas na análise em 4, 12 e 24 semanas. A biocerâmica foi biocompatível e a regeneração óssea foi mais efetiva no grupo teste comparado aos controles. Também foi notado que o material impediu a proliferação apical do epitélio juncional, favorecendo a formação de cemento e osso, bem como a proliferação de 
um tecido conjuntivo aderido ao novo cemento constituinte da superfície radicular. Os autores concluíram que a cerâmica bifásica pode ser considerada um material com capacidade de manter o arcabouço para regeneração periodontal efetiva.

Clinicamente, Cordaro et al. (2008) compararam o uso da cerâmica de fosfato de cálcio bifásica (BoneCeramic - Straumann) com o osso bovino inorgânico (BioOss - Geistlich) para o levantamento do assoalho de seios maxilares humanos. Estudos histomorfométricos foram realizados em 47 seios preenchidos com estes biomateriais após um período de 6 meses. Verificou-se íntimo contato do osso neoformado com a superfície de ambos os materiais, e maior reabsorção do osso bovino. Conclui-se que os dois biomateriais, podem ser indicados na terapêutica reconstrutora óssea em seios maxilares.

A engenharia tecidual óssea utilizando as células tronco mesenquimais (CTMs) carreadas por uma cerâmica bifásica composta pela HA/ $\beta$-TCP foi estudada por Shayesteh et al., (2008) também para a elevação de seios maxilares humanos. As CTMs foram cultivadas e expandidas a partir de aspirados de medula óssea autóloga previamente a implantação em conjunto com a biocerâmica nos seios a serem reconstruídos. Os resultados revelaram uma taxa de sucesso dos implantes instalados de 93,0\% em um sítio ósseo reconstruído que, histomorfometricamente continha $41,34 \%$ de osso neoformado sem apresentar reações inflamatórias. Os autores concluem que os achados clínicos e histológicos do levantamento de seio maxilar com HA/ $\beta$-TCP em combinação com as CTMs promovem uma viável alternativa reconstrutora para a reabilitação com implantes, e que a adição das células pode favorecer a neoformação óssea sinusal.

Em 2009 Friedman et al. utilizando um protocolo parecido ao anterior também analisaram o comportamento da HA/ß-TCP na proporção de 60/40 (BoneCeramic - 
Straumann) em seios maxilares humanos e em reconstruções alveolares, mas sem a adição das CTMs. O autor observou após 6 meses um íntimo contato das partículas do material com o osso neoformado da ordem de 55,39 \% e um total de volume osso/material de 58,43\%. Concluíram que esta biocerâmica é um osteocondutor com boa previsibilidade para estas modalidades de reconstruções.

Matsushima et al. (2009) avaliaram a capacidade osteogênica in vitro e a formação óssea in vivo das células tronco mesenquimais (CTMs) carreadas por duas cerâmicas de fosfato de cálcio. As CTMs foram previamente isoladas em laboratório e semeadas na HA e no $\beta$-TCP que serviram como carreador. In vitro foi demonstrada a atividade da fosfatase alcalina, o que confirmou a diferenciação osteogênica das CTMs no interior das duas biocerâmicas. In vivo, as análises histológica e de microtomografia computadorizada após 8 semanas da implantação das células/biocerâmica mostraram formação óssea tanto na HA quanto no $\beta$-TCP, mas tal formação foi mais expressiva no primeiro material do que no segundo. Estes resultados levaram a conclusão de que as CTMs cultivadas nas biocerâmicas estudadas podem reter sua capacidade osteogênica e promover um meio de reconstrução óssea a partir da engenharia tecidual.

Em uma abordagem clínica Mardas et al. (2010), analisaram as alterações das cristas alveolares após extração dentária e enxerto com BoneCeramic (Straumann) e BioOss (Geistlich), e puderam constatar que estes biomateriais são capazes de preservar parcialmente a largura e a altura do rebordo alveolar.

Em se tratando de manutenção das dimensões ósseas alveolares, De Coster et al. (2011) avaliaram a capacidade do enxerto de HA/ $\beta$-TCP (BoneCeramic Straumann) em prevenir a reabsorção óssea pós-extração em humanos. Os achados mostraram que o material foi capaz de preservar as dimensões do alvéolo 
dentário, mas interferiu no processo de reparo alveolar, pois o tecido encontrado apresentava-se com menor quantidade de osso neoformado e com aspecto clínico mole durante a instalação dos implantes. Os autores concluíram que novas pesquisas devam ser realizadas a fim de conhecer os mecanismos biológicos e os resultados em longo prazo.

Novamente Mardas et al. (2011) também seguindo a mesma linha de pesquisa compararam a biocerâmica de fosfato de cálcio bifásica (BoneCeramic Straumann) com o osso bovino inorgânico (BioOss - Geistlich) para a manutenção da estrutura óssea alveolar pós-exodontia em humanos. Tomadas radiográficas padronizadas foram realizadas após a extração dentária, após o preenchimento com o biomaterial, 16 e 32 semanas após a cirurgia, seguido por medidas da posição das cristas ósseas mesiais e distais, e também na região central. Os resultados mostraram que houve um ganho do nível ósseo comparando o alvéolo antes do preenchimento e após 32 semanas para os dois biomateriais, mas o BoneCeramic apresentou valores estatisticamente significantivamente melhores de manutenção das cristas ósseas em relação ao BioOss. Conclui-se que ambos os materiais apresentaram comportamentos radiográficos similares quando utilizados para a manutenção da crista óssea alveolar.

Wakimoto et al. (2011) analisaram em humanos a osteogênese e o processo de reparo de feridas de extração dentária após o enxerto de uma biocerâmica de fosfato de cálcio bifásica contendo HA/ß-TCP na proporção de 15/85 respectivamente. As imagens obtidas na microtomografia mostraram osso neoformado em todos os espécimes, e histologicamente observou-se alta atividade osteogênica com osteoblastos invadindo as porosidades do material. Os autores concluíram que a biocerâmica foi efetiva em reparar o defeito ósseo alveolar, pois 
apresentou boa capacidade osteocondutora, o que facilitou a migração de novos vasos sanguíneos e células osteogênicas.

Em 2012, Schmitt et al. investigaram em humanos o comportamento clínico e histológico de 4 biomateriais utilizados no processo de enxertia em seios maxilares. Uma amostra de 50 pacientes com necessidade de elevação do assoalho sinusal foi incluída neste estudo. Os materiais a serem inseridos no interior do seio maxilar foram a HA/ $\beta$-TCP (BoneCeramic - Straumann), osso bovino inorgânico (BioOss Geistlich), osso alógeno medular mineralizado (Puros - Zimmer) e osso autógeno do ângulo mandibular $(A B)$, que após um período de cicatrização de 5 meses deu início as análises histológicas e de microrradiografias. Os dados obtidos mostraram um volume de osso neoformado de $30,28 \%$ para o BoneCeramic, $24.9 \%$ para o BioOss, $35,41 \%$ para o Puros e de $41,74 \%$ pra o osso autógeno. Em relação à presença do material de enxertia a cerâmica bifásica obteve valores da ordem de $15,8 \%$ e osso bovino inorgânico de $21,36 \%$. Os autores concluíram que o osso autógeno ainda é o padrão ouro nas reconstruções ósseas em seios maxilares, mas que os outros biomateriais estudados mostraram resultados compatíveis e viáveis para esta abordagem terapêutica.

Sabendo-se que diversos destes materiais têm bom comportamento quanto á manutenção do rebordo alveolar pós-extração, Antunes et al. (2013) estudaram o comportamento do tecido ósseo reconstruído para a posterior instalação de implantes osseointegrados. Cães da raça Labrador tiveram seus pré-molares extraídos e após um período de 12 semanas a área foi reaberta e 4 defeitos ósseos foram criados de cada lado da mandíbula. De um lado estes defeitos foram preenchidos com BoneCeramic (Struamann), BioOss (Geistlich), Osso autógeno e coágulo, e do outro nada foi enxertado. Após 8 semanas as áreas foram reabertas, 
do lado direito foram instalados 4 implantes na área previamente regenerada, do lado esquerdo criou-se neste momento 4 defeitos ósseos, seguido pela instalação dos implantes e enxerto do defeito circunferencial com o mesmo protocolo do lado contralateral. Após 2 meses da instalação dos implantes os animais foram sacrificados para análise de estabilidade de ressonância dos implantes e através da histologia. Os resultados mostraram uma maior área óssea (BA) e de interface osso/implante $(\mathrm{BIC})$ para a reconstrução óssea tardia em relação à imediata. $\mathrm{O}$ coágulo sanguíneo foi o que apresentou maiores valores de BA e BIC, os outros biomateriais apresentaram valores similares. A estabilidade dos implantes medida por análise de frequência de ressonância foi maior nos animais com abordagem tardia, e em relação ao biomaterial utilizado o menor valor se deu com o uso do BioOss. Concluíram a partir dos resultados que implantes instalados em sítios já reconstruídos e cicatrizados apresentam melhor estabilidade em consequência de uma maior área óssea e de interface com o implante. 


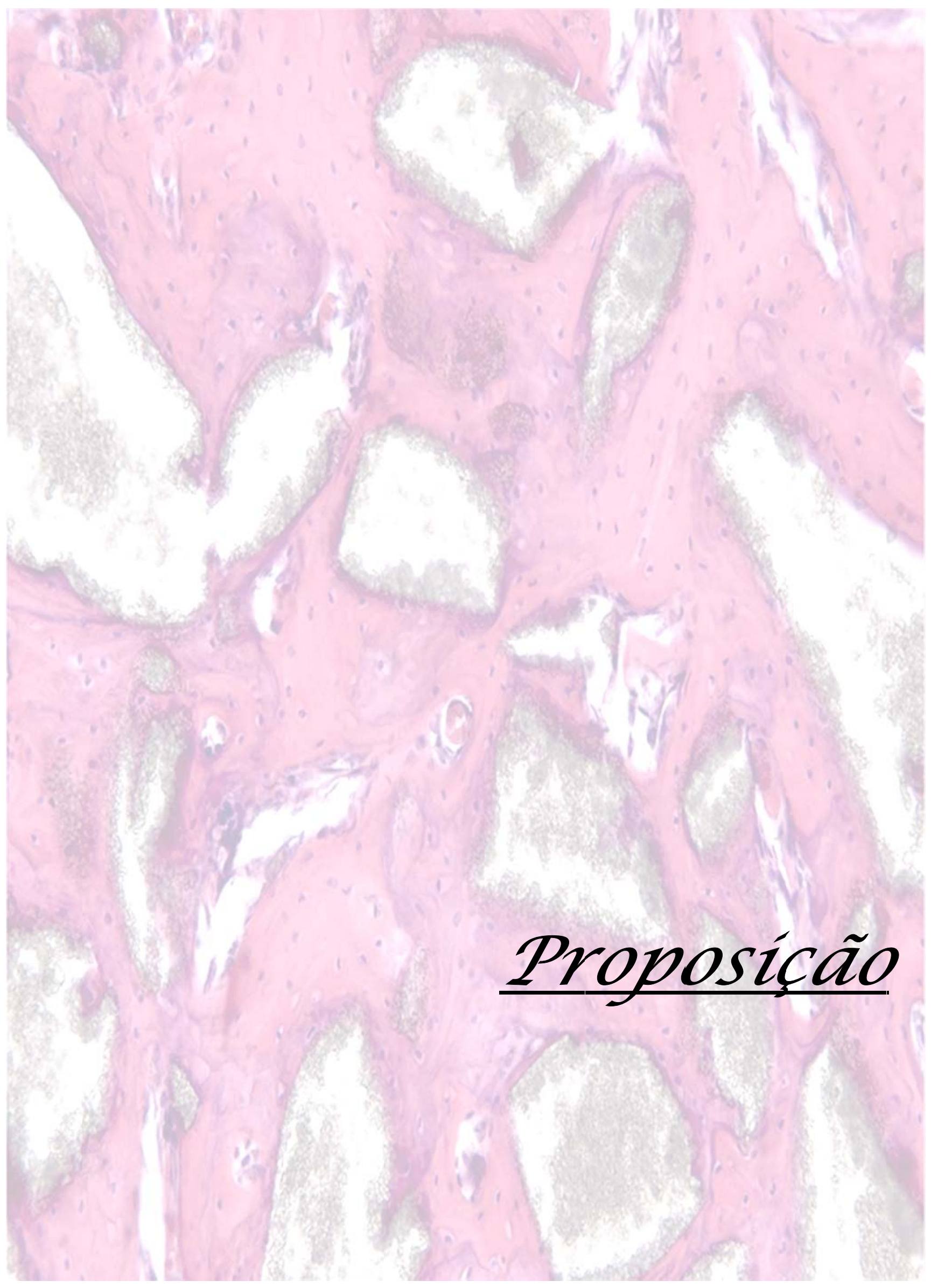




\section{Proposição}

O objetivo do presente trabalho foi:

1. Avaliar qualitativamente e quantitativamente o osso reparacional após a implantação de biomateriais em defeitos ósseos produzidos pela extração dentária.

2. Avaliar histomorfometricamente a biocompatibilidade, a osteointegração e a capacidade osteogênica do implante/enxerto de uma biocerâmica isoladamente ou carreando células osteoblásticas, associadas ou não ao osso autógeno provindo da calota craniana, em defeitos ósseos pósextração dentária, bem como compará-los a dinâmica da reparação óssea alveolar.

Para tanto, foram realizadas as observações histológicas em microscopia de luz e eletrônica de varredura, bem como histométricas dos tecidos reparacionais e dos materiais implantados/enxertados nos períodos de 7, 21 e 42 dias após a extração dentária. 


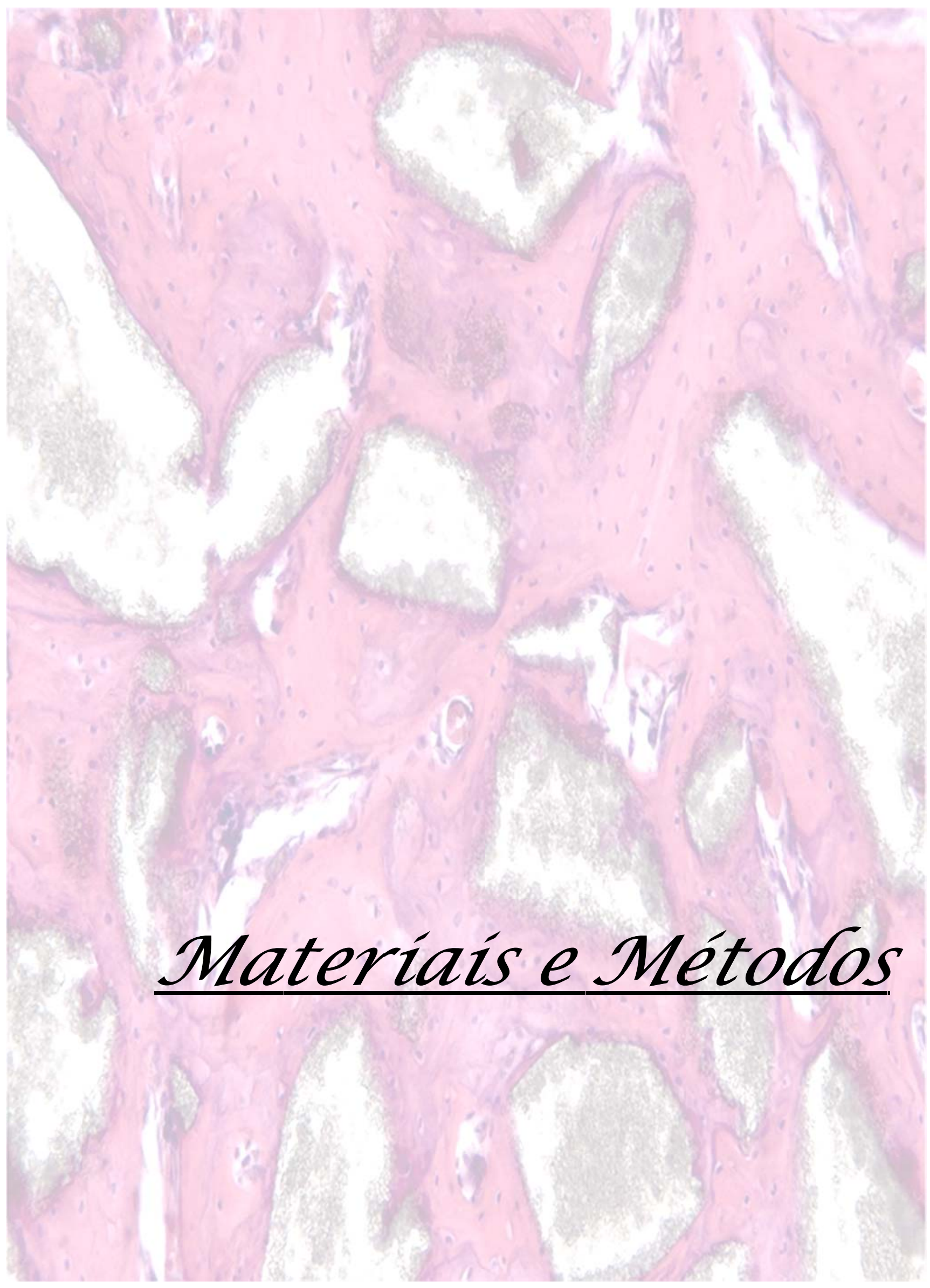




\section{Materiais e Métodos}

\subsection{ANIMAIS UTILIZADOS}

Todos os animais utilizados nesta pesquisa receberam cuidados humanos de acordo com o critério do Conselho Nacional de Pesquisa e o protocolo do estudo foi previamente submetido ao Comitê de Ética para uso de Animais da Faculdade de Medicina de Ribeirão Preto da Universidade de São Paulo - número 10.1.644.53.8 (Anexo).

Foram utilizados 126 ratos machos (Rattus norvegicus, variedade Wistar), pesando entre 200 a 250 gramas alimentados com ração balanceada 6042 Nuvilab CR-1 (Nuvital, Colombo-Paraná, Brasil); composta de farelo de milho, farelo de soja, farelo de trigo, carbonato de cálcio, fosfato bicálcico, cloreto de sódio, premix vitamínico mineral, aminoácidos, aditivo antioxidante; água e mantidos em caixas

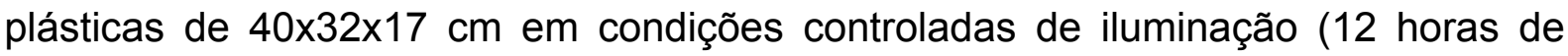
luz/12 horas de escuro) e temperatura $\left(21^{\circ} \mathrm{C}\right.$ a $\left.25^{\circ} \mathrm{C}\right)$.

\subsection{PROTOCOLO EXPERIMENTAL}

Os animais utilizados receberam previamente um vermífugo de uso animal, durante 3 dias, (Systamex - Schering do Brasil, São Paulo, Brasil).

Todos os animais foram submetidos a uma cirurgia para extração do dente incisivo superior direito e divididos em 8 grupos, como segue:, 
1. Grupo controle (C) - O defeito ósseo foi preenchido por coágulo sanguíneo.

2. Grupo osso autógeno (OA) - O defeito ósseo foi preenchido por osso autógeno da calvária particulado.

3. Grupo células osteoblásticas (CO) - O defeito ósseo foi preenchido com células osteoblásticas da medula óssea.

4. Grupo osso autógeno + células osteoblásticas $(O A+C O)$ - $O$ defeito ósseo foi preenchido por osso autógeno da calvária particulado associado às células osteoblásticas da medula óssea.

5. Grupo biocerâmica (BC) - O defeito ósseo foi preenchido pela biocerâmica (Straumann ${ }^{\circledR}$ BoneCeramic) (Figura 1).

6. Grupo biocerâmica + osso autógeno $(B C+O A)-O$ defeito ósseo foi preenchido por osso autógeno da calvária particulado associado à biocerâmica.

7. Grupo biocerâmica + células osteoblásticas $(B C+C O)-O$ defeito ósseo foi preenchido por células osteoblásticas da medula óssea carreadas pela biocerâmica.

8. Grupo biocerâmica + células osteoblásticas + osso autógeno $(B C+C O+O A)$ O defeito ósseo foi preenchido por osso autógeno da calvária particulado associado às células osteoblásticas da medula óssea carreadas pela biocerâmica. 


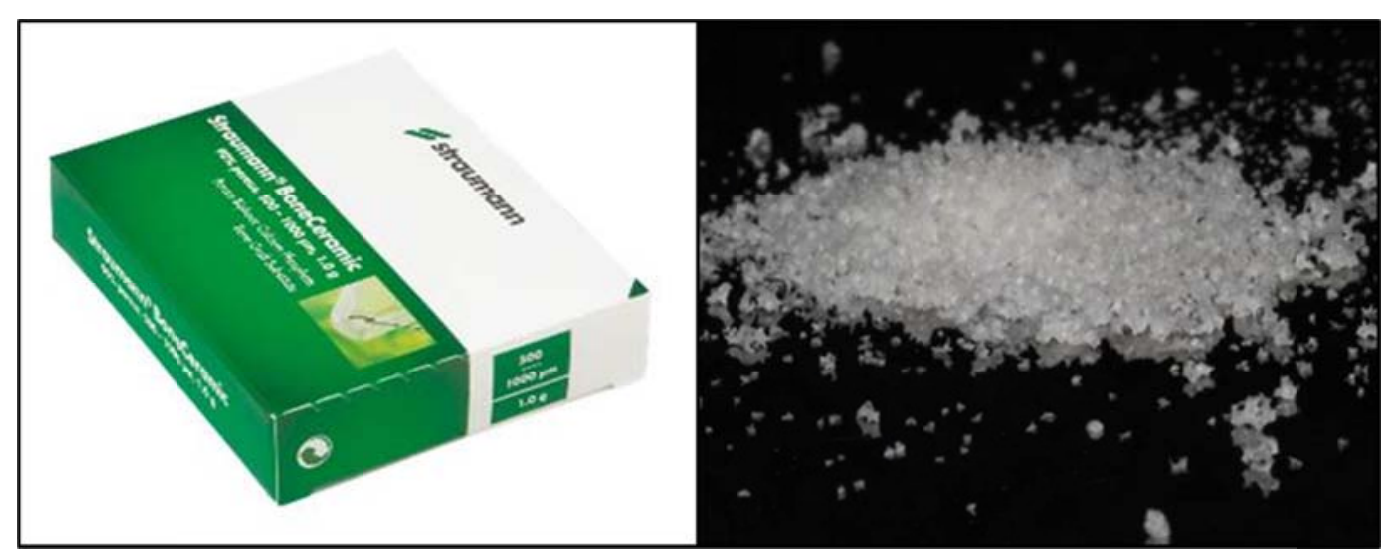

Figura 1: Apresentação comercial e grânulos da biocerâmica (Straumann ${ }^{\circledR}$ BoneCeramic).

\subsection{CULTURA DE CÉLULAS DE MEDULA ÓSSEA DE RATOS}

As células de medula óssea de ratos foram obtidas utilizando o método descrito por Maniatopoulos et al. (1988) através de procedimentos realizados no Laboratório de Cultura de Células de Faculdade de Odontologia de Ribeirão Preto da Universidade de São Paulo. 06 Ratos jovens variedade Wistar com cinco semanas de idade e pesando entre 100-120 gramas foram sacrificados e mergulhados em solução de álcool iodado $1 \%$. Foi realizada antissepsia com clorexidina $2,5 \%$ e gaze esterilizada. Os fêmures foram removidos utilizando campos e instrumentos cirúrgicos esterilizados e armazenados em tubos de vidro de $25 \mathrm{ml}$ com tampa rosqueável contendo $15 \mathrm{ml}$ de meio de lavagem ( $\alpha$-MEM, fungizone e gentamicina, Gibco). Os fêmures foram transportados até a capela de fluxo laminar, lavados com álcool 70\% e clorexidina 2,5\% (1 minuto cada) em placas de Petri. Após este procedimento, foram realizadas três lavagens (remoção de excesso de tecido mole utilizando lâminas de bisturi nº 15) e uma lavagem em meio total suplementado, que induz a diferenciação de células tronco em osteoblastos ( $\alpha$-MEM - Gibco), soro fetal bovino (Gibco), dexametasona (Sigma), ácido 
ascórbico (Gibco) e $\beta$-glicerofosfato (Sigma), segundo, Pittenger et al. (1999), Rosa et al. (2003). Os meios estavam aquecidos a $37^{\circ} \mathrm{C}$. Em seguida foram cortadas as epífises dos fêmures com tesoura de ponta romba e a medula óssea lavada utilizando seringa de $20 \mathrm{ml}$ e agulha contendo MTS para coleta em tubos de centrífuga de $50 \mathrm{ml}$ (1 tubo para cada fêmur). A suspensão de células foi então transferida para garrafas de $75 \mathrm{~cm}^{3}$ contendo $20 \mathrm{ml}$ de MTS. As garrafas foram armazenadas em uma incubadora a $37^{\circ} \mathrm{C} \mathrm{e}$ atmosfera umidificada com $5 \%$ de $\mathrm{CO}_{2}$ e $95 \%$ de ar atmosférico. Após a confluência, as células foram removidas dos frascos de cultura por meio de EDTA 1mM (Gibco) e tripsina 0,25\% (Gibco) e contadas utilizando um hemocitômetro para implantação nos defeitos ósseos (Figura 2).

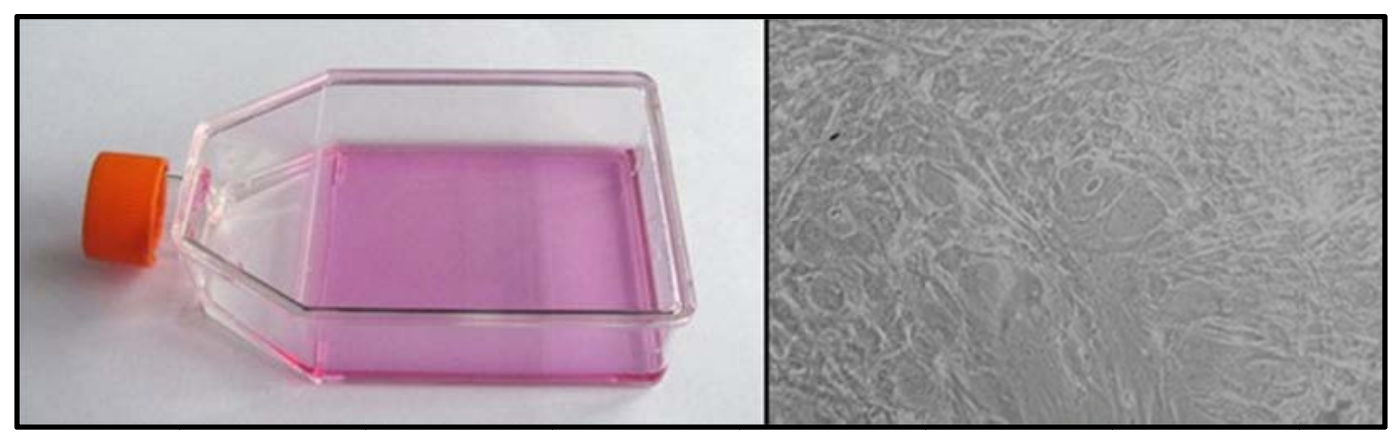

Figura 2: Garrafa contendo células osteoblásticas em MTS, e cultura ao microscópio de fase (40X).

\subsection{EXTRAÇÃO DENTÁRIA}

Todos os animais foram anestesiados com 2,2,2 Tribiromoetanol (SigmaAldrich, St. Louis, MO, USA) administrado por via intraperitoneal, na dose de 25 $\mathrm{mg} / 100$ gramas de peso corporal.

Sob condições apropriadas de desinfecção e após a sindesmotomia da gengiva circundante e luxação os incisivos superiores direitos foram extraídos. Em 
seguida os tecidos moles foram suturados (Figura 3) com fio mononylon 4.0 (Ethicon, São José dos Campos, SP, Brasil) e os animais receberam 0,2 ml de injeção intramuscular de Pentabiótico Veterinário, em dose única (Wyeth-São Bernardo do Campo, SP, Brasil).

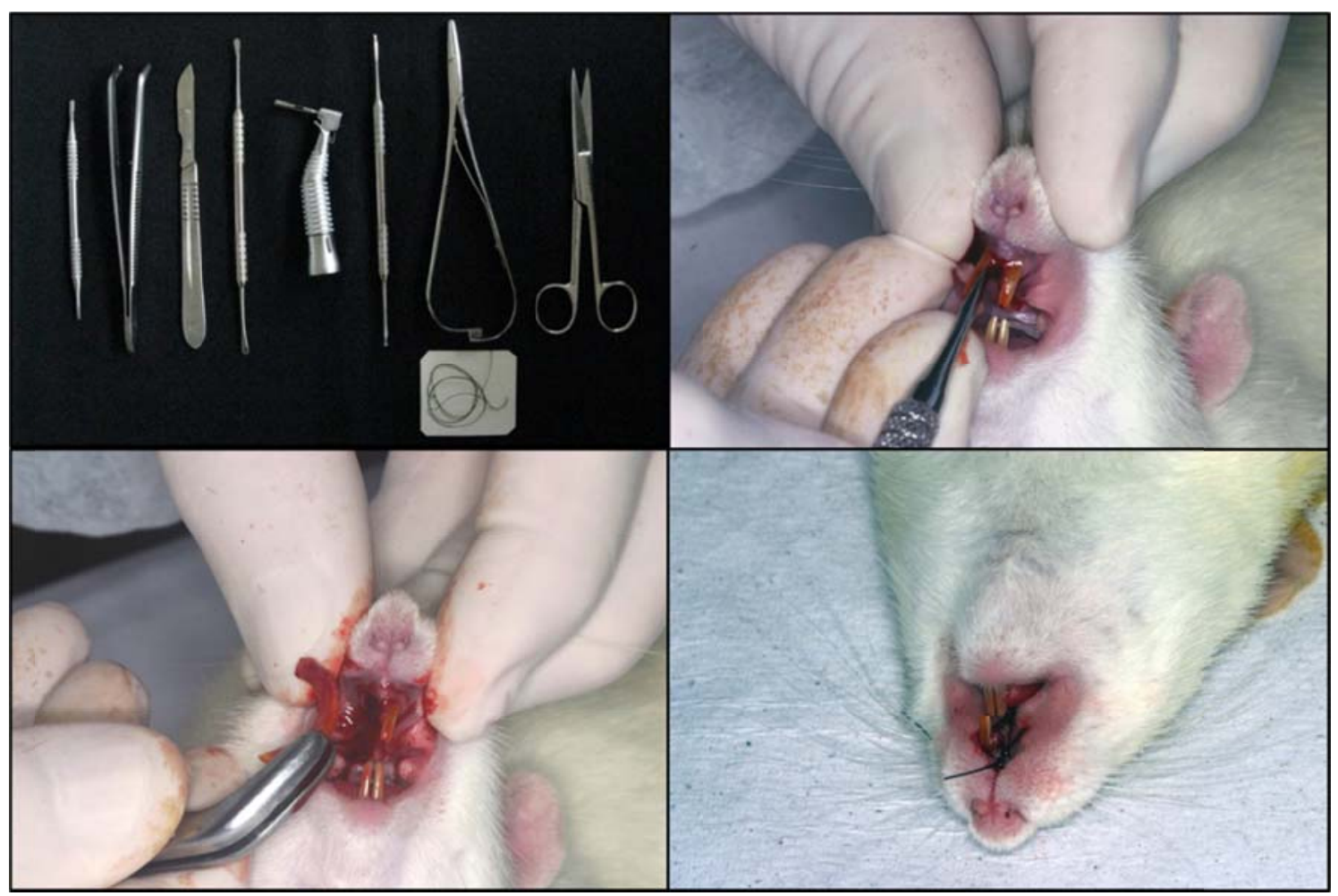

Figura 3: Procedimento cirúrgico de extração dentária.

\subsection{COLETA DO OSSO AUTÓGENO}

Foi realizada tricotomia, e antissepsia da área a ser operada (porção superior da cabeça) com solução de polivinilpirrolidona iodo a 10\%. Em seguida foi feita uma incisão no plano sagital do crânio com lâmina de bisturi 15C respeitando os planos anatômicos, pele e periósteo, seguido pelo descolamento de um retalho de espessura total do lado direito até o arco zigomático, a fim de visualizar a área doadora. Uma trefina de 5,0 $\mathrm{mm}$ de diâmetro (Neodent, Curitiba, PR, Brasil) foi 
utilizada para a osteotomia do osso parietal sob abundante irrigação com $\mathrm{NaCl}$ a $0,9 \%$, seguido pela remoção do fragmento ósseo com cinzel Micro Ochsenbein $n^{\circ} .01$ (Millennium Golgran, Pirituba, SP, Brasil). A ferida cirúrgica foi então suturada com fio mononylon 4.0 (Ethicon, São José dos Campos, SP, Brasil). Subsequentemente este osso foi temporariamente imerso em solução salina ou células osteoblásticas, de acordo com o grupo a que pertencia, fracionado em fragmentos menores antes da implantação no local receptor (Figura 4).

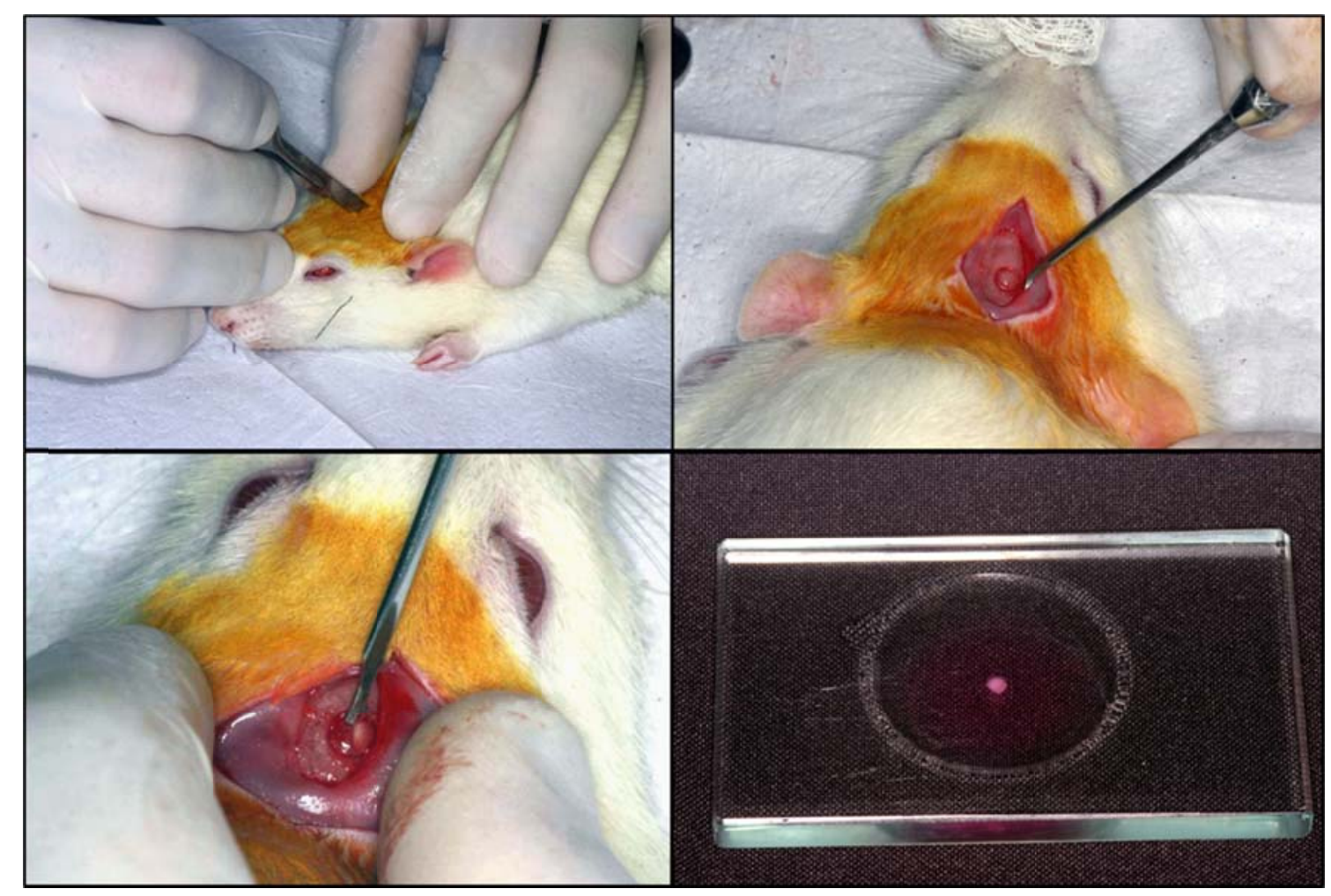

Figura 4: Procedimento cirúrgico para remoção de enxerto da calota craniana.

\subsection{SEMEADURA DAS CÉLULAS NO CARREADOR}

Uma quantidade de aproximadamente $20,0 \mathrm{mg}$ da biocerâmica foi colocada dentro de tubos ependorfs estéreis, e em seguida $1,0 \mathrm{ml}$ da solução de células osteoblásticas já processadas, contendo uma quantidade equivalente a $3,3 \times 10^{5}$ 
células foram pipetadas para o interior dos tubos e a associação biocerâmica/células osteoblásticas foi centrifugada a 2000 RPM durante 5 minutos em uma temperatura de $24^{\circ} \mathrm{C}$, com o objetivo de inserir as células nas porosidades do material. Em seguida, a associação contida nos tubos foi mantida em gelo até o momento da implantação cirúrgica nos animais.

\subsection{IMPLANTES DOS BIOMATERIAIS}

Nos grupos 3 e 4 , tratados apenas com as células osteoblásticas ou estas associadas ao osso autógeno respectivamente, foram inseridas no alvéolo dentário com o auxílio de uma pipeta automática calibrada a injetar $50 \mu \mathrm{l}$, de uma suspensão celular mais concentrada contendo uma quantidade de $3,3 \times 10^{5}$ células em meio de cultura (Figuras 5).

Os fragmentos ósseos retirados da calvária foram recortados com cinzel Micro Ochsenbein nº 01 (Millennium Golgran, Pirituba, SP, Brasil) em tamanho de aproximadamente 1,0 x 2,0 mm. Após nova imersão em solução salina (Grupo 2) e células osteoblásticas (Grupo 4), foram implantados no terço médio dos alvéolos dentários com o auxílio de uma pinça de ponta fina (Figura 6). Logo em seguida ao procedimento os alvéolos foram suturados para assim manter o material confinado ao defeito ósseo.

Nos grupos onde a biocerâmica foi implantada, uma quantidade de aproximadamente $20,0 \mathrm{mg}$ do biomaterial foi inserido na porção média e cervical do alvéolo dentário (Grupos 5 e 6) com o auxílio de um mini porta-amálgama (Figura 7). Para o grupo 7, o mesmo procedimento acima foi realizado exceto que antes da implantação cirúrgica, os tubos ependorfs contendo associação células 
osteoblásticas/biocerâmica para cada animal foram retirados do gelo e o biomaterial contido no interior foi inserido no alvéolo dentário também com a ajuda do mini portaamálgama (Figuras 7).

A inserção do osso autógeno, biocerâmica e células osteoblásticas associados (Grupo 8), também seguiram os mesmos protocolos trans-cirúrgicos como descrito para os grupos explanados acima. Sendo que primeiro o osso autógeno foi acondicionado no alvéolo e em seguida o composto células osteoblásticas/biocerâmica.

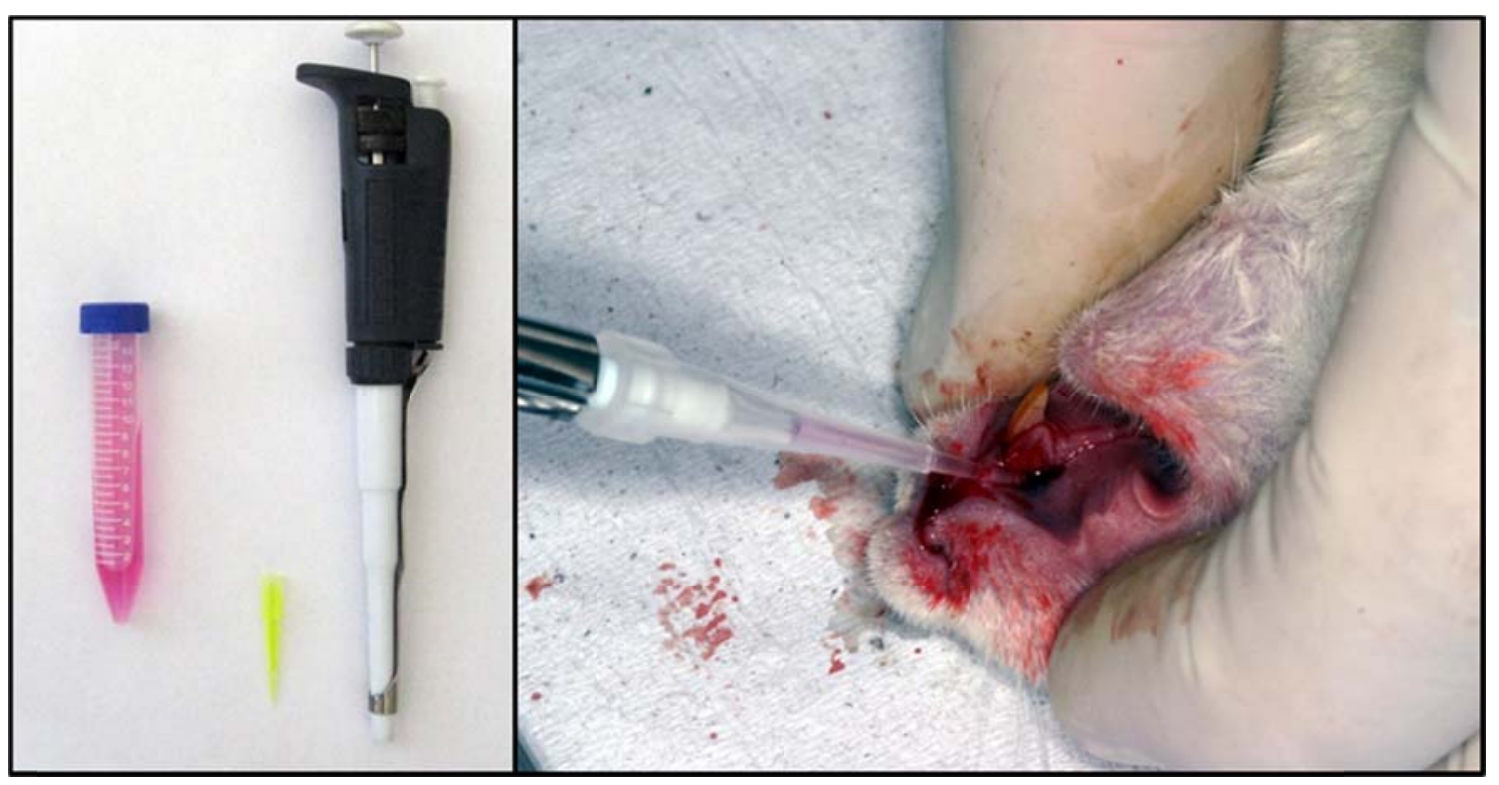

Figura 5: Pipeta e implantação das células osteoblásticas no alvéolo.

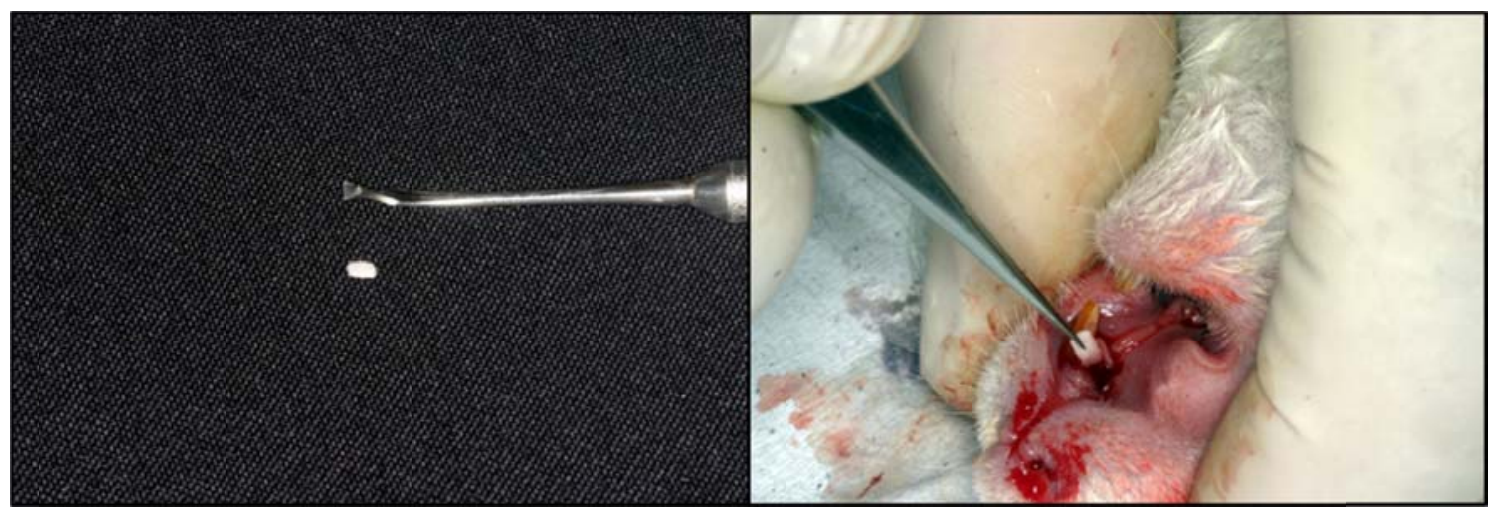

Figura 6: Fragmento de osso autógeno recortado, e implantação no alvéolo. 


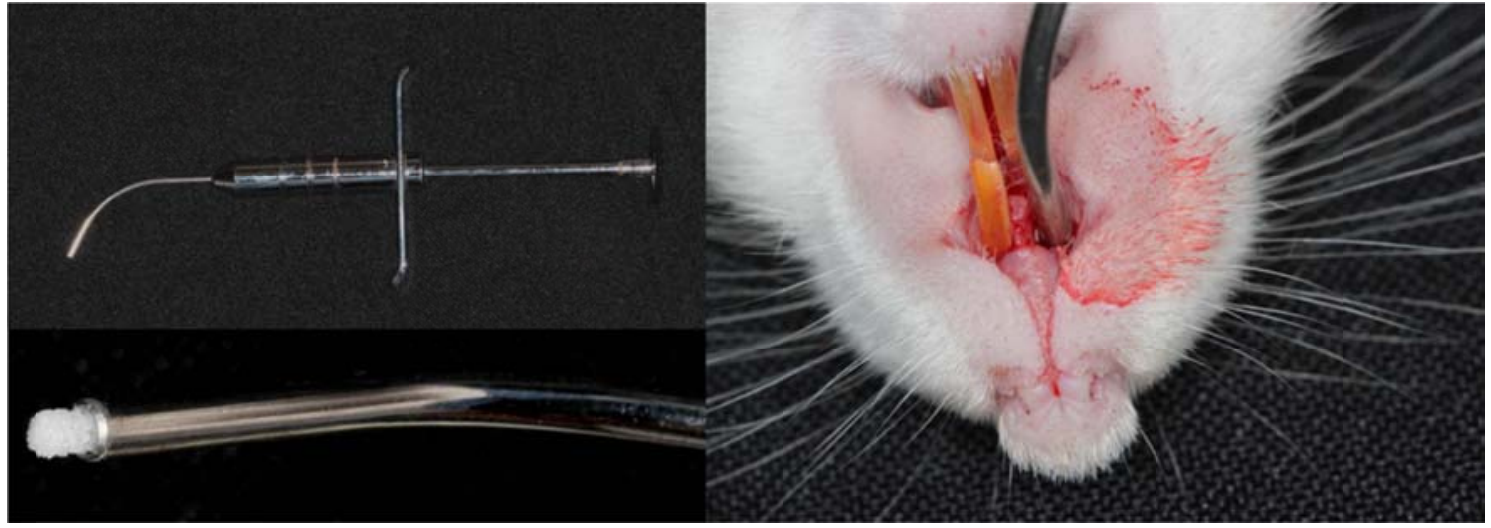

Figura 7: Mini porta-amálgama com a biocerâmica e implantação no alvéolo dentário.

\subsection{SACRIFÍCIO E COLETA DO MATERIAL}

O sacrifício ocorreu por uma sobredose do mesmo anestésico no $7^{\circ}, 21^{\circ} \mathrm{e}$ $42^{\circ}$ dias após a extração ( $n=5$ por grupo). As mandíbulas foram separadas das maxilas com o auxílio de uma tesoura, e a maxila direita foi separada da esquerda através de uma incisão ao nível do plano sagital mediano acompanhando a sutura intermaxilar utilizando uma lâmina de bisturi. Um corte com tesoura reta tangenciando a face distal dos molares possibilitou a obtenç:ão da peça com o alvéolo dentário direito (Figura 8). 


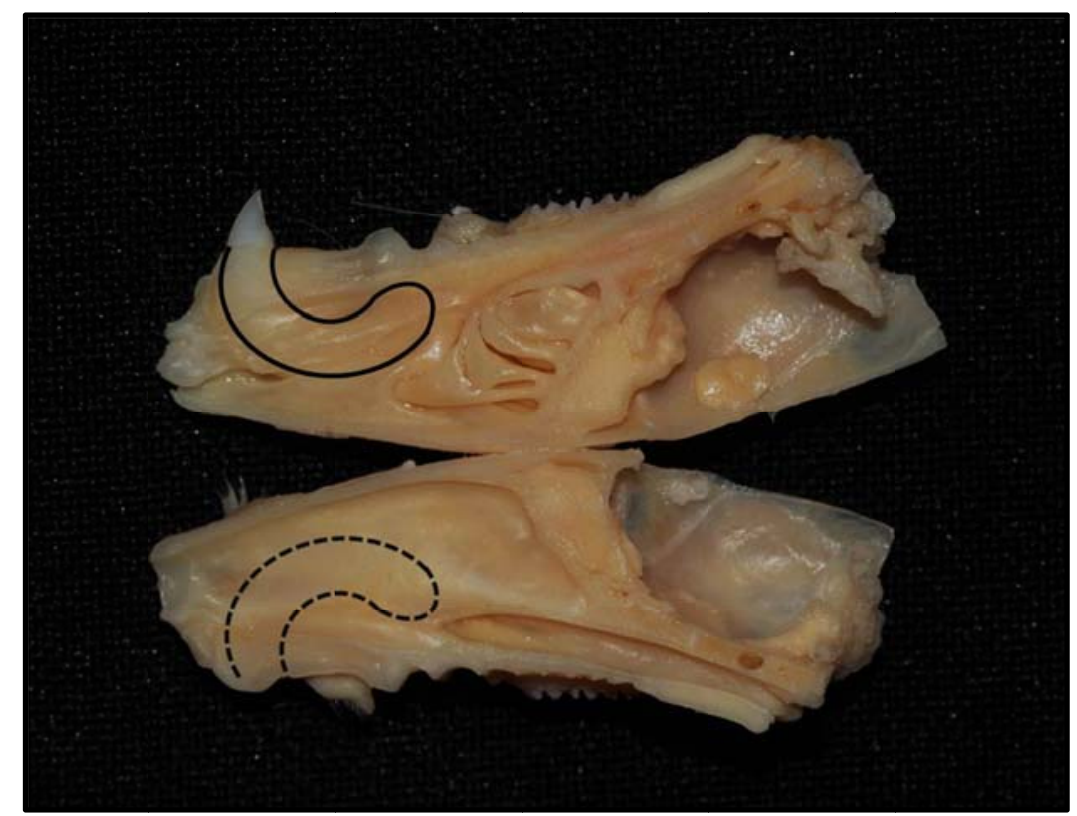

Figura 8: Peças da hemi-maxila direita contendo a representação esquemática do alvéolo somente (linha pontilhada) e hemi-maxila esquerda com o dente incisivo (linha cheia).

\subsection{PROCEDIMENTO HISTOLÓGICO}

As hemi-maxilas direitas foram imersas em formol a $10 \%$ para fixação, descalcificadas por 4 dias em solução de citrato de sódio a $20 \%$ e ácido fórmico a 30\% (MORSE, 1945), lavadas por 24 horas em água corrente, desidratadas, diafanizadas, incluídas em parafina e orientadas de maneira a permitir cortes longitudinais de 5 micrometros de espessura, corados pela hematoxilina-eosina. Foram obtidos 20 cortes distanciados um do outro por um intervalo de $50 \mu \mathrm{m}$.

\subsection{PROCESSAMENTO DAS AMOSTRAS PARA MICROSCOPIA ELETRÔNICA DE VARREDURA}

Uma amostra tecidual da hemi-maxila foi obtida de cada grupo onde a biocerâmica foi implantada (Grupos 5, 6, 7 e 8) para os períodos de 21 e 42 dias, 
seguido pela fixação química das mesmas em formaldeído (10\%) em temperatura ambiente. As amostras fixadas foram recortadas em tamanho apropriado utilizando um disco diamantado dupla face (KG Sorensen, Cotia, SP, Brasil) em 25000 rotações por minuto montado em peça reta para cirurgia óssea sob intensa irrigação com solução de formaldeído a $10 \%$, de modo que foram obtidas secções transversais de aproximadamente $0,8 \times 0,5 \mathrm{~cm}$ da peça contendo o alvéolo dentário com o biomaterial. Após o corte, as peças foram lavadas em tampão fosfato de sódio $0.1 \mathrm{M}$ e $\mathrm{pH} 7.4$ por 2 horas a $4^{\circ} \mathrm{C}$, a seguir foram submetidas a um processo de desidratação em bateria alcoólica de concentração crescente (etanol PA - Merck) de: $30^{\circ}, 50^{\circ}, 70^{\circ}, 90^{\circ}, 95^{\circ} \mathrm{GL}$ - 15 minutos em cada concentração e $100^{\circ} \mathrm{GL}$, com 3 passagens de 20 minutos em um Critical Point Dryer, modelo CPD - 030 (Baltec). Posteriormente, as amostras foram fixadas a um cilindro de metal para observação no microscópio eletrônico (stub) com cola Silver Print (Baltec) e recobertas com o ouro 24K em um Sputter Coater, modelo SCD - 050 (Baltec). As observações e eletronmicrografias foram realizadas em um Microscópio Eletrônico de Varredura Jeol JSM - 6610LV (Japão), e registradas digitalmente com ampliações que variaram de 22 a 12000 vezes. Estes procedimentos foram realizados no Laboratório de Microscopia Eletrônica do Departamento de Biologia Celular e Molecular da Faculdade de Medicina de Ribeirão Preto da Universidade de São Paulo.

\subsection{ANÁLISE HISTOMORFOMÉTRICA DOS ALVÉOLOS}

Para facilitar o estudo, o alvéolo foi dividido em três terços: apical, médio e cervical. Utilizou-se para análise quantitativa dos tecidos um microscópio óptico Leica DM LB2 (Leica Microsystems Wetzlar GmbH, Wetzlar Germany). As imagens 
foram capturadas através de uma câmara digital de vídeo Leica DFC 280 (Leica Microsystems Imaging AG, Cambridge, England), utilizando uma objetiva com aumento de 20X que foram introduzidas em computador com o auxílio de um software de captura e análise de imagens Leica Owin (Leica Imaging Systems Ltd, Cambridge, England). As imagens foram analisadas obtendo-se a fração de volume (\%) do osso trabecular neoformado, biocerâmica, tecido conjuntivo e coágulo sanguíneo no interior do alvéolo.

Os cortes histológicos foram focalizados ao microscópio com objetiva de 20x e em cada alvéolo foram analisados 15 campos microscópicos (5 no terço apical, 5 no médio e 5 no cervical), mediante a utilização de uma grade colocada sobre os cortes (Figura 9).

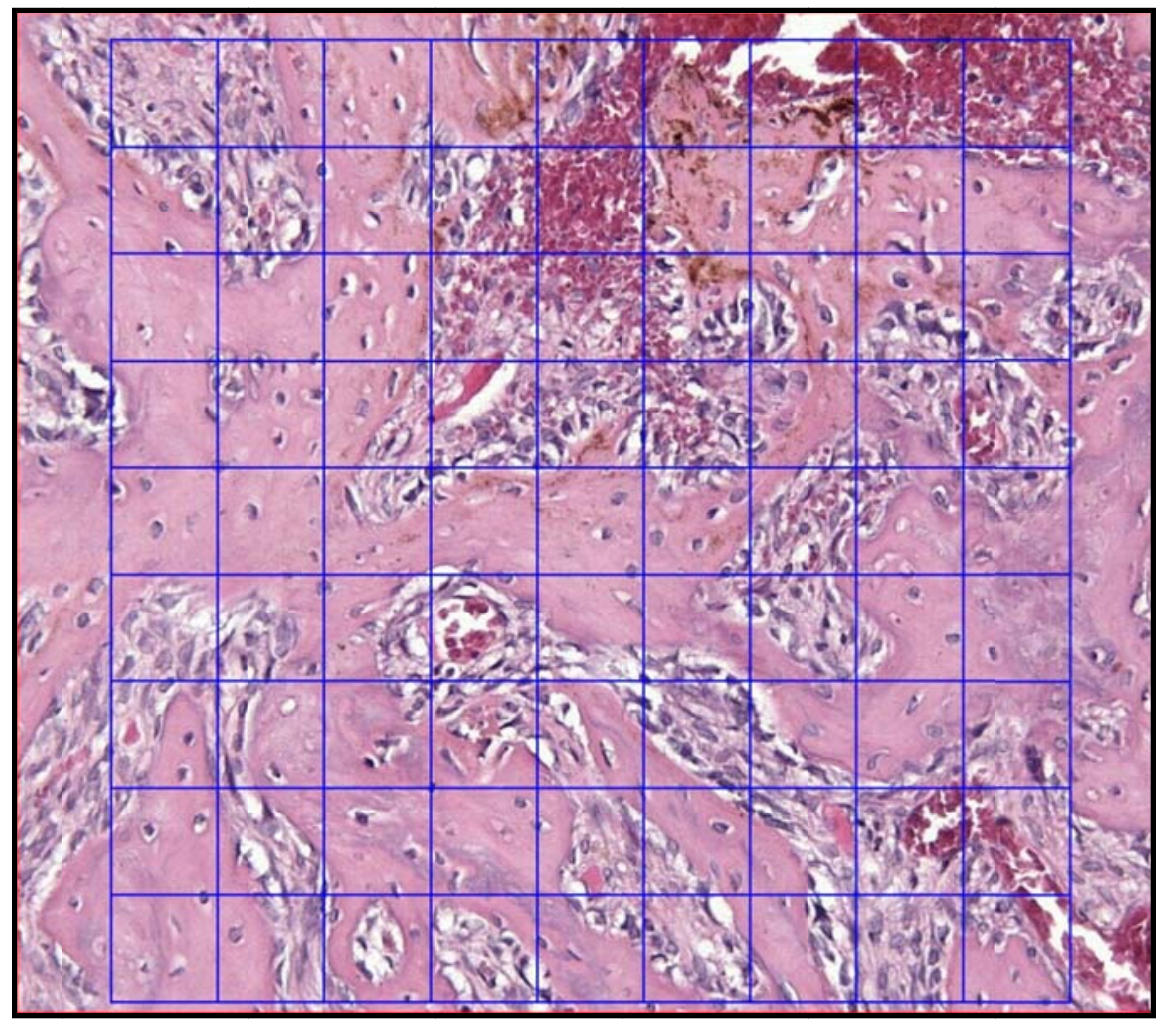

Figura 9: Grade 
Essa grade consiste de um quadrado que limita a área teste, contendo 100 cruzamentos das linhas que pode ser utilizada para contar pontos, sobre uma determinada estrutura histológica. Conhecida a área coberta pela grade foi possível estimar a densidade volumétrica do tecido ósseo, material implantado, tecido conjuntivo e coágulo sanguíneo nos diferentes períodos do estudo pela contagem de 1500 pontos por alvéolo analisado, correspondente ao produto de 5 campos microscópicos por terço, por 100 pontos (cruzamentos).

A fração de volume das diferentes estruturas foi estimada seguindo a fórmula da densidade volumétrica (Dv)

$$
\mathrm{Dv}=\underline{\mathrm{Pe}} \times 100
$$

$\mathrm{Pt}$

$\mathrm{Pe}=$ pontos na estrutura; $\mathrm{Pt}=$ pontos totais

\subsection{ANÁLISE EM MICROSCOPIA ELETRÔNICA DE VARREDURA}

Através da microscopia eletrônica de varredura, foi observada a relação da interface entre o material cerâmico implantado (Straumann ${ }^{\circledR}$ BoneCeramic) com o tecido ósseo e conjuntivo adjacente. O objetivo foi observar qualitativamente a biocompatibilidade e a osseointegração do material e o comportamento do organismo frente ao implante intra-alveolar.

\subsection{ANÁLISE ESTATÍSTICA}

As comparações entre os resultados dos grupos foram realizadas pelos testes estatísticos paramétricos ANOVA e Tukey, considerando significantemente diferentes os grupos com $p \leq 0,05$ (Siegel, 1975). 


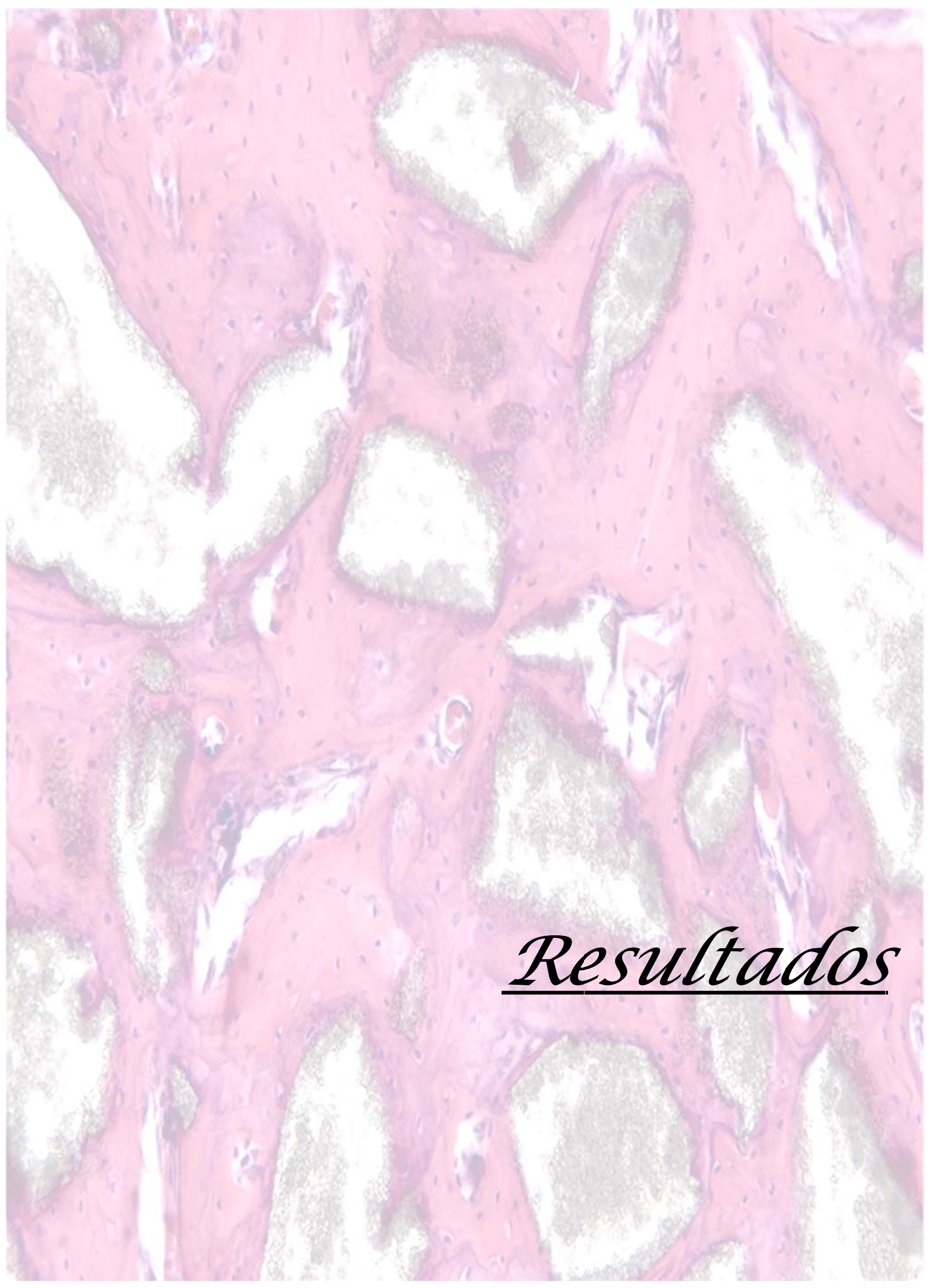




\section{Resultados}

\subsection{RESULTADOS HISTOLÓGICOS EM MICROSCOPIA DE LUZ}

\subsubsection{7 dias}

\section{Grupo controle (C)}

Nos cortes histológicos dos alvéolos dos animais observou-se um preenchimento parcial com tecido conjuntivo cicatricial rico em fibroblastos, capilares e osso neoformado. O alvéolo encontrou-se parcialmente preenchido por delicadas trabéculas ósseas imaturas circundadas por osteoblastos, entremeadas com massas de coágulo em organização (Figura 10A).

\section{Grupo osso autógeno (OA)}

O alvéolo se apresentou parcialmente preenchido por trabéculas ósseas neoformadas bem organizadas e circundadas por osteoblastos, entremeadas em um tecido conjuntivo moderadamente maduro contendo remanescentes de coágulos sanguíneos (Figura 10B). As avaliações histológicas demonstraram a presença do fragmento de osso implantado (Figura 11A), que não foi reabsorvido, localizado no terço médio do alvéolo sem nenhuma reação inflamatória de corpo estranho. $\mathrm{Na}$ superfície do remanescente do implante observou-se uma linha de cimentação que separava o novo tecido ósseo em deposição do antigo (Figura 12A).

\section{Grupo células osteoblásticas (CO)}

Histologicamente a análise do componente tecidual no interior dos alvéolos dentários demonstrou um tecido conjuntivo sendo substituído progressivamente por 
trabéculas ósseas neoformadas com adequado grau de mineralização contendo ainda coágulos sanguíneos no seu interstício. Quanto ao procedimento de enxertia das células osteoblásticas, nenhuma reação tecidual aguda ou de corpo estranho pode ser notada nestes animais (Figura 10C).

Grupo osso autógeno + células osteoblásticas (OA + CO)

A imagem histológica deste grupo mostra um trabeculado de osso neoformado delicado e organizado para o período de 7 dias. Nota-se ainda um tecido conjuntivo maduro com algumas áreas de coágulos sanguíneos (Figura 10D). O enxerto de osso autógeno se mostrou circundado por um tecido conjuntivo sem reações inflamatórias, e na sua superfície trabéculas ósseas neoformadas originando a partir do fragmento implantado (Figura 12B).

\section{Grupo biocerâmica (BC)}

A reparação óssea neste grupo de animais apresentou trabéculas ósseas imaturas, em processo de formação contígua ao material utilizado, contendo ainda tecido conjuntivo com baixas quantidades de coágulos sanguíneos (Figura 10E). A biocerâmica implantada se mostrou distribuída pelos terços médio e cervical do alvéolo dentário, com boa biocompatibilidade, sem a presença de células inflamatórias ao seu redor, e sem provocar reações de corpo estranho. Boa ligação entre as partículas e o tecido ósseo neoformado foi observado (Figura 12C).

\section{Grupo biocerâmica + osso autógeno (BC + OA)}

Os achados histológicos revelaram trabéculas ósseas em processo de formação entre as partículas da biocerâmica e do osso autógeno (Figura 11B), contendo áreas de tecido conjuntivo em processo de amadurecimento associado a coágulos sanguíneos em algumas regiões (Figura 10F). A biocerâmica utilizada 
mostrou justaposição com o tecido ósseo em processo de deposição, sem a presença de reações inflamatórias na superfície. Pode ser notado desenvolvimento de novo tecido ósseo a partir da superfície dos fragmentos de osso autógeno enxertados (Figura 12D).

Grupo biocerâmica + células osteoblásticas $(\mathrm{BC}+\mathrm{CO})$

A análise dos cortes revelou a presença da biocerâmica preenchendo boa parte do alvéolo, em íntimo contato com um tecido ósseo recém-sintetizado, caracterizado por trabéculas imaturas contendo osteoblastos em alta atividade (Figura 10G). O uso das células e da cerâmica bifásica não levou ao desenvolvimento de massas teciduais tumorais, reação de corpo estranho e processo inflamatório agudo persistente. As partículas de HA/ $\beta$-TCP foram biocompatíveis e proporcionaram boas características osteointegradoras (Figura $12 \mathrm{E})$.

Grupo biocerâmica + células osteoblásticas + osso autógeno $(\mathrm{BC}+\mathrm{CO}+\mathrm{OA})$

A associação dos três componentes proporcionou o desenvolvimento de trabéculas ósseas com expressiva maturidade para o período estudado, revelando áreas de densidade e compactação óssea superior aos demais grupos estudados (Figura 10H). Nos fragmentos de osso autógeno observou-se osteogênese por contato, com novas trabéculas partindo da superfície do material para o tecido conjuntivo adjacente. As partículas da biocerâmica mostraram adequada capacidade de formação óssea tanto na sua superfície como nas porosidades, bem como ausência de tecido mole, para o aumento analisado, na interface com o osso recémsintetizado, o que evidencia a ótima osteointegração deste material (Figura 12F). 

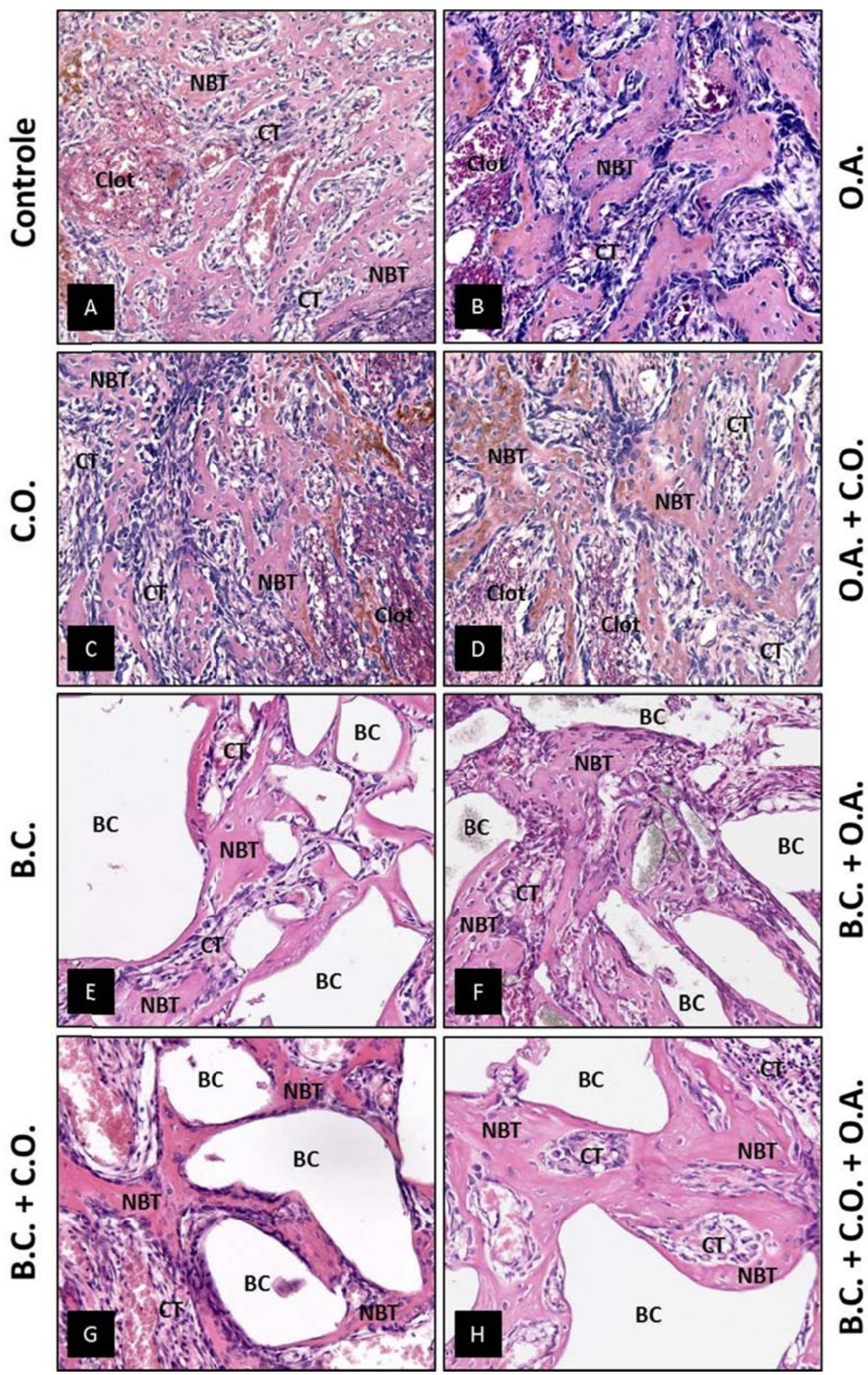

Figura 10: Cortes histológicos do terço médio alveolar dos grupos controle, osso autógeno $(\mathrm{OA})$, células osteoblásticas $(\mathrm{CO})$, osso autógeno + cëlulas osteoblásticas $(\mathrm{OA}+\mathrm{CO})$, biocerâmica $(\mathrm{BC})$, biocerâmica + osso autógeno $(\mathrm{BC}+\mathrm{OA})$, biocerâmica + células osteoblásticas $(\mathrm{BC}+\mathrm{CO})$, e biocerâmica + células osteoblásticas + osso autógeno (BC+CO+OA), 7 dias após a extração dentária. Tecido ósseo neoformado (NBT); Tecido conjuntivo (CT); Coágulo sanguíneo (Clot); Biocerâmica (BC). HE (250x). 

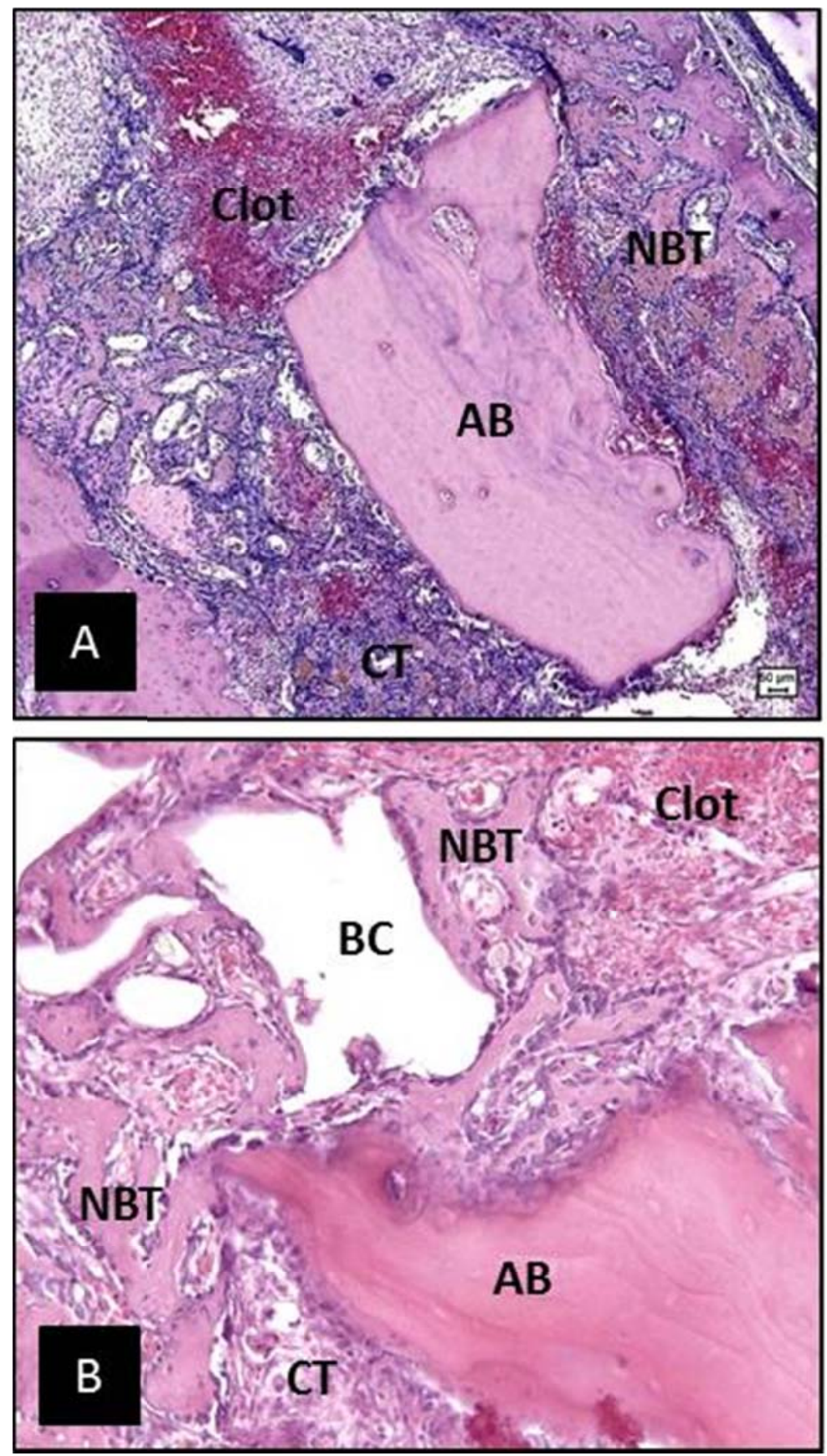

Figura 11: Cortes histológicos demonstrando os biomateriais implantados no interior do terço médio do alvéolo, 7 dias após a extração dentária. Tecido ósseo neoformado (NBT); Tecido conjuntivo (CT); Coágulo sanguíneo (Clot); Osso autógeno (AB); Biocerâmica (BC). HE (A - 62,5x; B - 250x). 

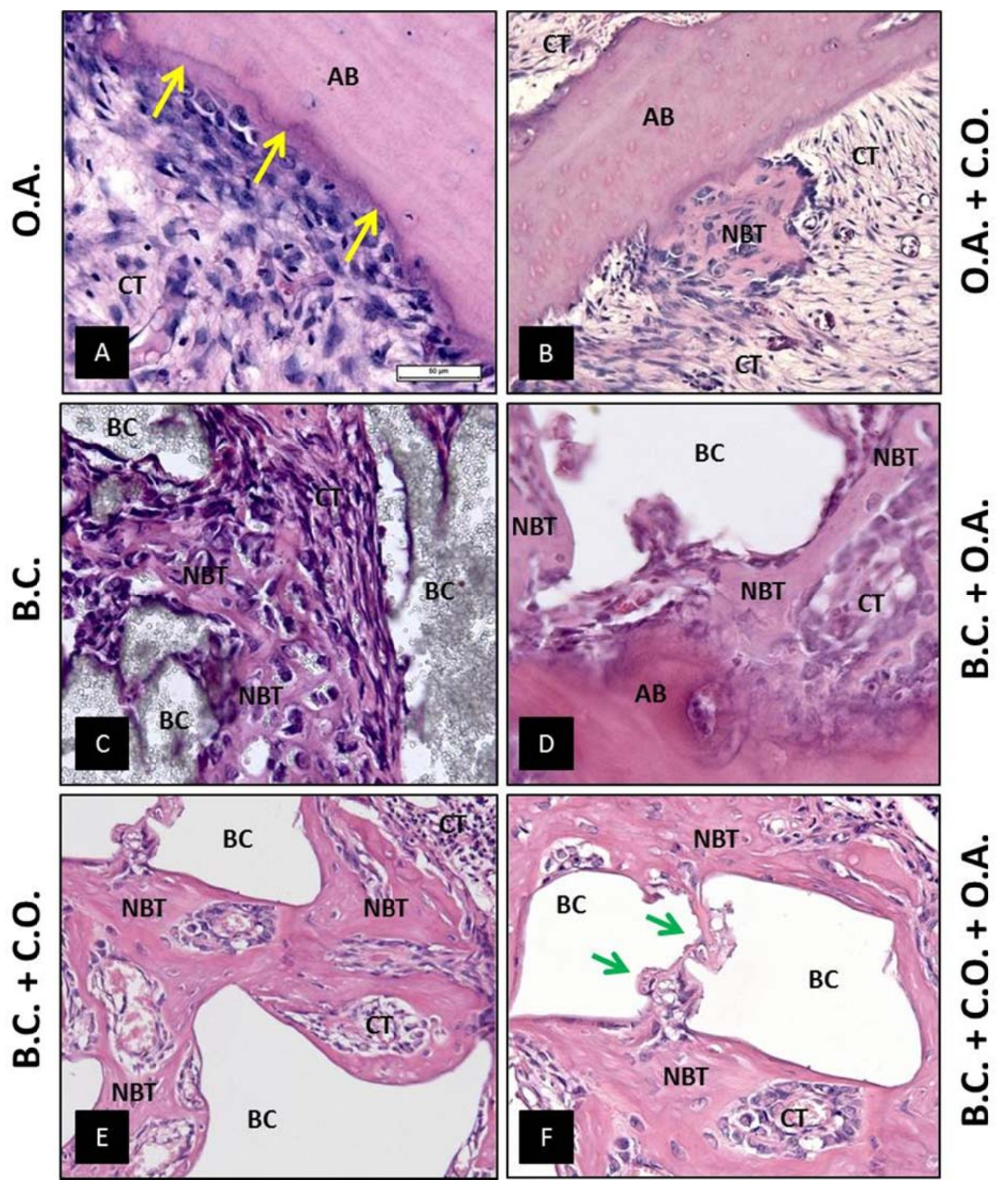

Figura 12: Cortes histológicos demonstrando os detalhes dos fragmentos de osso autógeno e da biocerâmica implantados no alvéolo dentário, bem como a interface com o osso neoformado, 7 dias após a extração dentária. Tecido ósseo neoformado (NBT); Tecido conjuntivo (CT); Coágulo sanguíneo (Clot); Osso autógeno (AB); Biocerâmica (BC); Linha de cimentação (Setas Amarelas); Neoformação óssea na porosidade da biocerâmica (Setas verdes). HE (A, C, D, - 500x; B, E e F - 250x). 


\subsubsection{1 dias}

\section{Grupo controle (C)}

A reparação óssea observada, principalmente nos terços apical e médio dos animais estava composta por trabéculas ósseas mais espessas envolvidas por osteoblastos. A quantidade de tecido conjuntivo se mostrou bem menor do que no período anterior (7 dias) e uma pequena quantidade de coágulo sanguíneo ainda se mostrava em processo de reabsorção (Figura 13A).

\section{Grupo osso autógeno (OA)}

O alvéolo se apresentou preenchido por trabéculas ósseas maduras bem delimitadas e organizadas, juntamente com um tecido conjuntivo maduro com pequenas quantidades de coágulos sanguíneos (Figura 13B). O fragmento de osso autógeno implantado mostrou uma neoformação óssea com trabéculas maduras ao seu redor (Figura 14A) compatível com uma boa osteointegração (Figuras 15A).

\section{Grupo células osteoblásticas (CO)}

A avaliação dos alvéolos dos animais que receberam as células osteoblásticas isoladamente demonstrou um padrão de reparação óssea similar aos animais controle, contendo trabéculas ósseas neoformadas com densidade e maturidade compatível com o período em questão (21 dias). Foi observado tecido conjuntivo com pequenas áreas de coágulos sanguíneos, em processo de reabsorção (Figura 13C).

\section{Grupo osso autógeno + células osteoblásticas (OA + CO)}

Neste período a análise histológica dos alvéolos mostrou um trabeculado de osso maduro circundado por tecido conjuntivo com pequenas áreas de coágulos 
sanguíneos (Figura 13D). O enxerto de osso autógeno se mostrou circundado por trabéculas ósseas em processo de formação. A superfície do fragmento mostrou perfeita união entre o material enxertado e o tecido ósseo neoformado (Figura 15B).

\section{Grupo biocerâmica (BC)}

A análise tecidual deste grupo de animais revelou um tecido ósseo neoformado denso com poucas áreas contendo tecido conjuntivo (Figura 13E). Íntima ligação às partículas da biocerâmica com deposição de material osteóide no interior das porosidades do biomaterial foi evidenciado (Figura 15C).

\section{Grupo biocerâmica + osso autógeno (BC + OA)}

O padrão de reparação óssea neste grupo constou de osso trabecular neoformado contendo osteócitos no seu interior entremeado com áreas de tecido conjuntivo ainda com diminutas áreas de coágulos sanguíneos em processo de substituição por novas fibras colágenas (Figura 13F). O tecido ósseo recém-formado estava em íntima ligação tanto com as partículas da biocerâmica quanto com as de osso autógeno, sem a presença de reações de corpo estranho ou processos inflamatórios crônicos ao redor dos biomateriais utilizados (Figura 15D).

\section{Grupo biocerâmica + células osteoblásticas $(\mathrm{BC}+\mathrm{CO})$}

Os cortes histológicos revelaram trabéculas ósseas com maior grau de compactação e maturidade que no período de 7 dias, com a presença de tecido conjuntivo maduro (Figura 13G). A implantação das células osteoblásticas e da biocerâmica no interior do alvéolo não provocou reações de corpo estranho e imunológica local. O tecido ósseo estava aderido aos grânulos da biocerâmica sem a interposição de tecido mole, demonstrando uma adequada osteointegração (Figura 15E). 


\section{Grupo biocerâmica + células osteoblásticas + osso autógeno $(\mathrm{BC}+\mathrm{CO}+\mathrm{OA})$}

Nos animais onde as células osteoblásticas em conjunto com a biocerâmica e o osso autógeno da calota craniana foram implantados, um padrão de reparação óssea superior aos demais grupos foi observado, pois trabéculas ósseas com densidade e maturidade maior pode ser observado (Figura 13H). As partículas da biocerâmica e algumas do osso autógeno estavam distribuídas principalmente pelos terços médio e cervical do alvéolo, sendo que uma adequada união entre a cortical óssea do alvéolo com os grânulos do BoneCeramic ${ }^{\circledR}$ através do osso recém sintetizado em uma direção centrípeta foi observado (Figura 14B). Justaposição interfacial entre a biocerâmica, o osso autógeno e o osso reparacional caracterizou boa osteintegração destes constituintes (Figura 15F). 

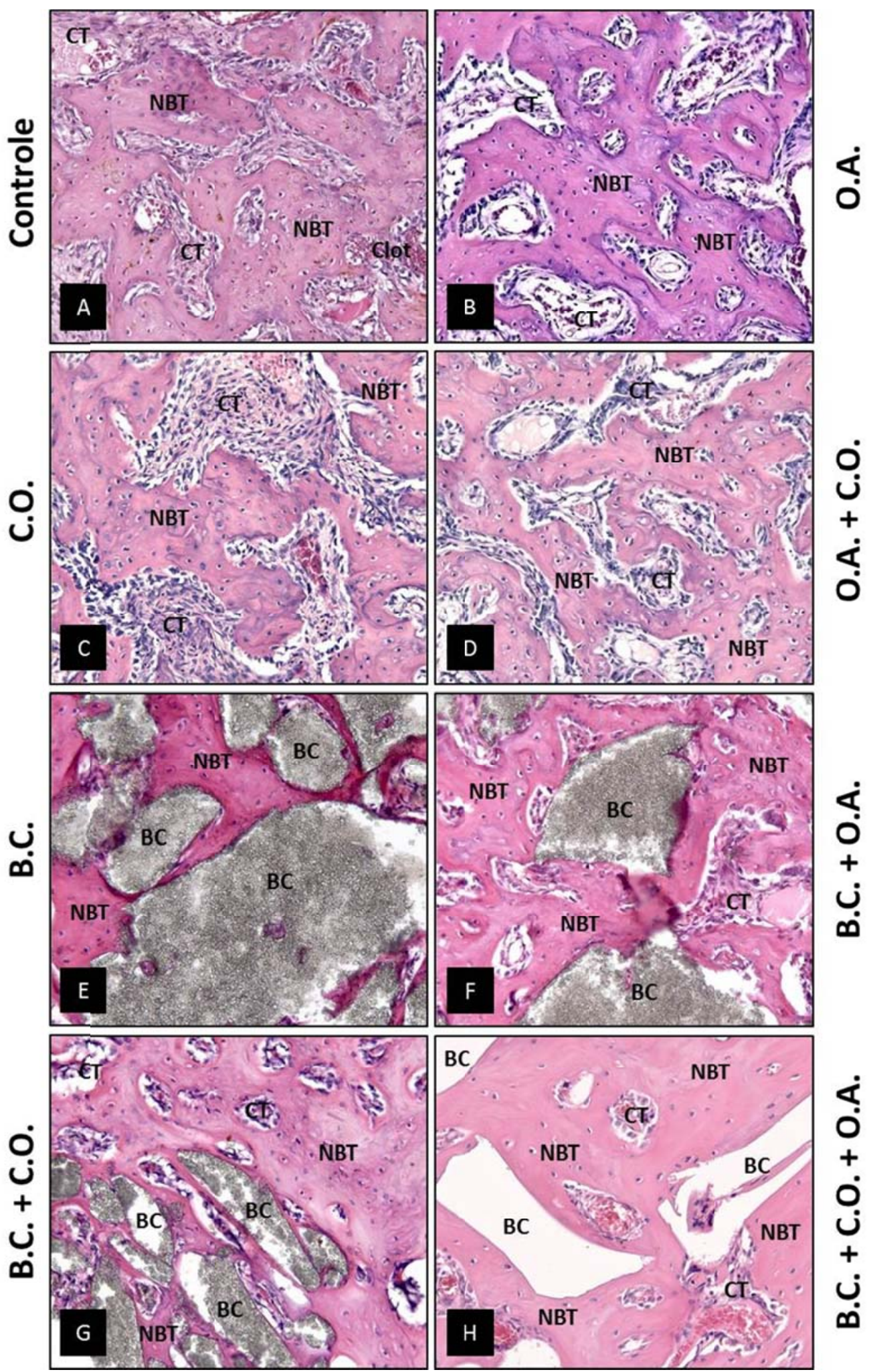

$\dot{4}$
0
+
0
$ن$
+
$\dot{0}$

Figura 13: Cortes histológicos do terço médio alveolar dos grupos controle, osso autógeno $(\mathrm{OA})$, células osteoblásticas $(\mathrm{CO})$, osso autógeno + células osteoblásticas $(\mathrm{OA}+\mathrm{CO})$, biocerâmica $(\mathrm{BC})$, biocerâmica + osso autógeno $(\mathrm{BC}+\mathrm{OA})$, biocerâmica + células osteoblásticas $(\mathrm{BC}+\mathrm{CO})$, e biocerâmica + células osteoblásticas + osso autógeno $(\mathrm{BC}+\mathrm{CO}+\mathrm{OA}), 21$ dias após a extração dentária. Tecido ósseo neoformado (NBT); Tecido conjuntivo (CT); Coágulo sanguíneo (Clot); Biocerâmica (BC). HE. (250x). 

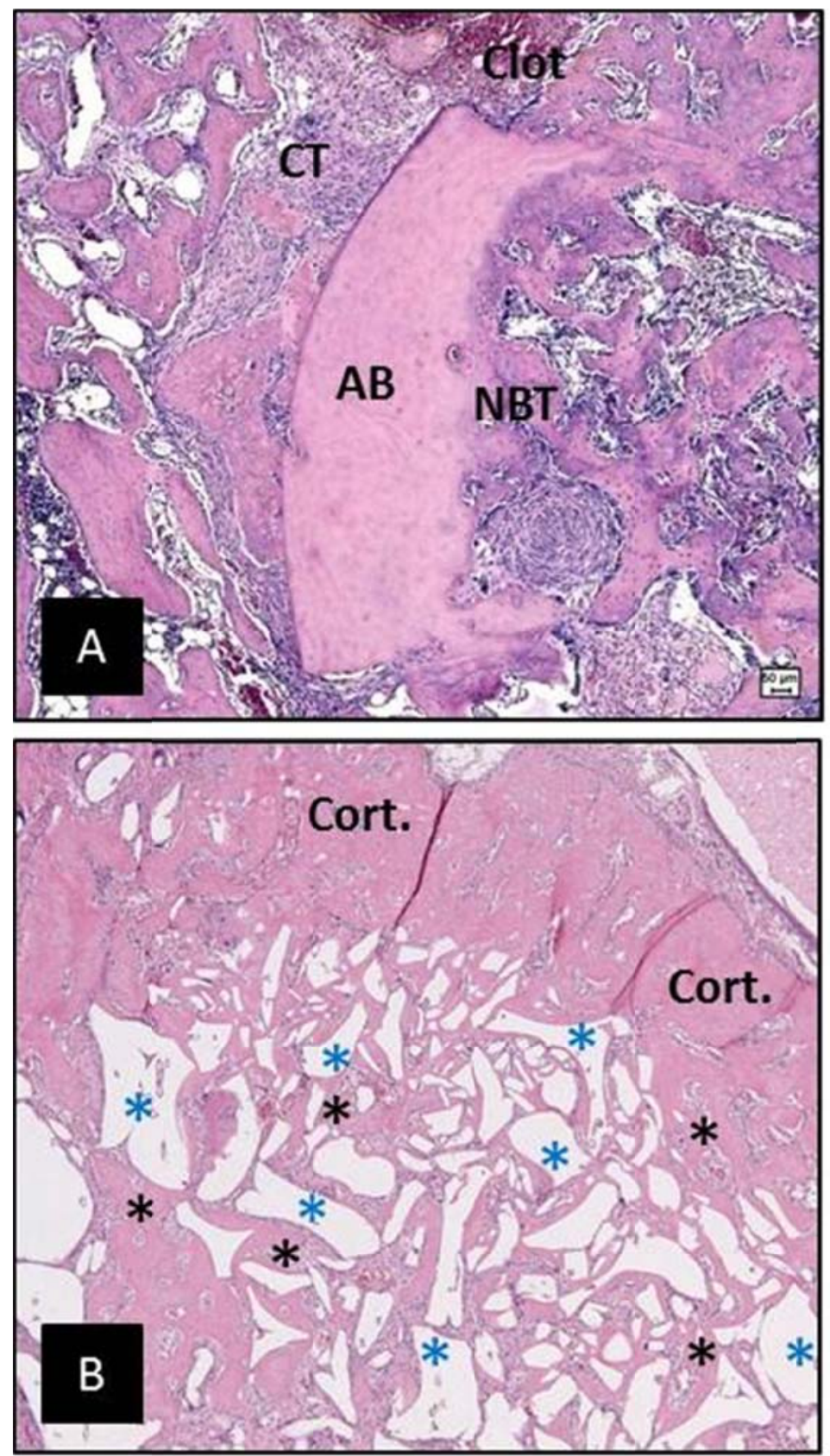

Figura 14: Cortes histológicos demonstrando os biomateriais implantados no interior do alvéolo, 21 dias após a extração dentária. Tecido ósseo neoformado (NBT); Tecido conjuntivo (CT); Coágulo sanguíneo (Clot); Osso autógeno (AB); Biocerâmica (BC); Cortical óssea alveolar (Cort). Partículas de biocerâmica (asterisco azul); Trabéculas ósseas neoformadas (asterisco preto). HE. 62,5x. 

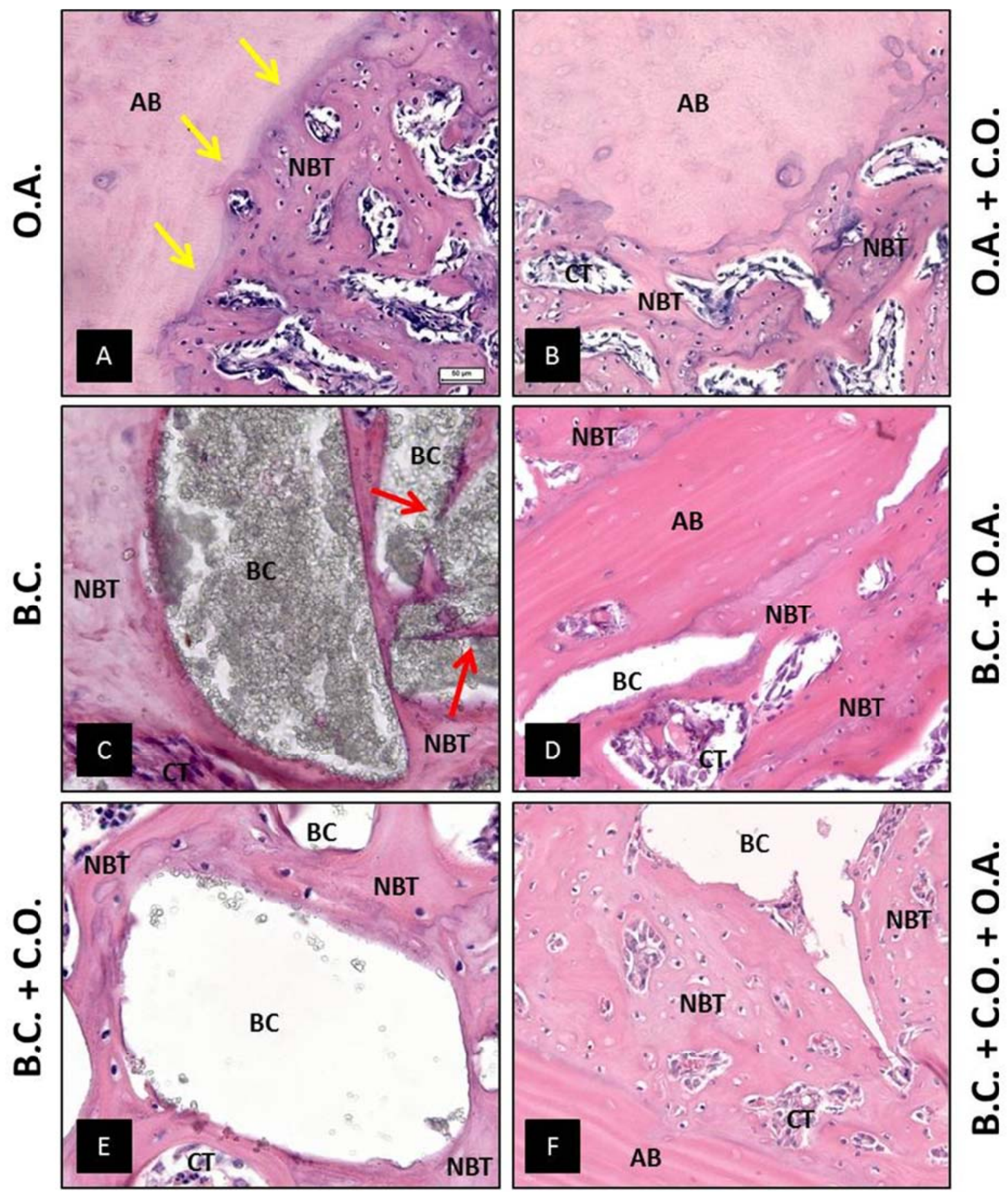

Figura 15: Cortes histológicos demonstrando os detalhes dos fragmentos de osso autógeno e da biocerâmica implantados no alvéolo dentário, bem como a interface com o osso neoformado, 21 dias após a extração dentária. Tecido ósseo neoformado (NBT); Tecido conjuntivo (CT); Osso autógeno (AB); Biocerâmica (BC); Linha de cimentação (Setas amarelas); Neoformação óssea na porosidade da biocerâmica (Setas vermelhas). HE. (C e E - 250x; A, B, D e F - 125x). 


\section{$5.1 .3 \underline{42 \text { dias }}$}

\section{Grupo controle (C)}

A avaliação histológica mostrou um trabeculado ósseo compacto e espesso preenchendo totalmente os alvéolos, entremeado por uma pequena quantidade de tecido conjuntivo maduro (Figura 16A).

\section{Grupo osso autógeno (OA)}

Nestes animais os alvéolos se apresentaram preenchidos por trabéculas ósseas maduras, espessas, bem delimitadas e organizadas, entremeadas em um tecido conjuntivo maduro com quantidades pequenas de coágulos sanguíneos (Figura 16B). O fragmento ósseo da calota craniana enxertado no alvéolo mostrou uma intensa neoformação óssea ao redor de todo o implante (Figura 17A), com uma matriz óssea histologicamente compatível com consolidação e osteointegração (Figuras 18A).

\section{Grupo células osteoblásticas (CO)}

O processo reparacional no alvéolo dentário deste grupo de animais revelou trabéculas ósseas espessas compatíveis com a maturidade do período analisado, entremeadas em um tecido conjuntivo sem a presença de massas teciduais tumorais ou reações inflamatórias (Figura 16C).

\section{Grupo osso autógeno + células osteoblásticas (OA + CO)}

Neste período os alvéolos mostraram na sua grande parte preenchidos por um tecido ósseo espesso, compacto e bem organizado, (Figura 16D). O fragmento de osso autógeno enxertado no terço médio do alvéolo se mostrou totalmente 
envolvido por tecido ósseo reparacional sem nenhuma interposição de tecido mole (Figura 18B).

\section{Grupo biocerâmica (BC)}

A presença de um tecido ósseo espesso com neoformação entre as partículas da biocerâmica e poucas áreas de tecido conjuntivo pode ser observada nos cortes histológicos destes animais (Figura 16E). A biocerâmica apresentou biocompatibilidade e osteointegração, com deposição e maturação óssea na superfície dos grânulos (Figura 18C).

\section{Grupo biocerâmica + osso autógeno (BC + OA)}

Qualitativamente, o processo de reparação óssea alveolar se caracterizou pela presença de trabéculas ósseas maduras e espessas entre os grânulos da biocerâmica e do osso autógeno (Figura 16F). A interface entre o osso autógeno e a biocerâmica com o novo osso depositado revela uma osteointegração efetiva de ambos biomateriais (Figura 18D).

\section{Grupo biocerâmica + células osteoblásticas (BC + CO)}

Neste grupo o processo de reparação do alvéolo dentário progrediu para a formação de trabéculas ósseas espessas entre os grânulos da biocerâmica e espaços medulares diminutos contendo tecido conjuntivo (Figura 16G). Novo tecido ósseo foi capaz de se aderir e amadurecer na superfície do substituto ósseo cerâmico, bem como se desenvolver nas porosidades deste material (Figura 18E). 
Grupo biocerâmica + células osteoblásticas + osso autógeno $(\mathrm{BC}+\mathrm{CO}+\mathrm{OA})$

Histologicamente, a quase totalidade das partículas da biocerâmica e do osso autógeno implantados foram englobadas pelo tecido ósseo reparacional (Figura 17B), demonstrando alta compactação e densidade aliados a áreas de tecido conjuntivo em baixas proporções (Figura 16H). A análise da interface destes biomateriais revelou fusão entre o osso autógeno, biocerâmica e osso neoformado, sem a interposição de tecido mole entre eles, compatível com osteointegração e biocompatibilidade (Figura 18F). 

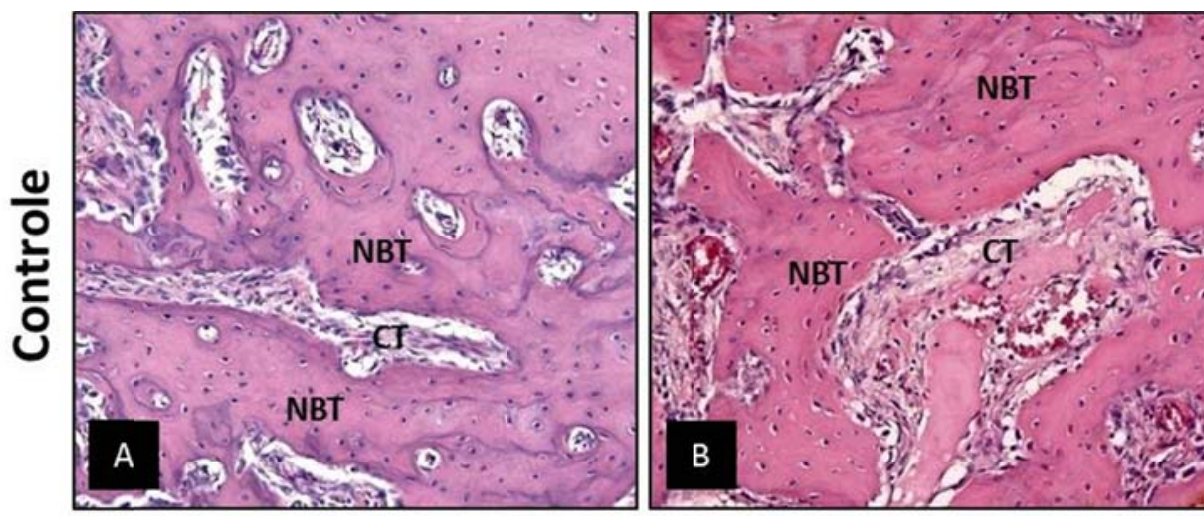

$\stackrel{\dot{c}}{0}$
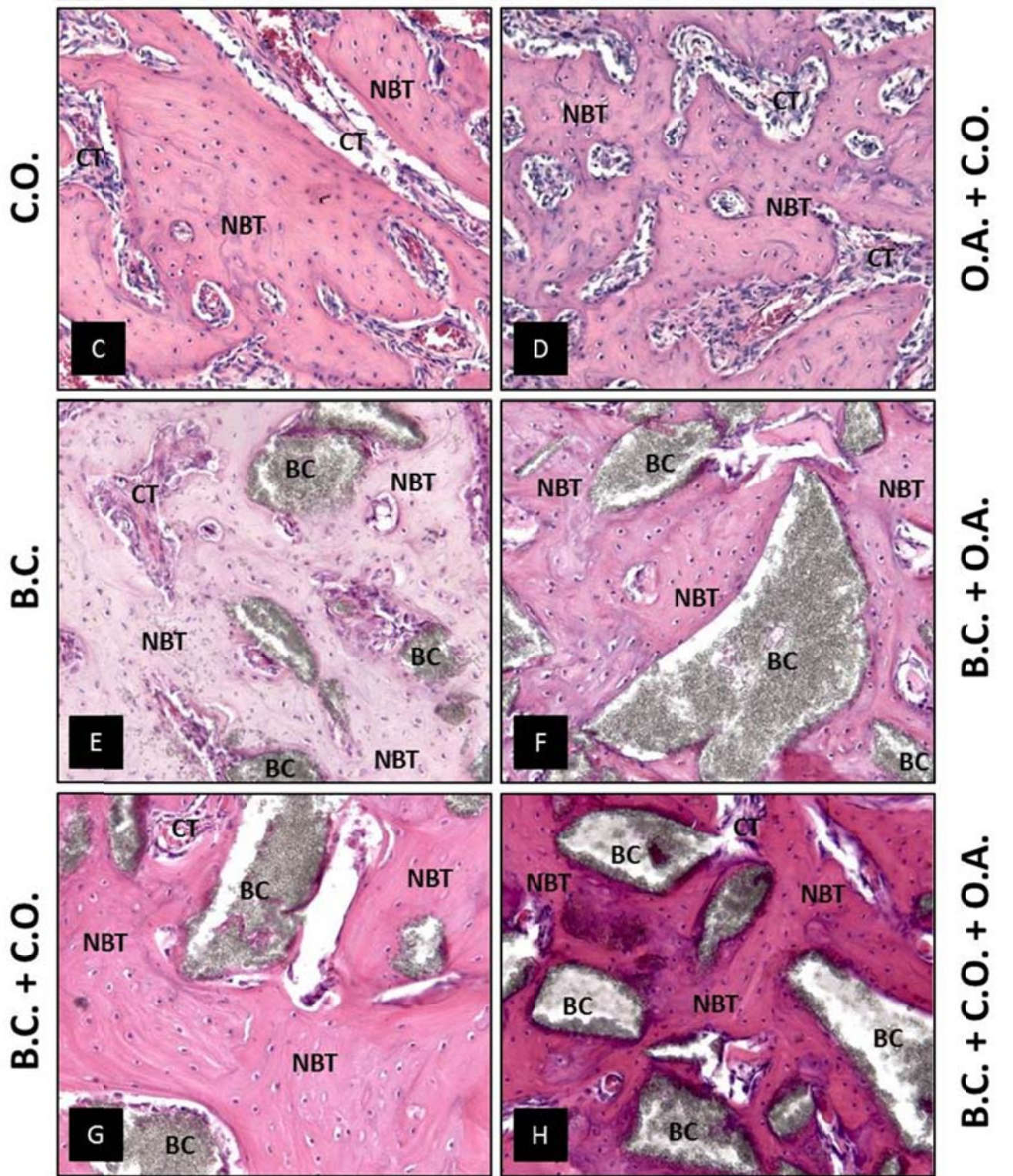

Figura 16: Cortes histológicos do terço médio alveolar dos grupos controle, osso autógeno $(\mathrm{OA})$, células osteoblásticas $(\mathrm{CO})$, osso autógeno + células osteoblásticas $(\mathrm{OA}+\mathrm{CO})$, biocerâmica $(\mathrm{BC})$, biocerâmica + osso autógeno $(\mathrm{BC}+\mathrm{OA})$, biocerâmica + células osteoblásticas $(\mathrm{BC}+\mathrm{CO})$, e biocerâmica + células osteoblásticas + osso autógeno $(\mathrm{BC}+\mathrm{CO}+\mathrm{OA}), \mathbf{4 2}$ dias após a extração dentária. Tecido ósseo neoformado (NBT); Tecido conjuntivo (CT); Biocerâmica (BC). HE, 250x. 

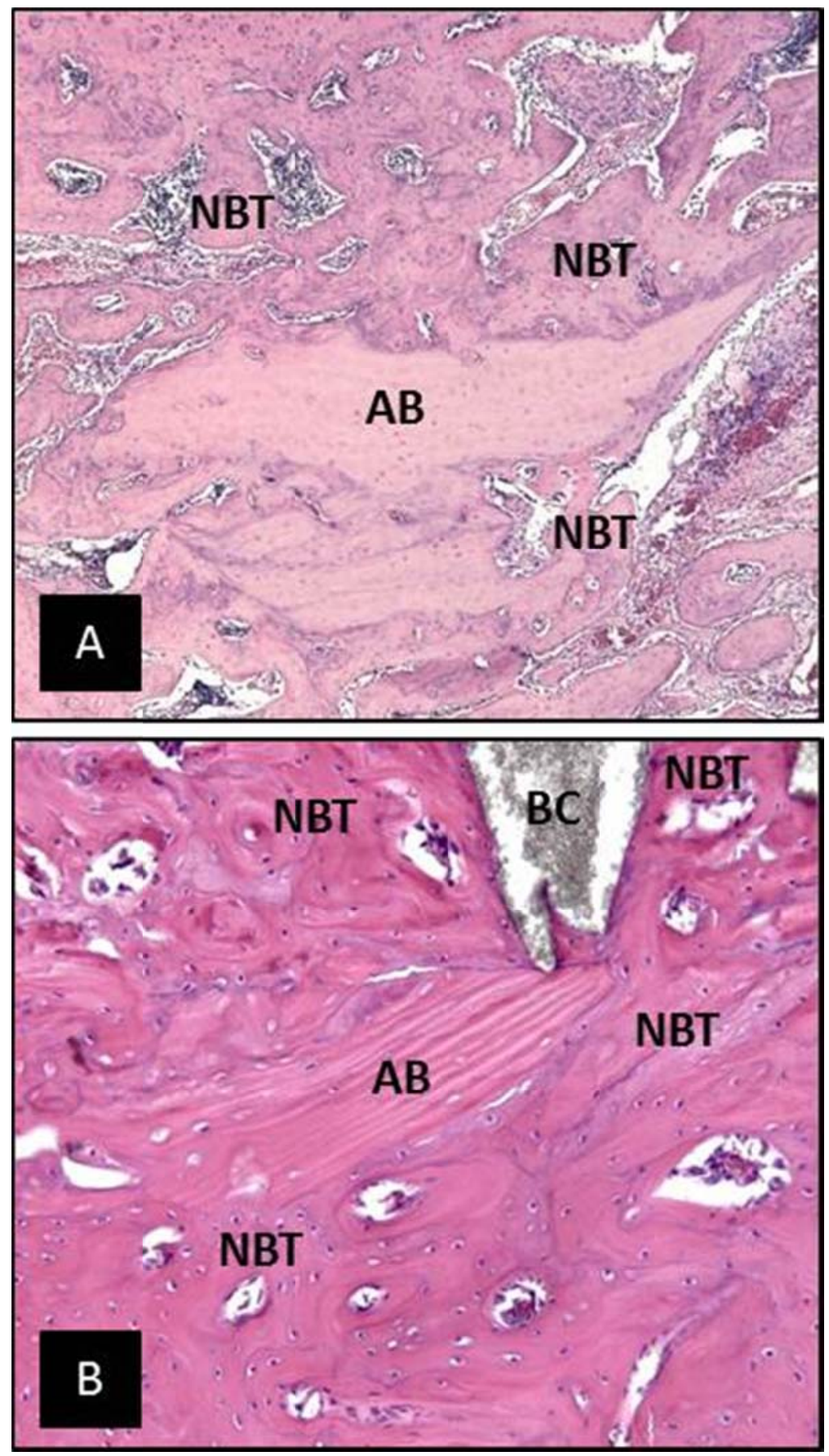

Figura 17: Cortes histológicos demonstrando os biomateriais implantados no interior do alvéolo, 42 dias após a extração dentária. Tecido ósseo neoformado (NBT); Osso autógeno (AB); Biocerâmica (BC). HE. A - 62,5x; B - 125x). 

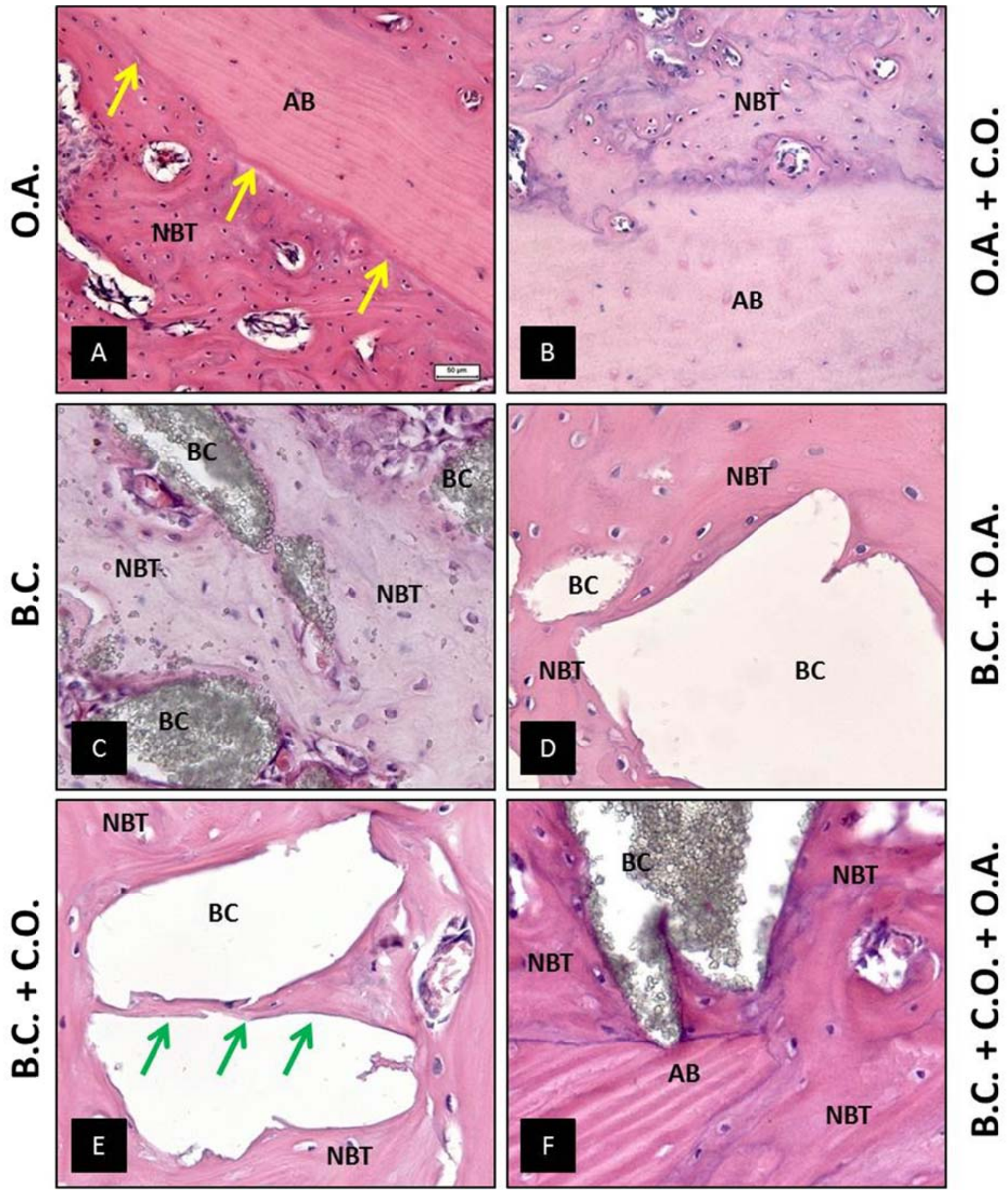

Figura 18: Cortes histológicos demonstrando os detalhes dos fragmentos de osso autógeno e da biocerâmica implantados no alvéolo dentário, bem como a interface com o osso neoformado, 42 dias após a extração dentária. Tecido ósseo neoformado (NBT); Osso autógeno (AB); Biocerâmica (BC); Linha de cimentação (Setas Amarelas); Neoformação óssea na porosidade da biocerâmica (Setas verdes). HE. (500x). 


\subsection{RESULTADOS HISTOLÓGICOS EM MICROSCOPIA ELETRÔNICA DE VARREDURA}

A figura 19A demonstra a superfície da biocerâmica utilizada nesta pesquisa através da microscopia eletrônica de varredura, na qual pode ser observada a grande porosidade inerente a este biomaterial, bem como a homogeneidade geométrica de cada poro. Na figura 19B, um poro em especial é evidenciado com suas dimensões aproximadas (100 a $500 \mu \mathrm{m})$. Em um maior aumento do poro, figura 19C, as interconexões presentes pelo interior da biocerâmica.

A figura 20 demonstra através da microscopia eletrônica de varredura os alvéolos dentários seccionados transversalmente aos 21 e 42 dias após o procedimento cirúrgico de extração do incisivo superior dos animais que receberam a implantação da biocerâmica associada ou isolada. A avaliação qualitativa realizada no $21^{\circ}$ dia revela uma menor área de deposição de osso reparacional compacto (Figura 20A) quando comparado aos animais sacrificados no $42^{\circ}$ dia (Figura 20B).

Aos 21 dias, áreas de tecido conjuntivo puderam ser observadas em contato com a biocerâmica sem a presença de células inflamatórias em grande número, demonstrando boa aceitação por este tecido. As fibras colágenas estavam aderidas à superfície dos cristais deste biomaterial formando uma rede tridimensional onde se notou a capacidade de apreensão de células por esta trama fibrilar (Figura 21).

Qualitativamente a avaliação realizada no $21^{\circ}$ dia na interface da biocerâmica com o tecido ósseo neoformado demonstrou boa capacidade de osteointegração da mesma, ou seja, uma íntima união que pode ser confirmada pela ausência de tecido mole entre estes constituintes teciduais em aumentos que variaram de 500 a 7500 vezes (Figura 22 e 23). No maior aumento é possível observar o embricamento 
micromecânico da estrutura cristalina do biomaterial em questão com o tecido ósseo reparacional (Figura 23B).

No período de 42 dias, observa-se uma maior maturidade e compactação do tecido ósseo neoformado se espalhando por entre as partículas do biomaterial implantado (Figura 24). A interface entre a biocerâmica e osso reparacional não apresentou espaços preenchidos por tecido mole, nem aglomerados de células inflamatórias, mas sim uma intensa ligação micromecânica da matriz orgânica/inorgânica do osso com os cristais cerâmicos (Figura 25). Adequada osteointegração deste material pode ser observado nos dois períodos reparacionais avaliados.

A figura 26 demonstra uma área da biocerâmica em que pode ser evidenciado de um lado do biomaterial a união com o tecido ósseo neoformado e do outro um "gap", provavelmente um artefato produzido pela técnica empregada. Qualitativamente, podemos notar na área em que a união foi rompida uma superfície sem a presença de tecido conjuntivo interposto entre a biocerâmica e a trabécula óssea, sinalizando que estes tecidos estavam em íntima união. 

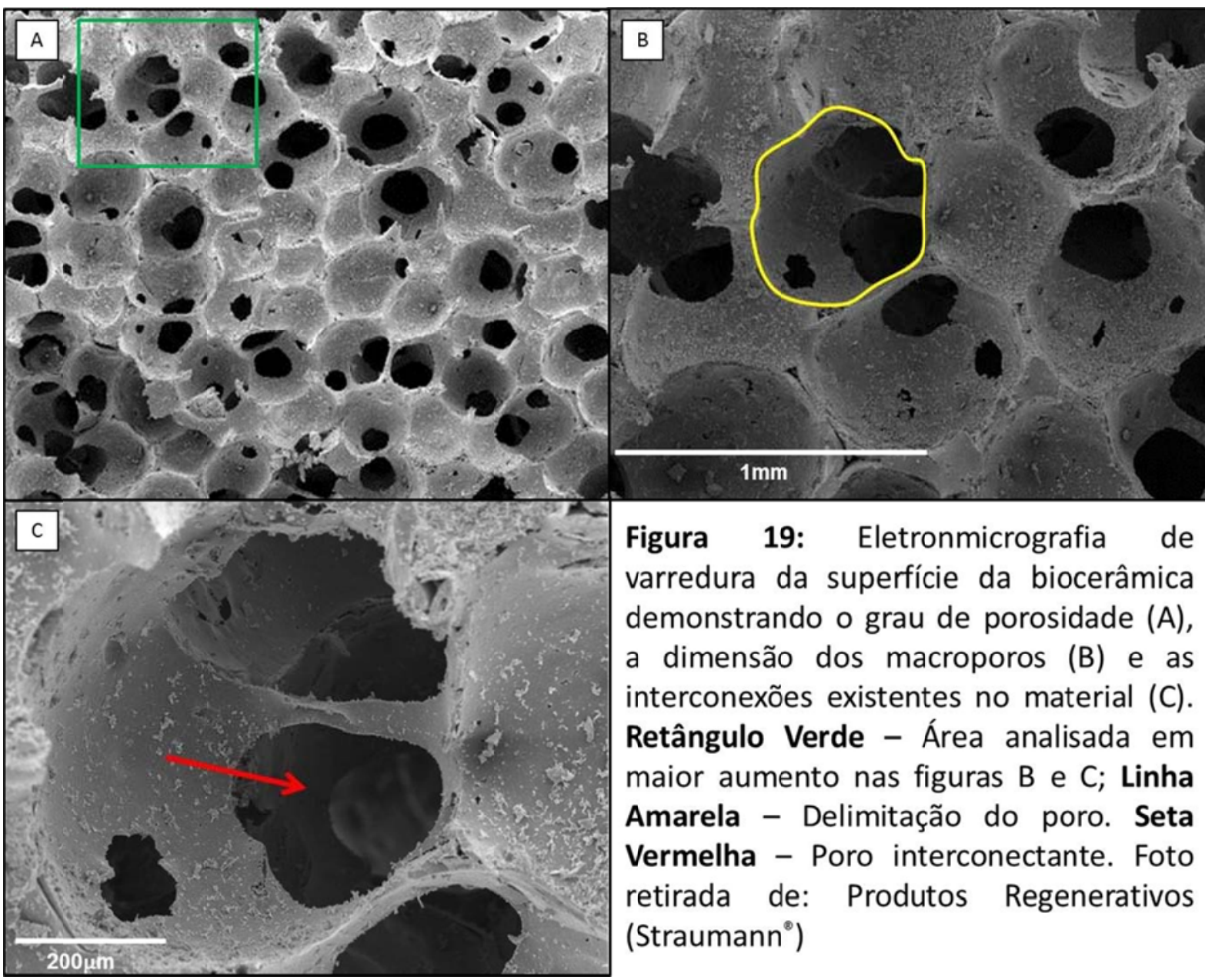

Figura 19: Eletronmicrografia de varredura da superfície da biocerâmica demonstrando o grau de porosidade $(A)$, a dimensão dos macroporos (B) e as interconexões existentes no material (C). Retângulo Verde - Área analisada em maior aumento nas figuras B e C; Linha Amarela - Delimitação do poro. Seta Vermelha - Poro interconectante. Foto retirada de: Produtos Regenerativos (Straumann ${ }^{\circ}$ ) 

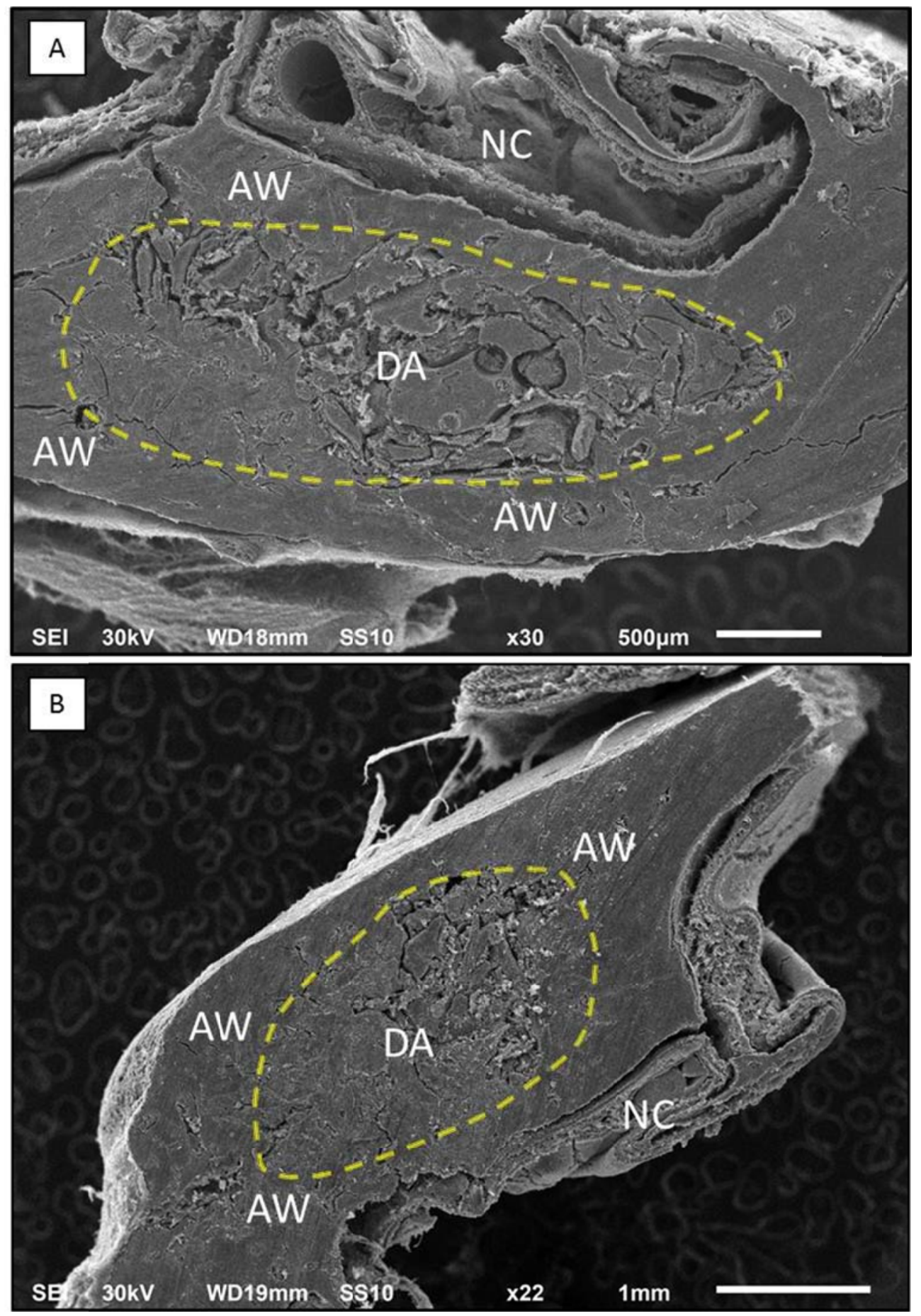

Figura 20: Eletronmicrografias de varredura de cortes transversais de alvéolos dentários onde a biocerâmica foi implantada, aos 21 e 42 dias após a extração do dente. DA - Alvéolo dentário; AW - Paredes do alvéolo dentário; NC - Cavidade Nasal; Pontilhado Amarelo - Delimitação do alvéolo dentário. Observar nítido aumento da área de deposição de osso reparacional compacto no $42^{\circ}$ dia (B), quando comparado aos animais sacrificados no $21^{\circ}$ dia (A). Aumentos ao microscópio: Em A - 30X; Em B - 22X. 

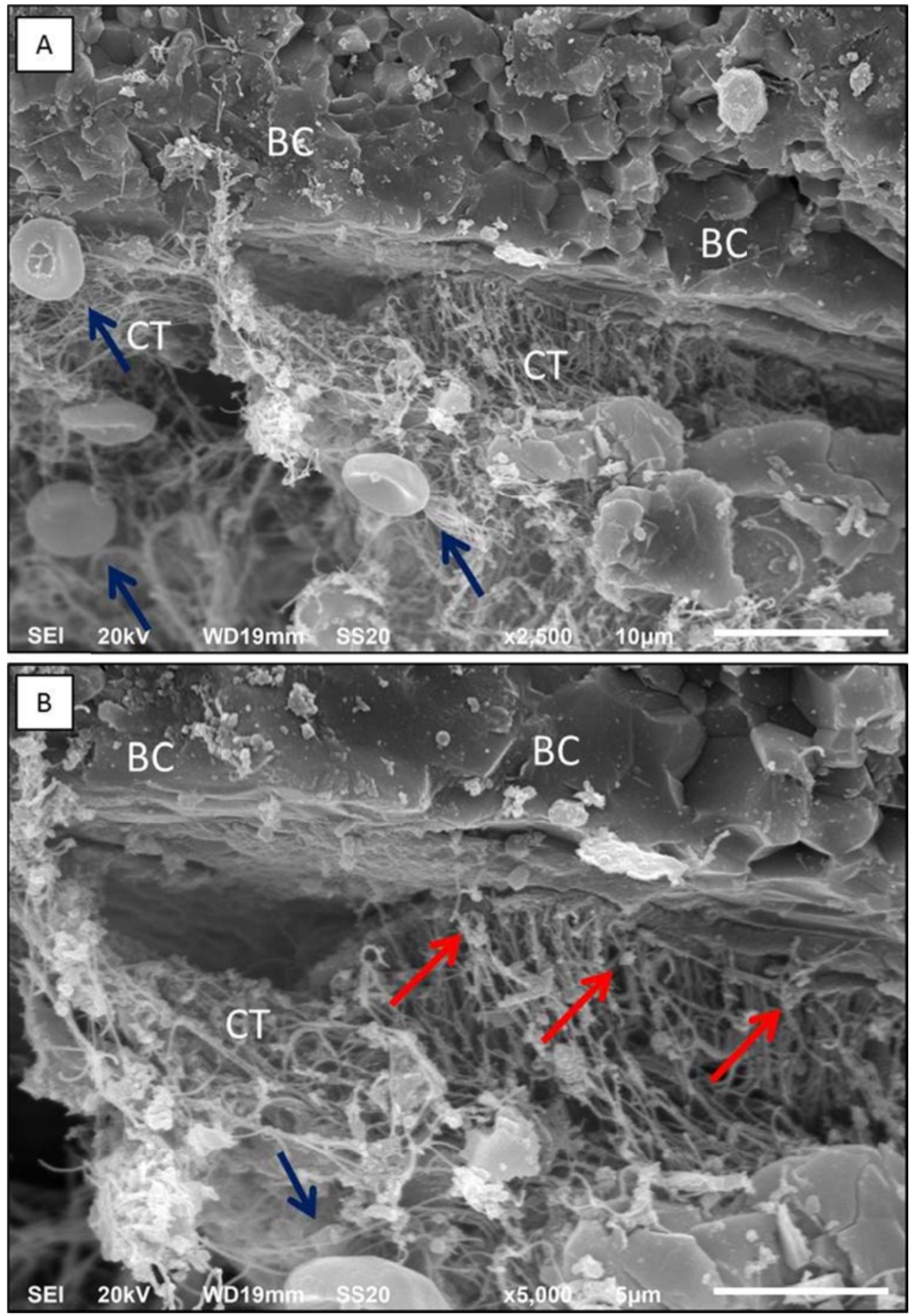

Figura 21: Eletronmicrografias de varredura de cortes transversais de alvéolos dentários onde a biocerâmica foi implantada, aos 21 dias após a extração do dente. Notar na interface entre a biocerâmica e o tecido conjuntivo a presença de hemácias (Setas Azuis), e o tecido conjuntivo aderido à superfície da biocerâmica (Setas Vermelhas). BC- Biocerâmica; CT- Tecido conjuntivo. Aumentos ao microscópio: em A - 2500 X; em B - 5000 X. 

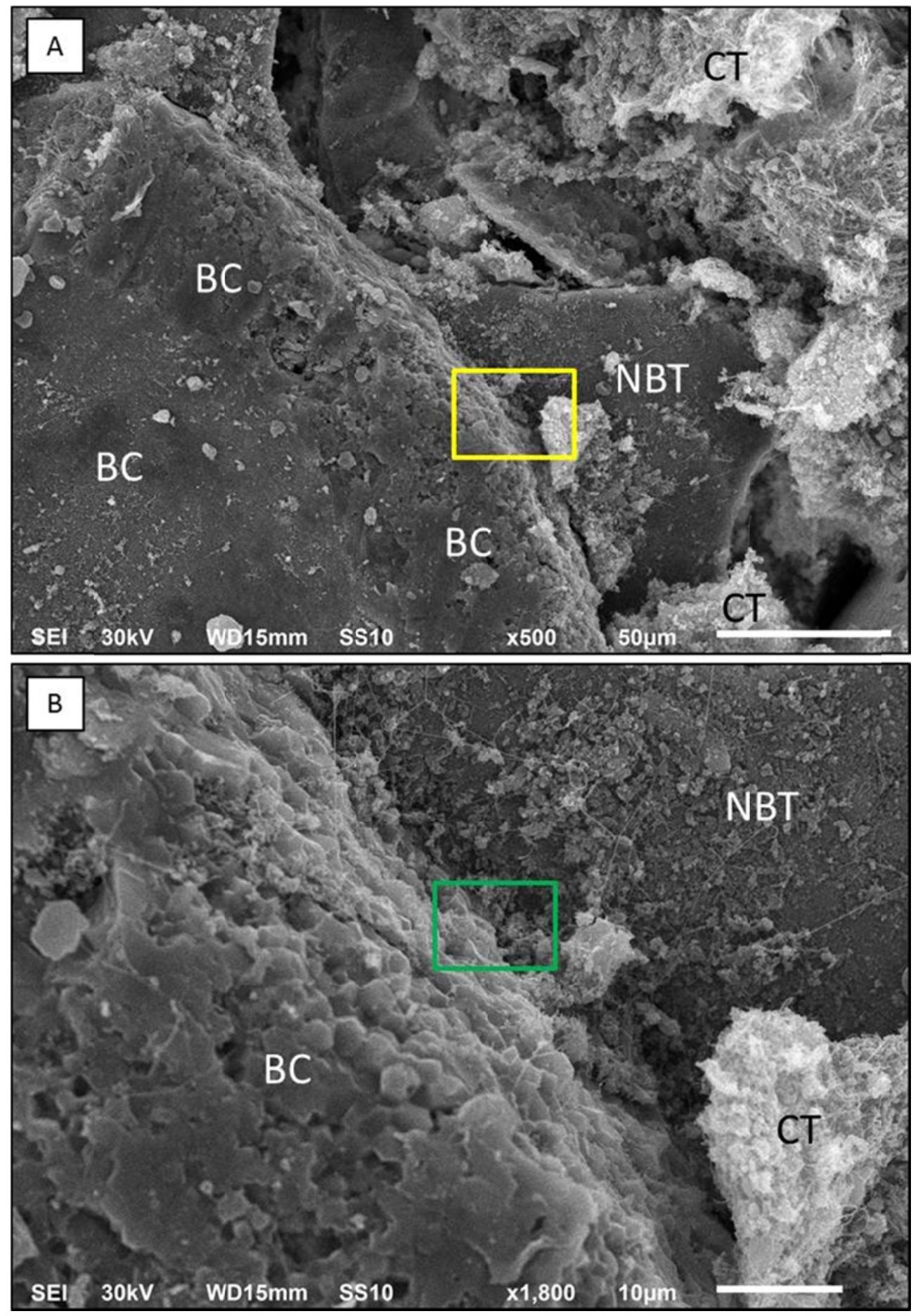

Figura 22: Eletronmicrografias de varredura de cortes transversais de alvéolos dentários onde a biocerâmica foi implantada, aos 21 dias após a extração do dente. Notar neoformação óssea na interface entre a biocerâmica e o tecido ósseo. BCBiocerâmica; NBT- Tecido ósseo neoformado; CT- Tecido conjuntivo; Retângulo Amarelo - Área utilizada para a ampliação obtida na figura B; Retângulo Verde Área utilizada para a ampliação obtida na figura 23A. Aumentos ao microscópio: em A - 500 X; em B - 1800 X. 

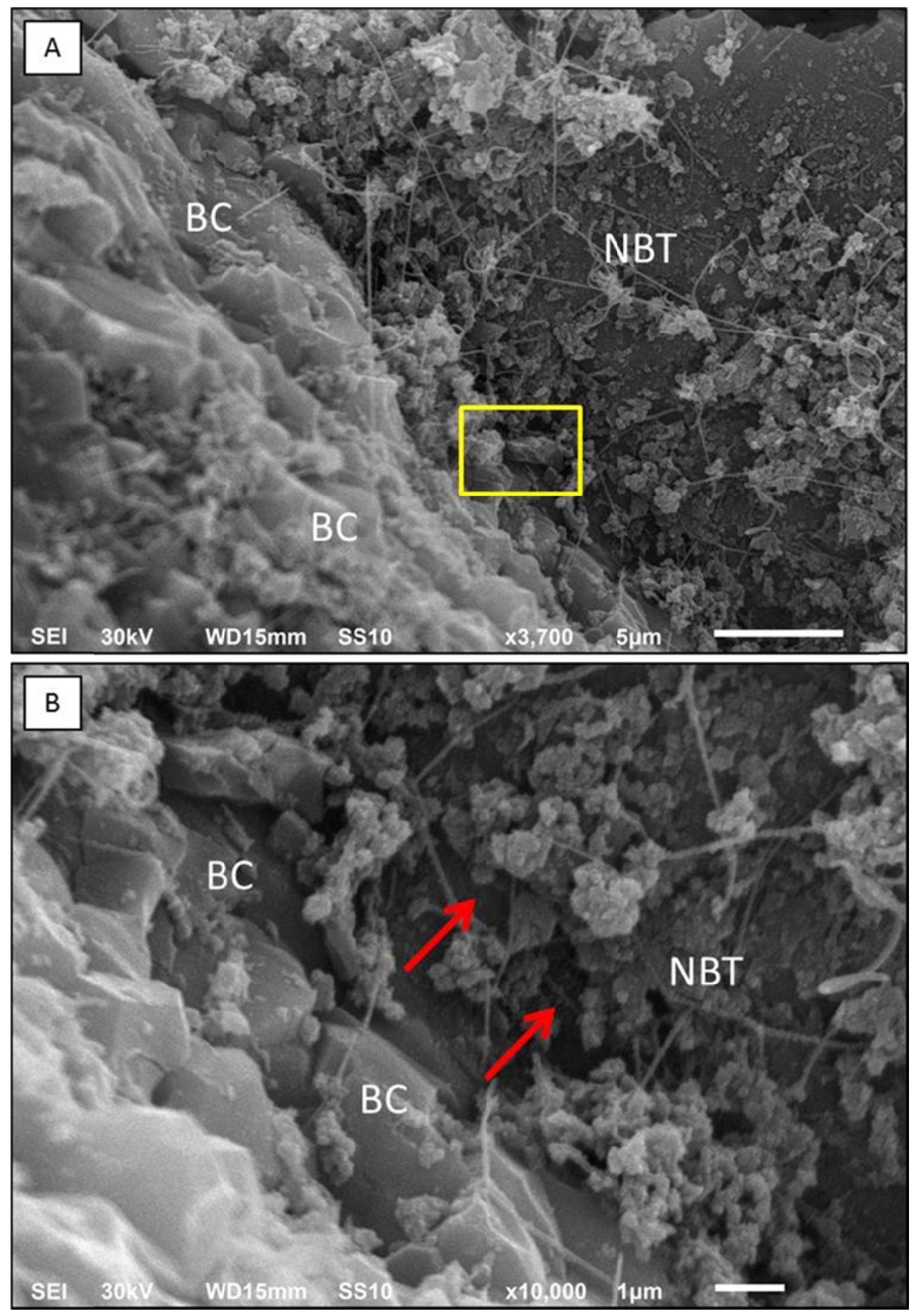

Figura 23: Eletronmicrografias de varredura de cortes transversais de alvéolos dentários onde a biocerâmica foi implantada, aos 21 dias após a extração do dente. Notar a união entre os cristais da biocerâmica e o tecido ósseo (setas vermelhas) na interface entre a biocerâmica e o tecido ósseo neoformado. BC- Biocerâmica; NBTTecido ósseo neoformado; Retângulo Amarelo - Área utilizada para a ampliação obtida na figura B. Aumentos ao microscópio: em A - 3700 X; em B - 10000 X. 

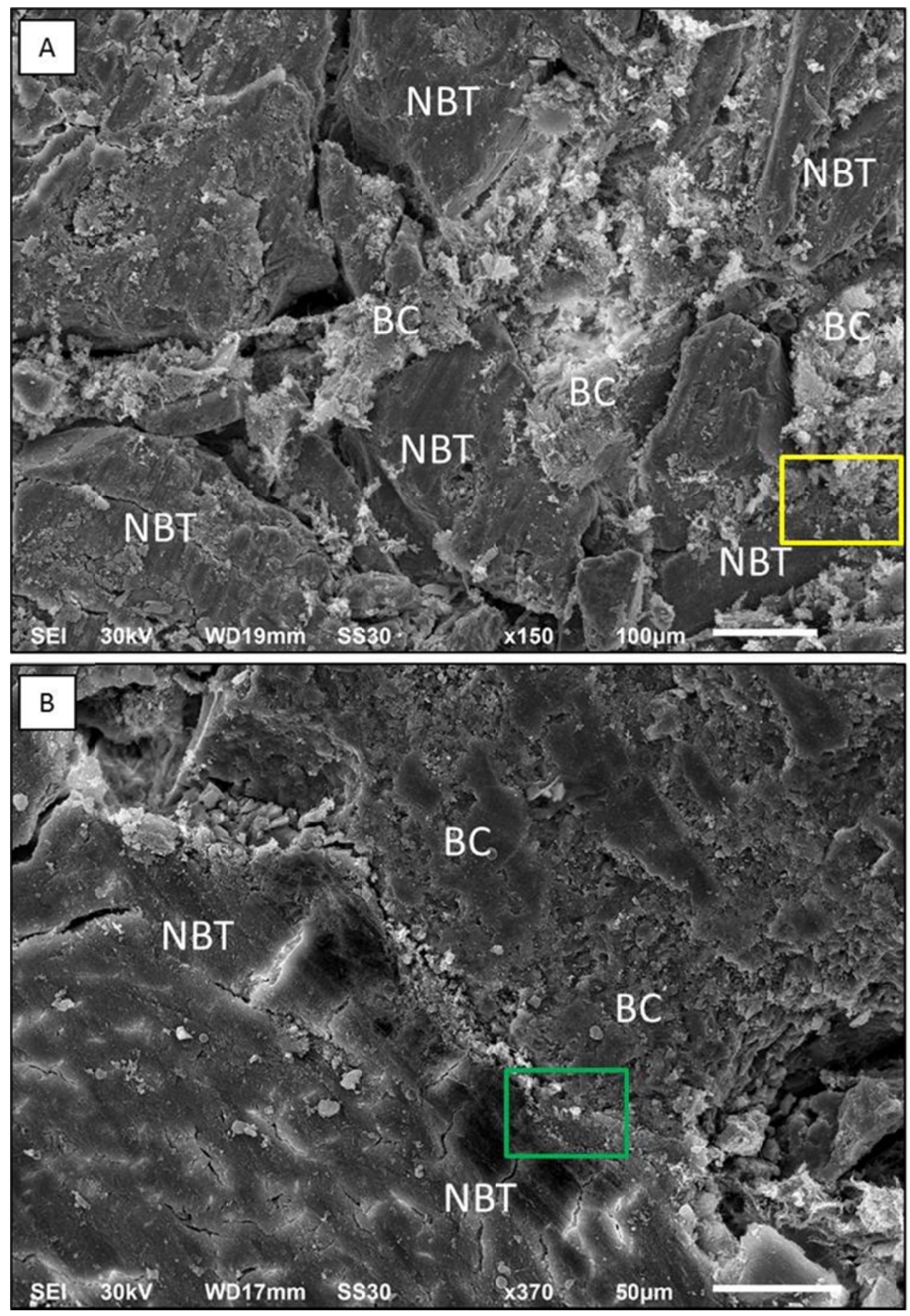

Figura 24: Eletronmicrografias de varredura da interface entre a biocerâmica e o tecido ósseo neoformado em cortes transversais de alvéolos dentários onde a biocerâmica foi implantada, aos 42 dias após a extração do dente. BC- Biocerâmica; NBT- Tecido ósseo neoformado; Retângulo Amarelo - Área utilizada para a ampliação obtida na figura B; Retângulo Verde - Área utilizadla para a ampliação obtida na figura 25A. Aumentos ao microscópio: em A - 150 X; em B - 370 X. 

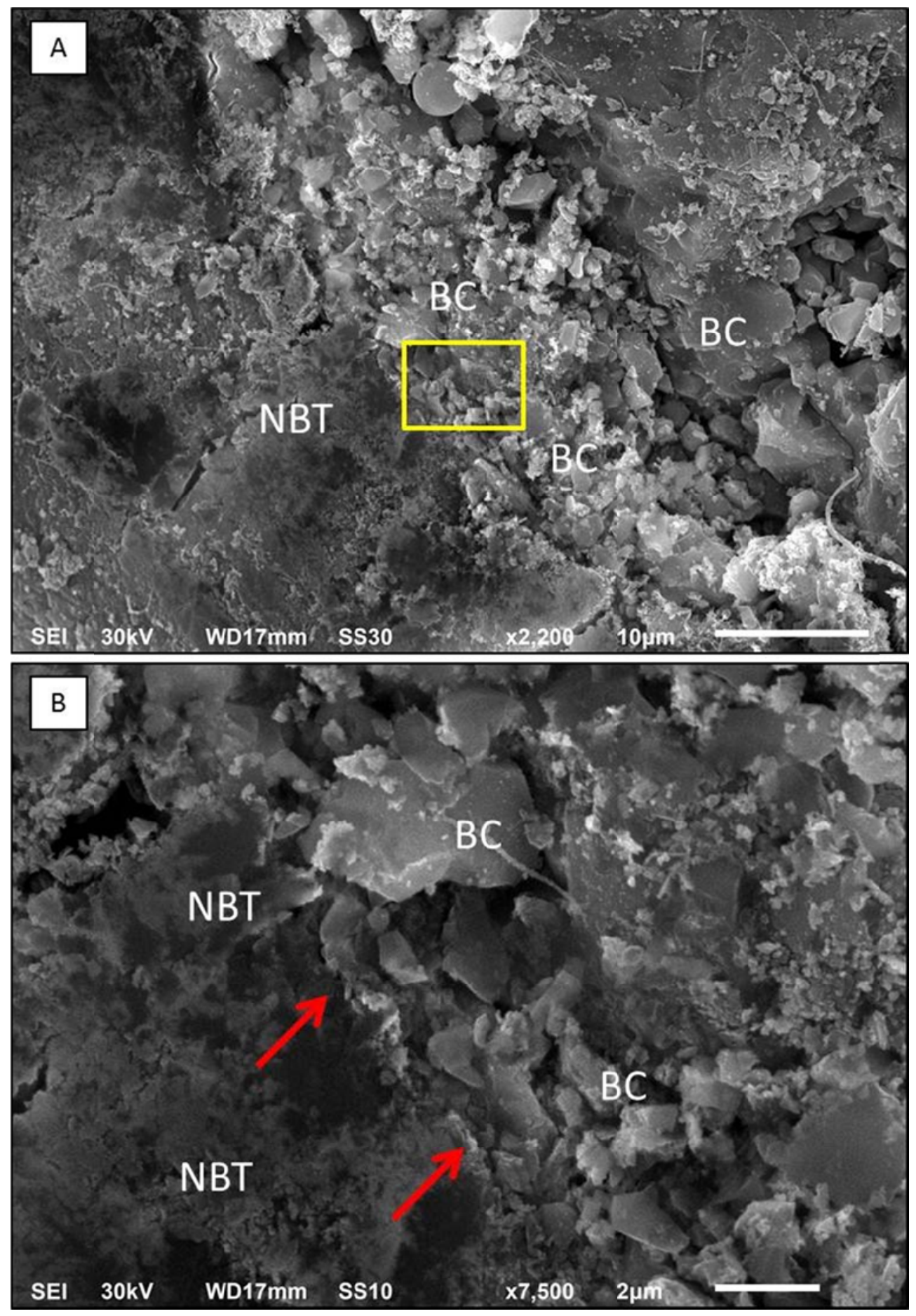

Figura 25: Eletronmicrografias de varredura de cortes transversais de alvéolos dentários onde a biocerâmica foi implantada, aos 42 dias após a extração do dente. Notar a união entre os cristais da biocerâmica e o tecido ósseo (setas vermelhas) na interface entre a biocerâmica e o tecido ósseo neoformado. BC- Biocerâmica; NBTTecido ósseo neoformado; Retângulo Amarelo - Área utilizada para a ampliação obtida na figura B. Aumentos ao microscópio: em A - 2200 X; em B - 7500 X. 


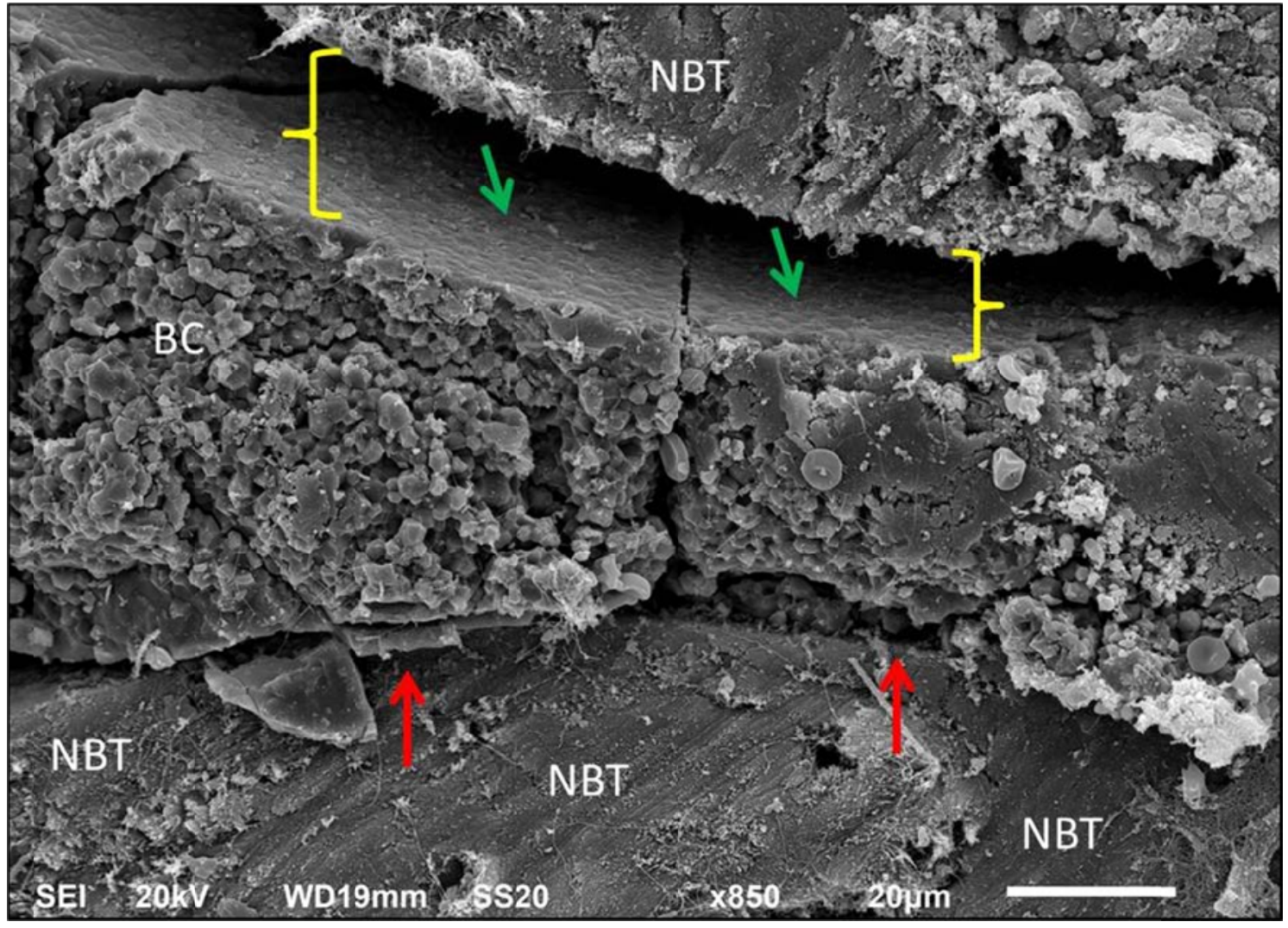

Figura 26: Eletronmicrografias de varredura de interfaces entre a biocerâmica e tecidos ósseos neoformados, em cortes transversais de alvéolos dentários onde a biocerâmica foi implantada, aos 42 dias após a extração do dente. Notar na interface inferior a união entre estes elementos (setas vermelhas) e na superior um descolamento (artefato) produzido pela técnica de preparo do material utilizada (setas verdes). BC- Biocerâmica; NBT- Tecido ósseo neoformado; Chaves Amarelas - Gap entre a biocerâmica e o tecido ósseo neoformado. Aumento ao microscópio: $850 \mathrm{X}$. 


\subsection{RESULTADOS HISTOMÉTRICOS}

\subsubsection{Tecido Ósseo}

Na tabela 1 e na figura 27 são expressos os valores médios e desvio padrão da média do volume percentual de tecido ósseo (tecido ósseo neoformado + biocerâmica) dos grupos controle, osso autógeno, células osteoblásticas, osso autógeno + células osteoblásticas, biocerâmica, biocerâmica + osso autógeno, biocerâmica + células osteoblásticas, e biocerâmica + células osteoblásticas + osso autógeno, 7 dias após a extração dentária. Pode-se observar um maior volume de tecido ósseo quando comparado ao controle (significante a 1\%) nos grupos onde a biocerâmica foi implantada $(\mathrm{BC}$; $\mathrm{BC}+\mathrm{OA} ; \mathrm{BC}+\mathrm{CO}$; $\mathrm{BC}+\mathrm{CO}+\mathrm{OA})$ e onde as células osteoblásticas foram utilizadas isoladamente (grupo CO) (significante a 5\%). Uma maior porcentagem de preenchimento ósseo intra-alveolar, da ordem de $52,4 \%$, foi encontrada quando as células osteoblásticas foram inseridas nas porosidades da biocerâmica e associadas ao osso autógeno da calota craniana (Grupo $\mathrm{BC}+\mathrm{CO}+\mathrm{OA})$

Na tabela 2 e na figura 28 estão expressos os valores médios e desvio padrão da média do volume percentual de tecido ósseo dos grupos controle, osso autógeno, células osteoblásticas, osso autógeno + células osteoblásticas, biocerâmica, biocerâmica + osso autógeno, biocerâmica + células osteoblásticas, e biocerâmica + células osteoblásticas + osso autógeno, 21 dias após a extração dentária. Os dados analisados demonstraram maior porcentagem de tecido ósseo nos grupos $\mathrm{BC}+\mathrm{OA}$ e $\mathrm{BC}+\mathrm{CO}$ (significante a $5 \%$ ), e $\mathrm{BC}+\mathrm{CO}+\mathrm{OA}$ (significante a 1\%) quando comparados aos animais controle. Ainda neste período de 21 dias, o maior 
valor histométrico absoluto do volume ósseo $(67,13 \%)$ foi encontrado no grupo submetido à implantação da biocerâmica, células osteoblásticas e osso autógeno.

Na tabela 3 e na figura 29 são expressos os valores médios e desvio padrão da média do volume percentual de tecido ósseo dos grupos controle, osso autógeno, células osteoblásticas, osso autógeno + células osteoblásticas, biocerâmica, biocerâmica + osso autógeno, biocerâmica + células osteoblásticas, e biocerâmica + células osteoblásticas + osso autógeno, 42 dias após a extração dentária. Os resultados mostraram uma maior porcentagem de tecido ósseo quando comparados aos períodos de 7 e 21 dias, independente do tratamento utilizado. $\mathrm{Na}$ análise feita aos 42 dias, os maiores valores percentuais absolutos de preenchimento ósseo foram encontrados nos grupos $\mathrm{BC}+\mathrm{OA} ; \mathrm{BC}+\mathrm{CO}$ e $\mathrm{BC}+\mathrm{CO}+\mathrm{OA}$ quando comparados aos animais do grupo controle. Diferença estatisticamente significante a $5 \%$ foi observada apenas no último grupo em questão ( $B C+C O+O A)$, os demais tratamentos de enxertia óssea realizados no alvéolo dentário não obtiveram valores significantes em relação ao grupo controle.

A análise estatística através de comparações múltiplas entre os grupos estudados nos períodos de 7, 21 e 42 dias, quanto à porcentagem volumétrica de tecido ósseo intra-alveolar foi realizada através do teste estatístico ANOVA e Tukey, levando em consideração níveis de significância de 1\% e 5\% (Tabela 4). 
Tabela 1: Média aritmética e desvio padrão da média referente ao volume percentual de tecido ósseo dos grupos: controle, osso autógeno (OA), células osteoblásticas ( $\mathrm{CO})$, osso autógeno + células osteoblásticas (OA+CO), biocerâmica $(\mathrm{BC})$, biocerâmica + osso autógeno $(\mathrm{BC}+\mathrm{OA})$, biocerâmica + células osteoblásticas $(\mathrm{BC}+\mathrm{CO})$, e biocerâmica + células osteoblásticas + osso autógeno $(\mathrm{BC}+\mathrm{CO}+\mathrm{OA}) 7$ dias após a extração dentária. Teste estatístico ANOVA e Tukey. (n=5).

** significante a $1 \%$. * significante a $5 \%$.

\begin{tabular}{|c|c|c|c|c|c|c|c|}
\hline \multicolumn{7}{|c|}{ Tecido Ósseo - 7 dias } \\
\hline Controle & OA & Co & OA+CO & BC & BC+OA & BC+CO & BC+CO+OA \\
\hline 33,7 & 35,9 & 38,0 & 32,9 & 42,7 & 48,4 & 47,8 & 52,4 \\
\pm & \pm & \pm & \pm & \pm & \pm & \pm & \pm \\
1,29 & 1,39 & $1,04^{*}$ & 2,07 & $1,84^{\star *}$ & $2,26^{\star *}$ & $2,04^{\star *}$ & $2,3^{\star *}$ \\
\hline
\end{tabular}

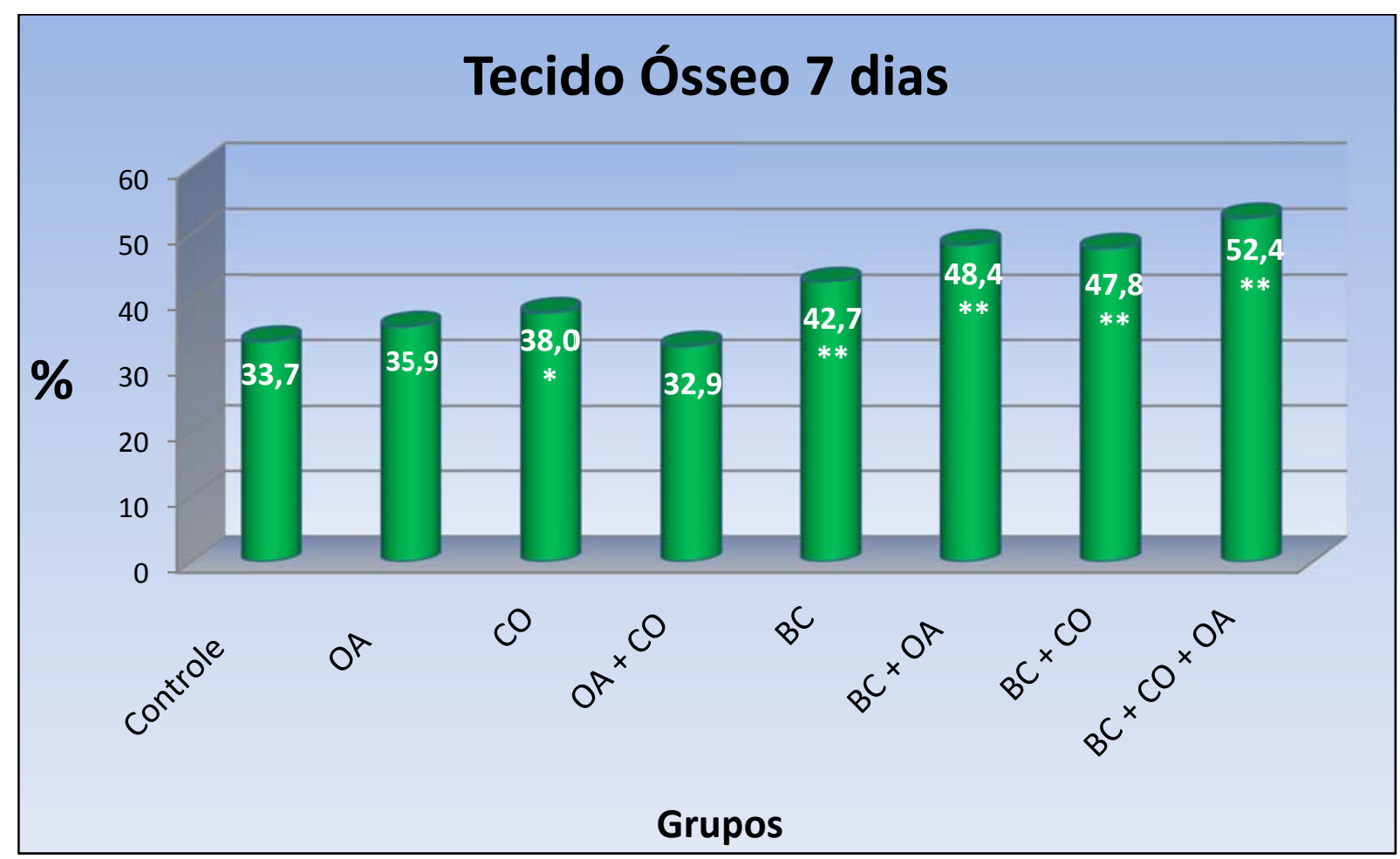

Figura 27: Média aritmética da fração de volume (\%) de tecido ósseo no alvéolo dentário dos animais controle, osso autógeno (OA), células osteoblásticas (CO), osso autógeno + células osteoblásticas $(\mathrm{OA}+\mathrm{CO})$, biocerâmica $(\mathrm{BC})$, biocerâmica + osso autógeno (BC+OA), biocerâmica + células osteoblásticas ( $\mathrm{BC}+\mathrm{CO})$, e biocerâmica + células osteoblásticas + osso autógeno ( $\mathrm{BC}+\mathrm{CO}+\mathrm{OA}), 7$ dias após a extração dentária. ** significante a 1\%; * significante a 5\%. n=05 
Tabela 2: Média aritmética e desvio padrão da média referente ao volume percentual de tecido ósseo dos grupos: controle, osso autógeno (OA), células osteoblásticas ( $\mathrm{CO})$, osso autógeno + células osteoblásticas $(\mathrm{OA}+\mathrm{CO})$, biocerâmica $(\mathrm{BC})$, biocerâmica + osso autógeno $(\mathrm{BC}+\mathrm{OA})$, biocerâmica + células osteoblásticas $(\mathrm{BC}+\mathrm{CO})$, e biocerâmica + células osteoblásticas + osso autógeno $(\mathrm{BC}+\mathrm{CO}+\mathrm{OA}) \mathbf{2 1}$ dias após a extração dentária. Teste estatístico ANOVA e Tukey. (n=5).

** significante a $1 \%$; * significante a $5 \%$.

\begin{tabular}{|c|c|c|c|c|c|c|c|}
\hline \multicolumn{7}{|c|}{ Tecido Ósseo - 21 dias } \\
\hline Controle & OA & CO & OA+CO & BC & BC+OA & BC+Co & BC+CO+OA \\
\hline 58,4 & 54,4 & 52,3 & 55,3 & 57,4 & 65,6 & 66,6 & 67,1 \\
\pm & \pm & \pm & \pm & \pm & \pm & \pm & \pm \\
1,2 & 1,22 & 2,33 & 1,12 & 2,26 & $2,11^{\star}$ & $2,09 *$ & $2,32^{\star *}$ \\
\hline
\end{tabular}

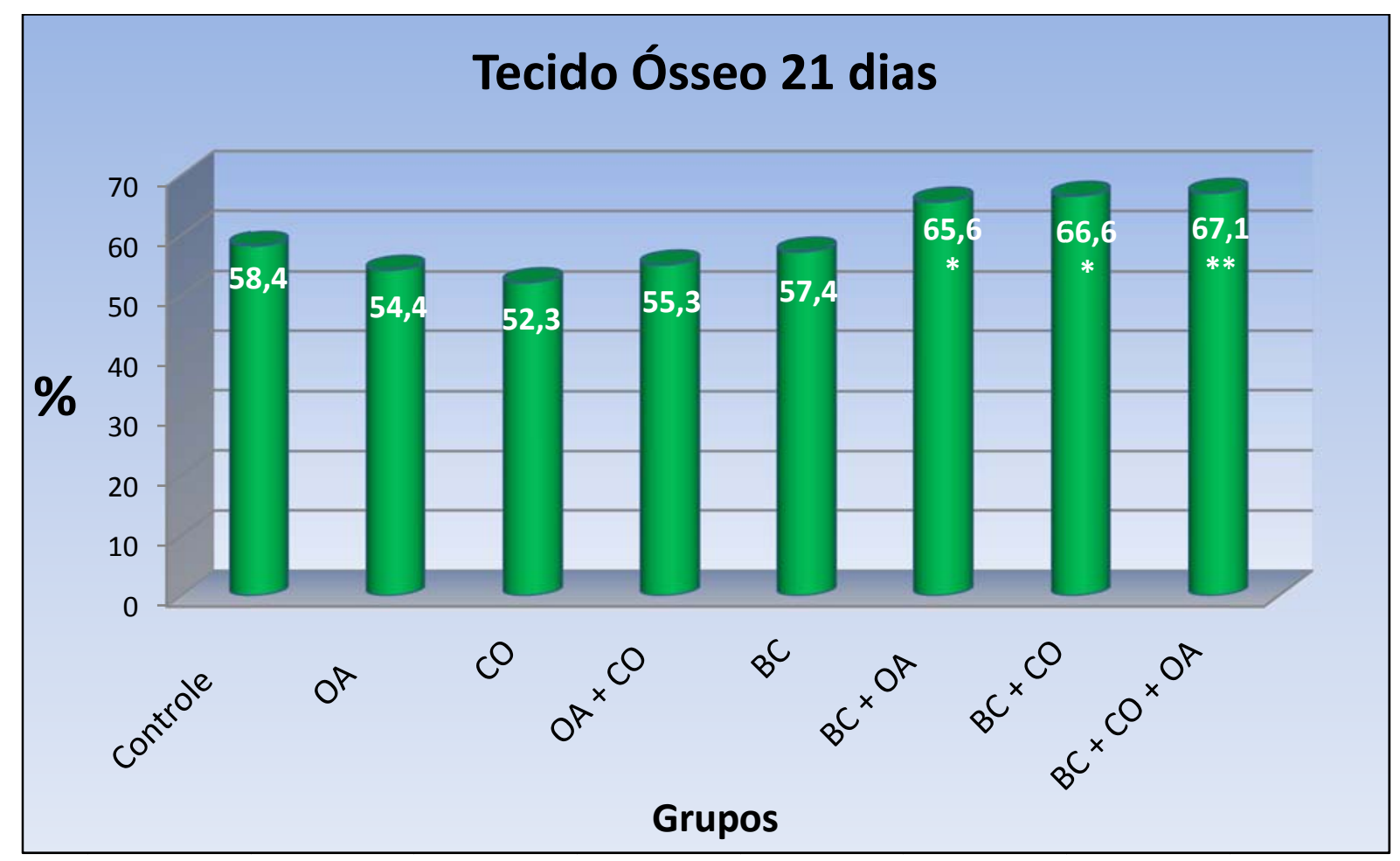

Figura 28: Média aritmética da fração de volume (\%) de tecido ósseo no alvéolo dentário dos animais controle, osso autógeno (OA), células osteoblásticas (CO), osso autógeno + células osteoblásticas $(\mathrm{OA}+\mathrm{CO})$, biocerâmica $(\mathrm{BC})$, biocerâmica + osso autógeno (BC+OA), biocerâmica + células osteoblásticas ( $\mathrm{BC}+\mathrm{CO})$, e biocerâmica + células osteoblásticas + osso autógeno $(B C+C O+O A), 21$ dias após a extração dentária. ** significante a 1\%; * significante a 5\%. n=05. 
Tabela 3: Média aritmética e desvio padrão da média referente ao volume percentual de tecido ósseo dos grupos: controle, osso autógeno (OA), células osteoblásticas ( $\mathrm{CO})$, osso autógeno + células osteoblásticas $(\mathrm{OA}+\mathrm{CO})$, biocerâmica $(\mathrm{BC})$, biocerâmica + osso autógeno $(\mathrm{BC}+\mathrm{OA})$, biocerâmica + células osteoblásticas $(\mathrm{BC}+\mathrm{CO})$ e biocerâmica + células osteoblásticas + osso autógeno (BC+CO+OA) 42 dias após a extração dentária. Teste estatístico ANOVA e Tukey. (n=5).

** significante a $1 \%$; * significante a $5 \%$.

\begin{tabular}{|c|c|c|c|c|c|c|c|}
\hline \multicolumn{7}{|c|}{ Tecido Ósseo - 42 dias } \\
\hline Controle & OA & CO & OA+CO & BC & BC+OA & BC+CO & BC+CO+OA \\
\hline 72,1 & 62,2 & 70,3 & 71,0 & 70,8 & 75,2 & 73,1 & 78,9 \\
\pm & \pm & \pm & \pm & \pm & \pm & \pm & \pm \\
1,73 & 2,01 & 2,84 & 1,37 & 1,8 & 1,59 & 1,81 & $2,76^{\star}$ \\
\hline
\end{tabular}

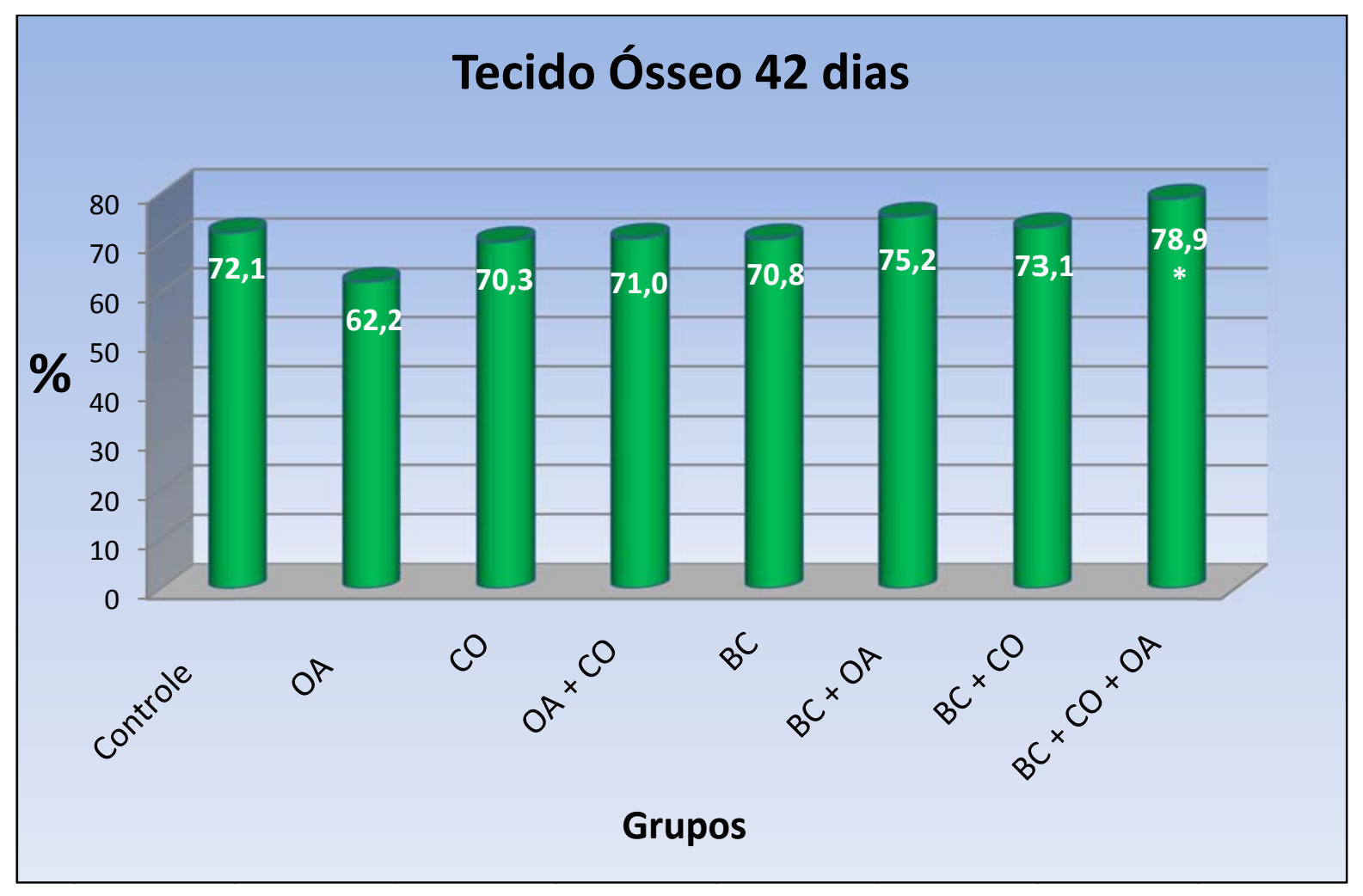

Figura 29: Média aritmética da fração de volume (\%) de tecido ósseo no alvéolo dentário dos animais controle, osso autógeno (OA), células osteoblásticas (CO), osso autógeno + células osteoblásticas $(\mathrm{OA}+\mathrm{CO})$, biocerâmica $(\mathrm{BC})$, biocerâmica + osso autógeno (BC+OA), biocerâmica + células osteoblásticas (BC+CO), e biocerâmica + células osteoblásticas + osso autógeno $(\mathrm{BC}+\mathrm{CO}+\mathrm{OA}), \mathbf{4 2}$ dias após a extração dentária. ** significante a 1\%; * significante a 5\%. n=05. 
Tabela 4: Comparações múltiplas entre os diversos grupos estudados através do teste estatístico ANOVA e Tukey para a porcentagem de tecido ósseo em 7, 21 e 42 dias (significância descrita na tabela). C - controle; OA - osso autógeno; CO células osteoblásticas; BC - biocerâmica.

\section{Tecido Ósseo}

\begin{tabular}{|c|c|c|c|}
\hline Grupos & 7 dias & 21 dias & 42 dias \\
\hline $\mathrm{C} \times \mathrm{OA}$ & n.s. & n.s. & $1 \%$ \\
\hline $\mathrm{C} \times \mathrm{CO}$ & $5 \%$ & n.s. & n.s. \\
\hline $\mathrm{C} \times \mathrm{OACO}$ & n.s. & n.s. & n.s. \\
\hline $\mathrm{C} \times \mathrm{BC}$ & $1 \%$ & n.s. & n.s. \\
\hline $\mathrm{C} \times \mathrm{BCOA}$ & $1 \%$ & $5 \%$ & n.s. \\
\hline $\mathrm{C} \times \mathrm{BCCO}$ & $1 \%$ & $5 \%$ & n.s. \\
\hline $\mathrm{C} \times \mathrm{BCCOOA}$ & $1 \%$ & $5 \%$ & $5 \%$ \\
\hline $\mathrm{OA}$ x CO & n.s. & n.s. & $5 \%$ \\
\hline OA $\times$ OACO & n.s. & n.s. & $5 \%$ \\
\hline $\mathrm{OA} \times \mathrm{BC}$ & $5 \%$ & n.s. & $5 \%$ \\
\hline $\mathrm{OA} \times \mathrm{BCOA}$ & $1 \%$ & $1 \%$ & $1 \%$ \\
\hline $\mathrm{OA} \times \mathrm{BCCO}$ & $1 \%$ & $1 \%$ & $1 \%$ \\
\hline OA $\times$ BCCOOA & $1 \%$ & $1 \%$ & $1 \%$ \\
\hline CO x OACO & $5 \%$ & n.s. & n.s. \\
\hline $\mathrm{CO} \times \mathrm{BC}$ & n.s. & n.s. & n.s. \\
\hline $\mathrm{CO} \times \mathrm{BCOA}$ & $5 \%$ & $1 \%$ & $5 \%$ \\
\hline $\mathrm{CO} \times \mathrm{BCCO}$ & $5 \%$ & $1 \%$ & n.s. \\
\hline $\mathrm{CO} \times \mathrm{BCCOOA}$ & $1 \%$ & $1 \%$ & $1 \%$ \\
\hline OACO x BC & $1 \%$ & n.s. & n.s. \\
\hline OACO x BCOA & $1 \%$ & $5 \%$ & $5 \%$ \\
\hline $\mathrm{OACO} \times \mathrm{BCCO}$ & $1 \%$ & $1 \%$ & n.s. \\
\hline OACO x BCCOOA & $1 \%$ & $1 \%$ & $1 \%$ \\
\hline $\mathrm{BC} \times \mathrm{BCOA}$ & $5 \%$ & $5 \%$ & $5 \%$ \\
\hline $\mathrm{BC} \times \mathrm{BCCO}$ & $5 \%$ & $5 \%$ & n.s. \\
\hline $\mathrm{BC} \times \mathrm{BCCOOA}$ & $1 \%$ & $5 \%$ & $1 \%$ \\
\hline BCOA x BCCO & n.s. & n.s. & n.s. \\
\hline BCOA x BCCOOA & n.s. & n.s. & n.s. \\
\hline BCCO $\times$ BCCOOA & n.s. & n.s. & $5 \%$ \\
\hline
\end{tabular}

$\underline{\text { n.S. - não significante }}$ 


\subsubsection{Biocerâmica}

As tabelas 5, 6, 7 e 8, e as figuras 30, 31, 32 e 33 demonstram os percentuais volumétricos de tecido ósseo neoformado (osso vital), tecido mole (tecido conjuntivo + coágulo sanguíneo) e biocerâmica no terço médio do alvéolo dentário no $7^{\circ}, 21^{\circ} \mathrm{e}$ $42^{\circ}$ dia pós-extração dentária dos grupos biocerâmica (BC), biocerâmica + osso autógeno $(\mathrm{BC}+\mathrm{OA})$, biocerâmica + células osteoblásticas $(\mathrm{BC}+\mathrm{CO})$ e biocerâmica + células osteoblásticas + osso autógeno $(\mathrm{BC}+\mathrm{CO}+\mathrm{OA})$. A análise qualitativa do alvéolo dentário em menor aumento demonstrou que grande parte dos biomateriais, incluindo a biocerâmica, estavam mais concentrados no terço médio alveolar dos animais. Para os quatro grupos em questão, observam-se aos 7 dias valores percentuais de biocerâmica similares entre si (sem diferenças estatisticamente significantes) evidenciando uma padronização da quantidade do material de enxertia cerâmico implantado no alvéolo durante a cirurgia (Tabela 10 e figura 35). Paralelamente a redução na porcentagem da biocerâmica implantada, bem como do tecido mole (tecido conjuntivo + coágulo) pode ser observado, com o decorrer do processo de reparação do alvéolo dentário, à deposição de novo tecido ósseo vital em todos estes grupos. A análise do grau de reabsorção do material cerâmico de 7 até 42 dias, demonstrou uma queda dos valores percentuais (significante a 1\%) para todos os grupos avaliados (Tabela 10 e figura 35).

As tabelas 9, 10 e 11, e as figuras 34,35 e 36 mostram uma análise comparativa entre os grupos em questão quanto à formação do novo tecido ósseo (tecido ósseo vital) bem como a reabsorção da biocerâmica e do tecido mole nos períodos de 7, 21 e 42 dias pós-extração dentária. Os dados da tabela 9 e da figura 34 demonstram que no $7^{\circ}$ dia houve uma maior deposição de tecido ósseo (significante a 1\%) no grupo com a implantação da biocerâmica + células 
osteoblásticas + osso autógeno (BC+CO+OA), e significante a 5\% quando do uso da biocerâmica e osso autógeno associados (BC+OA) em comparação aos animais que receberam apenas a biocerâmica $(\mathrm{BC})$ como material de enxerto. No $21^{\circ}$ dia, todos os grupos onde a biocerâmica foi associada ( $B C+O A, B C+C O$ e $B C+C O+O A)$ obtiveram valores percentuais maiores em relação ao grupo BC (significante a 1\%). Aos 42 dias, a análise histométrica também revelou as maiores porcentagens, significantes a 1\%, de tecido ósseo vital para os grupos $\mathrm{BC}+\mathrm{OA}, \mathrm{BC}+\mathrm{CO}$ e $\mathrm{BC}+\mathrm{CO}+\mathrm{OA}$ em comparação aos animais que receberam a biocerâmica isoladamente $(\mathrm{BC})$. O maior volume no terço médio intra-alveolar de tecido ósseo neoformado $(53,2 \%)$, ao final do período reparacional, foi observado quando as células osteoblásticas foram carreadas pela biocerâmica e associadas ao osso autógeno da calota craniana (grupo $\mathrm{BC}+\mathrm{CO}+\mathrm{OA})$.

A tabela 12 e a figura 37 demonstram a relação osso vital/biocerâmica entre os diversos grupos que receberam a implantação da biocerâmica isoladamente ou em associação ao osso autógeno, células osteoblásticas ou ambos, nos períodos de 7, 21 e 42 dias. A atividade osteogênica aos 7 dias foi menor para o grupo implantado com a biocerâmica (grupo BC), demonstrado pela linha azul (índice de 0,35), seguido pelo grupo $\mathrm{BC}+\mathrm{CO}$ com um índice de 0,41 (Linha verde). Em terceiro, com um valor de 0,50 o grupo BC+OA (Linha vermelha), e por último com a associação das células carreadas pela biocerâmica conjuntamente com as partículas do osso autógeno $(B C+C O+O A)$, o de maior poder osteogênico $(0,61)$, evidenciado pela linha roxa. Aos 21 dias, o grupo BC revelou menor poder osteogênico $(0,66)$, seguido por valores semelhantes dos grupos $B C+C O(0,88)$, $B C+C O+O A(0,89)$ e $B C+O A(0,93)$. Aos 42 dias, o grupo BC ainda é o de menor osteogenicidade $(1,16)$, seguido pelo grupo $\mathrm{BC}+\mathrm{OA}(1,22)$, em terceiro com um 
índice de 1,44 vem o grupo $\mathrm{BC}+\mathrm{CO}$, e com melhor resultado na síntese de tecido ósseo em relação à quantidade de biocerâmica, com um índice de 1,50 o grupo $\mathrm{BC}+\mathrm{CO}+\mathrm{OA}$.

A análise estatística através de comparações múltiplas entre os grupos estudados ( $\mathrm{BC}, \mathrm{BC}+\mathrm{OA}, \mathrm{BC}+\mathrm{CO}$ e $\mathrm{BC}+\mathrm{CO}+\mathrm{OA})$ e entre os períodos em questão (7, 21 e 42 dias) quanto à porcentagem volumétrica de tecido ósseo vital, biocerâmica e tecido mole intra-alveolar foi realizada através do teste estatístico ANOVA e Tukey, levando em consideração níveis de significância de 1\% e 5\% (Tabelas 13, 14, 15 e 16). 
Tabela 5: Média aritmética e desvio padrão da média referente ao volume percentual de tecido ósseo vital, biocerâmica e tecido mole (tecido conjuntivo + coágulo sanguíneo) no terço médio alveolar do grupo com implantação de biocerâmica (BC) aos 7, 21 e 42 dias após a extração dentária. Teste estatístico ANOVA e Tukey. $(n=5)$. ** significante a $1 \%$.

\begin{tabular}{|c|c|c|c|}
\hline \multicolumn{4}{|c|}{ Grupo BC } \\
\hline & $\mathbf{7}$ dias & 21 dias & 42 dias \\
\hline Tecido Mole & $38,28 \pm 2,3$ & $29,3 \pm 2,3^{\star \star}$ & $22,45 \pm 1,45^{\star \star}$ \\
\hline Biomaterial & $45,6 \pm 1,37$ & $42,35 \pm 3,1$ & $35,8 \pm 2,88^{\star \star}$ \\
\hline Osso Vital & $16,11 \pm 1,2$ & $28,35 \pm 2,2^{\star \star}$ & $41,75 \pm 2,16^{\star \star}$ \\
\hline
\end{tabular}

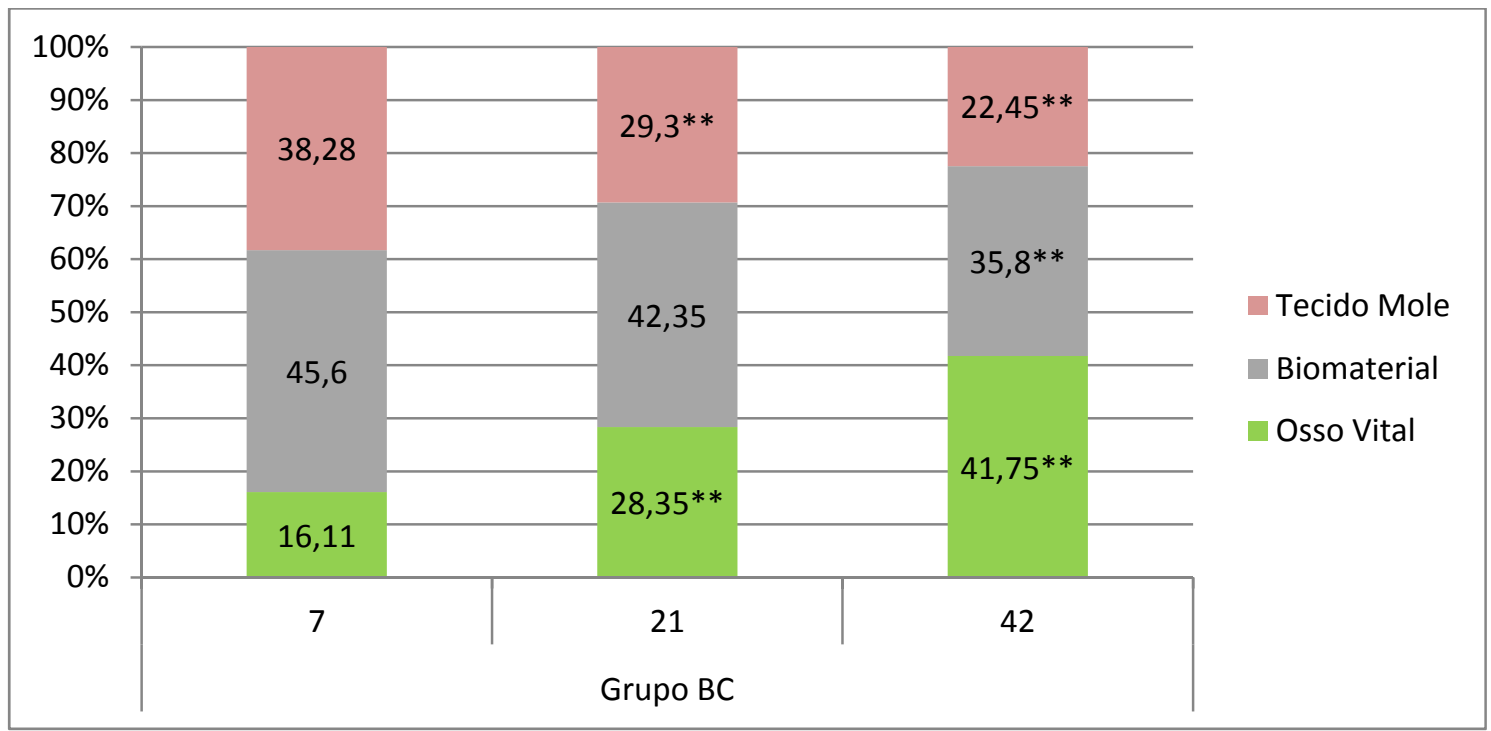

Figura 30: Média aritmética da fração volumétrica (\%) de tecido ósseo vital, biocerâmica e tecido mole (tecido conjuntivo + coágulo sanguíneo) no terço médio alveolar dos animais implantados com a biocerâmica (BC) no $7^{\circ}, 21^{\circ}$ e $42^{\circ}$ dia após a extração dentária. ** significante a $1 \%$. 
Tabela 6: Média aritmética e desvio padrão da média referente ao volume percentual de tecido ósseo vital, biocerâmica e tecido mole (tecido conjuntivo + coágulo sanguíneo) no terço médio alveolar do grupo com implantação de biocerâmica + osso autógeno (BC+OA) aos 7, 21 e 42 dias após a extração dentária. Teste estatístico ANOVA e Tukey. $(n=5)$. ** significante a 1\%. * significante a $5 \%$.

\begin{tabular}{|c|c|c|c|}
\hline \multicolumn{4}{|c|}{ Grupo BC + OA } \\
\hline & $\mathbf{7}$ dias & $\mathbf{2 1}$ dias & 42 dias \\
\hline Tecido Mole & $31,12 \pm 2,11$ & $18,15 \pm 1,88^{\star \star}$ & $11,04 \pm 1,05^{\star \star}$ \\
\hline Biomaterial & $45,64 \pm 2,12$ & $42,25 \pm 2,33$ & $39,92 \pm 2,09^{\star}$ \\
\hline Osso Vital & $23,24 \pm 2,03$ & $39,6 \pm 2,74^{\star \star}$ & $49,04 \pm 2,08^{\star \star}$ \\
\hline
\end{tabular}

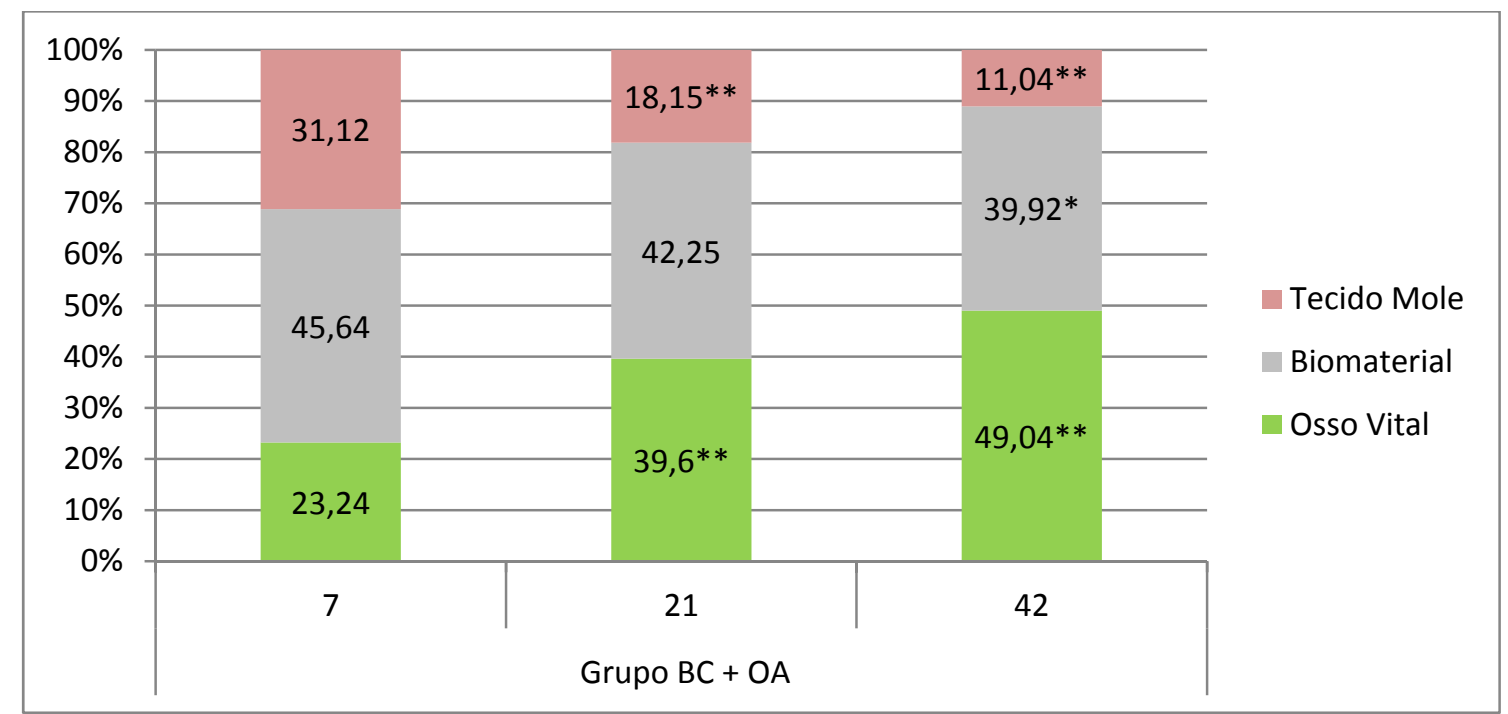

Figura 31: Média aritmética da fração volumétrica (\%) de tecido ósseo vital, biocerâmica e tecido mole (tecido conjuntivo + coágulo sanguíneo) no terço médio alveolar dos animais implantados com a biocerâmica + osso autógeno (BC+OA) no $7^{\circ}, 21^{\circ}$ e $42^{\circ}$ dia após a extração dentária. ** significante a 1\%. * significante a $5 \%$. 
Tabela 7: Média aritmética e desvio padrão da média referente ao volume percentual de tecido ósseo vital, biocerâmica e tecido mole (tecido conjuntivo + coágulo sanguíneo) no terço médio alveolar do grupo com implantação de biocerâmica + células osteoblásticas (BC+CO) aos 7, 21 e 42 dias após a extração dentária. Teste estatístico ANOVA e Tukey. $(n=5) .{ }^{* *}$ significante a $1 \%$.

\begin{tabular}{|c|c|c|c|}
\hline \multicolumn{4}{|c|}{ Grupo BC + CO } \\
\hline & $\mathbf{7}$ dias & $\mathbf{2 1}$ dias & 42 dias \\
\hline Tecido Mole & $36,63 \pm 2,5$ & $18,2 \pm 1,43^{\star \star}$ & $10,68 \pm 1,25^{\star \star}$ \\
\hline Biomaterial & $44,8 \pm 2,11$ & $43,3 \pm 2,61$ & $36,48 \pm 1,07^{\star \star}$ \\
\hline Osso Vital & $18,56 \pm 1,56$ & $38,5 \pm 2,98^{\star \star}$ & $52,8 \pm 1,7^{\star \star}$ \\
\hline
\end{tabular}

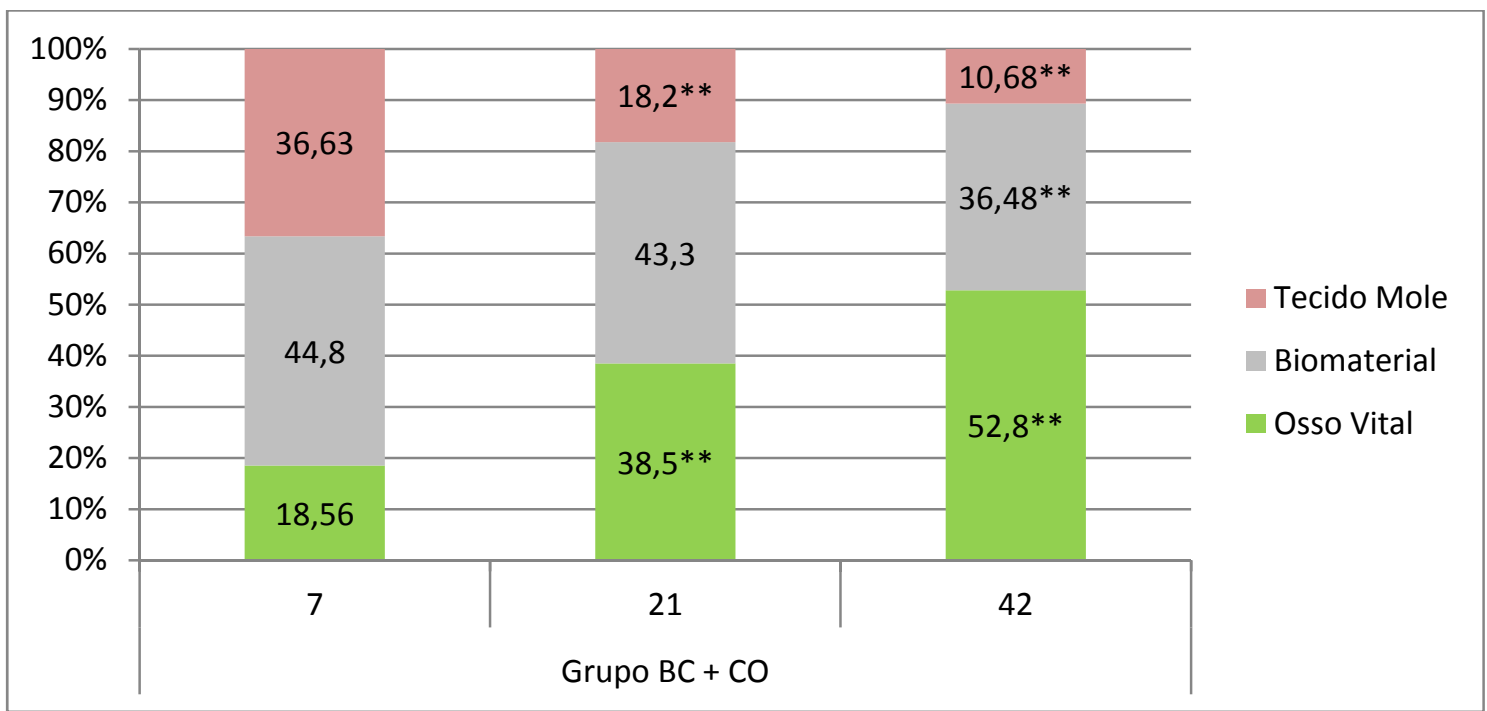

Figura 32: Média aritmética da fração volumétrica (\%) de tecido ósseo vital, biocerâmica e tecido mole (tecido conjuntivo + coágulo sanguíneo) no terço médio alveolar dos animais implantados com a biocerâmica + células osteoblásticas (BC+CO) no $7^{\circ}, 21^{\circ}$ e $42^{\circ}$ dia após a extração dentária. ** significante a $1 \%$. 
Tabela 8: Média aritmética e desvio padrão da média referente ao volume percentual de tecido ósseo vital, biocerâmica e tecido mole (tecido conjuntivo + coágulo sanguíneo) no terço médio alveolar do grupo com implantação de biocerâmica + células osteoblásticas + osso autógeno (BC+CO+OA) aos 7, 21 e 42 dias após a extração dentária. Teste estatístico ANOVA e Tukey. $(n=5)$. ** significante a $1 \%$. * significante a $5 \%$.

\begin{tabular}{|c|c|c|c|}
\hline \multicolumn{4}{|c|}{ Grupo BC + CO + OA } \\
\hline & $\mathbf{7}$ dias & $\mathbf{2 1}$ dias & 42 dias \\
\hline Tecido Mole & $33,6 \pm 2,57$ & $25,35 \pm 1,67^{\star}$ & $11,4 \pm 1,06^{\star \star}$ \\
\hline Biomaterial & $41,13 \pm 3,21$ & $39,35 \pm 2,37$ & $35,4 \pm 2,67^{\star}$ \\
\hline Osso Vital & $25,26 \pm 1,56$ & $35,3 \pm 2,7^{\star \star}$ & $53,2 \pm 2,91^{\star \star}$ \\
\hline
\end{tabular}

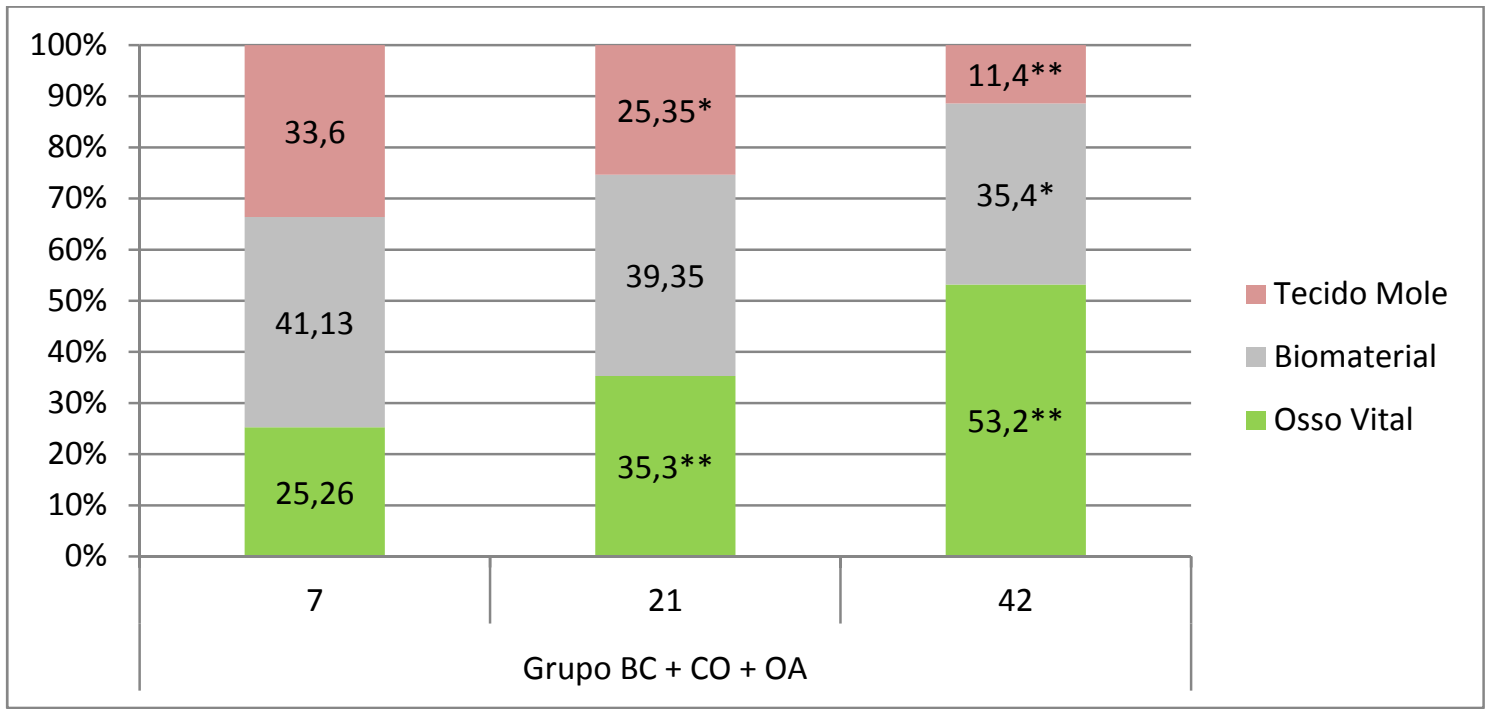

Figura 33: Média aritmética da fração volumétrica (\%) de tecido ósseo vital, biocerâmica e tecido mole (tecido conjuntivo + coágulo sanguíneo) no terço médio alveolar dos animais implantados com a biocerâmica + células osteoblásticas + osso autógeno (BC+CO+OA) no $7^{\circ}, 21^{\circ}$ e $42^{\circ}$ dia após a extração dentária. ** significante a $1 \%$. * significante a $5 \%$. 
Tabela 9: Média aritmética e desvio padrão da média referente ao volume percentual de tecido ósseo vital no terço médio alveolar dos grupos com implantação de biocerâmica (BC), biocerâmica + osso autógeno (BC+OA), biocerâmica + células osteoblásticas $(B C+C O)$ e biocerâmica + células osteoblásticas + osso autógeno (BC+CO+OA) aos 7, 21 e 42 dlias após a extração dentária. Teste estatístico ANOVA e Tukey. $(n=5)$. ${ }^{* *}$ significante a 1\%. * significante a $5 \%$.

\begin{tabular}{|c|c|c|c|c|}
\hline \multicolumn{5}{|c|}{ Tecido Ósseo Vital } \\
\hline & $\mathbf{B C}$ & $\mathbf{B C}+\mathbf{O A}$ & $\mathbf{B C}+\mathbf{C O}$ & $\mathbf{B C}+\mathbf{C O}+\mathbf{O A}$ \\
\hline $\mathbf{7}$ dias & $16,1 \pm 1,20$ & $23,2 \pm 2,03^{\star}$ & $18,5 \pm 1,56$ & $25,2 \pm 1,56^{\star \star}$ \\
\hline $\mathbf{2 1}$ dias & $28,3 \pm 2,20$ & $39,6 \pm 2,74^{\star \star}$ & $38,5 \pm 2,98^{\star \star}$ & $35,3 \pm 2,70^{\star \star}$ \\
\hline $\mathbf{4 2}$ dias & $41,7 \pm 2,16$ & $49,0 \pm 2,08^{\star \star}$ & $52,8 \pm 1,70^{\star \star}$ & $53,2 \pm 2,91^{\star \star}$ \\
\hline
\end{tabular}

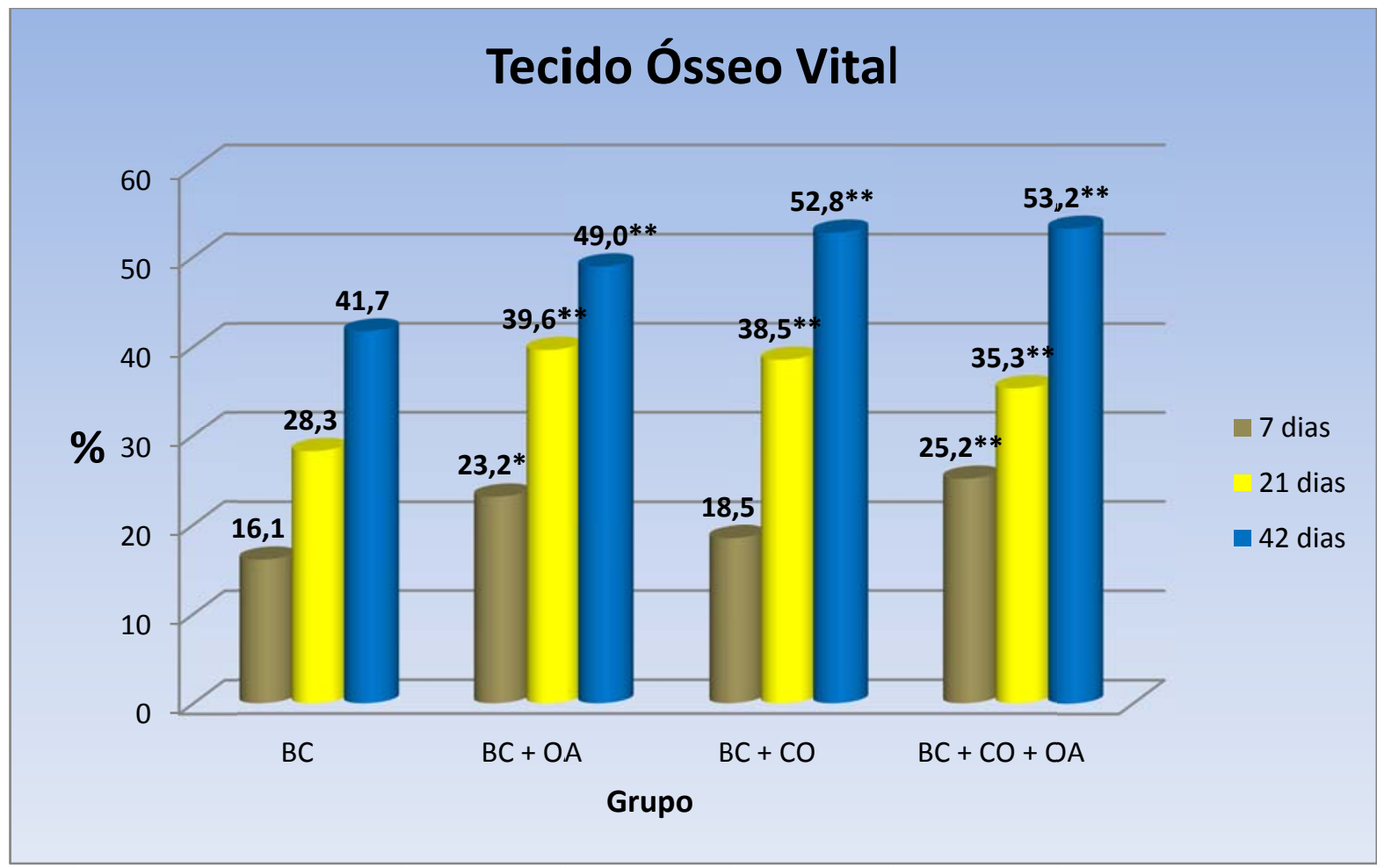

Figura 34: Média aritmética da fração volumétrica (\%) de tecido ósseo vital no terço médio alveolar dos animais implantados com biocerâmica (BC), biocerâmica + osso autógeno (BC+OA), biocerâmica + células osteoblásticas $(B C+C O)$ e biocerâmica + células osteoblásticas + osso autógeno $(B C+C O+O A)$ no $7^{\circ}, 21^{\circ}$ e $42^{\circ}$ dia após a extração dentária. ** significante a 1\%. * significante a 5\%. 
Tabela 10: Média aritmética e desvio padrão da média referente ao volume percentual de biocerâmica no terço médio alveolar dos grupos com implantação de biocerâmica $(\mathrm{BC})$, biocerâmica + osso autógeno $(\mathrm{BC}+\mathrm{OA})$, biocerâmica + células osteoblásticas $(B C+C O)$ e biocerâmica + células osteoblásticas + osso autógeno $(\mathrm{BC}+\mathrm{CO}+\mathrm{OA})$ aos 7, 21 e 42 dias após a extração dentária. Teste estatístico ANOVA e Tukey. $(n=5)$. ** significante a 1\%. * significante a $5 \%$.

\begin{tabular}{|c|c|c|c|}
\hline \multicolumn{4}{|c|}{ Biocerâmica } \\
\hline & $\mathbf{7}$ dias & 21 dias & 42 dias \\
\hline BC & $45,6 \pm 1,37$ & $42,3 \pm 3,1$ & $35,8 \pm 2,88^{\star \star}$ \\
\hline BC + OA & $45,6 \pm 2,12$ & $42,2 \pm 2,33$ & $39,9 \pm 2,09^{\star}$ \\
\hline BC + CO & $44,8 \pm 2,11$ & $43,3 \pm 2,61$ & $36,48 \pm 1,07^{\star \star}$ \\
\hline BC + CO + OA & $41,1 \pm 3,21$ & $39,3 \pm 2,37$ & $35,4 \pm 2,67^{\star}$ \\
\hline
\end{tabular}

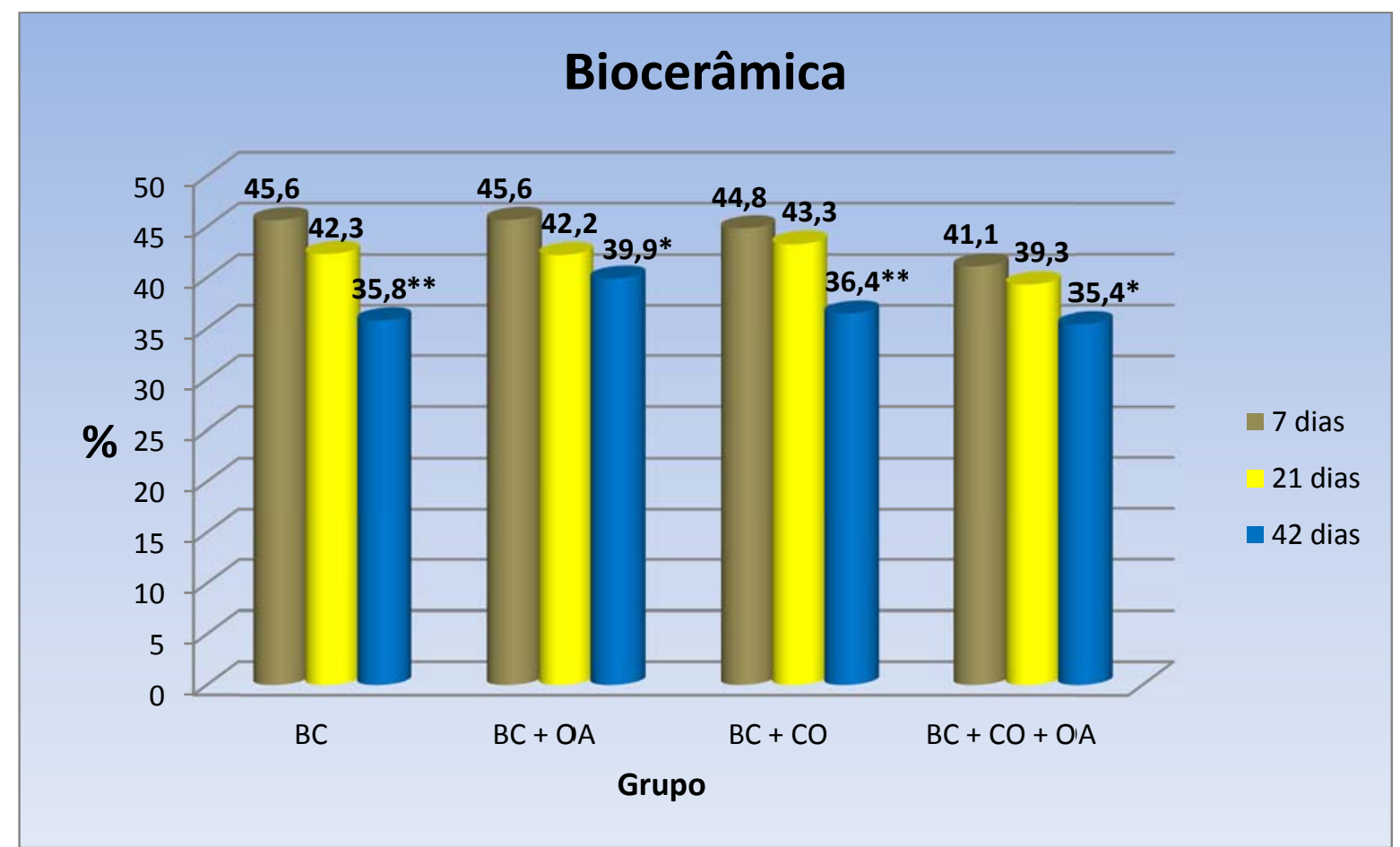

Figura 35: Média aritmética da fração volumétrica (\%) de biocerâmica no terço médio alveolar dos animais implantados com biocerâmica (BC), biocerâmica + osso autógeno $(B C+O A)$, biocerâmica + células osteoblásticas $(B C+C O)$ e biocerâmica + células osteoblásticas + osso autógeno $(B C+C O+O A)$ no $7^{\circ}, 21^{\circ}$ e $42^{\circ}$ dia após a extração dentária. ${ }^{* *}$ significante a 1\%. * significante a $5 \%$. 
Tabela 11: Média aritmética e desvio padrão da média referente ao volume percentual de tecido mole (tecido conjuntivo + coágulo sanguíneo) no terço médio alveolar dos grupos com implantação de biocerâmica (BC), biocerâmica + osso autógeno $(\mathrm{BC}+\mathrm{OA})$, biocerâmica + células osteoblásticas $(\mathrm{BC}+\mathrm{CO})$ e biocerâmica + células osteoblásticas + osso autógeno $(B C+C O+O A)$ aos 7, 21 e 42 dias após a extração dentária. Teste estatístico ANOVA e Tukey. $(n=5)$. ** significante a 1\%. * significante a $5 \%$.

\begin{tabular}{|c|c|c|c|}
\hline \multicolumn{4}{|c|}{ Tecido Mole } \\
\hline & $\mathbf{7}$ dias & $\mathbf{2 1}$ dias & $\mathbf{4 2}$ dias \\
\hline BC & $38,2 \pm 2,3$ & $29,3 \pm 2,3^{\star \star}$ & $22,4 \pm 1,45^{\star \star}$ \\
\hline BC + OA & $31,1 \pm 2,11$ & $18,1 \pm 1,88^{\star \star}$ & $11,0 \pm 1,05^{\star \star}$ \\
\hline BC + CO & $36,6 \pm 2,5$ & $18,2 \pm 1,43^{\star \star}$ & $10,6 \pm 1,25^{\star \star}$ \\
\hline BC + CO + OA & $33,2 \pm 2,57$ & $25,3 \pm 1,67^{\star}$ & $11,4 \pm 1,06^{\star \star}$ \\
\hline
\end{tabular}

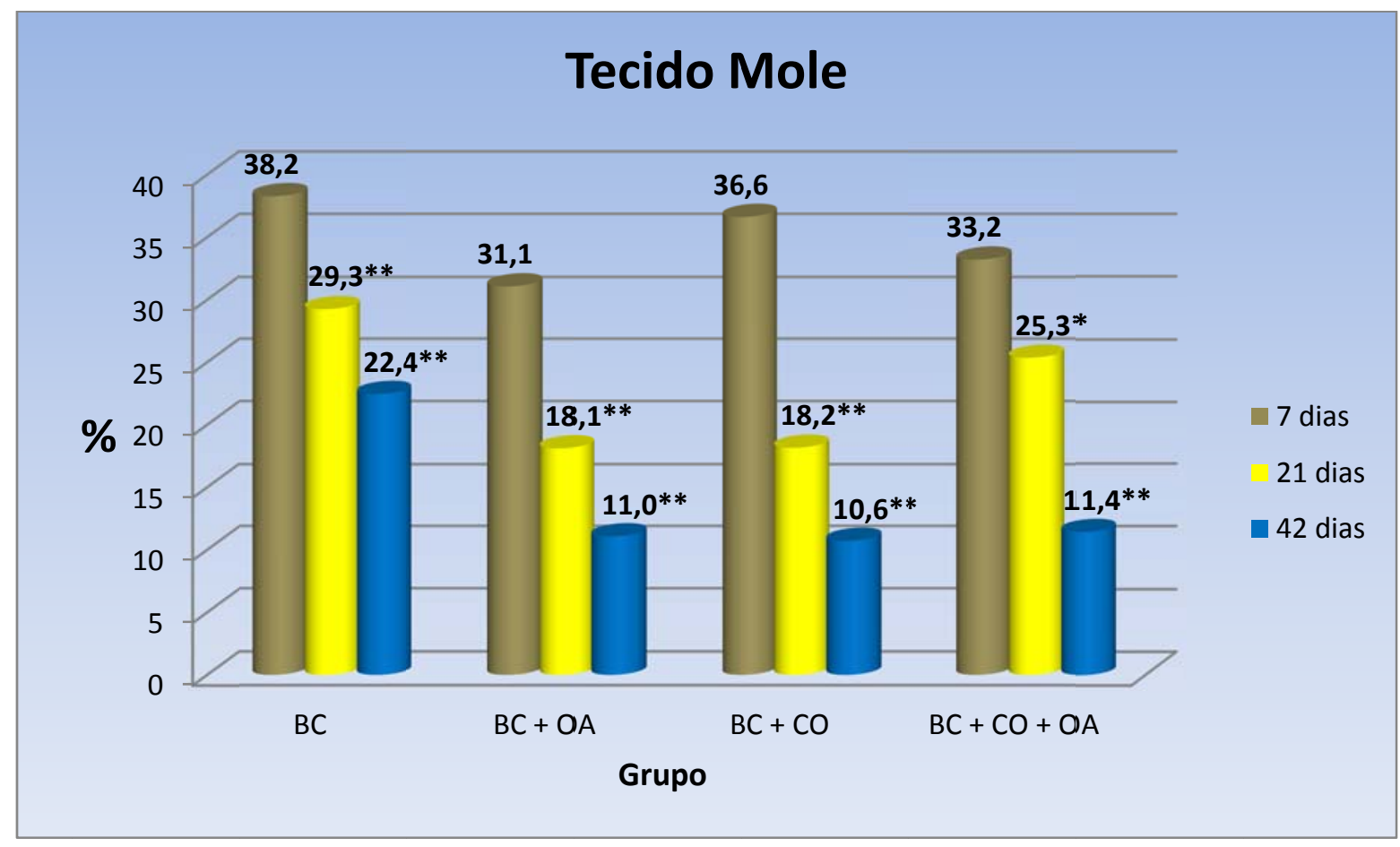

Figura 36: Média aritmética da fração volumétrica (\%) de tecido mole (tecido conjuntivo + coágulo sanguíneo) no terço médio alveolar dos animais implantados com biocerâmica $(\mathrm{BC})$, biocerâmica + osso autógeno ( $\mathrm{BC}+\mathrm{OA})$, biocerâmica + células osteoblásticas $(\mathrm{BC}+\mathrm{CO})$ e biocerâmica + células osteoblásticas + osso autógeno $(\mathrm{BC}+\mathrm{CO}+\mathrm{OA})$ no $7^{\circ}, 21^{\circ}$ e $42^{\circ}$ dia após a extração dentária. ** significante a $1 \%$. * significante a $5 \%$. 
Tabela 12: Relação osso vital/biocerâmica entre os diversos grupos que receberam a implantação da biocerâmica isolada ou em associação ao osso autógeno, células osteoblásticas ou ambos os materiais de enxerto nos períodos de 7, 21 e 42 dias. OA - osso autógeno; CO - células osteoblásticas; BC biocerâmica. Teste estatístico ANOVA e Tukey. Comparações realizadas com o grupo BC de cada período específico. ** significante a 1\%. * significante a 5\%.

\begin{tabular}{|c|c|c|c|c|}
\hline & \multicolumn{4}{|c|}{ Relação Osso Vital / Biocerâmica } \\
\hline & BC & BC+OA & BC+Co & BC+CO+OA \\
\hline $\mathbf{7}$ dias & 0,35 & $0,5^{\star}$ & 0,41 & $0,61^{\star \star}$ \\
\hline $\mathbf{2 1}$ dias & 0,66 & $0,93^{\star \star}$ & $0,88^{\star \star}$ & $0,89^{\star \star}$ \\
\hline $\mathbf{4 2}$ dias & 1,16 & $1,22^{\star \star}$ & $1,44^{\star \star}$ & $1,5^{\star \star}$ \\
\hline
\end{tabular}

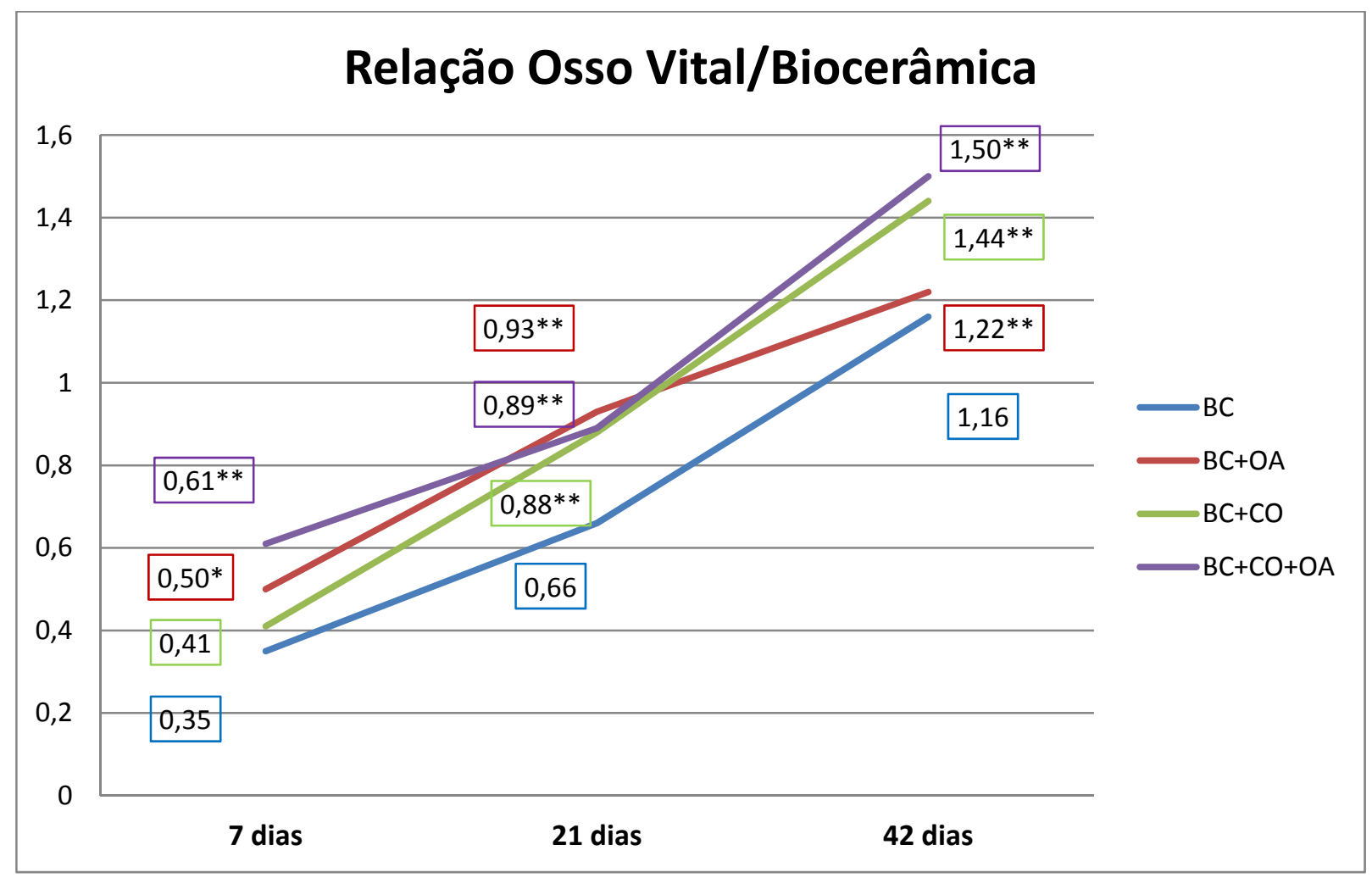

Figura 37: Progressão gráfica do potencial osteogênico obtido através da relação osso vital/biocerâmica entre os diversos grupos que receberam a implantação da biocerâmica isolada ou em associação ao osso autógeno, células osteoblásticas ou ambos os materiais de enxerto nos períodos de 7, 21 e 42 dias. OA - osso autógeno; CO - células osteoblásticas; BC - biocerâmica. Teste estatístico ANOVA e Tukey. Comparações realizadas com o grupo BC de cada período específico. ** significante a $1 \%$. * significante a $5 \%$. 
Tabela 13: Comparações múltiplas entre os diversos grupos que receberam a implantação da biocerâmica isolada ou em associação, através do teste estatístico ANOVA e Tukey para a porcentagem de tecido ósseo vital no terço médio alveolar em 7, 21 e 42 dias (significância descrita na tabela). OA - osso autógeno; CO células osteoblásticas; BC - biocerâmica.

\section{Tecido Ósseo Vital}

\begin{tabular}{cccc}
\hline Grupos & 7 dias & 21 dias & 42 dias \\
\hline BC $\times$ BCOA & $5 \%$ & $1 \%$ & $1 \%$ \\
BC $\times$ BCCO & n.s. & $1 \%$ & $1 \%$ \\
BC $\times$ BCCOOA & $1 \%$ & $1 \%$ & $1 \%$ \\
BCOA $\times$ BCCO & $5 \%$ & n.s. & n.s. \\
BCOA $\times$ BCCOOA & n.s. & n.s. & n.s. \\
BCCO $\times$ BCCOOA & $1 \%$ & n.s. & n.s. \\
\hline
\end{tabular}

$\underline{\text { n.S. - não significante }}$

Tabela 14: Comparações múltiplas entre os diversos grupos que receberam a implantação da biocerâmica isolada ou em associação, através do teste estatístico ANOVA e Tukey para a porcentagem de biocerâmica no terço médio alveolar em 7, 21 e 42 dias (significância descrita na tabela). OA - osso autógeno; CO - células osteoblásticas; BC - biocerâmica.

\section{Biocerâmica}

\begin{tabular}{cccc}
\hline Grupos & 7 dias & 21 dias & 42 dias \\
\hline BC $\times$ BCOA & n.s. & n.s. & n.s. \\
BC $\times$ BCCO & n.s. & n.s. & n.s. \\
BC $\times$ BCCOOA & n.s. & n.s. & n.s. \\
BCOA $\times$ BCCO & n.s. & n.s. & n.s. \\
BCOA $\times$ BCCOOA & n.s. & n.s. & n.s. \\
BCCO $\times$ BCCOOA & n.s. & n.s. & n.s. \\
\hline
\end{tabular}

$\underline{\text { n.S. - não significante }}$ 
Tabela 15: Comparações múltiplas entre os diversos grupos que receberam a implantação da biocerâmica isolada ou em associação, através do teste estatístico ANOVA e Tukey para a porcentagem de tecido mole no terço médio alveolar em 7, 21 e 42 dias (significância descrita na tabela). OA - osso autógeno; CO - células osteoblásticas; BC - biocerâmica.

\section{Tecido Mole}

\begin{tabular}{cccc}
\hline Grupos & 7 dias & 21 dias & 42 dias \\
\hline BC $\times$ BCOA & $5 \%$ & $1 \%$ & $1 \%$ \\
BC x BCCO & n.s. & $1 \%$ & $1 \%$ \\
BC x BCCOОA & $5 \%$ & n.s. & $1 \%$ \\
BCOA x BCCO & n.s. & n.s. & n.s. \\
BCOA x BCCOOA & n.s. & $5 \%$ & n.s. \\
BCCO x BCCOOA & n.s. & $5 \%$ & n.s. \\
\hline
\end{tabular}

$\underline{\text { n.S. - não significante }}$

Tabela 16: Comparações múltiplas entre os diversos períodos de estudo para os grupos que receberam a implantação da biocerâmica isolada ou em associação, através do teste estatístico ANOVA e Tukey para a porcentagem de tecido ósseo, biocerâmica e tecido mole no terço médio alveolar dos animais. (significância descrita na tabela). OA - osso autógeno; CO - células osteoblásticas; BC biocerâmica.

\begin{tabular}{|c|c|c|c|c|c|c|c|c|c|}
\hline \multirow[t]{2}{*}{ Grupos } & \multicolumn{3}{|c|}{ Tecido ósseo vital } & \multicolumn{3}{|c|}{ Biocerâmica } & \multicolumn{3}{|c|}{ Tecido Mole } \\
\hline & $7 \times 21$ & $7 \times 42$ & $21 \times 42$ & $7 \times 21$ & $7 \times 42$ & $21 \times 42$ & $7 \times 21$ & $7 \times 42$ & $21 \times 42$ \\
\hline BC & $1 \%$ & $1 \%$ & $1 \%$ & n.s. & $1 \%$ & n.s. & $1 \%$ & $1 \%$ & $5 \%$ \\
\hline BCOA & $1 \%$ & $1 \%$ & $1 \%$ & n.s. & $5 \%$ & n.s. & $1 \%$ & $1 \%$ & $1 \%$ \\
\hline BCCO & $1 \%$ & $1 \%$ & $1 \%$ & n.s. & $1 \%$ & n.s. & $1 \%$ & $1 \%$ & $1 \%$ \\
\hline BCCOOA & $1 \%$ & $1 \%$ & $1 \%$ & n.s. & $5 \%$ & n.s. & $5 \%$ & $1 \%$ & $1 \%$ \\
\hline
\end{tabular}

n.s. - não significante 


\subsubsection{Tecido Conjuntivo}

Na tabela 17 e na figura 38 são expressos os valores médios e desvio padrão da média do volume percentual de tecido conjuntivo dos grupos controle, osso autógeno, células osteoblásticas, osso autógeno + células osteoblásticas, biocerâmica, biocerâmica + osso autógeno, biocerâmica + células osteoblásticas, e biocerâmica + células osteoblásticas + osso autógeno, 7 dias após a extração dentária. Pode-se observar um menor volume de tecido conjuntivo nos grupos onde a biocerâmica foi implantada (BC; $\mathrm{BC}+\mathrm{OA} ; \mathrm{BC}+\mathrm{CO} ; \mathrm{BC}+\mathrm{CO}+\mathrm{OA}$ ) quando comparados ao grupo controle (significante a 1\%), e também em relação aos animais implantados com OA, CO e OA+CO (significante a 5\%).

Na tabela 18 e na figura 39 são expressos os valores médios e desvio padrão da média do volume percentual de tecido conjuntivo dos grupos controle, osso autógeno, células osteoblásticas, osso autógeno + células osteoblásticas, biocerâmica, biocerâmica + osso autógeno, biocerâmica + células osteoblásticas, e biocerâmica + células osteoblásticas + osso autógeno, 21 dias após a extração dentária. Os dados analisados demonstraram menor porcentagem de tecido conjuntivo nos grupos $\mathrm{BC}+\mathrm{OA}$ e $\mathrm{BC}+\mathrm{CO}$ (significante a 1\%) e, $\mathrm{BC}$ e $\mathrm{BC}+\mathrm{CO}+\mathrm{OA}$ (significante a 5\%) quando comparados aos animais controle (Tabela 20). Menores valores da porcentagem de tecido conjuntivo para todos os grupos foram encontrados quando comparados ao período de 7 dias.

Na tabela 19 e na figura 40 são expressos os valores médios e desvio padrão da média do volume percentual de tecido conjuntivo dos grupos controle, osso autógeno, células osteoblásticas, osso autógeno + células osteoblásticas, biocerâmica, biocerâmica + osso autógeno, biocerâmica + células osteoblásticas, e 
biocerâmica + células osteoblásticas + osso autógeno, 42 dias após a extração dentária. Os resultados mostraram uma menor porcentagem de tecido conjuntivo quando comparados aos períodos de 7 e 21 dias, independente do tratamento utilizado. Em relação aos animais controle, a análise feita aos 42 dias revelou menores valores percentuais de preenchimento com tecido conjuntivo nos grupos $\mathrm{CO}, \mathrm{BC}, \mathrm{BC}+\mathrm{OA} ; \mathrm{BC}+\mathrm{CO}$ e $\mathrm{BC}+\mathrm{CO}+\mathrm{OA}$ (sem significância estatística), exceto para o grupo osso autógeno que apresentou valores superiores (significantes a 1\%).

A análise estatística através de comparações múltiplas entre os grupos estudados nos períodos de 7, 21 e 42 dias, quanto à porcentagem volumétrica de tecido conjuntivo intra-alveolar foi realizada através do teste estatístico ANOVA e Tukey, levando em consideração níveis de significância de 1\% e 5\% (Tabela 20). 
Tabela 17: Média aritmética e desvio padrão da média referente ao volume percentual de tecido conjuntivo dos grupos: controle, osso autógeno (OA), células osteoblásticas ( $\mathrm{CO})$, osso autógeno + células osteoblásticas (OA+CO), biocerâmica $(\mathrm{BC})$, biocerâmica + osso autógeno $(\mathrm{BC}+\mathrm{OA})$, biocerâmica + células osteoblásticas $(\mathrm{BC}+\mathrm{CO})$, e biocerâmica + células osteoblásticas + osso autógeno $(\mathrm{BC}+\mathrm{CO}+\mathrm{OA}) 7$ dias após a extração dentária. Teste estatístico ANOVA e Tukey. $(n=5)$. ** significante a $1 \%$.

\begin{tabular}{|c|c|c|c|c|c|c|c|}
\hline \multicolumn{7}{|c|}{ Tecido Conjuntivo - 7 dias } \\
\hline Controle & OA & Co & OA+CO & BC & BC+OA & BC+CO & BC+CO+OA \\
\hline 54,4 & 45,1 & 44,7 & 47,2 & 38,2 & 38,2 & 40,7 & 39,1 \\
\pm & \pm & \pm & \pm & \pm & \pm & \pm & \pm \\
1,29 & 1,39 & $1,04^{\star *}$ & 2,07 & $1,84^{\star *}$ & $2,26^{\star *}$ & $2,04^{\star *}$ & $2,3^{\star *}$ \\
\hline
\end{tabular}

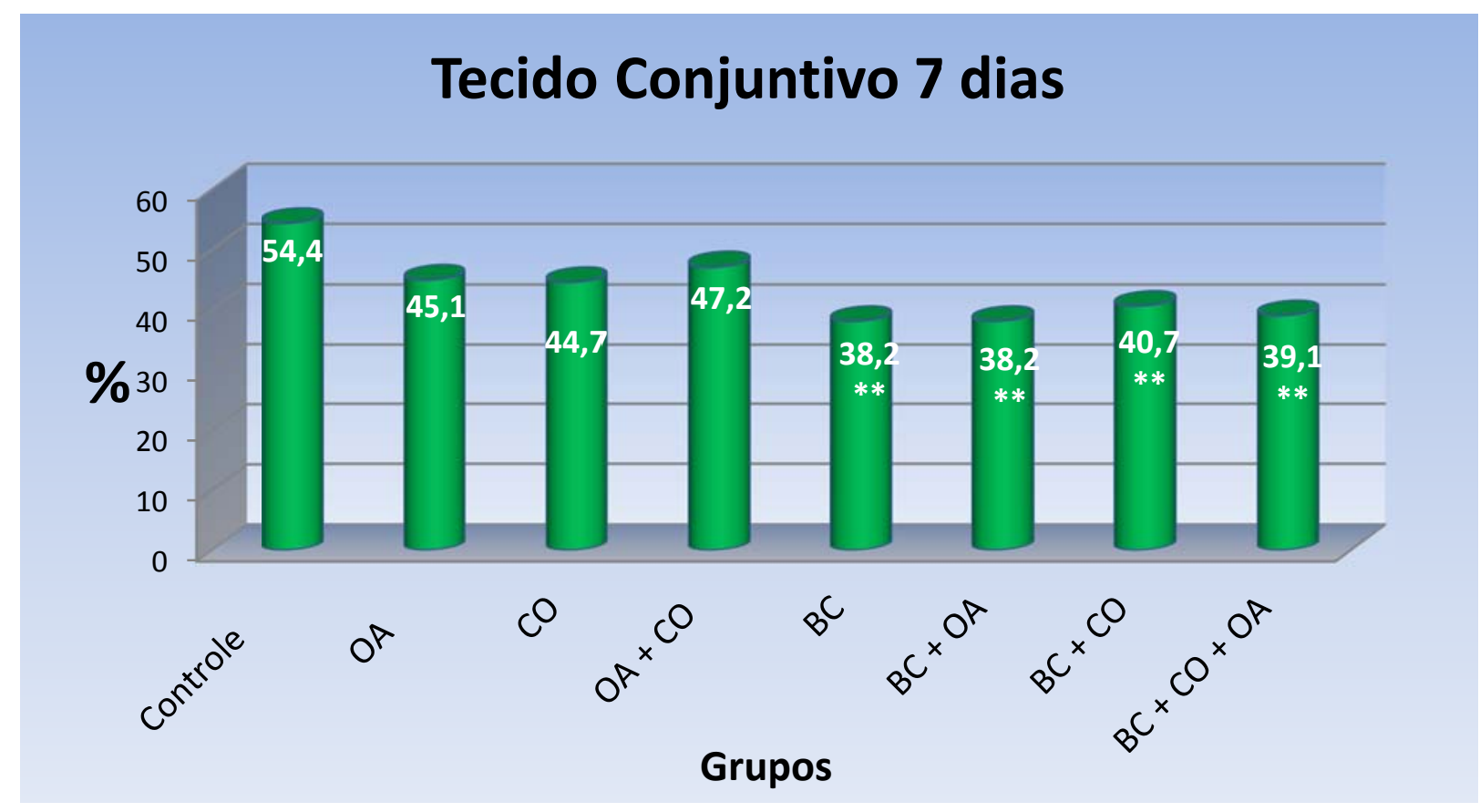

Figura 38: Média aritmética da fração de volume (\%) de tecido conjuntivo no alvéolo dentário dos animais controle, osso autógeno (OA), células osteoblásticas (CO), osso autógeno + células osteoblásticas (OA+CO), biocerâmica $(\mathrm{BC})$, biocerâmica + osso autógeno ( $\mathrm{BC}+\mathrm{OA})$, biocerâmica + células osteoblásticas $(\mathrm{BC}+\mathrm{CO})$, e biocerâmica + células osteoblásticas + osso autógeno (BC+CO+OA), 7 dias após a extração dentária. ** significante a 1\%. 
Tabela 18: Média aritmética e desvio padrão da média referente ao volume percentual de tecido conjuntivo dos grupos: controle, osso autógeno (OA), células osteoblásticas $(\mathrm{CO})$, osso autógeno + células osteoblásticas $(\mathrm{OA}+\mathrm{CO})$, biocerâmica $(\mathrm{BC})$, biocerâmica + osso autógeno $(\mathrm{BC}+\mathrm{OA})$, biocerâmica + células osteoblásticas $(\mathrm{BC}+\mathrm{CO})$, e biocerâmica + células osteoblásticas + osso autógeno (BC+CO+OA) 21 dias após a extração dentária. Teste estatístico ANOVA e Tukey. $(n=5)$. ** significante a $1 \%$. * significante a $5 \%$.

\begin{tabular}{|c|c|c|c|c|c|c|c|}
\hline \multicolumn{7}{|c|}{ Tecido Conjuntivo - 21 dias } \\
\hline Controle & OA & Co & OA+CO & BC & BC+OA & BC+Co & BC+CO+OA \\
\hline 39,9 & 40,9 & 35,7 & 42,8 & 34,8 & 31,6 & 30,5 & 34,9 \\
\pm & \pm & \pm & $1 \pm$ & \pm & \pm & \pm & \pm \\
1,29 & 1,39 & 1,04 & 2,07 & $1,84^{*}$ & $2,26^{* *}$ & $2,04^{* *}$ & $2,3^{*}$ \\
\hline
\end{tabular}

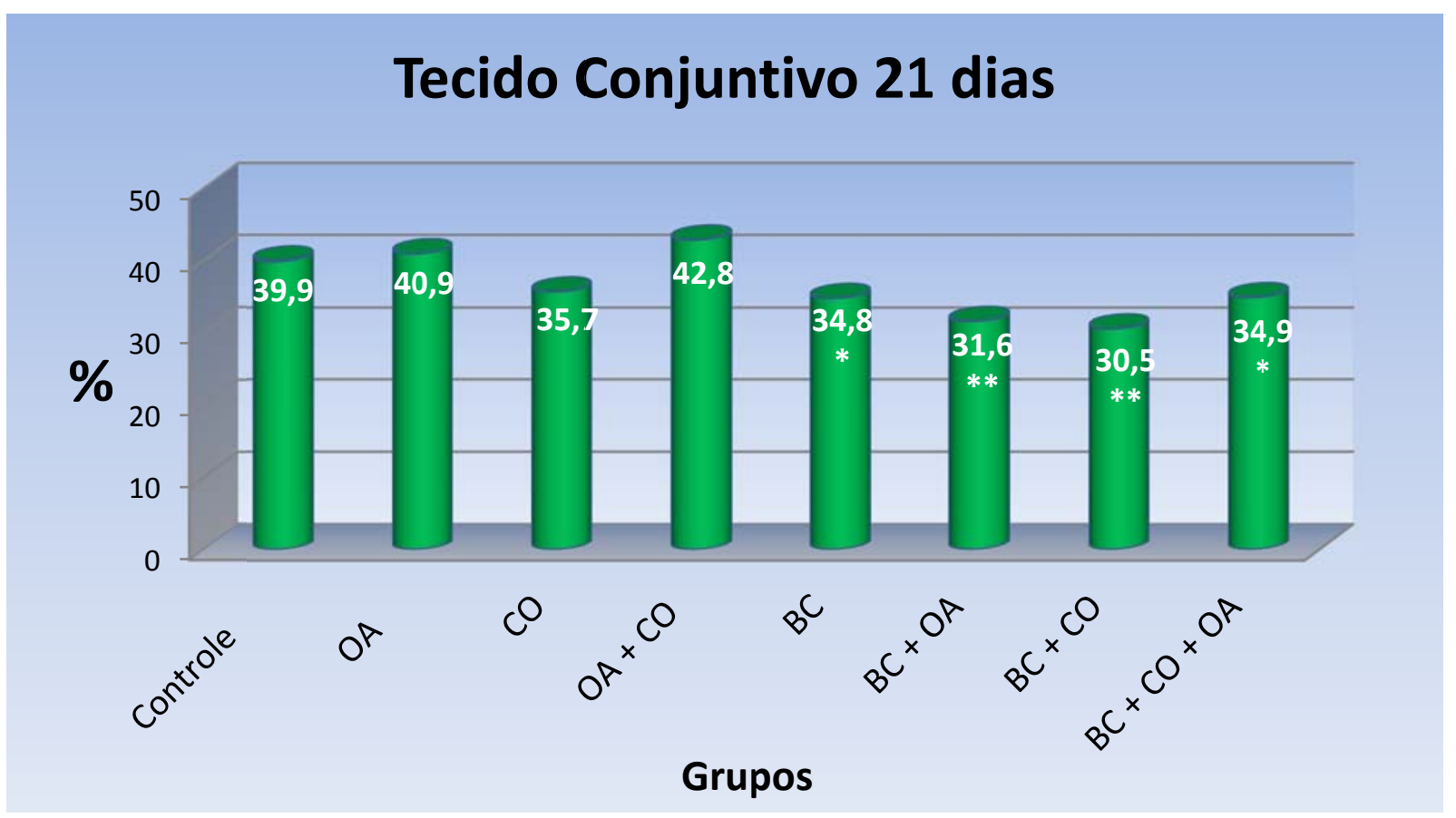

Figura 39: Média aritmética da fração de volume (\%) de tecido conjuntivo no alvéolo dentário dos animais controle, osso autógeno (OA), células osteoblásticas $(\mathrm{CO})$, osso autógeno + células osteoblásticas $(\mathrm{OA}+\mathrm{CO})$, biocerâmica $(\mathrm{BC})$, biocerâmica + osso autógeno $(\mathrm{BC}+\mathrm{OA})$, biocerâmica + células osteoblásticas $(\mathrm{BC}+\mathrm{CO})$, e biocerâmica + células osteoblásticas + osso autógeno $(\mathrm{BC}+\mathrm{CO}+\mathrm{OA}), 21$ dias após a extração dentária. ${ }^{* *}$ significante a $1 \% .{ }^{*}$ significante a $5 \%$. 
Tabela 19: Média aritmética e desvio padrão da média referente ao volume percentual de tecido conjuntivo dos grupos: controle, osso autógeno (OA), células osteoblásticas $(\mathrm{CO})$, osso autógeno + células osteoblásticas $(\mathrm{OA}+\mathrm{CO})$, biocerâmica $(\mathrm{BC})$, biocerâmica + osso autógeno $(\mathrm{BC}+\mathrm{OA})$, biocerâmica + células osteoblásticas $(\mathrm{BC}+\mathrm{CO})$, e biocerâmica + células osteoblásticas + osso autógeno (BC+CO+OA) 42 dias após a extração dentária. Teste estatístico ANOVA e Tukey. $(n=5)$. ** significante a $1 \%$.

\begin{tabular}{|c|c|c|c|c|c|c|c|}
\hline \multicolumn{7}{|c|}{ Tecido Conjuntivo - 42 dias } \\
\hline Controle & OA & CO & OA+CO & BC & BC+OA & BC+CO & BC+CO+OA \\
\hline 28,0 & 36,7 & 26,7 & 28,6 & 25,4 & 24,5 & 23,3 & 23,5 \\
\pm & \pm & \pm & \pm & \pm & \pm & \pm & \pm \\
1,29 & $1,39^{* *}$ & 1,04 & 2,07 & 1,84 & 2,26 & 2,04 & 2,3 \\
\hline
\end{tabular}

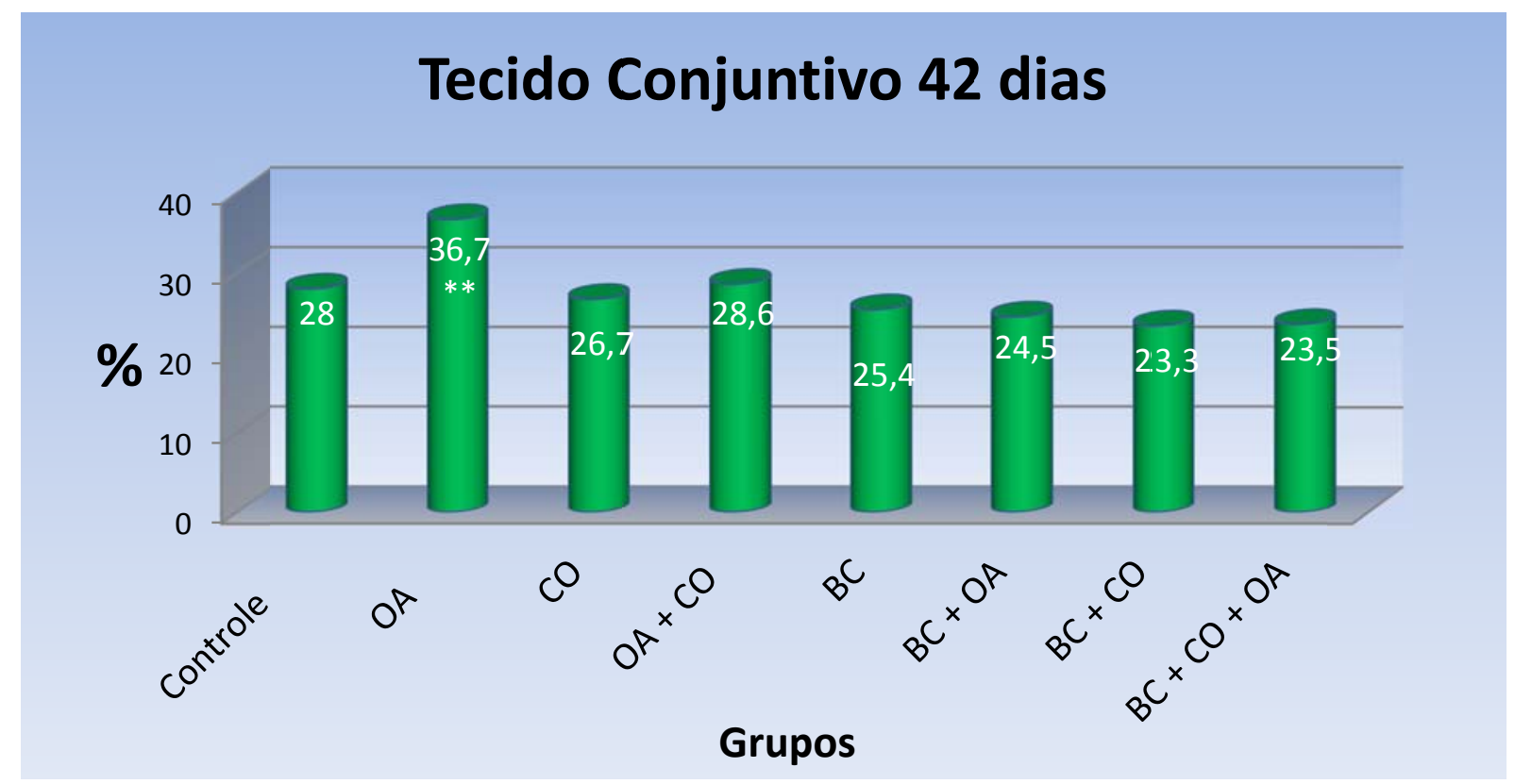

Figura 40: Média aritmética da fração de volume (\%) de tecido conjuntivo no alvéolo dentário dos animais controle, osso autógeno (OA), células osteoblásticas $(\mathrm{CO})$, osso autógeno + células osteoblásticas $(\mathrm{OA}+\mathrm{CO})$, biocerâmica $(\mathrm{BC})$, biocerâmica + osso autógeno $(\mathrm{BC}+\mathrm{OA})$, biocerâmica + células osteoblásticas $(\mathrm{BC}+\mathrm{CO})$, e biocerâmica + células osteoblásticas + osso autógeno $(\mathrm{BC}+\mathrm{CO}+\mathrm{OA}), 42$ dias após a extração dentária. ${ }^{* *}$ significante a $1 \%$. 
Tabela 20: Comparações múltiplas entre os diversos grupos estudados através do teste estatístico ANOVA e Tukey para a porcentagem de tecido conjuntivo em 7, 21 e 42 dias (significância descrita na tabela). C - controle; OA - osso autógeno; CO células osteoblásticas; BC - biocerâmica.

\section{Tecido Conjuntivo}

\begin{tabular}{|c|c|c|c|}
\hline Grupos & 7 dias & 21 dias & 42 dias \\
\hline $\mathrm{C} \times \mathrm{OA}$ & $5 \%$ & n.s. & $1 \%$ \\
\hline $\mathrm{C} \times \mathrm{CO}$ & $5 \%$ & n.s. & n.s. \\
\hline $\mathrm{C} \times \mathrm{OACO}$ & $5 \%$ & n.s. & n.s. \\
\hline $\mathrm{C} \times \mathrm{BC}$ & $1 \%$ & $5 \%$ & n.s. \\
\hline $\mathrm{C} \times \mathrm{BCOA}$ & $1 \%$ & $1 \%$ & n.s. \\
\hline $\mathrm{C} \times \mathrm{BCCO}$ & $1 \%$ & $1 \%$ & n.s. \\
\hline $\mathrm{C} \times \mathrm{BCCOOA}$ & $1 \%$ & $5 \%$ & n.s. \\
\hline $\mathrm{OA}$ x CO & n.s. & $5 \%$ & $1 \%$ \\
\hline OA $\times$ OACO & n.s. & n.s. & $1 \%$ \\
\hline $\mathrm{OA} \times \mathrm{BC}$ & $5 \%$ & $5 \%$ & $1 \%$ \\
\hline$O A \times B C O A$ & $5 \%$ & $1 \%$ & $1 \%$ \\
\hline $\mathrm{OA}$ x BCCO & $5 \%$ & $1 \%$ & $1 \%$ \\
\hline $\mathrm{OA} \times \mathrm{BCCOOA}$ & $5 \%$ & $5 \%$ & $1 \%$ \\
\hline CO x OACO & n.s. & $1 \%$ & n.s. \\
\hline $\mathrm{CO} \times \mathrm{BC}$ & $5 \%$ & n.s. & n.s. \\
\hline $\mathrm{CO} \times \mathrm{BCOA}$ & $5 \%$ & $5 \%$ & n.s. \\
\hline $\mathrm{CO} \times \mathrm{BCCO}$ & $5 \%$ & $5 \%$ & n.s. \\
\hline $\mathrm{CO} \times \mathrm{BCCOOA}$ & $5 \%$ & n.s. & n.s. \\
\hline $\mathrm{OACO} \times \mathrm{BC}$ & $5 \%$ & $1 \%$ & n.s. \\
\hline OACO x BCOA & $5 \%$ & $1 \%$ & n.s. \\
\hline $\mathrm{OACO} \times \mathrm{BCCO}$ & $5 \%$ & $1 \%$ & n.s. \\
\hline OACO x BCCOOA & $5 \%$ & $1 \%$ & n.s. \\
\hline $\mathrm{BC} \times \mathrm{BCOA}$ & n.s. & $5 \%$ & n.s. \\
\hline $\mathrm{BC} \times \mathrm{BCCO}$ & n.s. & $5 \%$ & n.s. \\
\hline $\mathrm{BC} \times \mathrm{BCCOOA}$ & n.s. & n.s. & n.s. \\
\hline BCOA x BCCO & n.s. & n.s. & n.s. \\
\hline BCOA $\times$ BCCOOA & n.s. & $5 \%$ & n.s. \\
\hline $\mathrm{BCCO} \times \mathrm{BCCOOA}$ & n.s. & $5 \%$ & n.s. \\
\hline
\end{tabular}

n.s. - não significante 


\subsubsection{Coágulo Sanguíneo}

Na tabela 21 e na figura 41 são expressos os valores médios e desvio padrão da média do volume percentual de coágulo sanguíneo dos grupos controle, osso autógeno, células osteoblásticas, osso autógeno + células osteoblásticas, biocerâmica, biocerâmica + osso autógeno, biocerâmica + células osteoblásticas, e biocerâmica + células osteoblásticas + osso autógeno, 7 dias após a extração dentária. Quando em comparação aos animais controle não houve diferenças estatisticamente significantes na porcentagem mensurada em relação aos grupos $\mathrm{BC}+\mathrm{OA}, \mathrm{BC}+\mathrm{CO}$ e $\mathrm{BC}+\mathrm{CO}+\mathrm{OA}$, enquanto os demais grupos apresentaram valores mais altos (significantes a $1 \%$ ).

Na tabela 22 e na figura 42 são expressos os valores médios e desvio padrão da média do volume percentual de coágulo sanguíneo dos grupos controle, osso autógeno, células osteoblásticas, osso autógeno + células osteoblásticas, biocerâmica, biocerâmica + osso autógeno, biocerâmica + células osteoblásticas, e biocerâmica + células osteoblásticas + osso autógeno, 21 dias após a extração dentária. Todos os grupos analisados neste período tiveram maiores porcentagens de coágulo sanguíneo em relação ao controle, mas significantes foram os grupos BC $(5 \%)$ e CO (1\%) (Tabela 24$)$.

Na tabela 23 e na figura 43 são expressos os valores médios e desvio padrão da média do volume percentual de coágulo sanguíneo dos grupos controle, osso autógeno, células osteoblásticas, osso autógeno + células osteoblásticas, biocerâmica, biocerâmica + osso autógeno, biocerâmica + células osteoblásticas, e biocerâmica + células osteoblásticas + osso autógeno, 42 dias após a extração dentária. Neste período praticamente não foi possível mensurar coágulo sanguíneo 
nos animais controle, $\mathrm{BC}+\mathrm{OA}, \mathrm{BC}+\mathrm{CO}$ e $\mathrm{BC}+\mathrm{CO}+\mathrm{OA}$, enquanto os demais grupos possuíam porcentagens também baixas.

A análise estatística através de comparações múltiplas entre os grupos estudados nos períodos de 7, 21 e 42 dias, quanto à porcentagem volumétrica de coágulo sanguíneo intra-alveolar foi realizada através do teste estatístico ANOVA e Tukey, levando em consideração níveis de significância de 1\% e 5\% (Tabela 24). 
Tabela 21: Média aritmética e desvio padrão da média referente ao volume percentual de coágulo sanguíneo dos grupos: controle, osso autógeno (OA), células osteoblásticas $(\mathrm{CO})$, osso autógeno + células osteoblásticas $(\mathrm{OA}+\mathrm{CO})$, biocerâmica $(\mathrm{BC})$, biocerâmica + osso autógeno $(\mathrm{BC}+\mathrm{OA})$, biocerâmica + células osteoblásticas $(\mathrm{BC}+\mathrm{CO})$ e biocerâmica + células osteoblásticas + osso autógeno $(\mathrm{BC}+\mathrm{CO}+\mathrm{OA}) 7$ dias após a extração dentária. Teste estatístico ANOVA e Tukey. $(n=7) .{ }^{* *}$ significante a $1 \%$.

\begin{tabular}{|c|c|c|c|c|c|c|c|}
\hline \multicolumn{7}{|c|}{ Coágulo Sanguíneo - 7 dias } \\
\hline Controle & OA & Co & OA+Co & BC & BC+OA & BC+Co & BC+CO+OA \\
\hline 11,7 & 18,8 & 17,3 & 19,7 & 22,5 & 13,3 & 12,9 & 8,4 \\
\pm & \pm & \pm & \pm & \pm & \pm & \pm & \pm \\
1,29 & $1,39^{* *}$ & $1,04^{* *}$ & $2,07^{* *}$ & $1,84^{* *}$ & 2,26 & 2,04 & 2,3 \\
\hline
\end{tabular}

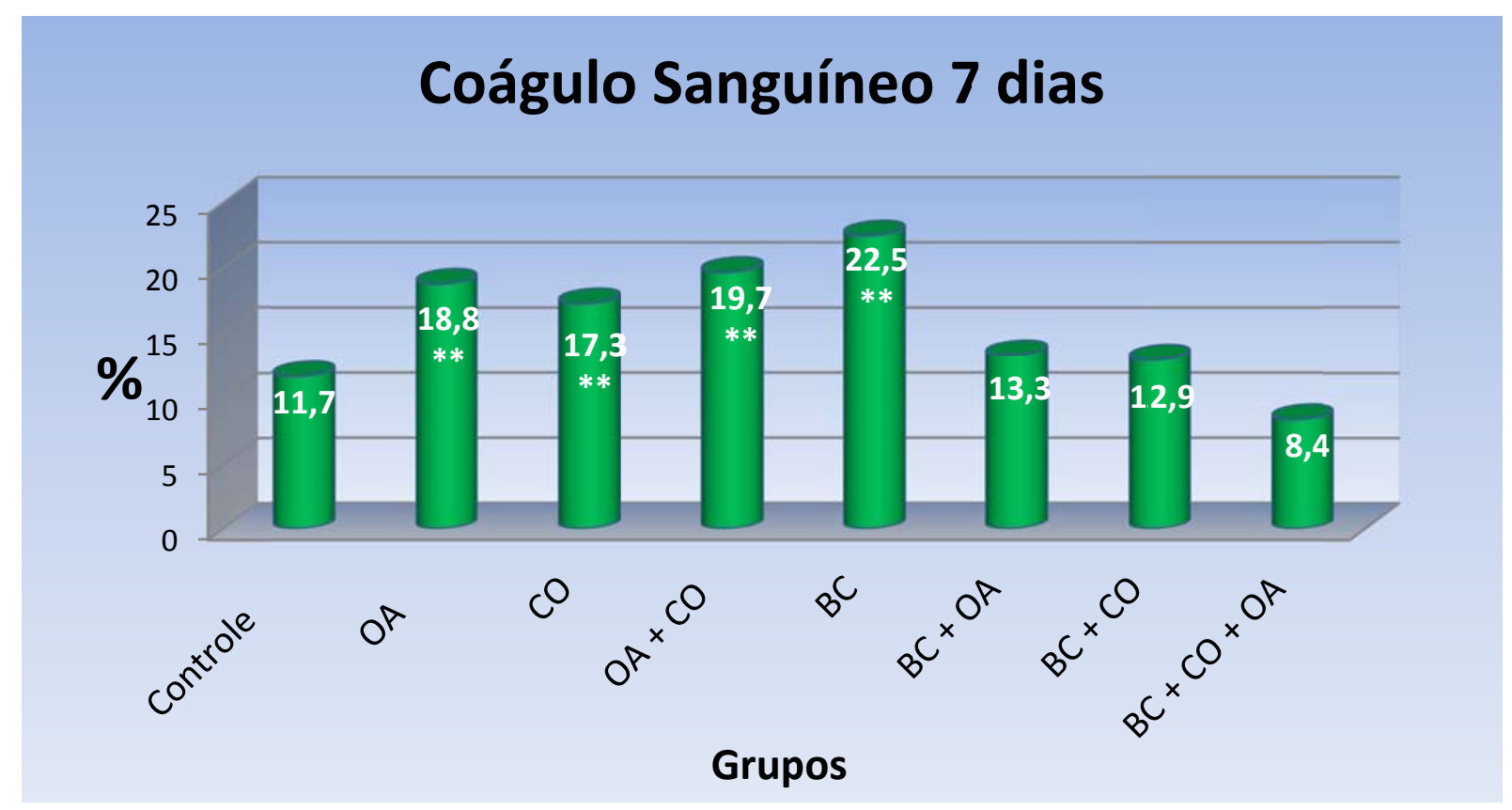

Figura 41: Média aritmética da fração de volume (\%) de coágulo sanguíneo no alvéolo dentário dos animais controle, osso autógeno (OA), células osteoblásticas (CO), osso autógeno + células osteoblásticas $(\mathrm{OA}+\mathrm{CO})$, biocerâmica $(\mathrm{BC})$, biocerâmica + osso autógeno $(B C+O A)$, biocerâmica + células osteoblásticas $(\mathrm{BC}+\mathrm{CO})$, e biocerâmica + células osteoblásticas + osso autógeno $(\mathrm{BC}+\mathrm{CO}+\mathrm{OA}), 7$ dias após a extração dentária. ** significante a $1 \%$. 
Tabela 22: Média aritmética e desvio padrão da média referente ao volume percentual de coágulo sanguíneo dos grupos: controle, osso autógeno (OA), células osteoblásticas $(\mathrm{CO})$, osso autógeno + células osteoblásticas $(\mathrm{OA}+\mathrm{CO})$, biocerâmica $(\mathrm{BC})$, biocerâmica + osso autógeno $(\mathrm{BC}+\mathrm{OA})$, biocerâmica + células osteoblásticas $(\mathrm{BC}+\mathrm{CO})$ e biocerâmica + células osteoblásticas + osso autógeno $(\mathrm{BC}+\mathrm{CO}+\mathrm{OA}) \mathbf{2 1}$ dias após a extração dentária. Teste estatístico ANOVA e Tukey. $(n=7) .{ }^{* *}$ significante a $1 \%$. * significante a $5 \%$.

\begin{tabular}{|c|c|c|c|c|c|c|c|}
\hline \multicolumn{7}{|c|}{ Coágulo Sanguíneo - 21 dias } \\
\hline Controle & OA & Co & OA+Co & BC & BC+OA & BC+Co & BC+CO+OA \\
\hline 1,4 & 4,6 & 11,9 & 1,8 & 7,7 & 2,6 & 2,7 & 5,7 \\
\pm & \pm & \pm & \pm & \pm & \pm & \pm & \pm \\
1,29 & $1,39^{*}$ & $1,04^{* *}$ & 2,07 & $1,84^{* *}$ & 2,26 & 2,04 & $2,3^{* *}$ \\
\hline
\end{tabular}

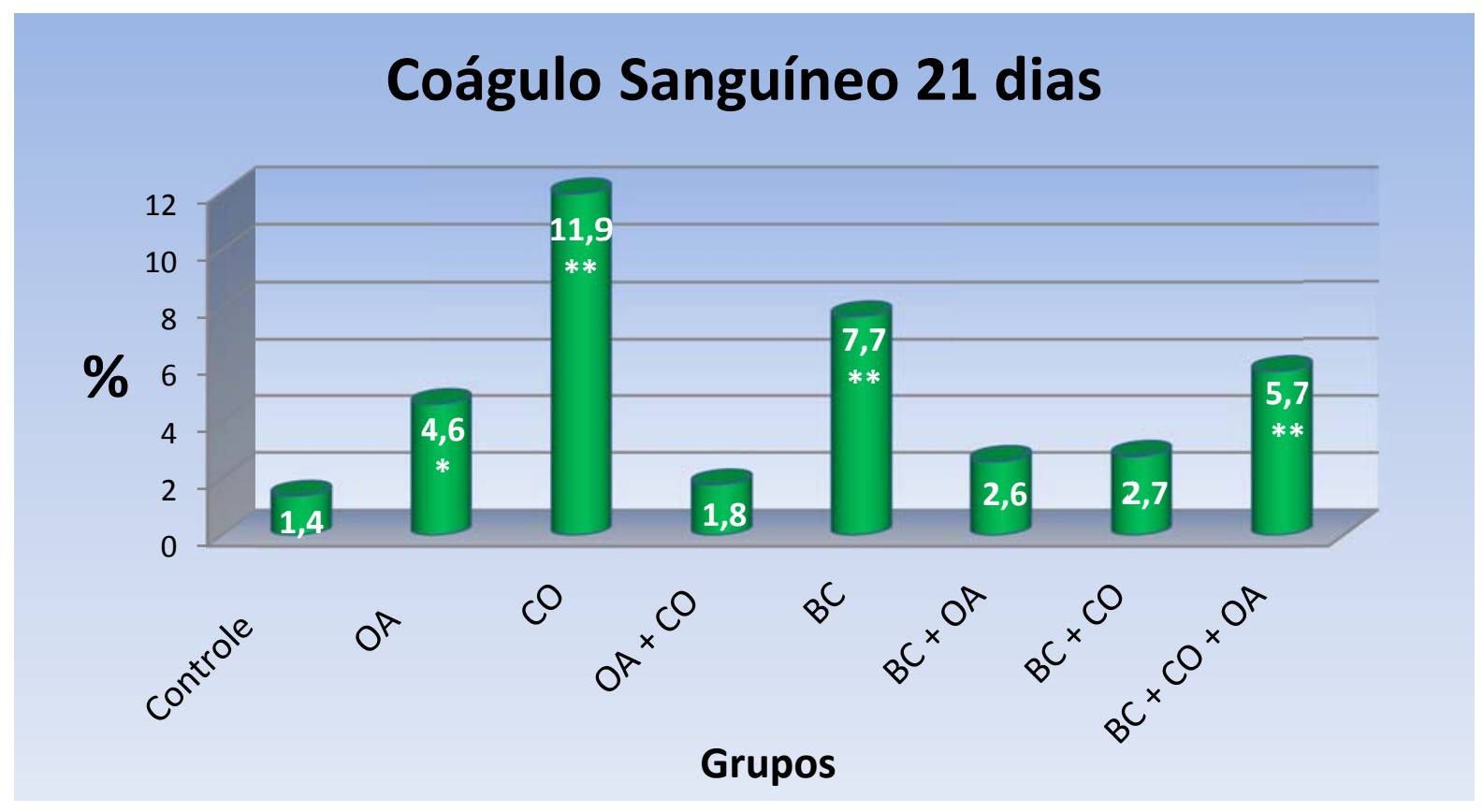

Figura 42: Média aritmética da fração de volume (\%) de coágulo sanguíneo no alvéolo dentário dos animais controle, osso autógeno (OA), células osteoblásticas $(\mathrm{CO})$, osso autógeno + células osteoblásticas $(\mathrm{OA}+\mathrm{CO})$, biocerâmica $(\mathrm{BC})$, biocerâmica + osso autógeno ( $\mathrm{BC}+\mathrm{OA})$, biocerâmica + células osteoblásticas $(\mathrm{BC}+\mathrm{CO})$, e biocerâmica + células osteoblásticas + osso autógeno (BC+CO+OA), 21 dias após a extração dentária. ${ }^{* *}$ significante a $1 \%$. * significante a $5 \%$. 
Tabela 23: Média aritmética e desvio padrão da média referente ao volume percentual de coágulo sanguíneo dos grupos: controle, osso autógeno (OA), células osteoblásticas $(\mathrm{CO})$, osso autógeno + células osteoblásticas $(\mathrm{OA}+\mathrm{CO})$, biocerâmica $(\mathrm{BC})$, biocerâmica + osso autógeno $(\mathrm{BC}+\mathrm{OA})$, biocerâmica + células osteoblásticas $(\mathrm{BC}+\mathrm{CO})$ e biocerâmica + células osteoblásticas + osso autógeno $(\mathrm{BC}+\mathrm{CO}+\mathrm{OA}) \mathbf{4 2}$ dias após a extração dentária. Teste estatístico ANOVA e Tukey. $(n=7) .{ }^{* *}$ significante a $1 \% .{ }^{*}$ significante a $5 \%$.

\begin{tabular}{|c|c|c|c|c|c|c|c|}
\hline \multicolumn{7}{|c|}{ Coágulo Sanguíneo - 42 dias } \\
\hline Controle & OA & Co & OA+Co & BC & BC+OA & BC+Co & BC+CO+OA \\
\hline 0 & 0,9 & 2,9 & 0,5 & 1,8 & 0,1 & 0,1 & 0 \\
\pm & \pm & \pm & \pm & \pm & \pm & \pm & \pm \\
1,29 & $1,39^{* *}$ & $1,04^{* *}$ & $2,07^{*}$ & $1,84^{* *}$ & 2,26 & 2,04 & 2,3 \\
\hline
\end{tabular}

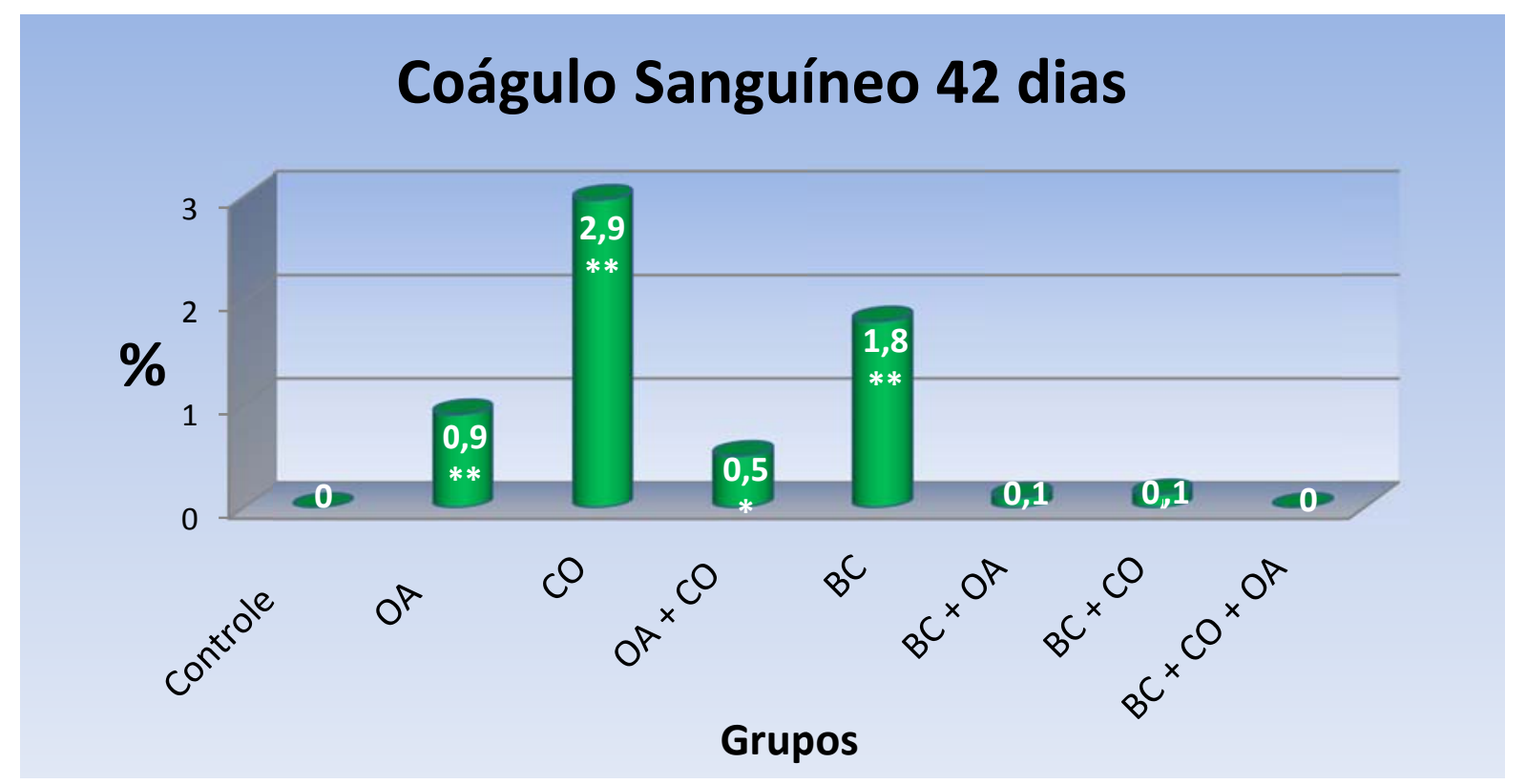

Figura 43: Média aritmética da fração de volume (\%) de coágulo sanguíneo no alvéolo dentário dos animais controle, osso autógeno (OA), células osteoblásticas $(\mathrm{CO})$, osso autógeno + células osteoblásticas $(\mathrm{OA}+\mathrm{CO})$, biocerâmica $(\mathrm{BC})$, biocerâmica + osso autógeno $(\mathrm{BC}+\mathrm{OA})$, biocerâmica + células osteoblásticas $(\mathrm{BC}+\mathrm{CO})$, e biocerâmica + células osteoblásticas + osso autógeno $(\mathrm{BC}+\mathrm{CO}+\mathrm{OA}), 42$ dias após a extração dentária. ${ }^{* *}$ significante a $1 \%$. * significante a $5 \%$. 
Tabela 24: Comparações múltiplas entre os diversos grupos estudados através do teste estatístico ANOVA e Tukey para a porcentagem de coágulo sanguíneo em 7 , 21 e 42 dias (significância descrita na tabela). C - controle; OA - osso autógeno; CO - células osteoblásticas; BC - biocerâmica.

\section{Coágulo Sanguíneo}

\begin{tabular}{|c|c|c|c|}
\hline Grupos & 7 dias & 21 dias & 42 dias \\
\hline $\mathrm{C} \times \mathrm{OA}$ & $1 \%$ & n.s. & n.s. \\
\hline $\mathrm{C} \times \mathrm{CO}$ & $1 \%$ & $1 \%$ & $1 \%$. \\
\hline $\mathrm{C} \times \mathrm{OACO}$ & $1 \%$ & n.s. & n.s. \\
\hline $\mathrm{C} \times \mathrm{BC}$ & $1 \%$ & $5 \%$ & $1 \%$ \\
\hline $\mathrm{C} \times \mathrm{BCOA}$ & n.s. & n.s. & n.s. \\
\hline $\mathrm{C} \times \mathrm{BCCO}$ & n.s. & n.s. & n.s. \\
\hline $\mathrm{C} \times \mathrm{BCCOOA}$ & n.s. & n.s. & n.s. \\
\hline $\mathrm{OA}$ x CO & n.s. & $1 \%$ & $1 \%$ \\
\hline OA x OACO & n.s. & n.s. & n.s. \\
\hline $\mathrm{OA}$ x BC & n.s. & n.s. & n.s. \\
\hline $\mathrm{OA} \times \mathrm{BCOA}$ & $5 \%$ & n.s. & n.s. \\
\hline OA x BCCO & $5 \%$ & n.s. & n.s. \\
\hline OA $x$ BCCOOA & $1 \%$ & n.s. & n.s. \\
\hline CO x OACO & n.s. & $1 \%$ & $1 \%$ \\
\hline $\mathrm{CO} \times \mathrm{BC}$ & $5 \%$ & n.s. & n.s. \\
\hline $\mathrm{CO} \times \mathrm{BCOA}$ & $5 \%$ & $1 \%$ & $1 \%$ \\
\hline $\mathrm{CO} \times \mathrm{BCCO}$ & $5 \%$ & $1 \%$ & $1 \%$ \\
\hline $\mathrm{CO} \times \mathrm{BCCOOA}$ & $1 \%$ & $5 \%$ & $1 \%$ \\
\hline OACO x BC & n.s. & $1 \%$ & $5 \%$ \\
\hline OACO $\times$ BCOA & $1 \%$ & n.s. & n.s. \\
\hline $\mathrm{OACO} \times \mathrm{BCCO}$ & $1 \%$ & n.s. & n.s. \\
\hline OACO x BCCOOA & $1 \%$ & $5 \%$ & n.s. \\
\hline $\mathrm{BC} \times \mathrm{BCOA}$ & $1 \%$ & $5 \%$ & $1 \%$. \\
\hline $\mathrm{BC} \times \mathrm{BCCO}$ & $1 \%$ & $5 \%$ & $1 \%$ \\
\hline $\mathrm{BC} \times \mathrm{BCCOOA}$ & $1 \%$ & n.s. & $1 \%$ \\
\hline $\mathrm{BCOA}$ x BCCO & n.s. & n.s. & n.s. \\
\hline BCOA $\times$ BCCOOA & $5 \%$ & n.s. & n.s. \\
\hline BCCO $\times$ BCCOOA & $5 \%$ & n.s. & n.s. \\
\hline
\end{tabular}

$\underline{\text { n.S. }- \text { não significante }}$ 


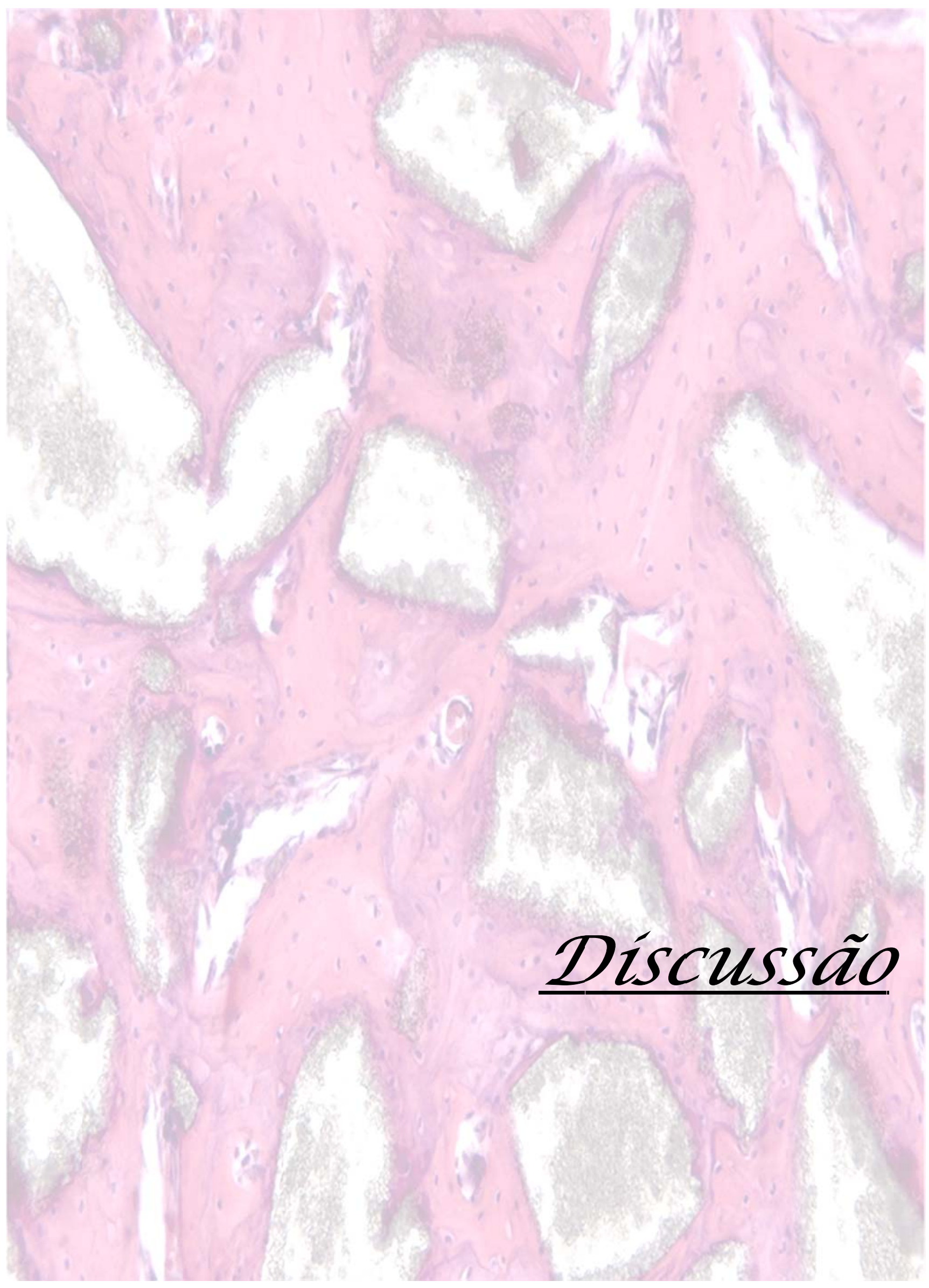




\section{Discussão}

\subsection{MODELO EXPERIMENTAL DE REPARAÇÃO ÓSSEA}

A reparação tecidual é um dos fenômenos mais interessantes que ocorrem nos organismos vivos. Deve-se ter em mente que este não é um processo isolado, mas faz parte de uma série complexa de eventos biológicos. A reparação dos tecidos biológicos é considerada uma fase da reação inflamatória, de vez que não pode ser separado dos fenômenos vasculares e celulares que ocorrem em resposta a uma agressão (Kummar et al., 2005).

O processo de reparação consiste em uma perfeita e coordenada cascata de eventos celulares e moleculares que interagem para que ocorra a repavimentação e a reconstituição do tecido. Tal evento é dinâmico envolvendo fenômenos bioquímicos e fisiológicos que se comportam de forma harmoniosa a fim de garantir a restauração tissular. Incluem diversos processos, como coagulação, inflamação, depósito de substâncias e síntese de matriz, a angiogênese, fibroplasia, a epitelização, a retração da lesão e remodelação (Mandelbaum, 2003).

O início da coagulação é imediato após o surgimento da ferida. Essa fase depende da atividade plaquetária e da cascata de coagulação. Ocorre uma complexa liberação de produtos. Substâncias vasoativas, proteínas adesivas, fatores de crescimento e proteases são liberadas e ditam o desencadeamento de outras fases. A formação do coágulo serve para cruzar a fibronectina, oferecendo uma matriz provisória, em que os fibroblastos, células endoteliais e queratinócitos possam ingressar na ferida. Intimamente ligada à fase anterior, a inflamação depende, além de inúmeros mediadores químicos, das células inflamatórias, como 
os leucócitos polimorfonucleares (PMN), macrófagos e linfócitos. Os PMN chegam no momento da injúria tissular e ficam por período que varia de três a cinco dias, são eles os responsáveis pela fagocitose das bactérias (Werner e Grose, 2003). O macrófago é a célula inflamatória mais importante dessa fase, permanece do terceiro ao décimo dia, fagocita bactérias, debrida corpos estranhos e direciona o desenvolvimento de tecido de granulação. Alta atividade dos macrófagos é observada após o trauma. Os linfócitos aparecem na ferida aproximadamente em uma semana, seu papel não é bem definido, porém sabe-se que, com suas linfocinas, tem importante influência sobre os macrófagos. Além das células inflamatórias e dos mediadores químicos, a fase inflamatória conta com o importante papel da fibronectina. Sintetizada por uma variedade de células como fibroblastos, queratinócitos e células endoteliais, ela adere, simultaneamente à fibrina, ao colágeno e a outros tipos de células, funcionando assim como cola para consolidar o coágulo de fibrina, as células e os componentes da matriz. Além de formar essa base para a matriz extracelular, tem propriedades quimiotáticas e promove a psonização e fagocitose de corpos estranhos e bactérias. Os mediadores mais frequentes são: Fator de Crescimento de Fibroblastos (FGF); Fatores de Crescimento Transformadores (TGF- $\beta$ e TGF- $\alpha$ ); Fator de Crescimento Derivado de Plaquetas (PDGF); Complementos plasma-ativados C3 e C5a (toxinas anafiláticas), eles conduzem a multiplicação das células endoteliais, produzindo novos vasos sanguíneos (angiogênese), duplicando células musculares lisas e sintetizando matriz. Muitos fatores que influem no processo de reparação tecidual são secretados pelos macrófagos, como TGFs, citocinas e interleucina-1 (IL-1), fator de necrose tumoral (TNF) e PDGF (Mandelbaum 2003; Werner e Grose, 2003). 
Na sequência final está a proliferação, que é o fechamento do processo com a presença do tecido de granulação, angiogênese, fibroplasia e formação da matriz, que no tecido ósseo finaliza com a formação do osteóide e mineralização (LamanoCarvalho et al., 1997).

O processo de reparação de feridas de extração dentária, ou processo de reparação alveolar, refere-se ao conjunto de reações teciduais desencadeadas no interior do alvéolo, em seguida à exodontia. Tem sido estudado detalhadamente, visto que dentre os procedimentos cirúrgicos, as exodontias ocupam posição de destaque nos consultórios odontológicos (Johansen, 1970).

O organismo tem como objetivo, frente a um traumatismo após a extração dentária, preencher com tecido ósseo o espaço deixado no alvéolo. Este fenômeno apresenta a mesma sequência das respostas reparativas observadas em outras regiões, com algumas particularidades locais (Carvalho e Okamoto, 1987).

A cicatrização de uma ferida de extração dentária, que é a ferida óssea mais comum na cavidade oral, é uma extensão única de tecido conjuntivo cicatricial, pois a formação de novo osso depende da deposição de cristais de hidroxiapatita ao longo das fibras colágenas em uma matriz de proteoglicanas chamada osteóide (Kurita et al., 1985). A mineralização do alvéolo dentário se dá a partir do terço apical em direção ao cervical e das paredes alveolares para o centro (Santos Pinto, 1964). O epitélio da mucosa gengival prolifera sobre o coágulo organizado e/ou sobre o tecido conjuntivo jovem, na tentativa de restabelecer a continuidade da cobertura epitelial do rebordo alveolar. A reparação alveolar se completa quando o alvéolo dentário apresentar-se preenchido por trabéculas ósseas espessas e espaços medulares diminutos e a crista alveolar remodelada (Carvalho e Okamoto, 1987). 
O modelo experimental por nós adotado nesta pesquisa utilizou o rato Wistar como animal de estudo pela facilidade de manejo durante o experimento, custo inferior e também por possuir um metabolismo ósseo mais acelerado em comparação com animais de porte maior como coelhos e cães, tendo como vantagem a obtenção de resultados em tempos menores e a conclusão do trabalho mais rápida.

O sítio analisado foi o alvéolo dentário pós-extração, por ser considerado um defeito ósseo que apresenta bastante semelhança aos eventos reparativos alveolares humanos, bem como em relação às particularidades teciduais encontradas na região oral e maxilofacial.

Já é bem documentado na literatura esta abordagem de análise do processo reparacional sobre influências tanto sistêmicas (Machado et al., 2010; Lacerda et al., 2010; Macedo et al., 2011; Teófilo et al., 2011; Aguirre et al., 2011; Macedo et al., 2012), quanto locais com o objetivo também de estudar a biocompatibilidade e a capacidade de biomateriais em substituir e promover uma melhor neoformação óssea (Calixto et al., 2007; Prata et al., 2007; Melo, 2007; Wu et al., 2008; Macedo et al., 2011; Reis-Filho et al., 2012).

Quanto aos achados histológicos e histométricos dos animais controle deste estudo, os mesmos estão de acordo com os dados relatados na literatura e também os encontrados pelo nosso grupo de pesquisa ao longo dos anos (Lamano-Carvalho et al., 1997; Lacerda et al., 2010; Macedo et al., 2011; Macedo et al., 2012). Sendo que para a maioria destes trabalhos a porcentagem de tecido ósseo neoformado no alvéolo dentário sem o uso de qualquer biomaterial ou interferência sistémica aos 7 dias variava de 30 a $38 \%$, de 54 a $62 \%$ aos 21 dias e de 66 a $78 \%$ aos 42 dias, o 
que possibilitou a realização de um estudo comparativo seguro entre os diversos materiais de substituição óssea utilizados nesta presente pesquisa.

\subsection{OSSO AUTÓGENO E REPARAÇÃO ÓSSEA}

A compreensão do processo de reparação no organismo é de grande importância na busca de materiais que possam interferir favorecendo a restauração tecidual de maneira rápida e adequada.

Sabendo da necessidade de um sítio ósseo anatomicamente favorável à instalação dos implantes osteointegrados de titânio, para a futura reabilitação implantossuportada, é que clínicos e pesquisadores buscam materiais que sejam capazes de diminuir o remodelamento/reabsorção óssea pós-extração, bem como reconstruir, de forma rápida e previsível, este tecido eventualmente perdido.

Segundo Hench e Wilson (1984), existem duas classes de implante endósseo: com ligação óssea e sem ligação óssea. Enquanto os metais como o titânio não tem ligação, materiais com cálcio e fosfato são denominados osteoligantes (Davies, 1998). A osteogênese associada a materiais utilizados como implante vem sendo estudada por vários autores. Os termos osteogênese à distância e osteogênese por contato foram primeiramente descritos por Osborn e Newesley (1980). Estes termos descrevem essencialmente dois fenômenos diferentes onde o osso se forma justaposto à superfície do implante: osteogênese à distância, onde o novo osso é formado na superfície do osso pré-existente no sítio peri-implante, culminando com o envolvimento do implante pelo tecido ósseo. $\mathrm{O}$ outro fenômeno é a osteogênese por contato, onde novo osso se forma primeiro na superfície do implante, após a colonização por uma população de células 
osteogênicas antes do início da formação de matriz óssea (Osborn e Newesley, 1980; Davies, 1998).

O restabelecimento do volume ósseo pode ser obtido através de diversos materiais de implante/enxerto. Segundo Ellis III (2001), o enxerto ideal deveria ter as características estruturais de um enxerto em bloco e o potencial osteogênico de um enxerto ósseo esponjoso medular em partículas, fornecendo altas concentrações de células osteogênicas.

O objetivo na utilização dos biomateriais é a combinação de uma reparação rápida com capacidade de ser reabsorvido durante a remodelação óssea (Langstaff et al., 2001) ou osseointegrado ao tecido.

Diversos materiais para implante, cada um com suas propriedades próprias, são utilizados na tentativa de acelerar a reparação óssea. Muitos destes materiais quando usados sozinhos apresentam efeitos limitados ou variáveis sobre a reparação óssea e, em alguns casos com desvantagens específicas. Por esta razão, combinações de materiais têm sido feitas a fim de encontrar uma associação que apresente maior eficiência na reparação óssea (Cochran et al., 2003).

O osso autógeno é, ainda, a referência padrão ouro devido as suas excelentes propriedades biológicas e ao seu grande potencial osteogênico, osteoindutor e osteocondutor (Minichetti et al., 2004; Jensen et al., 2006; Miyamoto et al., 2012; Schmitt et al., 2012).

Para um enxerto ser considerado favorável tornam-se necessárias algumas características ideais que o osso autógeno apresenta como um substituto ósseo, que são: livre de transmissão de doenças, biocompatibilidade, radiopacidade, microporosidade, estimular a indução óssea, reabsorver em período comparativo ao da formação óssea, ser substituído por tecido ósseo, fácil de ser obtido e 
manipulado, agir como matriz ou veículo para outros materiais e ter baixo custo (Gross, 1997).

Neste trabalho também se avaliou através da histologia e histometria a reparação óssea do defeito ósseo produzido pela extração dentária utilizando como implante/enxerto o osso autógeno provindo da calota craniana isoladamente, ou associado às células tronco e/ou biocerâmica.

O exame histológico dos alvéolos dos animais que receberam a implantação do osso autógeno isoladamente (grupo OA) mostrou um padrão normal de reparação, apresentando características similares aos da literatura, incluindo aqueles do nosso laboratório (Prata et al., 2007; Lacerda et al., 2009; Macedo et al., 2011). A análise mostrou que o material enxertado é biocompatível, não sofreu reação de corpo estranho, e foi progressivamente integrado ao osso alveolar no processo de reparação óssea (Figuras 12A e B; 15A, B, D e F; e 18A, B e F).

O osso autógeno provindo da calota craniana como material de transplante/enxerto é considerado um material com bons resultados clínicos e experimentais (Donovan et al., 1994; Crespi et al., 2007; Gutta et al., 2009; Bastos et al., 2012), pois segundo Ozaki e Buchman (1998) a sua origem embriológica, intramembranosa, é a mesma dos ossos da região oral e maxilofacial, o que favorece a integração do tecido ao leito receptor e a aposição de novo tecido ósseo quando comparado aos de origem endocondral.

Comparando enxertos de osso autógeno da calvária e da crista ilíaca para elevação do assoalho do seio maxilar em humanos, Crespi et al. (2007) observou que o enxerto obtido da calota craniana (origem intramembranosa) apresentou significantemente maior volume ósseo total e maior volume de osso vital comparado ao enxerto ósseo da crista ilíaca (origem endocondral). 
Sbordone et al., (2012a) também relata que os enxertos de ambas origens sofrem reabsorção ao longo do tempo, mas a maior parte dos de crista ilíaca utilizado nas reconstruções ósseas dos maxilares foram progressivamente reabsorvido ao longo dos anos.

Do mesmo modo, Deppe et al. (2012) analisando enxertos ósseos autógenos de origem intra e extraoral para a elevação de seios maxilares humanos verificou que o enxerto proveniente da crista ilíaca (endocondral) sofreu uma maior taxa de reabsorção comparado ao da sínfise mandibular (intramembranoso).

Nos períodos estudados, a análise histométrica dos alvéolos implantados com osso autógeno não mostrou diferenças estatisticamente significantes aos 7 e 21 dias, quando comparado aos animais do grupo controle (Tabelas 1, 2 e 3; Figuras 27, 28 e 29), o que tem semelhança com os resultados apresentados por Melo (2007), cuja metodologia foi semelhante à utilizada neste trabalho, e a pesquisa de Silva et al. (2012) utilizando gatos, onde diferenças também não foram encontradas em relação aos controles.

Dinato e Polido (2004), Misch (2006) descrevem com clareza o mecanismo de crescimento e reparação em um enxerto ósseo autógeno em que destaca 3 fases:

- As células transplantadas vivas, principalmente da porção esponjosa do enxerto, sobrevivem nos primeiros 3 ou 4 dias por meio da alimentação com o tecido vascular circunjacente. Entre 5 e 7 dias inicia-se o processo de angiogênese e revascularização. Estas células viáveis vão depositar uma matriz óssea desorganizada, sem sistema de Havers ou periosteal organizado. Este osso é chamado de Fase I, está associado ao número de células transplantadas e determina a quantidade de osso que se formará além da dimensão original. 
- À medida que as células transplantadas morrem, as células ósseas do tecido receptor seguem e remodelam o enxerto por meio da reabsorção do osso de Fase I, e o substituem por um osso mais organizado, com sistema periosteal e harvesiano. Este osso é conhecido como osso Fase II. Neste remodelamento, os osteoclastos reabsorvem a matriz inorgânica do enxerto original, liberando fatores de crescimento e proteínas indutoras do crescimento e diferenciação de células osteoprogenitoras (osteoindução).

- E por ultimo a matriz inorgânica de HA, que forma uma plataforma no enxerto autógeno, contribui para o efeito osteocondutor da formação óssea à medida que o osso novo se forma por meio da substituição. Este processo pode ser considerado como uma terceira fase da formação óssea pelo osso autógeno.

O tecido ósseo sofre remodelação contínua durante a vida através de um processo que foi descrito por Frost (1969). Em adultos, aproximadamente $25 \%$ do osso trabecular é reabsorvido e substituído todo ano (Monolagas e Jilka, 1995). Segundo Parfitt (1984), a remodelação trabecular óssea ocorre quando a reabsorção óssea é iniciada em uma superfície previamente quiescente; uma discreta unidade de osso é removida, e a lacuna resultante é preenchida imediatamente por novo osso. A fase de formação óssea é mediada por osteoblastos que substituem os osteoclastos na lacuna de reabsorção e teoricamente podem preenchê-la com menor, maior ou igual quantidade de tecido ósseo.

Ao analisar qualitativamente o osso autógeno contido no interior do alvéolo dentário aos 42 dias, puderam ser notados fragmentos com menores dimensões, bastante osteointegrados e com difícil distinção dos seus limites em relação ao tecido ósseo neoformado reparacional quando comparado aos períodos iniciais de estudo. Estas características demonstram que uma adequada remodelação deste 
material de enxerto está ocorrendo, cumprindo o papel descrito no parágrafo acima, onde o mesmo é progressivamente substituído por osso lamelar (Figuras 17, 18B e F).

Histometricamente, neste mesmo período (42 dias), observou-se a menor porcentagem de preenchimento ósseo no interior do alvéolo dentário dos animais enxertados com o osso autógeno (grupo OA), em comparação a todos os demais grupos do estudo (Tabela 3 e figura 29), estatisticamente significante a 1 e $5 \%$ (Tabela 4). Este achado provavelmente ocorreu devido ao grau de reabsorção do osso autógeno com o decorrer do processo reparacional, como relatado por Sbordone et al. (2012b). Esta facilidade em ser reabsorvido, por um lado libera maiores quantidades de BMPs para o meio, mas de outro diminui o volume do tecido ósseo enxertado na área. Sabendo dessa informação é que os clínicos devem estipular o período adequado para a reentrada nas áreas enxertadas com osso autógeno, pois um tempo curto não satisfaz os requisitos de maturidade e mineralização, e um tempo longo pode propiciar a perda volumétrica da área reconstruída (Khoury, 2011).

\subsection{BIOCERÂMICAS E REPARAÇÃO ÓSSEA}

Apesar das reconstruções ósseas utilizando osso autógeno apresentarem inúmeras vantagens quanto ao ganho efetivo de tecido ósseo, e este ainda ser considerado o padrão ouro, a sua obtenção leva a necessidade de um sítio cirúrgico extra ou intraoral adicional, levando a um maior grau de morbidade ao paciente (Miyamoto et al., 2012). 
Em sítios extraorais, como a crista ilíaca, Barone et al. (2011) demonstraram que de todos os pacientes, $99 \%$ relataram dor, $100 \%$ relataram desordens funcionais e $54 \%$ alguma mudança sensorial nesta área doadora. Em calvária, o pós-operatório parece ser melhor que o de crista, mas o risco de exposição da duramáter e injurias nervosas durante o procedimento existem (Touzet et al., 2011). Em áreas doadoras intraorais, $40,5 \%$ dos pacientes relatam distúrbios sensoriais temporários no mento e 16,2\% quando o ramo foi a área de eleição (Cordaro et al., 2011).

Baseado nestes achados e buscando uma diminuição da morbidade relacionada aos procedimentos reconstrutores ósseos, é que dentre muitos outros biomateriais, as biocerâmicas sintéticas têm sido uma alternativa nas cirurgias ósseas maxilofaciais e em implantodontia (Wakimoto et al., 2011; Mardas et al., 2011; Schmitt et al., 2012; Antunes et al., 2013).

A resposta do organismo à implantação tecidual de um biomaterial é complexa e dependente das características inerentes a cada material. O próprio processo de implantação envolve algum grau de agressão tecidual que induz a duas reações principais, a resposta inflamatória e o processo de reparo, cujo objetivo é restaurar a integridade e a homeostasia tecidual. No entanto, a duração e a intensidade destas reações são diretamente proporcionais à extensão do processo inflamatório. Deste modo, o sucesso da integração tecidual do biomaterial depende da sua capacidade de estimular respostas fisiológicas do processo de reparo e controlar reações indesejáveis da inflamação. O processo inflamatório normalmente é uma resposta protetora do organismo contra a invasão de componentes estranhos. Porém, a implantação de um biomaterial pode resultar na persistência do processo inflamatório a fim de eliminar o material estranho/irritativo, desencadeando efeitos 
negativos que levam a extensos danos teciduais. A irritabilidade ou a incompatibilidade de um material é decorrente de suas características físicoquímicas, do tipo de adsorção proteica e da capacidade de ativar as células inflamatórias, os quais podem ser melhorados durante a manufatura e processamento do material. Assim a magnitude e a duração do processo inflamatório estão diretamente ligadas a biocompatibilidade do biomaterial (Cestari et al., 2011).

O processo de enxertia/implantação de um substituto ósseo leva inicialmente a uma reação inflamatória aguda que pode evoluir para uma resposta inflamatória crônica e/ou a formação do tecido de granulação. Em seguida a fim de atingir o equilíbrio, o organismo pode lançar mão de 4 tipos de resoluções que dependem da biocompatibilidade do material utilizado, extensão da lesão, local de implantação, estabilidade do material implantado e das condições clínicas do paciente. Assim segundo Cestari et al., (2011) podemos ter a:

1- Extrusão do material devido à manutenção e a extensão do processo inflamatório com o desenvolvimento de uma reação tipo corpo estranho persistente com grande dano tecidual a fim de expulsar ou destruir o agente agressor.

2- Reabsorção do material e a substituição por tecido conjuntivo ou tecido nativo (osso no caso do tecido ósseo).

3- Integração do material, com a formação na sua interface de um tecido adjacente semelhante ao original.

4- Encapsulação do material por tecido conjuntivo fibroso. Neste caso os macrófagos e/ou células gigantes multinucleadas tipo corpo estranho participam ativamente na produção de fatores pró-fibróticos ao redor do material, estimulando a fibrogênese colágena progressiva. 
A análise qualitativa dos grupos que receberam a implantação da biocerâmica de fosfato de cálcio bifásica demonstrou que a mesma apresenta biocompatibilidade, pois não houve a persistência do processo inflamatório agudo nos períodos tardios de análise (21 e 42 dias), nem a presença de células gigantes multinucleadas na periferia do material. O mesmo não sofreu extrusão ou encapsulação fibrosa (Figura 15C, D, E e F; Figura 18C, D, E e F), e sim o processo evoluiu para a integração com o osso recém sintetizado seguido pela sua lenta reabsorção e posterior aposição óssea .

Biocompatibilidade é a habilidade de um material agir com adequada resposta ao organismo, em uma aplicação específica, sem gerar efeitos locais ou sistêmicos no hospedeiro, proporcionando uma resposta benéfica, em níveis estruturais distintos: células, tecidos e órgãos, sendo a mais adequada possível para aquela situação específica (Pedrosa et al., 2011).

A adequada compatibilidade tecidual da biocerâmica em questão está de acordo com dados apresentados em relação a diversos procedimentos de reconstruções ósseas bucomaxilofaciais, como o uso da mesma para levantamento de seios maxilares humanos (Cordaro et al., 2008; Frenken et al., 2010; Lindgren et al., 2012; Schimitt et al., 2012), para regeneração óssea guiada ao redor de implantes (Zambom et al., 2011; Antunes et al., 2013) e manutenção/regeneração do rebordo alveolar pós-extração (Mardas et al., 2010, 2011; Wakimoto et al., 2011; Patel et al., 2012).

A interação do material implantado com o hospedeiro inicia-se em nano segundos após o primeiro contato com os componentes teciduais. Nesse processo ocorre a adsorção de proteínas plasmáticas e de outras macromoléculas presentes no local da injúria como, o fibrinogênio, fibronectina, vitronectina, imunoglobulina, 
fator de Von Willebrand e os fatores do sistema complemento ao biomaterial. Mais de 200 tipos de proteínas contidas no plasma competem pela superfície do material num complexo processo de adsorção, desadsorção e rearranjo na superfície até atingirem um equilíbrio na interface que é conhecido como efeito de Vroman. A deposição das proteínas sanguíneas na superfície do material é descrito como a formação da matriz provisória. A presença de mitógenos, citocinas, quimiocinas, fatores de crescimento, e outros bioativos nesta matriz, formam um ambiente rico em substâncias de ativação e inibição capazes de modular a atividade celular. A estrutura e a composição desta camada protéica são principalmente governadas pelas propriedades físico-químicas da superfície do biomaterial, o que irá ditar em grande parte a capacidade de adesão celular ao material implantado (Cestari et al., 2011).

A análise qualitativa da capacidade de osteointegração da biocerâmica nos diversos grupos de animais implantada (Grupos $\mathrm{BC}, \mathrm{BC}+\mathrm{OA}, \mathrm{BC}+\mathrm{CO}, \mathrm{BC}+\mathrm{CO}+\mathrm{OA}$ ) demonstrou que em todos os períodos analisados houve íntimo contato com os tecidos circunjacentes. No período de 7 dias parte da superfície da biocerâmica estava em contato com um tecido conjuntivo contendo fibras colágenas aderidas a mesma, sem reações inflamatórias agudas, e outras áreas já possuíam tecido ósseo recém sintetizado em íntimo contato com este biomaterial (Figura 12C).

Estudos prévios têm mostrado que a bioatividade das cerâmicas de fosfato de cálcio varia de acordo com a composição química de sua fase, temperatura de sinterização e estrutura superficial (Yuan et al., 2001; Habibovic et al., 2006; Fan et al., 2006), refletindo na capacidade de adsorção de algumas proteínas características e consequentemente ditando o comportamento biológico. 
A porosidade das cerâmicas bifásicas também tem um importante papel nesta atração/ligação de proteínas e posteriormente ao recrutamento das células ósseas a sua superfície. Zhu et al. (2010) demonstraram que partículas com microporosidades acima de $20 \mu \mathrm{m}$ podem adsorver mais fibrinogênio, insulina e colágeno tipo 1 comparado a outras características superficiais.

O fibrinogênio depois de ativado se transforma em fibrina e consequentemente consolida a formação do coágulo sanguíneo, tecido este de suma importância para os eventos iniciais da reparação óssea, que por sua vez será gradualmente substituído por tecido conjuntivo (Kummar et al., 2005). Talvez o adequado comportamento do tecido conjuntivo, com boa adesão das fibras colágenas a superfície da biocerâmica, como evidenciado aos 7 dias pela microscopia de luz (Figura 12C) e aos 21 dias pela microscopia eletrônica de varredura (Figura 21A e B) possa ter ocorrido devido a facilidade dos poros deste material em atrair o fibrinogênio e assim desencadear uma rápida formação do coágulo sanguíneo, oferecendo assim um arcabouço favorável ao estabelecimento dos fibroblastos, que aliados ao maior aporte da insulina, refletiu na alta atividade sintética desta célula. Outro fator coadjuvante neste processo possa ter sido a maior capacidade de adsorção do colágeno tipo I sintetizado neste microambiente (Zhu et al., 2010) e consequentemente maior facilidade em constituir as fibras colágenas.

Os fosfatos de cálcio têm uma composição química semelhante à fase inorgânica do tecido ósseo humano e têm sido extensivamente estudado por um longo tempo no campo dos biomateriais. Desde que a osteoindução dos fosfatos de cálcio foi relatada em 1991 (Zhang et al., 1991; Ripamonti, 1991) os cientistas têm explorado este mecanismo sem ainda entende-lo completamente. 
A porosidade adequada é necessária para o desenvolvimento da osteoindução nas cerâmicas de fosfato de cálcio (Yuan et al., 1998), pois uma estrutura densa não poderia induzir a formação óssea ectópica (Misiek et al., 1984). Além disso, a composição bifásica consistindo de hidroxiapatita (HA) e fosfato tricálcio- $\beta$ (TCP- $\beta$ ) apresenta melhores características osteoindutoras que as de fase única (Yuan et al., 2002). Vários fatores angiogênicos e de crescimento ósseo, especialmente os da superfamília dos fatores de crescimento transformador incluindo a proteína óssea morfogenética-2 (BMP-2) e o fator de crescimento transformador- $\beta 1$ (TGF- $\beta 1$ ) participam do processo de formação e remodelação do tecido ósseo (Bootheekul e Mooney, 2003), deste modo a capacidade de concentração de vários fatores de crescimento sob condições fisiológicas nestes biomateriais deva ser necessário para a adequada capacidade osteoindutora dos fosfatos de cálcio (Zhang et al., 2000).

Dois diferentes sítios de ligação são conhecidos nos fosfatos de cálcio, chamados sítios $\mathrm{C}$ positivos e sítios $\mathrm{P}$ negativos na superfície do cristal (Ohta et al., 2001), e por isso as diferentes estruturas destas biocerâmicas têm habilidades distintas de ligação à proteínas, pois as estruturas porosas podem promover a ligação de um maior número de proteínas do que a estrutura densa, devido a uma maior área de superfície que fornece múltiplos sítios de ligações proteicas.

Qualitativamente tanto aos sete, mas principalmente aos 21 e 42 dias, pode ser notada uma íntima união entre a biocerâmica utilizada nesta pesquisa e o tecido ósseo neoformado sem a interposição de tecido mole entre os mesmos (Figura 15C, D, E e F; Figura 18C, D, E e F). Tal característica está de acordo com os trabalhos de Cordaro et al. (2008); de Friedmann et al. (2009) e de Frenken et al. (2010), que relatam uma relação de bastante proximidade e ligação entre o tecido ósseo 
neoformado e as partículas remanescentes deste mesmo material de substituição óssea.

Na busca de uma análise mais detalhada e avaliando também a topografia tanto da biocerâmica quanto do osso neoformado em aumentos que chegaram a 10.000 vezes, foi possível também confirmar através da MEV este bom comportamento do biomaterial (Figuras 22, 23, 24 e 25), ou seja, justaposição biomaterial/osso.

A análise realizada pela MEV foi qualitativa, ou seja, pela observação de como se encontrava a interface da cerâmica de fosfato de cálcio bifásica com o tecido ósseo neoformado. Os resultados dos quais obtivemos estão de acordo com os relatados por Kitsugi et al. (1995) e Fujita et al. (2003b), no qual estes pesquisadores também puderam observar, através deste mesmo método, a ligação direta entre as diversas biocerâmicas por eles estudadas e a matriz osteóide recém sintetizada.

Esta ligação entre os grânulos da biocerâmica implantada no alvéolo dentário dos animais e o tecido ósseo possivelmente ocorreu devido a algumas características peculiares a este biomaterial como as descritas abaixo.

Em primeiro lugar o componente inorgânico do tecido ósseo é composto na sua grande maioria por cristais de hidroxiapatita, e a estrutura química da biocerâmica é também de hidroxiapatita/fosfato tricálcio- $\beta$ numa proporção de 60:40 respectivamente. Esta semelhança molecular possa ter facilitado a ligação entre os íons cálcio e fosfato tanto dos cristais da biocerâmica quanto dos componentes inorgânicos das trabéculas ósseas (Daculsi et al., 2003), mediados pelas proteínas ósseas e fatores de crescimento adsorvidos á superfície do material nas fases iniciais da síntese osteoblástica. 
Associado a esta ligação química, em segundo lugar, uma adesão micromecânica possa ter ocorrido, pois a alta porosidade desta biocerâmica, aliado as irregularidades superficiais e os poros interconectantes (Figuras 19A, B e C), provavelmente tenha favorecido a formação de regiões retentivas em que a matriz óssea foi depositada (Figura 12F e 18E).

Em terceiro, pela possível característica angiogênica e osteoindutora deste biomaterial, já que a mesma possui porosidade de $90 \%$, e consequentemente uma grande área superficial com sítios viáveis de ligação. Desta forma, talvez uma maior adsorção à sua superfície de proteínas relacionadas à neoformação vascular como o fator de crescimento vascular e endotelial (VEGF) (Boëck-Neto et al., 2009) possa ter proporcionado a formação de uma suficiente rede capilar com a possibilidade de promover maiores quantidades de nutrientes às células. Também maior concentração de proteínas responsáveis pela neoformação óssea, como o fator de crescimento transformador $\beta 1$ (TGF- $\beta 1$ ) (Zhu et al., 2010), tenha possibilitado um maior recrutamento e diferenciação de células osteoprogenitoras em osteoblastos para a região peri-implante, assim como relatado por Li et al. (2011) em um trabalho in vitro, culminando dessa forma com uma sólida deposição óssea nos arredores e nas porosidades deste biomaterial. Portanto, sabendo que a neoformação óssea é estritamente dependente da neoangiogênese (para revisão ver Das e Botchwey, 2011), uma coordenada e integrada sequência de eventos inter-relacionados possa ter colaborado para o resultado positivo demonstrado neste trabalho.

Por último o aumento da capacidade de adsorção do colágeno tipo I (Zhu et al., 2010) às partículas, pode ter favorecido a adesão e formação da trama fibrilar colágena à superfície da biocerâmica como evidenciado na figura 21A e B. Esta malha possivelmente melhorou a capacidade de aprisionamento e estabelecimento 
das células ósseas recrutadas para esta área pelos mediadores acima citados, facilitando assim a deposição da matriz osteóide.

Estas características, segundo os dados relatados na literatura e citados acima podem ter promovido o bom comportamento biológico osteointegrador deste biomaterial no defeito ósseo.

A análise quantitativa (histométrica) aos sete dias (Tabela 1 e Figura 27) dos animais que receberam a biocerâmica isoladamente (Grupo BC) demostrou maior valor percentual de preenchimento ósseo quando comparado aos grupos que não receberam este biomaterial (Grupos controle, OA, CO e OA+CO). Esta diferença não apresentou significância estatística apenas quando comparada ao grupo CO, nos demais tal característica foi observada (Tabela 4).

Acreditamos que esta maior porcentagem em relação aos grupos que não receberam a biocerâmica foi devido à presença do material no interior do alvéolo, pois tanto o tecido ósseo neoformado (tecido vital) quanto à biocerâmica foram contabilizados como "preenchimento ósseo". Esta abordagem histométrica quanto ao percentual de biomaterial e tecido ósseo neoformado somados segue o modelo de análise também utilizado por Cordaro et al. (2008), quando da avaliação de seios maxilares humanos, na qual os autores também realizaram esta somatória, mas utilizaram o termo osso mineralizado para estes dois componentes teciduais, e tecido mole para os demais tecidos encontrados na área enxertada.

Além das possíveis propriedades osteoindutoras das biocerâmicas de fosfato de cálcio (Farahpour et al., 2012) já relatadas acima, em especial as bifásicas, vários trabalhos têm demonstrado o bom comportamento osteocondutor das mesmas (Cordaro et al., 2008; Friedmann et al., 2009; Frenken et al., 2010; Farahpour et al., 
2012). Esta característica está relacionada principalmente á proporção das fases da biocerâmica e as dimensões dos poros contidos neste material.

Os poros nos materiais a base de fosfato de cálcio são necessários para a formação óssea, pois eles permitem a migração e proliferação dos osteoblastos e células mesenquimais, bem como da vascularização. Em adição, uma superfície porosa melhora a interligação entre o biomaterial implantado e o ambiente ósseo circunjacente, promovendo grande estabilidade mecânica nessa crítica interface (Karageorgiou e Kaplan, 2005).

Os poros podem ser divididos segundo a sua dimensão em dois diferentes grupos: microporos $(<5 \mu \mathrm{m})$ e macroporos (> $100 \mu \mathrm{m})$ (Blokhuis et al., 2000; Karageorgiou e Kaplan, 2005). Além das propriedades relacionadas à osteoindução, as microporosidades têm um importante papel na capacidade de bioreabsorção do material, e as macroporosidades na osteocondutividade (LeGeros et al., 2002; LeGeros et al., 2008). Para um substituto ósseo, a mínima dimensão recomendada é de $100 \mu \mathrm{m}$ para as macroporosidades (Hulbert et al., 1970), mas estudos subsequentes têm mostrado melhor osteogênese para substitutos com poros maiores que 300 m (Tsuruga et al., 1997; Kuboki et al., 2002; Karageorgiou e Kaplan, 2005). Poros menores $(75-100 \mu \mathrm{m})$ resultam na formação de um tecido osteóide não mineralizado ou a penetração de tecido fibroso (10-44 $\mu \mathrm{m}$ e 44-75 $\mu \mathrm{m})$ (Hulbert et al., 1970; Feng et al., 2011), no entanto alguns estudos relatam que o diâmetro de 100 um não seria o tamanho crítico para a neoformação óssea (Itala et al., 2001). Relativamente, poros maiores favorecem a osteogênese direta, desde que propiciem a vascularização e alta oxigenação, enquanto poros de menor dimensão resultam na ossificação osteocondral. Assim o tipo de crescimento ósseo dentro das porosidades da biocerâmica depende da característica do material e da 
geometria dos poros (Jin et al., 2000; Kuboki et al., 2002) (Para revisão ver Hannink e Arts, 2011).

A cerâmica de fosfato de cálcio bifásica utilizada nesta pesquisa é completamente sintética contendo $90 \%$ de porosidade. Os poros presentes neste biomaterial possuem diâmetro de 100 a 500 um (Dietze et al., 2006) (Figura 19), o que está de acordo com as informações contidas no parágrafo acima.

O uso do Straumann ${ }^{\circledR}$ BoneCeramic isolado (grupo BC) no interior do alvéolo dentário pós-extração revelou, a partir da análise histométrica aos 21 dias, um grau de preenchimento ósseo sem diferenças estatisticamente significante em relação aos grupos controle, $\mathrm{OA}, \mathrm{CO}$ e $\mathrm{OA}+\mathrm{CO}$ (Tabela 2 e figura 28).

Estes achados estão de acordo com os relatado por Cordaro et al. (2008), Friedmann et al. (2009), Schimmit et al. (2012), que demonstraram percentuais semelhantes de preenchimento ósseo em seios maxilares humanos com o uso desta biocerâmica em comparação com outros materiais substitutos ósseos, dentre estes os xenógenos (BioOss ${ }^{\circledR}$ - Geistlich) e heterógenos (Puros ${ }^{\circledR}$ - Zimmer), materiais estes também de ampla utilização nos procedimentos reconstrutores em implantodontia. Mardas et al. (2011) também relataram em um estudo clínico controlado randomizado de preservação óssea alveolar pós-extração com a utilização do Straumann ${ }^{\circledR}$ BoneCeramic e do BioOss ${ }^{\circledR}$, no qual dos 27 pacientes que compuseram a amostra não foi observada diferenças no volume de tecido ósseo/biomaterial com o uso destes implantes/enxertos.

Aos 42 dias, também não foi observada diferenças estatisticamente significante do grupo BC em relação ao controle, células osteoblásticas (CO), e osso autógeno + células osteoblásticas $(\mathrm{OA}+\mathrm{CO})$. Único grupo que obteve resultado inferior ao biocerâmica foi onde o osso autógeno foi implantado isoladamente nos 
animais (Gurpo OA) (Tabela 3 e Figura 29). Talvez esta diferença tenha ocorrido pela capacidade de reabsorção do osso autógeno mais rápida do que a da biocerâmica, o que vai de encontro com o trabalho de Fellah et al. (2008), cuja conclusão revela que os substitutos ósseos sintéticos com grau de reabsorção controlado podem promover, ao longo do tempo, uma maior estabilidade volumétrica ao osso recém sintetizado, especialmente em sítios pós-extração (Araújo e Lindhe, 2011).

O grupo de animais implantados com a biocerâmica e os fragmentos de osso autógeno da calota craniana associados (Grupo BC+OA) apresentaram aos 7 dias, valores maiores que todos os grupos estudados, exceto o grupo $\mathrm{BC}+\mathrm{CO}+\mathrm{OA}$ (Tabela 1 e Figura 27). Diferenças estatisticamente significante a $5 \%$ foram encontradas para todos os demais tratamentos executados exceto para os animais que receberam $\mathrm{BC}+\mathrm{CO}$ e $\mathrm{BC}+\mathrm{CO}+\mathrm{AO}$ (Tabela 4).

A análise histométrica realizada aos 21 dias dos animais deste mesmo grupo $(B C+O A)$ revelou um percentual de preenchimento ósseo do alvéolo dentário da ordem de 65,6\% (Tabela 2 e Figura 28), número este maior e com significância estatística quando comparado aos grupos controle, OA, CO, OA+CO e BC (Tabela 4). Estatisticamente não foi notada diferença entre este grupo e os dois últimos $(\mathrm{BC}+\mathrm{CO}$ e $\mathrm{BC}+\mathrm{CO}+\mathrm{OA})$.

No último período de análise (42 dias), a taxa de preenchimento ósseo dos animais do grupo $\mathrm{BC}+\mathrm{OA}$ foi maior que o de todos os demais grupos exceto pelo valor do grupo $\mathrm{BC}+\mathrm{CO}+\mathrm{OA}$ (Tabela 3 e Figura 29), diferença esta estatisticamente significante quando comparada aos grupos $\mathrm{OA}, \mathrm{CO}, \mathrm{OA}+\mathrm{CO}$, e BC (Tabela 4).

Este aumento no percentual de preenchimento ósseo para o grupo relatado acima $(B C+O A)$ provavelmente ocorreu devido às partículas de osso autógeno 
implantadas, na qual foram mensuradas juntamente com a biocerâmica. Associado a este fator, é conhecido o poder osteogênico, osteocondutor e osteoindutor deste biomaterial, que pode levar consigo células viáveis, servir como um ótimo meio de condução da formação óssea e à medida que a sua reabsorção ocorre, a liberação das BMPs para o meio é relatada. Assim estas características do osso autógeno agindo como coadjuvante às propriedades osteocondutoras e possivelmente osteoindutoras da biocerâmica, levaram então a uma deposição óssea mais acentuada.

A principal ideia biomédica por trás das formulações bifásicas, trifásicas e multifásicas das biocerâmicas de ortofosfato de cálcio é conseguir um equilíbrio entre as fases mais estáveis e as mais solúveis de tal forma que as propriedades mais importantes (nível necessário de bioatividade, bioreabsorção, osteocondutividade e osteoindutividade) de tais formulações possam ser ajustadas alterando a composição e as proporções entre as fases (Daculsi, 1998; Lobo e Arinzeh, 2010).

Segundo a Wikipédia, a enciclopédia livre, nas ciências físicas uma fase é uma região do espaço ao longo do qual todas as propriedades físicas e químicas de um material são essencialmente uniformes. Exemplos de tais propriedades incluem densidade, índice de refração, a composição química, estrutura cristalina, etc. Uma fase é também uma região de um material que seja quimicamente uniforme e fisicamente distinto, o que pode ser mecanicamente separável.

In vivo a biodegradabilidade das cerâmicas de fosfato de cálcio pode ser conseguida por dissolução ou mediada por células (Hannink e Arts, 2011).

A população das células responsáveis pela reabsorção das mesmas consiste principalmente de células multinucleadas e osteoclastos (Yamada et al., 1997), no 
entanto os macrófagos podem também estar envolvidos na fagocitose (Gisep et al., 2003). A velocidade de biodegradabilidade e o tipo de célula envolvida no processo de reabsorção são determinados pelas clássicas propriedades do material biocerâmico como, relação $\mathrm{Ca} / \mathrm{P}$, cristalinidade, tamanho da partícula, área de superfície e porosidade, bem como pelas características do ambiente biológico local, como pH, presença de células e quantidade de água (LeGeros, 2002).

Além das atividades reabsortivas relacionadas ao conteúdo celular, a solubilidade dos compostos cerâmicos também tem grande influência neste quesito (Hannink e Arts, 2011). A solubilidade do fosfato tricálcio (TCP) em água é superior a da hidroxiapatita (HA) sob as mesmas condições, logo, este tipo de cerâmica começou a ser utilizada em associação a HA em sistemas bifásicos para aumentar a solubilidade das cerâmicas em meio biológico, consequentemente, sua reabsorção pelo corpo humano. Isso é interessante quando se objetiva a regeneração/substituição controlada do material implantado pelo tecido novo. Apesar do grande número de enxertos comerciais usando sistemas multifásicos, a concentração ideal de TCP requerida para se equilibrar a taxa de degradação do material com a taxa de formação do novo tecido não foi bem estabelecida. Provavelmente, esse valor deve variar de acordo com a região óssea a ser reconstruída, a idade do paciente e com o tamanhão da lesão, tornado difícil qualquer tentativa de avaliação mais precisa (Santos e Barreira-Pinto, 2011).

A análise quantitativa da porcentagem volumétrica de biocerâmica, ao longo do tempo, implantada no alvéolo dentário revelou certo grau de reabsorção em todos os animais (grupos $\mathrm{BC}, \mathrm{BC}+\mathrm{OA}, \mathrm{BC}+\mathrm{CO}, \mathrm{BC}+\mathrm{CO}+\mathrm{OA}$ ) onde a mesma foi utilizada (Tabela 10 e Figura 35). A comparação entre estes grupos para cada período em 
questão (7, 21 e 42 dias) não revelou diferenças estatisticamente significantes em relação ao valor numérico percentual deste biomaterial (Tabela 14).

A avaliação isolada de cada grupo demonstrou o mesmo padrão de reabsorção de acordo com a progressão do processo reparacional (Tabelas 5, 6, 7 e 8; Figuras 30, 31, 32 e 33), na qual diferenças estatisticamente significantes a $1 \%$ e $5 \%$, quanto a redução volumétrica, foram encontradas apenas entre os períodos de 7 e 42 dias (Tabela 16).

O valor da média de biocerâmica mensurada no interior do alvéolo dos animais dos 4 grupos em questão ( $B C, B C+O A, B C+C O$ e $B C+C O+O A)$ foi de $44,29 \%$ aos 7 dias, caindo para $41,93 \%$ aos 21 dias, e para $36,9 \%$ no $42^{\circ}$ dia, resultando em uma taxa média de reabsorção da mesma de $7,39 \%$ durante o período experimental.

Paralelo à reabsorção dos grânulos da biocerâmica e do tecido mole (tecido conjuntivo + coágulo sanguíneo) ocorreu a deposição de novo tecido ósseo (tecido ósseo vital) no interior do alvéolo dentário (Tabelas 5, 6, 7 e 8; Figuras 30, 31, 32 e 33).

Provavelmente esta reabsorção e consequente diminuição no percentual volumétrico de biocerâmica no interior do alvéolo de 7 para 42 dias ocorreu pela dissolução/reabsorção em maior grau do fosfato tricálcio- $\beta$ em relação a hidroxiapatita, já que a solubilidade destes a $25^{\circ} \mathrm{C}$ é de 28,9 e $116,8-\log \mathrm{K}_{\mathrm{ps}}$ respectivamente. Sabe-se também que a dissolução da hidroxiapatita é mais lenta, e como o período máximo por nós analisado foi de 42 dias, acreditamos que não houve tempo hábil para que a mesma pudesse ser reabsorvida e substituída por novo osso, pois como relatado por Daculsi et al. (1999), apenas 50\% das partículas 
de HA/ß-TCP (proporção 60/40) são reabsorvidas e substituídas por osso lamelar após 1 ano.

O objetivo da utilização das biocerâmicas de fosfato de cálcio bifásicas é que um dos componentes, o menos solúvel (hidroxiapatita) possa fornecer resistência mecânica à área reconstruída enquanto o mais solúvel (fosfato tricálcio- $\beta$ ) à medida que vai sendo reabsorvido deixe lacunas osteocondutoras propícias a neoformação óssea (Daculsi et al., 1999).

Uma perfeita e coordenada atividade cronológica de reabsorção do biomaterial simultaneamente á deposição de nova matriz óssea é essencial para o sucesso do processo de reconstrução dos defeitos ósseos. O material de enxerto ideal deve, ao final do processo reparador, ser completamente substituído por um novo tecido ósseo que contenha células viáveis à remodelação e manutenção óssea resultando em uma adequada capacidade de suportar os esforços funcionais recebidos ao longo da vida (Figura 44A), ao passo que estas características são prejudicadas em um material de enxertia que não sofre reabsorção (Figura 44B). Já nos materiais onde o grau de reabsorção é exageradamente rápido, como nas biocerâmicas com alta dissolução, pode ser encontrado a presença de um espaço vazio esperando pela deposição de uma nova matriz osteóide (Figura 44C). 


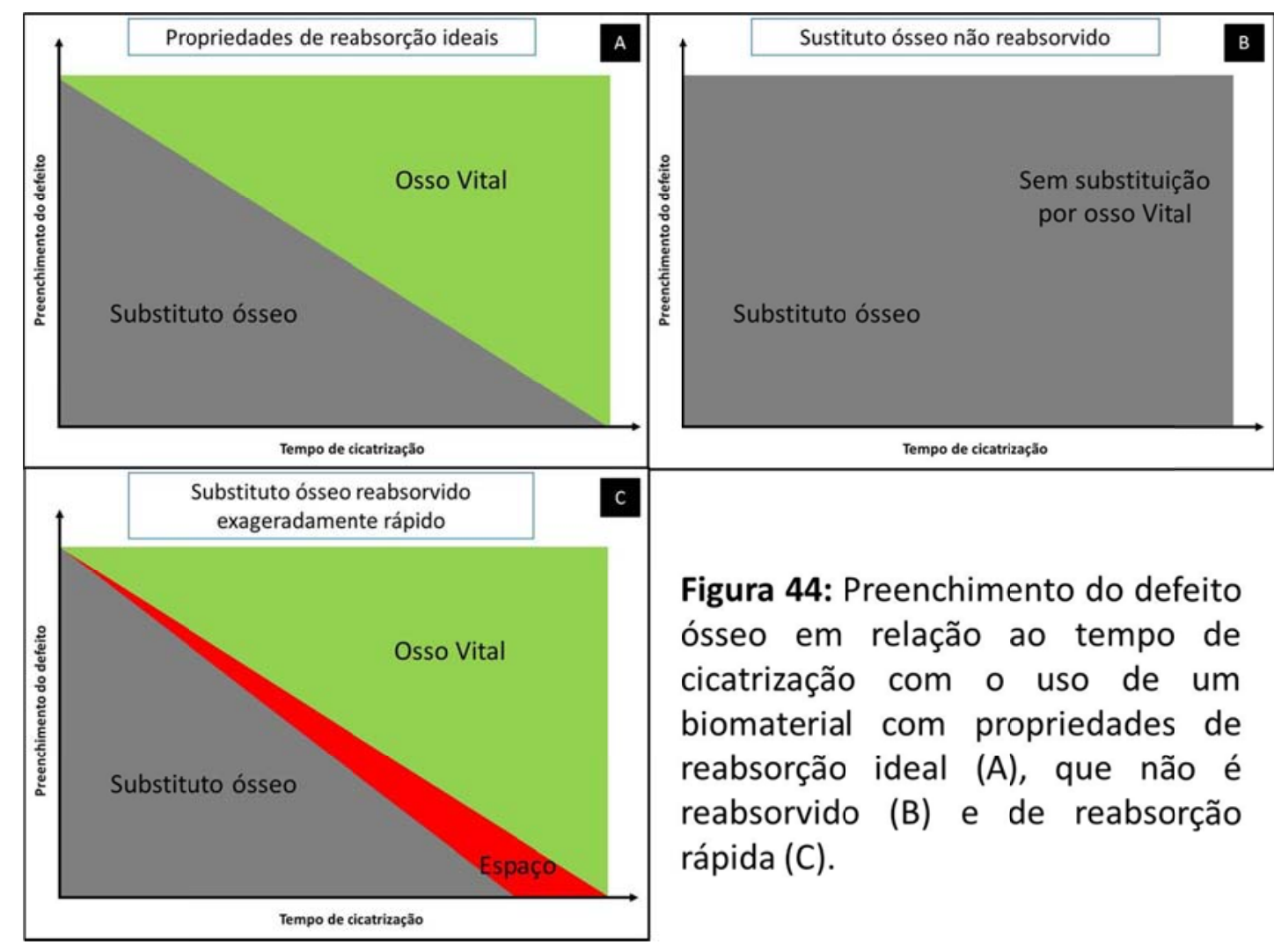

Vários trabalhos demonstram que a proporção hidroxiapatita/ $\beta$-TCP de 60/40 favorece o processo de neoformação óssea pela capacidade de aumentar as lacunas osteocondutoras através da dissolução progressiva dos componentes de sua fase (Cordaro et al., 2008; Friedmann et al., 2009).

A reabsorção controlada do material biocerâmico por nós estudado provavelmente favoreceu a deposição de um novo osso vital, já que aos 42 dias um tecido ósseo com boa densidade e compactação pode ser observado nos arredores do biomaterial (Figura 18C, D, E e F). Esta característica possa ter ocorrido devido a gradual dissolução do $\beta$-TCP e a consequente liberação de cálcio e fosfato neste ambiente, o que permitiu uma deposição óssea e mineralização mais efetiva nas microlacunas deixadas após a reabsorção de parte do material (Wiltfang et al., 2002; Daculsi et al., 2003, LeGeros et al., 2003). 
Sabendo que qualitativamente a biocerâmica de fosfato de cálcio bifásica em questão estava intimamente aderida/imbricada às trabéculas ósseas neoformadas, promovendo bom desempenho funcional, e que a mesma possui taxas de degradação compatível com o processo de reestruturação do tecido ósseo, é de se esperar que com o passar do tempo a remodelação óssea intra-alveolar substituirá toda a biocerâmica implantada por osso vital.

\subsection{CÉLULAS TRONCO E REPARAÇÃO ÓSSEA}

A medicina regenerativa com o uso de células tronco tem sido uma grande saída para o tratamento de defeitos ósseos (Vacanti e Bonassar, 1999; Ohgushi e Caplan, 1999). Células tronco mesenquimais podem facilmente ser expandidas para um grande número de células e quando utilizadas adequadamente podem melhorar a capacidade reparadora e cicatrizadora óssea (Hernigou et al., 2005; Lacerda et al., 2009; Macedo et al., 2011). A engenharia de tecidos tem sido proposta como uma alternativa para as tradicionais técnicas de reparação óssea (Zhang et al., 2012). O princípio geral da engenharia tecidual envolve associação de células a um suporte natural ou sintético, visando à produção tridimensional de um arcabouço contendo o material celular (Hasegawa et al., 2010).

Com a intenção de aumentar o número de células precursoras osteogênicas a serem adicionadas nos alvéolos dentários, realizamos a retirada da medula óssea femoral conforme método descrito por Maniatopoulos et al. (1988), seguido pela expansão destas células osteoprogenitoras e diferenciação das mesmas em osteoblastos (Rosa et al., 2003). Com esta técnica, obtivemos uma concentração de células nucleadas osteoprogenitoras já diferenciadas em osteoblastos maior que em 
um centrifugado osteogênico de medula, e maior que o aspirado medular na sua forma original. Ainda por meio do teste de viabilidade celular, confirmamos que estas células permaneceram viáveis após a expansão, excluindo a possibilidade de lesão ou morte celular causado pelo método utilizado.

No que se refere à concentração das células provindas da medula óssea e sua relação com a atividade osteogênica, vários trabalhos mostram que quanto maior o número de células, maior a atividade reparativa no local. Connolly (1995) compara após a implantação na cavidade abdominal de coelhos, a capacidade osteogênica de aspirados de medula óssea isoladamente com o obtido por vários métodos de centrifugação. O objetivo da centrifugação foi promover uma maior concentração de células/ml no material a ser implantado. Os resultados revelaram maior quantidade de tecido ósseo neoformado nas implantações feitas com o material centrifugado, comprovando assim que a osteogênese no interior das câmaras é diretamente proporcional à concentração celular da solução osteogênica. Mesmos achados feitos em humanos por Hernigou et al. (2005) e Ye et al. (2012) que confirmaram a importância do emprego de técnicas para aumento da concentração de células osteoprogenitoras a serem administradas localmente no tratamento e regeneração dos defeitos ósseos.

Assim procuramos utilizar o maior número de osteoblastos a serem implantados no defeito ósseo alveolar, numa concentração de $3,3 \times 10^{5}$ células $/ \mathrm{ml}$, e possivelmente conseguir maior efeito osteogênico durante a cicatrização óssea, número este que tem semelhança com os trabalhos de Kasten et al. (2006), utilizando $2 \times 10^{5}$ células $/ \mathrm{ml}$ e Nair et al. (2008), $5 \times 10^{5}$ células $/ \mathrm{ml}$.

Lacerda et al. (2009) compararam o uso das células tronco expandidas e diferenciadas em osteoblastos com o osso autógeno na reparação óssea alveolar 
pós-extração. Os resultados histométricos revelaram que a associação $\mathrm{CO}+\mathrm{OA}$ produziu aumento significativo (15\%) de trabéculas ósseas nos períodos experimentais estudados comparados ao grupo controle. Concluíram que células osteoblásticas associadas ao osso autógeno aceleraram a reparação óssea.

Recentemente, Macedo et al. (2011) também utilizando a mesma metodologia acima citada demonstraram que a associação de células osteoblásticas/osso autógeno foram capazes de compensar os efeitos deletérios causados pela cafeína no processo de reparação de alvéolos dentáros.

Embora estudos tenham confirmado a superioridade da terapia com células tronco mesenquimais expandidas em culturas em relação à utilização de aspirados de medula óssea (Kadiyala et al., 1997), estas culturas aumentam substancialmente custos e riscos. Complicações como contaminação com bactérias e vírus e depleção da capacidade proliferativa das células tronco mesenquimais antes da sua implantação têm sido relatadas. Além disso, a preferência pela seleção in vitro das células com maior potencial proliferativo pode causar a escolha de células com mutações e capazes de dar origem a tumores, como teratomas. No presente estudo, durante a análise qualitativa, não foi observado nos alvéolos dos animais que receberam as células osteoblásticas carreadas ou não pela biocerâmica a formação de massas celulares tumorais ou crescimentos que se diferenciaram da cicatrização óssea regular descrita na literatura (Figuras 10C, 13C e 16C).

Os osteoblastos utilizados nesta pesquisa foram alógenos, ou seja, tiveram como fonte doadora a medula óssea de um animal da mesma espécie. Estudos sugerem que o uso deste tipo de transplante de células tronco mesenquimais poderia não ser rejeitado na ausência de imunossupressão, inclusive em modelos animais (Bartholomew et al., 2001; Devine et al., 2003). 
Arinzeh et al. (2003) estudaram os efeitos do uso das células tronco alógenas na reparação óssea em defeitos críticos na diáfise femoral de cães. Os resultados mostraram que quanto à reparação óssea, houve um aumento na taxa de cicatrização e um novo osso foi capaz de preencher o defeito presente, e quanto ao comportamento das células alógenas frente ao organismo receptor, nenhuma resposta adversa do hospedeiro pode ser detectada durante o experimento nem anticorpos contra as mesmas. Os autores concluíram que as células utilizadas neste modelo puderam melhorar a capacidade reparativa óssea sem o uso de terapia imunossupressiva, e na ausência de respostas imunes adversas. Em 2008, Planka et al. estudaram em coelhos o uso de células tronco mesenquimais autógenas ou alógenas no reparo de defeitos femorais em coelhos. Puderam observar que não houve diferenças quanto à reparação do defeito entre os tipos celulares utilizados, e quanto ao transplante alógeno, nenhuma rejeição foi encontrada.

Em 2011, Badiavas e Badiavas afirmaram que o uso das células tronco mesenquimais heterólogas obtidas de doadores jovens podem apresentar vantagens, em procedimentos reparativos, quando comparadas às autólogas provenientes de doadores mais velhos e com problemas sistêmicos. Esta informação está de acordo com o modelo de obtenção das células por nós escolhido, em que a medula óssea é retirada de um animal bastante jovem com cinco semanas de idade e pesando aproximadamente 100 a 120 gramas.

O uso destas células alógenas pode ser encorajado na reconstrução óssea como afirmado por Zhao et al. (2011), onde estes autores lançaram mão das mesmas sem medicação imunossupressora nos procedimentos relacionados a união atrófica após fraturas de ossos longos. 
Alguns estudos têm indicado que as células tronco mesenquimais osteoprogenitoras possuem propriedades imunológicas privilegiadas, na qual evitam ou suprimem de certa forma a resposta imune causadora de rejeição na maioria das células e tecidos. Esta característica pode ser explicada pela insensibilidade e forte supressão na proliferação dos linfócitos T (Di Nicola et al., 2002; Bartholomew et al., 2002), somado a expressão nestas células osteoprogenitoras de uma variedade de receptores de membrana Toll-like, e que a sinalização por estes é capaz influenciar a migração, sobrevivência, diferenciação e resposta imunossupressora (Griffin et al., 2010). O presente trabalho não teve como foco a análise minuciosa das respostas imunológicas através de meios específicos, por isso estudos mais avançados devem ser realizados a fim de realmente esclarecer se alguma mudança bioquímica e celular possa ter ocorrido com o uso das células de origem heteróloga.

Na microscopia de luz, qualitativamente os alvéolos dos animais que foram submetidos à implantação das células osteoblásticas isoladas ou em associação aos outros materiais de enxerto utilizados nesta pesquisa mostraram que as mesmas são biocompatíveis, isenta de reação de corpo estranho e formações tumorais durante o período experimental, (Figuras 10C; 12B, E e F; 13C; 15B, E e F; 16C; 18B, E e F).

Além da implantação direta das células osteoblásticas no defeito ósseo primeiramente através de pipeta, o osso autógeno serviu como um material osteocondutor para as células, pois o mesmo foi previamente mergulhado no concentrado celular antes da implantação no alvéolo (Grupo $O A+C O$ ), pois é conhecida a existência de algum grau de microporosidade na arquitetura deste tipo de tecido, apesar da sua característica cortical. 
$\mathrm{Na}$ histometria, os animais implantados com as células osteoblásticas sozinhas revelaram quantidades de tecido ósseo neoformado maiores em comparação aos grupos controle (significante a 1\%), osso autógeno (sem significância) e osso autógeno + células osteoblásticas (significante a 1\%) aos 7 dias (Tabela 1 e Figura 27) (Tabela 4). Esta maior porcentagem possivelmente ocorreu devido ao aporte adicional de células viáveis em comparação aos demais grupos, aumentando assim o poder osteogênico local. Já o menor valor numérico de 32,9\% encontrado no grupo $\mathrm{OA}+\mathrm{CO}$ possa ter ocorrido devido à presença das partículas de osso autógeno, cuja inserção juntamente com as células osteoblásticas possa ter perturbado o estabelecimento e desenvolvimento inicial das mesmas no interior do alvéolo.

Aos 21 dias, a análise quantitativa da neoformação óssea (Tabela 2 e Figura 28) dos grupos com enxerto das células osteoblásticas isoladas (grupo CO) ou juntamente com o osso autógeno (grupo $\mathrm{OA}+\mathrm{CO}$ ) não revelou diferenças estatisticamente significante em relação aos grupos controle, OA e BC (Tabela 4).

Talvez este achado possa estar relacionado à falta de um carreador adequado para as células (grupo CO) ou mesmo a inabilidade/incapacidade do osso autógeno em carrear as mesmas (grupo $\mathrm{OA}+\mathrm{CO}$ ) e consequentemente não proporcionou um sítio favorável à proliferação e síntese da matriz óssea. Apesar das microporosidades presentes no tecido ósseo, o enxerto retirado da calota craniana é extremamente cortical, possuindo uma densidade e compactação alta que talvez não tenha favorecido a entrada das células no seu interior. Sem um adequado arcabouço osteocondutivo, provavelmente a viabilidade destas foi diminuindo no decorrer do processo reparacional e conjuntamente o poder osteogênico. 
No último período de análise, 42 dias (Tabela 3 e Figura 29), o valor percentual de preenchimento ósseo encontrado para estes grupos (CO e CO+OA) não apresentou diferenças estatisticamente significante em relação aos grupos controle, $\mathrm{BC}$ e $\mathrm{BC}+\mathrm{CO}$. O grupo $\mathrm{OA}$ mostrou menor valor (significante a $5 \%$ ), e os grupos $\mathrm{BC}+\mathrm{OA}$ e $\mathrm{BC}+\mathrm{CO}+\mathrm{OA}$ maiores, com significância estatística de $5 \%$ e $1 \%$ respectivamente (Tabela 4). Este menor valor encontrado para o grupo osso autógeno, talvez tenha relação com a característica reabsorção e remodelação rápida deste material de enxerto ao longo do tempo (Araújo e Lindhe, 2011).

\subsection{BIOCERÂMICA E CÉLULAS TRONCO NA REPARAÇÃO ÓSSEA}

O tratamento de grandes defeitos ósseos resultantes de trauma, infecção, ressecção de tumores ou associados às grandes reabsorções após a perda dos órgãos dentais ainda permanece como um dos grandes desafios no campo da cirurgia ortopédica e maxilofacial, e a engenharia tecidual óssea têm sido considerada atualmente uma abordagem promissora para a regeneração destes defeitos (Canceda et al., 2007).

A engenharia de tecidos é um campo interdisciplinar que combina os princípios de engenharia e pesquisa biológica básica de modo a produzir um material cujo objetivo é reparar um tecido danificado ou restaurar um defeito com a ajuda de biomateriais, células e/ou moléculas sinalizadoras (Langer, 2000).

A escolha de um biomaterial é crítico para o sucesso da engenharia tecidual óssea, por isso vários deles têm sido avaliados, tais como a matriz óssea desmineralizada (Kasten et al., 2003), osso alógeno (Seebach et al., 2010), osso bovino desmineralizado (Rickert et al., 2011), biopolímeros (Miranda et al., 2011; 
Zhang et al., 2012), vidros bioativos (Livingston et al., 2002) e cerâmicas (Shayesteh et al., 2008), pois um adequado carreador é essencial a atividade de células osteoprogenitoras, fatores de crescimento, hormônios e proteínas, o que refletirá na diferenciação, migração, proliferação e síntese da matriz osteóide a fim de reconstruir o osso perdido (Arvidson et al., 2011; Janicki e Schmidmaier, 2011).

O presente trabalho procurou construir um material de enxerto híbrido através da engenharia tecidual, utilizando as células tronco mesenquimais diferenciadas em osteoblastos e expandidas em laboratório, para serem carreadas por uma biocerâmica de fosfato de cálcio bifásica, composta de hidroxiapatita (HA) e fosfato tricálcio $\beta(\beta-\mathrm{TCP})$, antes da implantação no alvéolo dentário dos animais. Este carreador foi escolhido, pois apresenta grande parte das características ideais para um carreador, que são porosidade, tamanho dos poros e interconectividade adequada, estrutura química semelhante à matriz calcificada extracelular, ser biodegradável e possuir propriedades osteoindutoras e osteocondutoras (Petrovic et al., 2012).

Goshima et al., (1991) foram um dos primeiros a demonstrar a deposição de um novo osso nas porosidades das cerâmicas de fosfato de cálcio semeadas com as células tronco mesenquimais, onde o composto de células/carreador foi implantado subcutaneamente em ratos. Posteriormente outros autores obtiveram resultados equivalentes em modelos semelhantes usando diferentes espécies de ratos (Komlev et al., 2006; Liu et al., 2007), animais de grande porte como cães e cabras (Fellah et al., 2008; Vahabi et al., 2012), e humanos (Shayesteh et al., 2008).

A fim de recriar um microambiente semelhante ao encontrado in vivo, as células em cultura necessitam de se aderirem e crescerem em um arcabouço tridimensional capaz de proporcionar a interação célula-célula e expressar as 
diferentes funções características. Além da necessidade de um bom carreador, uma concentração mínima destas células é importante para o desempenho osteogênico desta associação (Minuth et al., 1998).

A formação óssea em sítios ectópicos é mais difícil que em sítios ortotópicos, pois nos primeiros não há um microambiente favorável à reestruturação tecidual pela presença de proteínas e fatores de crescimento específicos direcionando o reparo ósseo como existe no segundo sítio. A densidade crítica destas células necessárias para o satisfatório crescimento ósseo ainda é debatido, mas em sítios ectópicos os resultados histológicos in vivo são positivos e em geral a concentração mínima de suspensão de células necessária para a osteogênese é de $2,0 \times 10^{6}$ células $/ \mathrm{ml}$ (Ye et al., 2012).

Sabendo que a formação óssea ortotópica é mais favorável que a ectópica, o número de células a ser colocado nestes sítios de reconstrução pode ser menor, assim neste presente estudo foi utilizado uma concentração de $3,3 \times 10^{5}$ células $/ \mathrm{ml}$, o que está de acordo com os trabalhos de Kasten et al. (2006), Nair et al. (2008), Matsushima et al. (2009), Baba et al. (2010) e Vahabi et al. (2012).

É relatado que quanto maior a concentração de células osteoblásticas no interior do material carreador maior é o potencial osteogênico desta combinação (Hernigou et al., 2005; Ye et al., 2012), devido a melhor colonização das regiões mais profundas do biomaterial, como evidenciado in vitro por Lode et al. (2008), quando da observação de elevadas atividades proliferativas e de diferenciação das células tronco osteoprogenitoras. Além da concentração celular, o momento de inoculação das células no material carreador é importante, pois melhores resultados quanto à osteogenicidade é conseguido com a pré-semeadura das células no material carreador em laboratório do que no momento da cirurgia (Baba et al., 2010). 
Vários métodos de semeadura/inoculação de células para o interior dos carreadores são propostos (Hasegawa et al., 2010), tradicionalmente o sistema de embebição em que o biomaterial é colocado no interior dos frascos contendo as células em meio de cultura tem sido adotado (Vahabi et al., 2012), assim como alternativamente estas também podem ser pipetadas sobre o material (Zhang et al., 2010), ou ainda através de um sistema onde há baixa pressão ou vácuo (Wang et al., 2006).

A maioria dos biomateriais à base de cerâmicas de fosfato de cálcio para reconstrução óssea necessita de uma estrutura porosa para o bom desempenho osteoreconstrutor, no entanto tal característica pode negativamente aprisionar bolhas de ar nestas estruturas, o que dificultaria a entrada das células no interior do carreador. Assim vários outros métodos têm sido utilizados visando à remoção destas bolhas a fim de aumentar a densidade osteoblástica nestes compostos (Hasegawa et al., 2010).

Um dos meios propostos para resolver este efeito é a centrifugação para o interior do biomaterial poroso da suspensão celular elaborada em laboratório (Godbey et al., 2004; Roh et al., 2007; Beloti et al., 2009). Baseado nisto é que utilizamos também este método para semear as células osteoblásticas diferenciadas e expandidas em laboratório nas porosidades da biocerâmica, com o objetivo de que estas encontrariam um melhor ambiente para a formação óssea quando da implantação da associação no interior do alvéolo dentário dos animais.

A análise do potencial osteogênico da associação das células osteoblásticas utilizando a biocerâmica como carreador foi realizada através de parâmetros histológicos qualitativos e quantitativos, e assim relacionou-se o seu comportamento à dinâmica do processo reparacional ósseo intra-alveolar. 
Qualitativamente aos sete dias, os cortes histológicos dos animais que receberam a implantação das células osteoblásticas carreadas pela biocerâmica (grupo $\mathrm{BC}+\mathrm{CO}$ ), ou pela adição também do osso autógeno (grupo $\mathrm{BC}+\mathrm{CO}+\mathrm{OA}$ ), demonstraram um bom desempenho destas associações, na qual uma deposição óssea mais efetiva pode ser observada quando em comparação aos demais grupos experimentais avaliados (Figura 10).

A implantação do material híbrido construído através da engenharia tecidual pela combinação das células osteoblásticas e biocerâmica demonstrou para estes dois grupos em questão $(\mathrm{BC}+\mathrm{CO}$ e $\mathrm{BC}+\mathrm{CO}+\mathrm{OA})$ adequada atividade sintética dos osteoblastos culminando com uma matriz osteóide mais compacta, mineralizada e madura entre os grânulos da biocerâmica (Figuras 12E e F), quando comparados aos animais que receberam a biocerâmica sem a adição das células (Grupos BC e $\mathrm{BC}+\mathrm{OA})($ Figuras 12C e D).

Paralelamente a estes achados histológicos, a análise histométrica destes grupos revelou ao $7^{\circ}$ dia grandes porcentagens de preenchimento ósseo pelo uso desta associação (Tabela 1 e Figura 27). O grupo de animais implantados com a biocerâmica + células osteoblásticas $(\mathrm{BC}+\mathrm{CO})$ obteve um percentual numérico de $47,8 \%$, valor este maior que o de todos os demais grupos avaliados, com significância estatística a 1 e $5 \%$ (Tabela 4), exceto pelos valores dos grupos $\mathrm{BC}+\mathrm{OA}$ e $\mathrm{BC}+\mathrm{CO}+\mathrm{OA}$, que foram superiores.

Quando da avaliação da potencialidade e do desempenho do carreador biocerâmico para com as células osteoblásticas, a comparação foi feita entre o grupo que continha um carreador $(B C+C O)$ e o que não possuía $(C O)$, de onde pode ser demonstrado que o uso de um arcabouço para estas células se desenvolverem no interior do alvéolo dentário se faz necessário, pois um preenchimento ósseo de 
$47,8 \%$ foi encontrado para o primeiro grupo e de $38 \%$ para o segundo (Tabela 1 e Figura 27), com diferença estatisticamente significante a $5 \%$.

Apesar de que a própria presença da biocerâmica no interior do alvéolo aumenta tal valor mensurado, a análise quantitativa específica do tecido ósseo neoformado (tecido ósseo vital) realizado nas proximidades da biocerâmica revelou uma porcentagem de $18,56 \%$, o que se traduz em uma taxa relativamente adequada, para o período em questão, de matriz osteóide recém-sintetizada em alvéolos contendo material de preenchimento (Tabela 7 e Figura 32). É sabido que os materiais de preenchimento ósseo quando utilizados nos alvéolos dentais pósextração são de certa forma reconhecidos como um corpo estranho no início (Pedrosa et al., 2011), e que a própria presença do mesmo ocupa um volume onde seria depositado tecido ósseo vital, mas um dos principais motivos do uso destes biomateriais pelos clínicos é que estes são capazes de retardar ou mesmo prevenir a remodelação das tábuas ósseas, em especial a vestibular, durante o progresso da atividade reparadora (Silva et al., 2010)., daí a necessidade de se ajustar exatamente o grau de reabsorção destes compostos reconstrutores de acordo com a síntese de novo osso

Quanto à avaliação da efetividade das células osteoblásticas em sintetizar novo osso nos alvéolos dentais, a histometria comparativa realizada aos 7 dias (Tabela 1 e Figura 27) revelou que o uso das mesmas no interior da biocerâmica foi benéfico à deposição da matriz óssea, pois um preenchimento ósseo intra-alveolar de $47,8 \%$ para o grupos $\mathrm{BC}+\mathrm{CO}$ foi encontrado contra $42,7 \%$ do grupo em que a biocerâmica foi utilizada isoladamente (BC), diferença esta estatisticamente significante a $5 \%$. Este achado está de acordo com os resultados de Jafarian et al., (2008), Vahabi et al., (2012), cuja pesquisa revelou também melhor desempenho 
quanto à deposição óssea com o uso da associação biocerâmica/células osteoblásticas em relação à implantação isolada do biomaterial em questão.

Comparativamente, o grupo em discussão $(\mathrm{BC}+\mathrm{CO})$ obteve valor menor que o grupo onde a biocerâmica foi utilizada em associação ao osso autógeno ( $\mathrm{BC}+\mathrm{OA})$, mas sem diferenças estatisticamente significante (Tabela 4). Tal resultado superior deste último grupo provavelmente ocorreu pela presença das partículas do osso autógeno enxertadas no interior alveolar, que podem ser contabilizadas pela histometria, o que não foi utilizado no primeiro, onde as células carreadas pelo biomaterial não fornecem estruturas físicas capazes de serem mensuradas ao microscópio de luz pelo método utilizado neste trabalho. Deste achado podemos notar que as células implantadas foram capazes de sintetizar novo tecido ósseo e mesmo assim conseguir valores de preenchimento ósseo bastante próximo ao do grupo $\mathrm{BC}+\mathrm{OA}$, no qual as partículas de osso autógeno também tiveram um efeito somativo à porcentagem óssea total alveolar (Tabela 1 e Figura 27). Quanto ao tecido ósseo vital, os animais que receberam a biocerâmica com os fragmentos ósseos apresentaram maior valor $(23,2 \%)$ em comparação a associação célula/carreador (18,5\%) (Tabela 9 e Figura 34), provavelmente pela característica acima discutida, com significância estatística a 5\% (Tabela 13).

O bom resultado reparador ósseo observado no interior do alvéolo dentário dos animais implantados com as células osteoblásticas carreadas pela biocerâmica (grupo $\mathrm{BC}+\mathrm{CO}$ ) provavelmente ocorreu devido à presença destas células, pois as mesmas agiram como um suplemento adicional sintetizador de matriz óssea, bem como pela boa capacidade deste biomaterial em servir como carreador celular, proporcionando um maior poder osteogênico ao processo reconstrutor ósseo intraalveolar, assim como foi relatado por Hernigou et al. (2005) e Ye et al. (2012). 
A capacidade da biocerâmica em carrear estas células ocorreu principalmente devido a suas características estruturais. Primeiramente a porosidade, que é por volta de $90 \%$, possibilitou uma grande área superficial com a presença de vários sítios de ligações proteicas viáveis na sua superfície, o que teria refletido em uma maior concentração de proteínas com ligação aos cristais de HA/ $\beta$-TCP de um lado e com ligantes às células de outro, o que por consequência acreditamos que possibilitou a união com um maior número de células osteoblásticas pré-inseridas no biomaterial, e esta adesão aconteceu de forma mais estável (Zhu et al., 2010).

Além da porosidade, em segundo lugar o diâmetro dos poros deste material com média de $250 \mu \mathrm{m}$ (Figura 19B), tenha possibilitado melhores características micro ambientais agora para o desenvolvimento, replicação e síntese das células osteoblásticas já aderidas à superfície, pois como demonstraram Karageorgiou e Kaplan (2005), os arcabouços desenvolvidos com o objetivo de carregar células não devem possuir poros com diâmetros menores que $200 \mu \mathrm{m}$, tal característica limita a sobrevivência de osteoblastos e consequentemente a formação óssea se dá na periferia do material, diminuindo desta forma a oxigenação e a difusão de nutrientes para as partes mais profundas do biomaterial. Por outro lado, estudos têm demonstrado que arcabouços construídos com poros amplos de volume acessível (> $200 \mu \mathrm{m}$ ) exibem aumentada proliferação e diferenciação osteoblástica através do material, como resultado de um aumento na capacidade de transporte de oxigênio e nutrientes, bem como da neovascularização (Kuhne et al., 1994; Holtorf et al., 2005; Volkmer et al., 2008).

Em terceiro lugar é relatado a importância da uniformidade geométrica dos poros, pois a heterogeneidade dos mesmos pode desencadear regiões com insuficiente concentração de nutrientes, inibindo a própria atividade celular e 
eventualmente prevenindo a formação óssea homogênea no interior do biomaterial (Choi et al., 2010). Como podemos observar pela imagem da microscopia eletrônica de varredura da biocerâmica em estado puro antes da inserção das células e implantação no alvéolo dentário (Figura 19), existe certa homogeneidade quanto à forma dos poros bem como a dimensão e distribuição pelo material, o que provavelmente possa ter evitado o problema acima citado.

Por último, esta biocerâmica possui uma adequada interconectividade ente os poros (Figura 19C), ou seja, boa conexão entre eles. Os poros de um determinado material podem ser tanto interligados quanto conhecidos como "beco sem saída" (Blokhuis et al., 2000), esta característica é de grande importância a fim de possibilitar a neovascularização, o movimento celular, a troca de nutrientes entre as células e também o crescimento ósseo no interior do biomaterial (Lecomte et al., 2008). Alguns autores têm sugerido que o tamanho dos canais de interligação e, consequentemente a capacidade do material cerâmico em ser penetrado por fluido e células, é um dos fatores que limitam a osteocondução da mesma forma que o tamanho dos poros (Chang et al., 2000). Aos 7 dias, já foi possível demonstrar a adequada interconectividade dos poros da biocerâmica, visto que ocorreu o crescimento ósseo nesta região (Figura 12F), confirmando que este biomaterial pode cumprir com as características discutidas neste parágrafo.

Quando as partículas do osso autógeno removidas da calota craniana foram implantadas no interior alveolar juntamente com o composto biocerâmica/células osteoblásticas (Grupo BC+CO+OA), uma deposição óssea mais efetiva e superior a todos os demais grupos estudados nesta pesquisa pode ser observado (Tabela $1 \mathrm{e}$ Figura 27). Uma porcentagem de preenchimento ósseo alto para o período em questão (7dias) de $52,4 \%$ pode ser mensurada, com diferenças estatisticamente 
significantes a $1 \%$ quando comparados aos grupos controle, $\mathrm{OA}, \mathrm{CO}, \mathrm{OA}+\mathrm{CO}$ e $\mathrm{BC}$ (Tabela 4).

A análise da quantidade de tecido ósseo neoformado, para este mesmo grupo, depositado nos arredores da biocerâmica (tecido ósseo vital) foi de $25,2 \%$ (Tabela 9 e Figura 34), percentual este maior que o encontrado para os animais implantados com a BC que foi de 16,1\% (significância de 1\%), 23,2\% para o grupo BC+OA (sem significância) e de 18,5\% para BC+CO (significância de 1\%), (Tabela 13).

A histometria mostrou aos 7 dias que a reparação óssea foi significantemente acelerada com esta combinação, sugerindo um efeito sinérgico entre os biomateriais, ou seja, enquanto as células osteoblásticas carreadas pela biocerâmica apresentaram adequado desempenho osteogênico, osteocondutivo e possivelmente osteoindutivo, o osso autógeno pode agir como um material de preenchimento altamente biocompatível, com boas propriedades osteocondutoras, osteogênicas e capaz de fornecer BMPs ao sítio em reparação. Esta associação provavelmente apresentou além das características acima, propriedades quimiotáticas, atraindo ainda mais células osteoprogenitoras e osteoblastos para a região, promovendo aceleração da reparação óssea neste período inicial.

A análise qualitativa feita aos 21 dias dos alvéolos dentários dos animais implantados com a biocerâmica e células osteoblásticas $(B C+C O)$ e também com a adição do osso autógeno $(\mathrm{BC}+\mathrm{CO}+\mathrm{OA})$ demostraram um trabeculado ósseo espesso e maduro quando em comparação aos demais grupos analisados (Figura 13). Em um maior aumento, estes dois grupos apresentaram uma deposição de tecido ósseo neoformado na quase totalidade da periferia dos grânulos da biocerâmica (Figura 15E e F), sendo que este tecido foi capaz de fazer a união entre 
a biocerâmica e os fragmentos de osso autógeno (Figura 15 F). Já neste período foi possível observar a osteointegração da biocerâmica ao osso recém sintetizado também através da microscopia eletrônica de varredura (Figuras 22 e 23), sem a interposição de tecido mole.

Neste mesmo período (21 dias) a análise histométrica do grupo $\mathrm{BC}+\mathrm{CO}$ apresentou um nível de preenchimento ósseo maior que todos os grupos estudados (Tabela 2 e Figura 28) exceto o grupo onde os três biomateriais foram utilizados conjuntamente $(B C+C O+O A)$. A análise estatística demonstrou diferenças a $1 \%$ quando em comparação aos grupos $\mathrm{OA}, \mathrm{CO}$ e $\mathrm{OA}+\mathrm{CO}$, a $5 \%$ com relação ao controle e BC, e sem significância estatística quando comparado ao BC+OA (Tabela 4).

Este achado provavelmente ocorreu em grande parte devido ao efeito osteogênico das células osteoblásticas carreadas pela biocerâmica, pois neste período aparentemente a presença da biocerâmica não aumentou em grandes proporções o nível de preenchimento ósseo, de modo que ao compararmos o valor encontrado de $57,4 \%$ para o grupo BC com o dos animais controle de $58,4 \%$, podemos observar que estes valores são bem próximos, o que demonstra que a biocerâmica já não mais eleva o percentual de forma acentuada como em 7 dias, quando comparado aos demais grupos onde ela não foi utilizada (Tabela 2 e Figura 28). Assim no grupo $B C+C O$ em comparação ao $B C$, a única variável adicional encontrada foi a presença das células osteoblásticas, podemos deste modo inferir que as mesmas sintetizaram maior quantidade de matriz óssea no interior alveolar.

Quando este grupo em questão $(\mathrm{BC}+\mathrm{CO})$ foi comparado aos animais do grupo BC+OA (Tabela 2 e Figura 28), valores bem próximos foram encontrados (sem significância estatística) (Tabela 4), isto provavelmente ocorreu devido a 
presença das partículas de osso autógeno no interior do alvéolo contabilizadas juntamente com a biocerâmica e também pela capacidade dos fragmentos autógenos em estimular a neoformação óssea pela libração de BMPs à medida que sua reabsorção ocorria.

A combinação das células osteoblásticas carreadas pela biocerâmica juntamente com as partículas do osso autógeno $(\mathrm{BC}+\mathrm{CO}+\mathrm{OA})$ proporcionaram o maior preenchimento ósseo alveolar $(67,1 \%)$ para o período de 21 dias (Tabela 2 e Figura 28). Em comparação aos grupos $B C+O A$ e $B C+C O$ não houve diferenças estatisticamente significantes, e quanto aos demais, os níveis encontrados foram de 1 e $5 \%$, que podem ser consultados na tabela 4 .

Da observação realizada na tabela 2 e figura 28 podemos perceber que o uso do osso autógeno e das células osteoblásticas isoladamente (Grupos OA e CO) ou mesmo da combinação destes dois biomateriais (Grupo $\mathrm{OA}+\mathrm{CO}$ ) não elevou o preenchimento alveolar acima do encontrado para o grupo controle, característica esta também encontrada para os animais que receberam a biocerâmica isoladamente (Grupo BC). Portanto podemos concluir, neste período intermediário da reparação óssea, que o uso isolado do osso autógeno ou das células osteoblásticas, ou estes dois associados não trouxeram grandes efeitos ao preenchimento ósseo total do alvéolo dentário, da mesma forma que a biocerâmica isolada, sendo necessário para esta o fornecimento de um conteúdo celular adicional através das células osteoblásticas ou do osso autógeno com suas propriedades osteocondutoras, osteoindutoras e também osteogênicas a fim de favorecerem a atividade sintetizadora local.

Esta maior atividade sintetizadora dos osteoblastos aos 21 dias pode ser confirmada pela análise do tecido ósseo neoformado (tecido ósseo vital) depositado 
nos arredores da biocerâmica (Tabela 9 e Figura 34), pois onde as células osteoblásticas ou o osso autógeno, ou mesmo ambos foram utilizados, uma deposição óssea mais expressiva foi observada. A comparação entre os grupos $\mathrm{BC}+\mathrm{OA}, \quad \mathrm{BC}+\mathrm{CO}$ e $\mathrm{BC}+\mathrm{CO}+\mathrm{OA}$ com o grupo $\mathrm{BC}$ demonstra diferenças estatisticamente significante a $1 \%$ (Tabela 13$)$.

No último período da análise, 42 dias, qualitativamente podemos observar tanto para os cortes realizados nos animais do grupo $\mathrm{BC}+\mathrm{CO}$ quanto para $\mathrm{O}$ $\mathrm{BC}+\mathrm{CO}+\mathrm{OA}$ um trabeculado ósseo muito bem formado com bastante maturidade e densidade (Figuras 16G e H), evidenciando que uma ótima atividade reparativa óssea ocorreu no alvéolo dentário. A quase totalidade dos grânulos da biocerâmica carreando as células osteoblásticas apenas (grupo $\mathrm{BC}+\mathrm{CO}$ ) e juntamente com $\mathrm{O}$ osso autógeno da calvária (grupo $\mathrm{BC}+\mathrm{CO}+\mathrm{OA}$ ) foi circunscrita pelo tecido ósseo neoformado, fornecendo uma osteointegração consistente com estes biomateriais (Figura 18E e F), o que também pode ser confirmado pela MEV em aumentos de grande expressão (Figuras 24 e 25).

Estas características acima são importantes, pois com o avanço dos procedimentos reconstrutores ósseos em implantodontia, espera-se que uma adequada densidade trabecular e uma ligação consistente entre o material de enxertia e o tecido ósseo recém-sintetizado nativo ocorram (Pedrosa et al., 2011). Este objetivo é buscado principalmente para satisfazer as características mecânicas do tecido ósseo reconstruído, pois assim como na ortopedia, os ossos da região oral necessitam também de adequada resistência, a fim de suportar os esforços recebidos durante o ato mastigatório, principalmente quando estes recebem os implantes osteointegrados de titânio como forma de reabilitação do órgão dentário perdido. Se uma integração fraca é encontrada entre o biomaterial e o tecido ósseo 
no sítio reconstruído, há um aumento na probabilidade de que um rompimento desta ligação ocorra durante a aplicação das cargas fisiológicas, e dependendo da magnitude das forças, desde uma microfratura nesta interface, sem consequências clínicas, até uma fratura mais extensa de toda região enxerta pode ocorrer, inviabilizando em muitos casos a instalação e mesmo a manutenção a longo prazo dos implantes de titânio (Khoury, 2011).

A propriedade mais frequentemente usada para caracterizar o comportamento mecânico de substitutos ósseos é a sua resistência à compressão, uma vez que esses materiais se destinam a ser utilizados como substitutos deste tecido, é importante ter em mente que a força de compressão do osso cortical humano varia entre 90 e $230 \mathrm{MPa}$ (com uma resistência à tração que vai de 90-190 MPa), enquanto que a resistência à compressão do osso esponjoso varia entre 2 e $45 \mathrm{MPa}$ (An, 2000). Comparado a estas informações os fosfatos de cálcio geralmente fornecem limitado suporte biomecânico, porque são frágeis e têm pouca resistência à tração (Hannink e Arts, 2011), embora a porosidade e o tamanho dos poros aumentado facilitam o crescimento interno de osso, o resultado é uma redução das propriedades mecânicas, pois isto compromete a integridade estrutural do arcabouço. Além disso, biocerâmicas fabricadas com uma elevada taxa de degradação não devem ter porosidade elevada (> 90\%), uma vez que o esgotamento/reabsorção rápida do material no sítio reconstruído irá comprometer a integridade estrutural e mecânica antes da substituição por novo tecido ósseo (Karageorgiou e Kaplan, 2005).

O material cerâmico por nós utilizado não foi submetido a testes mecânicos após sua implantação no alvéolo dentário dos animais, mas acreditamos que o mesmo poderia ter revelado bons resultados se o fossem feitos. Apesar do 
biomaterial em questão neste estudo possuir alta porosidade, histologicamente foi constatado o crescimento/preenchimento por tecido ósseo nos poros da biocerâmica (Figuras 12F, 15C e 18E), que de certa forma possa ter proporcionado uma maior rigidez ao conjunto biomaterial/osso. Também a sua biodegradação, como explicada em parágrafos acima, parecia ser compatível com a neoformação óssea, pois durante a avaliação histológica não foi possível observar vazios em meio aos tecidos esperando para a deposição de novo tecido mineralizado. Aliado a estas características, a adequada ligação interfacial osso/biocerâmica sem a presença de tecido mole, seja nos grupos com a associação das células osteoblásticas e/ou o osso autógeno, foi demonstrado nos três períodos de análise, fato este de grande importância para a estabilidade em longo prazo e a capacidade de resistir aos esforços biomecânicos sofridos por todo o conjunto ósseo reparado no interior do alvéolo dentário.

Esta osteointegração ao longo de toda a superfície da biocerâmica e também o crescimento ósseo para o interior dos poros da mesma pode ser notado na figura 18E, e neste período (42 dias) confirmou-se que um tecido de boas qualidades foi capaz ser sintetizado pelos osteoblastos no interior do biomaterial, provando que as propriedades discutidas deste material como a porosidade, tamanho dos poros e interconectividade, possivelmente estão de acordo com os parâmetros recomendados pela literatura.

Quantitativamente, a análise histométrica realizada aos 42 dias nos animais do grupo $\mathrm{BC}+\mathrm{CO}$ demonstrou uma taxa de preenchimento ósseo de $73,1 \%$ (Tabela 3 e Figura 29), este valor foi maior que os encontrados para os grupos controle, OA, $\mathrm{CO}, \mathrm{BC}+\mathrm{CO}$ e $\mathrm{BC}$, com diferenças estatisticamente significantes apenas para o grupo osso autógeno (Tabela 4). Os grupos $\mathrm{BC}+\mathrm{OA}$ e $\mathrm{BC}+\mathrm{CO}+\mathrm{OA}$ superaram tal 
valor percentual, mas significância foi encontrada apenas para o segundo (Tabela 4).

Durante a avaliação dos resultados histométricos encontrados aos 42 dias podemos observar que para praticamente todos os grupos, a taxa de preenchimento ósseo permaneceu entre 70 e $80 \%$. Este comportamento está de acordo com os dados publicados na literatura e de vários trabalhos executados pelo nosso grupo de pesquisa (Lamano-Carvalho et al., 1997; Lacerda et al., 2010; Macedo et al., 2011; Macedo et al., 2012).

O objetivo do processo de reparação dos alvéolos dentários pós-extração é preencher com tecido ósseo o espaço antes ocupado pela raiz dentária, de forma que esta área reparada se comporte naturalmente frente aos processos de reabsorção e aposição óssea, essenciais à remodelação e manutenção da vitalidade deste tecido (Carvalho e Okamoto 1987). Para o adequado desempenho destas funções é necessário uma proporção de medula óssea, que neste trabalho foi denominada tecido mole (tecido conjuntivo + coágulo), em relação ao osso. É na medula a localização da rede vascular e linfática, cujo objetivo é permitir as trocas de nutrientes essenciais ao metabolismo, e também é nesta a fonte de células osteoprogenitoras prontas a se diferenciaram em osteoblastos caso seja necessário a renovação celular. Sabendo destas necessidades é que o próprio organismo regula a porcentagem total de preenchimento ósseo em um determinado sítio, pois uma grande porcentagem de osso e uma pequena de medula óssea não seriam compatíveis com a função salutar deste tecido (Junqueira e Carneiro, 2008). Assim, podemos dizer que a maioria dos grupos já atingiu um período de equilíbrio das proporções teciduais, restando agora apenas manutenção óssea através da 
reabsorção das trabéculas ósseas já mais senis quanto dos biomateriais por nós implantado, concomitante à deposição de tecido ósseo jovem.

Sabendo da necessidade do organismo em manter a proporção acima descrita, podemos observar que a média de preenchimento ósseo aos 42 dias dos oito grupos estudados foi de $71,7 \%$, deste valor podemos notar que o grupo de expressivo destaque foi o que utilizamos as células osteoblásticas carreadas pela biocerâmica juntamente com o osso autógeno da calota craniana $(B C+C O+O A)$, com uma porcentagem de 78,9\% contabilizada (Tabela 3 e Figura 29). Este valor mostrou diferenças estatisticamente significantes a $5 \%$ em relação aos animais controle e os implantados com $\mathrm{BC}+\mathrm{CO}$, de $1 \%$ quando comparado aos do grupo $\mathrm{OA}, \mathrm{CO}, \mathrm{OA}+\mathrm{CO}$ e $\mathrm{BC}$, mas sem significância em relação aos que receberam o BC+OA (Tabela 4).

Este resultado talvez possa ter ocorrido devido a um efeito estimulador das BMPs liberadas pelo osso autógeno à medida que este ia sendo reabsorvido e remodelado durante o processo reparacional. Estas proteínas podem ter agido sobre as células osteoblásticas produzidas em laboratório e contidas na biocerâmica, bem como sobre a diferenciação de outras provindas do próprio sítio em reparação.

A quantificação do tecido ósseo neoformado (tecido vital) na periferia da biocerâmica aos 42 dias demonstra que o grupo de animais implantados com os três materiais osteoreconstrutores (Grupo $\mathrm{BC}+\mathrm{CO}+\mathrm{OA}$ ) por nós utilizados apresentou a maior porcentagem $(53,2 \%)$, número bastante próximo, sem significância estatística, também foi encontrado para o grupo $B C+O A(49 \%)$ e para o $B C+C O(52,8 \%)$. Em comparação aos animais implantados com a biocerâmica (BC) a taxa de deposição de novo osso para estes foi de $41,7 \%$ (significante a $1 \%$ ). 
Buscando saber em que período do experimento, e qual das associações realizadas com a biocerâmica apresentaram o melhor desempenho osteogênico, é que realizamos uma análise correlacionando a porcentagem de osso vital com a da biocerâmica no interior alveolar, cuja denominação foi relação osso vital/biocerâmica. A tabela 12 mostra os valores encontrados e a figura 37 demonstra através de um gráfico, a evolução de tal parâmetro ao longo do processo reparacional. Quanto maior o número encontrado nesta relação, maior também foi o desempenho osteogênico dos biomateriais de enxertia.

Na tabela 12 e na figura 37, podemos observar que dos quatro grupos de animais onde a biocerâmica foi utilizada isoladamente ou em associações, a menor atividade osteogênica aos 7 dias foi obtida no grupo com o uso isolado dos grânulos da biocerâmica (grupo BC), com um índice de 0,35 demonstrado pela linha azul. Em segundo lugar temos o grupo $\mathrm{BC}+\mathrm{CO}$ com um índice de 0,41 (Linha verde), seguido pelo grupo $\mathrm{BC}+\mathrm{OA}$ com 0,50 (Linha vermelha) e por último o de maior poder osteogênico $(0,61)$, com a associação das células carreadas pela biocerâmica conjuntamente com as partículas do osso autógeno ( $B C+C O+O A)$ (Linha Roxa).

Aos 21 dias, esta mesma análise revela que ainda o grupo BC é o de menor poder osteogênico $(0,66)$, seguido por valores quase iguais entre os grupos $B C+C O$ $(0,88), B C+C O+O A(0,89)$ e $B C+O A(0,93)$.

No último período de estudo, 42 dias, o grupo BC permanece ainda com a menor capacidade osteogênica $(1,16)$, seguido pelo grupo $B C+O A(1,22)$, pelo grupo $\mathrm{BC}+\mathrm{CO}$ em terceiro $(1,44)$, e mantendo o melhor desempenho na síntese de tecido ósseo em relação à quantidade de biocerâmica o grupo $\mathrm{BC}+\mathrm{CO}+\mathrm{OA}(1,50)$.

Da análise conjunta destes dados podemos concluir que, a biocerâmica quando utilizada sozinha é o biomaterial de menor poder osteogênico quando 
comparadas aos outros três grupos em questão. Isto se deve talvez a falta de um conteúdo celular ou mesmo de um fator de crescimento pró-osteogênico, como as BMPs contidas no osso autógeno, a fim de propiciar uma maior deposição da matriz óssea pelos osteoblastos locais.

Em relação aos grupos $\mathrm{BC}+\mathrm{CO}$ e $\mathrm{BC}+\mathrm{OA}$, o primeiro apresentou um potencial osteogênico menor aos 7 dias, se igualando ao segundo aos 21 dias e com maior potencial aos 42 dias. Este comportamento possivelmente ocorreu devido a um processo de reabsorção das partículas do osso autógeno no grupo $\mathrm{BC}+\mathrm{OA}$ com o desenrolar do processo reparacional, e sabendo que não havia um aporte adicional das células osteoblásticas, como no grupo $\mathrm{BC}+\mathrm{CO}$, a serem estimuladas com a liberação das BMPs, seu poder osteogênico caiu.

Já o grupo $\mathrm{BC}+\mathrm{CO}+\mathrm{OA}$, começou com o maior potencial osteogênico aos 7 dias, provavelmente devido a boa capacidade da biocerâmica em carrear as células e também do osso autógeno em propiciar um bom material de preenchimento ao alvéolo dentário, teve uma queda aos 21 dias, provavelmente devido a reabsorção do osso autógeno, e voltou a apresentar boa atividade aos 42 dias. Pela análise gráfica, podemos interpretar que de 7 para 21 dias o poder osteogênico para este grupo cai levemente (linha roxa), tornando-se semelhante aos grupos BC+CO (Linha verde) e $B C+O A$ (Linha vermelha). Mas a presença das células osteoblásticas é de grande importância nesta etapa da reparação de 21 para 42 dias, pois o grupo que não as possuía $(B C+O A)$ diminui seu valor no decorrer até o período de 42 dias, enquanto a presença das mesmas $(\mathrm{BC}+\mathrm{CO}$ e $\mathrm{BC}+\mathrm{CO}+\mathrm{OA})$ aumentou a deposição óssea.

Quando da comparação dos índices encontrados em 42 dias para o grupo $B C+C O(1,44)$ e para o $B C+C O+O A(1,50)$ observou-se que o segundo grupo 
apresentou um valor discretamente maior em relação ao primeiro. Acreditamos que esta diferença e o maior poder osteogênico do grupo contendo os 3 biomateriais $(\mathrm{BC}+\mathrm{CO}+\mathrm{OA})$ aos 42 dias ocorreu devido à presença dos fragmentos de osso autógeno, que por sua vez foram sendo reabsorvidos e a liberação das BMPs de sua matriz foi capaz de estimular as atividades sintetizadoras das células osteoblásticas. Visto que, com o passar do tempo e com a senilidade, as células osteoprogenitoras vão perdendo sua capacidade em produzir a matriz óssea (Badiavas e Badiavas, 2011), e talvez um estimulo adicional, como o das BMPs, possa ter auxiliado esta função.

Ao analisarmos a taxa de preenchimento ósseo encontrado para o grupo $\mathrm{BC}+\mathrm{CO}+\mathrm{OA}(52,4 \%)$ aos 7 dias (Tabela 1 e Figura 27$)$ podemos observar que tal número é bastante próximo ao encontrado no período de 21 dias (Tabela 2 e Figura 28) nos animais do grupo controle $(58,4 \%)$, osso autógeno $(54,4 \%)$, células osteoblásticas (52,3\%), células osteoblásticas + osso autógeno (55,3\%) e biocerâmica (57,4\%). Yoshikawa et al., (1996) relataram que a hidroxiapatita contendo no seu interior as células tronco mesenquimais pode ser comparada às partículas de osso autógeno esponjoso ou de medula óssea, talvez por esta propriedade é que Shayesteh et al., (2008) afirmam que este composto híbrido proporciona similar potencial osteogênico e pode ser utilizado para propósitos clínicos. Como evidenciado acima, a capacidade da biocerâmica em carrear as células osteoblásticas e ainda combinar este composto híbrido ao osso autógeno da calota craniana (Grupo BC+CO+OA), foi capaz de acelerar a deposição óssea intraalveolar nos períodos iniciais, pois valores percentuais conseguidos aos 7 dias para este grupo só foram alcançados aos 21 pelos outros relatados acima. 
Desta análise podemos concluir que o composto células osteoblásticas/biocerâmica fabricado pela engenharia tecidual em conjunto com as partículas do osso autógeno proporcionaram uma aceleração na taxa de preenchimento ósseo nos animais deste grupo em aproximadamente 14 dias, o que reflete em uma possibilidade de intervenção neste osso intra-alveolar reparado mais precoce do que o preconizado pela literatura. Sabendo que a biocerâmica implantada no alvéolo dentário dos animais apresentou uma boa adesão/união com o tecido ósseo neoformado em todos os 3 períodos experimentais, e que a mesma foi gradativamente sendo reabsorvida durante o curso da reparação alveolar, é de se esperar que no decorrer do tempo além do analisado neste trabalho, o turnover ósseo será capaz de reabsorver toda a biocerâmica implantada e substituí-la por osso vital. Assim a taxa de $78,9 \%$ de preenchimento ósseo encontrada no alvéolo dentário para o grupo $\mathrm{BC}+\mathrm{CO}+\mathrm{OA}$ aos 42 dias, possivelmente será constituída no futuro de um tecido ósseo onde não exista mais a presença de algum biomaterial. 


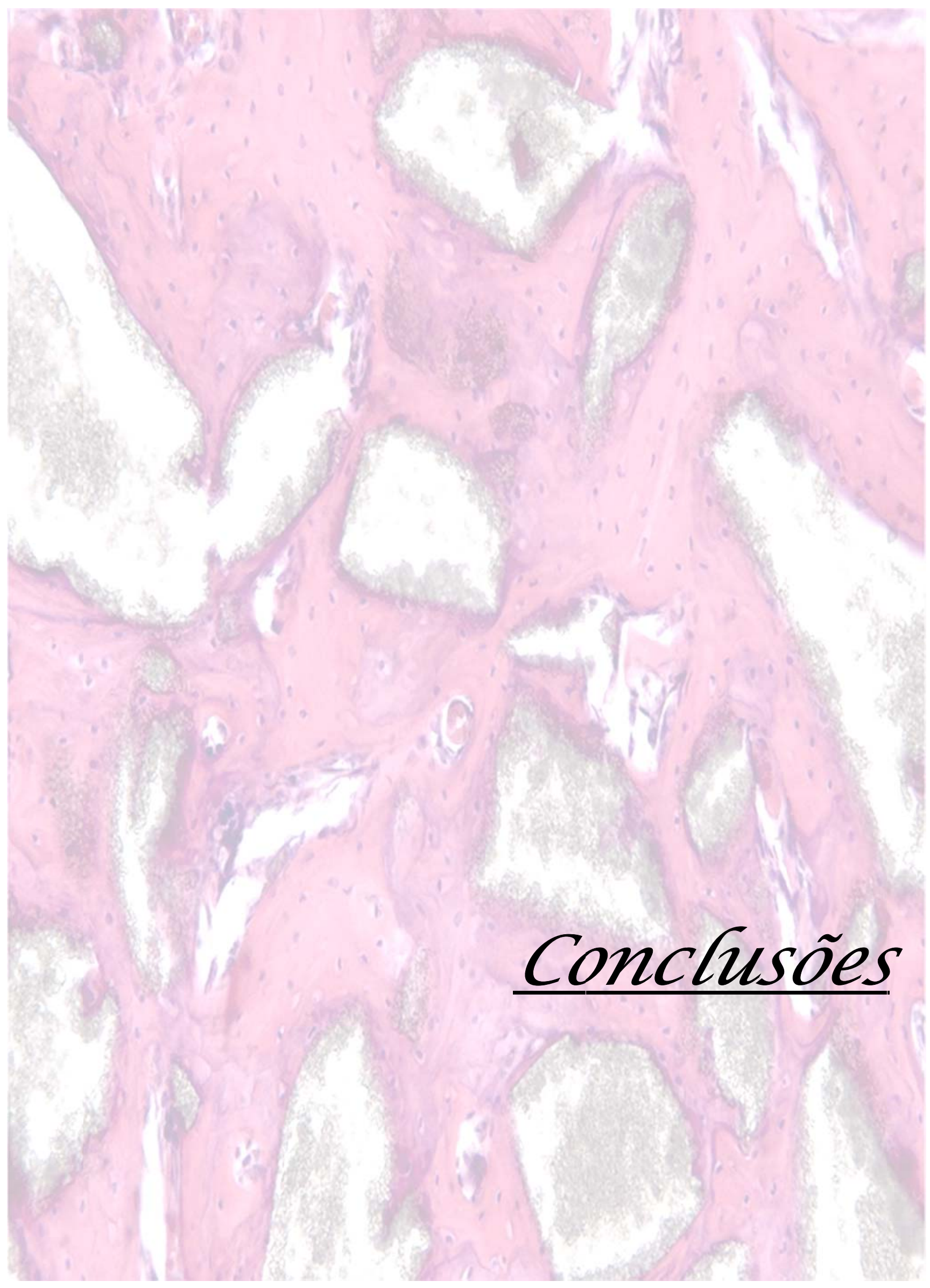




\section{Conclusões}

Dos resultados apresentados pode-se concluir que:

1. A biocerâmica de fosfato de cálcio bifásica composta de Hidroxiapatita/Fosfato tricálcio $\beta$ se mostrou biocompatível, apresentou osseointegração progressiva, foi gradualmente reabsorvida e substituída por novo osso sem interferir na dinâmica do processo de reparo ósseo alveolar.

2. As células osteoblásticas quando carreadas pela biocerâmica proporcionaram melhores atividades osteogênicas do que quando utilizadas isoladamente, evidenciando a viabilidade deste último biomaterial em servir como arcabouço/carreador celular e constituir um material de enxertia híbrido com vistas à reparação óssea.

3. O osso autógeno obtido da calota craniana promoveu um efeito sinérgico quando associado ao composto biocerâmica/células osteoblásticas, refletindo em uma deposição óssea mais efetiva no alvéolo dentário.

4. A implantação da combinação de biocerâmica/células osteoblásticas associadas ao osso autógeno revelou alto poder osteogênico intra-alveolar, estimulando a neoformação óssea principalmente nos períodos iniciais do processo de reparação óssea alveolar. 


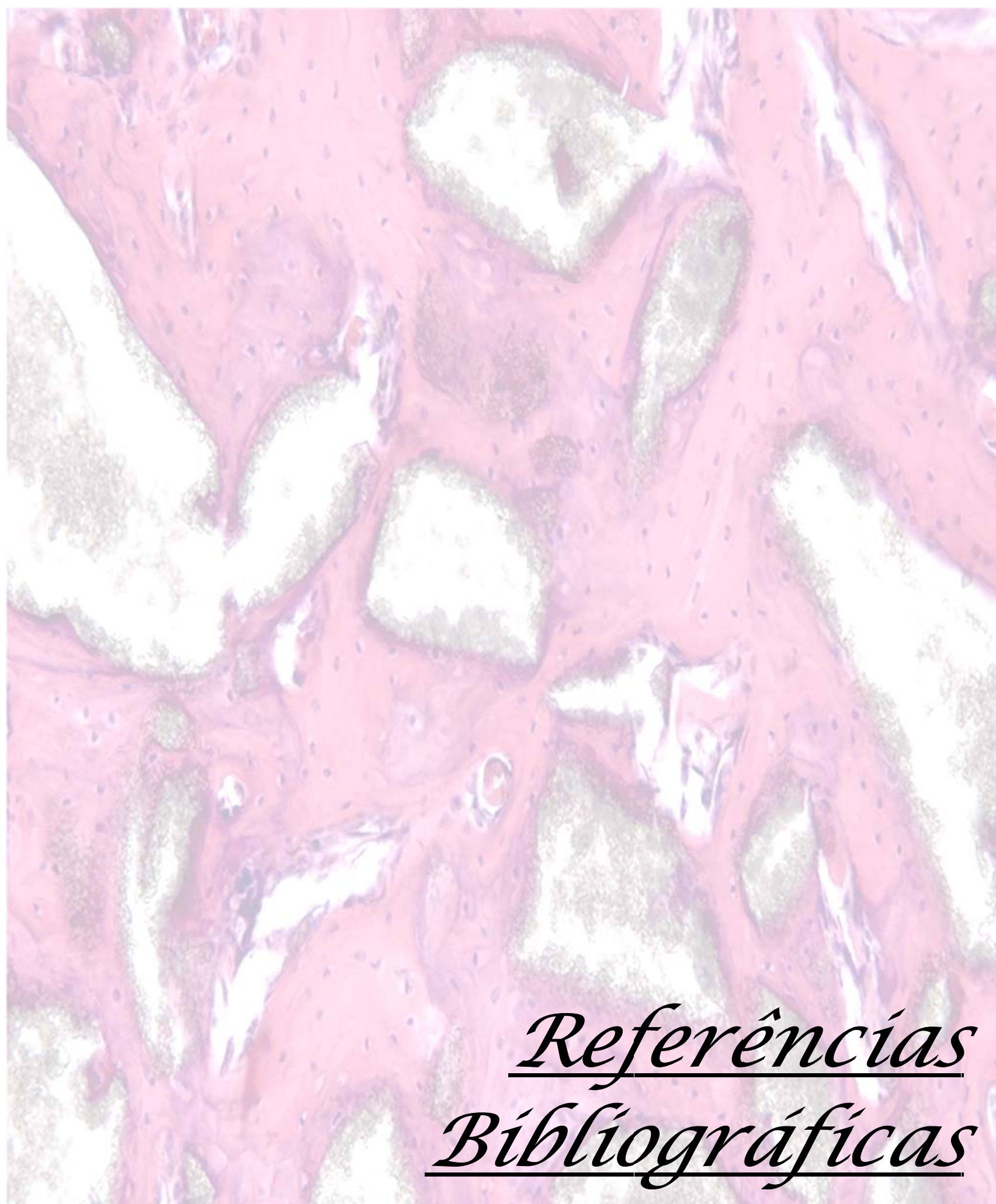




\section{Referências Bibliográficas}

1. Aguirre JI, Altman MK, Vanegas SM, Franz SE, Bassit AC, Wronski TJ. Effects of alendronate on bone healing after tooth extraction in rats. Oral Dis. 2010 Oct;16(7):674-85.

2. Ahn JJ, Shin HI. Bone tissue formation in extraction sockets from sites with advanced periodontal disease: a histomorphometric study in humans. Int J Oral Maxillofac Implants. 2008 Nov-Dec;23(6):1133-8.

3. Alam MI, Asahina I, Ohmamiuda K, Takahashi K, Yokota S, Enomoto S. Evaluation of ceramics composed of different hydroxyapatite to tricalcium phosphate ratios as carriers for rhBMP-2. Biomaterials. 2001 Jun; 22(12):164351.

4. Albee FH. Studies in bone growth: triple calcium phosphate as a stimulus to osteogenesis. Ann. Surg. 1920 Jan;71(1):32-9.

5. Amler $\mathrm{MH}$, Johnson $\mathrm{PL}$, Salman I. Histological and histochemical investigation of alveolar socket healing in undisturbed extraction wounds. J Am Dent Assoc. 1960 Jul; 61:32-44.

6. An YH. Mechanical properties of bone. In: An YH, Draughn RA, editors. Mechanical testing of bone and the bone-implant interface. Boca Raton: CRC Press; 2000. p. 41-64.

7. Antunes AA, Oliveira Neto $P$, De Santis E, Caneva M, Botticelli D, Salata LA. Comparisons between Bio-Oss ${ }^{\circledR}$ and Straumann ${ }^{\circledR}$ BoneCeramic in immediate and staged implant placement dogs mandible bone defects. Clin Oral Implants Res. 2013 Feb;24(2):135-42.

8. Aoki H. Science and medical applications of hydroxyapatite. Tokyo: JAAS Press; 1991.

9. Araújo MG, Lindhe J. Socket grafting with the use of autologous bone: an experimental study in the dog. Clin Oral Implants Res. 2011 Jan;22(1):9-13.

10. Arinzeh TL, Peter SJ, Archambault MP, Van Den Bos C, Gordon S, Kraus K, Smith A, Kadiyala S. Allogenic mesenchymal stem cells regenerate bone in a critical-sized canine segmental defect. J Bone Joint Surg Am. 2003 Oct; 85(10):1927-35.

11. Arinzeh TL, Tran T, Mcalary J, Daculsi G. A comparative study of biphasic calcium phosphate ceramics for human mesenchymal stem-cell-induced bone formation. Biomaterials. 2005 Jun; 26(17):3631-8. 
12. Arvidson K, Abdallah BM, Applegate, LA, Baldini N, Cenni E, Gomez-Barrena E, Granchi D, Kassem M, Konttinen YT, Mustafa K, Pioletti DP, Sillat T, FinneWistrand A. Bone regeneration and stem cells. J. Cell Mol Med. 2011 Apr;15(4):718-46

13. Baba S, Inoue,T, Hashimoto Y, Kimura D, Ueda M, Sakai K, Matsumoto N, Hiwa C, Adachi T, Hojo M. Effectiveness of scaffolds with pre-seeded mesenchymal stem cells in bone regeneration--assessment of osteogenic ability of scaffolds implanted under the periosteum of the cranial bone of rats. Dent Mater J. 2010 Nov;29(6):673-81.

14. Badiavas AR, Badiavas EV. Potential benefits of allogeneic bone marrow mesenchymal stem cells for wound healing. Expert Opin Biol Ther. 2011; 11(11):1447-54.

15. Balabanian CACA. Avaliação histométrica e histológica de reparo ósseo do alvéolo dental implantado com látex natural. Tese de Doutorado. Ribeirão Preto: Faculdade de Odontologia de Ribeirão Preto, USP; 2005. 98p.

16. Barone A, Ricci M, Mangano F, Covani U. Morbidity associated with iliac crest harvesting in the treatment of maxillary and mandibular atrophies: a 10-year analysis. J Oral Maxillofac Surg. 2011 Sep;69(9):2298-304.

17. Bartholomew A, Patil S, Mackay A, Nelson M, Buyaner D, Hardy W, Mosca J, Sturgeon C, Siatskas M, Mahmud N, Ferrer K, Deans R, Moseley A, Hoffman $\mathrm{R}$, Devine SM. Mesenchymal stem cells can be genetically modified to secret human erythropoietin in vivo. Hum Gene Ther. 2001 Aug;12(12):1527-41.

18. Bartholomew A, Sturgeon C, Siatskas M, Ferrer K, Mcintosh K, Patil S, Hardy W, Devine S, Ucker D, Deans R, Moseley A, Hoffman R. Mesenchymal stem cells suppress lymphocyte proliferation in vitro and prolong skin graft survival in vivo. Exp Hematol. 2002 Jan;30(1):42-8.

19. Bastos AS, Spin-Neto R Conte Neto N, Gallina K, Boeck-Neto RJ, Marcantonio C, Marcantonio E, Marcantonio Júnior E. Calvarial autogenous bone graft for maxillary ridge and sinus reconstruction for rehabilitation with dental implants. $J$ Oral Implantol. 2012; Apr 9.

20. Beloti MM, Tambasco De Oliveira P, Perri De Carvalho OS, Rosa AL. Seeding osteoblastic cells into a macroporous biodegradable CaP/PLGA scaffold by a centrifugal force. J Biomater Appl. 2009 May;23(6):481-95.

21. Bianco P, Riminucci M, Gronthos S, Robey PG. Bone marrow stem cells: nature, biology, and potential applications. Stem Cells. 2001;19(3):180-92.

22. Blokhuis TJ, Termaat MF, Den Boer FC, Patka P, Bakker FC, Haarman HJ. Properties of calcium phosphate ceramics in relation to their in vivo behavior. $\mathrm{J}$ Trauma. 2000 Jan;48(1):179-86. 
23. Bodde EW, Wolke JG, Kowalski RS, Jansen JA. Bone regeneration of porous beta-tricalcium phosphate (Conduit TCP) and of biphasic calcium phosphate ceramic (Biosel) in trabecular defects in sheep. J Biomed Mater Res A. 2007 Sep;82(3):711-22.

24. Boëck-Neto RJ, Artese L, Piattelli A, Shibli JÁ, Perrotti V, Piccirilli M, Marcantonio EJr. VEGF and MVD expression in sinus augmentation with autologous bone and several graft materials. Oral Dis. 2009 Mar;15(2):148-54.

25. Bombonato-Prado KF, Brentegani LG, Thomazini JÁ, Lachat JJ, LamanoCarvalho TL. Alcohol intake and osseointegration around implants: A histometric and scanning electron microscopy study. Implant Dent. 2004 Sep;13(3):238-44.

26. Bombonato-Prado KF. Efeito do alcoolismo no reparo alveolar de ratos após o implante de uma biocerâmica. Estudo qualitativo e quantitativo em microscopia de luz e eletrônica de varredura. Tese de Doutorado. Ribeirão Preto: Faculdade de Odontologia de Ribeirão Preto, USP; 2002. 109p.

27. Boontheekul T, Mooney DJ. Protein-based signaling systems in tissue engineering. Curr Opin Biotechnol. 2003 Oct;14(5):559-65.

28. Boyne PJ. Current developments with growth factors and bone proteins. Dent Implantol Update. 1999 Apr;10(4):25-7.

29. Burwell RG. A study of homologous cancellous bone combined with autologous red marrow after transplantation to a muscular site. J Anat. 1961;95:613-16.

30. Calixto RFE, Teófilo JM, Brentegani LG, Lamano-Carvalho TL. Alveolar wound healing after implantation with a pool of commercially available bovine bone morphogenetic proteins (BMPs) - A histometric study in rats. Braz Dent J. 2007;18(1):29-33.

31. Calixto RFE. Estudo comparativo do reparo alveolar após implante de uma mistura de BMPs bovinas, de partículas de matriz óssea bovina orgânica e inorgânica e de um vidro bioativo na cavidade de extração dental de rato. Tese de Doutorado. Ribeirão Preto: Faculdade de Odontologia de Ribeirão Preto, USP; 2005. 97p.

32. Cancedda R, Giannoni P, Mastrogiacomo M. A tissue engineering approach to bone repair in large animal models and in clinical practice. Biomaterials. 2007 Oct;28(29):4240-50.

33. Carinci F, Farina A, Zanetti U, Vinci R, Negrini S, Calura G, Laino G, Piattelli A. Alveolar ridge augmentation: A comparative longitudinal study between calvaria and iliac crest bone graft. J Oral Implantol. 2005;31(1):39-45.

34. Carvalho ACP, Okamoto T. Cirurgia Bucal: fundamentos experimentais aplicados à clínica. São Paulo: Médica Panamericana, 1987. 139p. 
35. Carvalho ACP, Okamoto T. Implantes intra-alveolares: considerações sobre estudos experimentais. Rev Assoc Paul Cir Dent. 1978;32(4):273-79.

36. Carvalho PSP, Vasconcelos LW, Pi J. Influence of bed preparation on the incorporation of autogenous bone grafts: a study in dogs. Int $\mathrm{J}$ Oral Maxilofac Implants. 2000 Jul-Aug;15(4):565-70.

37. Castro FS. Avaliação da manutenção da dimensão de rebordo alveolar após enxerto aloplástico de composto ósseo de rícino pós-extração dental em rato, estudo radiográfico e histológico. Dissertação de Mestrado. São Carlos: Escola de Engenharia de São Carlos/ Faculdade de Medicina de Ribeirão Preto/ Instituto de Química de São Carlos, USP; 2006. 76p.

38. Cestari TM, Garlet GP, Granjeiro JM, Taga R. Inflamação e reparo do tecido em resposta a biomateriais. In: Granjeiro JM, Soares GDA, editors. Biomateriais em Odontologia. 1 ed. São Paulo: VM Cultural; 2011. P.129-49.

39. Chang BS, Lee CK, Youn HJ. Osteoconduction at porous hydroxyapatite with various pore configurations. Biomaterials. 2000 Jun;21(12):1291-98.

40. Chapman MW, Rodrigo JJ. Bone grafting, bone graft substitutes and growth factors. In: Chapman MW, editors. Chapman's Orthopaedic Surgery. Lippincott Williams \& Wilkins, 2001.

41. Chappard D, Guillaume B, Mallet R, Pascaretti-Grizon F, Baslé MF, Libouban $H$. Sinus lift augmentation and $\beta$-TCP: a microCT and histologic analysis on human bone biopsies. Micron. 2010 Jun;41(4):321-6.

42. Chen N, Du YF, Guo JL, Zhang SY, Tao J.F. Biologic response to autogenous particulate bone graft and shaped titanium mesh in segmental mandibular defect reconstruction. Int J Oral Maxillofac Implants. 2011 Mar-Apr;26(2):33340.

43. Choi SW, Zhang Y, Xia, Y. Three-dimensional scaffolds for tissue engineering: the importance of uniformity in pore size and structure. Langmuir. 2010 Dec;26(24):19001-6.

44. Cochran DL, Jones A, Heijl L, Mellonig JT, Schoolfield J, King G.N. Periodontal regeneration with a combination of enamel matrix proteins and autogenous bone grafting. J Periodontol. 2003 Sep;74(9):1269-81.

45. Connolly JF. Injectable bone marrow preparations to stimulate osteogenic repair. Clin Orthop Relat Res. 1995 Apr;313:8-18.

46. Cordaro L, Bosshardt DD, Palattella P, Rao W, Serino G, Chiapasco M. Maxillary sinus grafting with Bio-Oss or Straumann Bone Ceramic: histomorphometric results from a randomized controlled multicenter clinical trial. Clin Oral Implants Res. 2008 Aug;19(8):796-803. 
47. Cordaro L, Torsello F, Miuccio MT, Di Torresanto VM, Eliopoulos D. Mandibular bone harvesting for alveolar reconstruction and implant placement: subjective and objective cross-sectional evaluation of donor and recipient site up to 4 years. Clin Oral Implants Res. 2011 Nov;22(11):1320-6.

48. Crespi R, Vinci R, Capparè P, Gherlone E, Romanos GE. Calvarial versus iliac crest for autologous bone graft material for a sinus lift procedure: a histomorphometric study. Int J Oral Maxillofac Implants. 2007 JulAug;22(4):527-32.

49. Cullum PE, Frost DE, Newland TB, Keane TM, Ehler WJ. Evaluation of Hydroxyapatite particles in repair of alveolar clefts in dogs. J Oral Maxallofac Surg. 1998 Apr;46(4):290-6.

50.Daculsi G, Laboux O, Malard O, Weiss P. Current state of the art of biphasic calcium phosphate bioceramics. J Mater Sci Mater Med. 2003 Mar;14(3):195200.

51.Daculsi G, Weiss P, Bouler JM, Gauthier O, Millot F, Aguado E. Biphasic calcium phosphate/hydrosoluble polymer composites: a new concept for bone and dental substitution biomaterials. Bone. 1999 Aug;25(2 supplement):59S$61 S$.

52. Daculsi G. Biphasic calcium phosphate concept applied to artificial bone, implant coating and injectable bone substitute. Biomaterials. 1998 Aug; 19(16):1473-8.

53. Das A, Botchwey E. Evaluation of angiogenesis and osteogenesis. Tissue Eng Part B Rev. 2011 Dec; 17(6):403-14.

54.Davies J. Mechanisms of endosseous integration. International J Prosthodontics. 1998 Sep-Oct; 11(5):391-401.

55. De Coster $\mathrm{P}$, browaeys $\mathrm{H}$, De Bruyn $\mathrm{H}$. Healing of extraction sockets filled with BoneCeramic ${ }^{\circledR}$ prior to implant placement: preliminary histological findings. 2011 Mar;13(1):34-45.

56. De Kok IJ, Susan J, Peter SJ, Archambault M, Van Den Bos C, Kadiyala S, Aukhil I, Cooper LF. Investigation of allogenic mesenchymal stem cell-based alveolar bone formation: preliminary findings. Clin Oral Impl Res. 2003 Aug;14:481-89.

57. De Long WGJr, Einhorn TA, Koval K, Mckee M, Smith W, Sanders R, Watson $\mathrm{T}$. Bone grafts and bone graft substitutes in orthopaedic trauma surgery. A critical analysis. J Bone Joint Surg Am. 2007 Mar;89(3):649-58.

58. De Oliveira PT, Zalzal SF, Irie K, Nanci A. Early expression of bone matrix proteins in osteogenic cell cultures. J Histochem Cytochem. 2003 May;51(5):633-41. 
59. Deppe H, Mücke T, Wagenpfeil S, Hölzle F. Sinus augmentation with intra- vs extraorally harvested bone grafts for the provision of dental implants: clinical long-term results. Quintessence Int. 2012 jun;43(6):469-81.

60. Devine SM, Cobbs C, Jennings M, Bartholomew A, Hoffman R. Mesenchymal stem cells distribute to a wide range of tissues following systemic infusion into nonhuman primates. Blood. 2003 Apr;101(8):2999-3001.

61. Devlin H, Sloan P. Early bone healing events in the human extraction sockets. Int J Oral Maxilofac Surg. 2002 Dec;31(6):641-5.

62. Di Nicola M, Carlo-Stella C, Magni M, Milanesi M, Longoni PD, Matteucci P, Grisanti S, Gianni AM. Human bone marrow stromal cells suppress Tlymphocyte proliferation induced by cellular or nonspecific mitogenic stimuli. Blood. 2002 May;99(10):3838-43.

63. Dietze S, Bayerlein T, Proff P, Hoffmann A, Gedrange T. The ultrastructure and processing properties of Straumann Bone Ceramic and NanoBone. Folia Morphol. (Warsz). 2006 Feb;65(1):63-5.

64. Dinato JC, Polido WD. Implantes Osseointegrados: Cirurgia e Prótese. São Paulo: Artes Médicas; 2004. 550 p.

65.Donos N, Kostopoulos L, Karring T. Alveolar ridge augmentation by autogenous mandibular bone grafts and non-resorbable membranes. Clin Oral Impl Res. 2002 Apr;13(2):185-91.

66. Donovan MG, Dickerson NC, Hanson LJ, Gustafson RB. Maxillary and mandibular reconstruction using calvarial bone grafts and branemark implants: A preliminary report. J Oral Maxillofac Surg. 1994 Jun;52(6):588-94.

67.Dorozhkin SV. Bioceramics of calcium orthophosphates. Biomaterials. 2010 Mar;31(7):1465-85.

68. Dupoirieux L, Costes V, Jammet P, Souyris, F. Experimental study on demineralized bone matrix (DBM) and coral as bone graft substitutes in maxillofacial surgery. Int J Oral Maxilofac Surg. 1994 Dec;23(6):395-8.

69. Ellies LG. Altered sensation following mandibular implant surgery: a retrospective study. J Prosthet Dent. 1992 Oct;68(4):664-71.

70. Ellis III E. Reconstrução cirúrgica dos defeitos maxilares. In: Petterson LJ, editors. Cirurgia Oral e Maxilofacial Contemporânea. Rio de Janeiro: Guanabara Koogan, 2001.

71. Esposito M, Grusovin MG, Coulthard P, Worthington HV. The efficacy of various bone augmentation procedures for dental implants: a Cochrane systematic review of randomized controlled clinical trials. Int J Oral Maxillofac Implants. 2006 Sep-Oct;21(5):696-710. 
72. Fan HS, Ikoma T, Bao CY, Wang HL, Zhang LL, Tanaka J. Surface characteristics and osteoinductivity of biphasic calcium phosphate ceramics with different sintering temperature. Bioceramics. 2006;18:1299-303.

73. Farahpour MR, Sharifi D, B AA, Veshkini A, Soheil A. Radiological evaluation of the effect of biphasic calcium phosphate scaffold (HA+TCP) with 5, 10 and 20 percentage of porosity on healing of segmental bone defect in rabbit radius. Bratisl Lek Listy. 2012;113(9):529-33.

74. Fellah BH, Gauthier O, Weiss P, Chappard D, Layrolle P. Osteogenicity of biphasic calcium phosphate ceramics and bone autograft in a goat model. Biomaterials. 2008 Mar;29(9):1177-88.

75. Feng B, Jinkang Z, Zhen W, Jianxi L, Jiang C, Jian L, Guolin M, Xin D. The effect of pore size on tissue ingrowth and neovascularization in porous bioceramics of controlled architecture in vivo. Biomed Mater. 2011 Feb;6(1):015007.

76. Franceschi RT. Biological approaches to bone regeneration by gene therapy. J Dent Res. 2002 Dec;84(12):1093-103.

77. Frenken JW, Bouwman WF, Bravenboer N, Zijderveld SA, Schulten EA, Ten Bruggenkate CM. The use of Straumann BoneCeramic ina a maxillary sinus floor elevation procedure: a clinical, radiological, histological and histomorphometric evaluation with a 6-month healing period. 2010 Feb;21(2):201-8.

78. Friedenstein AJ, Petrakova KV, Kurolesova AI, Frolova GP. Heterotopic of bone marrow. Analysis of precursor cells for osteogenic and hematopoietic tissues. Transplantation. 1968 Mar;6(2):230-47.

79. Friedenstein AJ, Piatetzky-Shapiro II, Petrakova KV. Osteogenesis in transplants of bone marrow cells. J Embryol Exp Morphol. 1966 Dec;16(3):381-90.

80. Friedmann A, Dard M, Kleber BM, Bernimoulin JP, Bosshardt DD. Ridge augmentation and maxillary sinus grafting with a biphasic calcium phosphate: histologic and histomorphometric observations. Clin Oral Implants Res. 2009 Jul;20(7):708-14.

81. Frost HM. Tetracycline-based histological analysis of bone remodeling. Calcif Tissue Res. 1969;3(3):211-37.

82. Fujikawa K, Sugawara A, Murai S, Nishiyama M, Takagi S, Chow L.C. Histopathological reaction of calcium phosphate cement in periodontal bone defect. Dental Materials Journal. 1995 Jun;14(1):45-57.

83. Fujita R, Yokoyama A, Kawasaki T, Kohgo T. Bone augmentation osteogenesis using hydroxyapatite and beta-tricalcium phosphate blocks. J Oral Maxillofac Surg. 2003a Sep;61(9):1045-53. 
84. Fujita R, Yokoyama A, Nodasaka Y, Kohgo T, Kawasaki T. Ultrastructure of ceramic-bone interface using hydroxyapatite and beta-tricalcium phosphate ceramics and replacement mechanism of beta-tricalcium phosphate in bone. Tissue Cell. 2003b Dec;35(6):427-40.

85. Garcia RD. Estudo do processo evolutivo do reparo ósseo frente ao implante de osso bovino inorgânico e de hidroxiapatita BTCP. Análise microscópica em alvéolos dentários de ratos. Dissertação de Mestrado. Bauru: Faculdade de Odontologia de Bauru, USP; 2007. 168p.

86. Gau CH, Hsieh YD, Shen EC, Lee S, Chiang CY, Fu E. Healing following tooth extraction in cyclosporine-fed rats. Int. J Oral Maxilofac Surg. 2005 Oct;34(7):782-88.

87. Gisep A, Wieling R, Bohner M, Matter S, Schneider E, Rahn B. Resorption patterns of calcium-phosphate cements in bone. J Biomed Mater Res A. 2003 Sep;66(3):532-40.

88. Godbey WT, Hindy SB, Sherman ME, Atala A. A novel use of centrifugal force for cell seeding into porous scaffolds. Biomaterials. 2004 Jun;25(14):2799-805.

89. Goldberg VM, Stevenson S. The biology of bone grafts. Semin Arthroplasty. 1993 Apr;4(2):58-63.

90. Gorustovich AA, Steimetz T, Nielsen FH, Guglielmotti MB. Histomorphometric study of alveolar bone healing in rats fed a boron-deficient diet. Anat Rec. 2008 Apr;291(4):441-7.

91. Goshima J, Goldberg VM, Caplan Al. The osteogenic potential of cultureexpanded rat marrow mesenchymal cells assayed in vivo in calcium phosphate ceramic blocks. Clin Orthop Relat Res. 1991 Jan;262:298-311.

92. Griffin MD, Ritter T, Mahon BP. Immunological aspects of allogeneic mesenchymal stem cell therapies. Hum Gene Ther. 2010 Dec;21(12):1641-55.

93. Gross JS. Bone grafting materials for dental applications: A practical guide. Compend Contin Educ Dent. 1997 Oct;18(10):1013-34.

94. Grundel RE, Chapman MW, Yee T, Moore DC. Autogenic bone marrow and porous biphasic calcium phosphate ceramic for segmental bone defects in the canine ulna. Clin Orthop. 1991 May;266:244-58.

95. Gutta R, Waite PD. Outcomes of calvarial bone grafting for alveolar ridge reconstruction. Int J Oral Maxillofac Implants. 2009 Jan-Feb;24(1):131-6.

96. Habibovic $P$, Yuan $H$, Van Den Doel $M$, Sees TM, Van Blitterswijk CA, De Groot K. Relevance of osteoinductive biomaterials in critical-sized orthotopic defect. J Orthop Res. 2006 May;24(5):867-76. 
97. Hannink G, Arts JJ. Bioresorbability, porosity and mechanical strength of bone substitutes: what is optimal for bone regeneration? Injury. 2011 Sep;42(2 Suppl):S22-5.

98. Hasegawa T, Miwa M, Sakai Y, Niikura T, Lee SY, Oe K, Iwakura T, Kurosaka $\mathrm{M}$, Komori T. Efficient cell-seeding into scaffolds improves bone formation. $\mathrm{J}$ Dent Res. 2010 Aug;89(8):854-9.

99. Hench II, Wilson J. Surface-active biomaterials. Science. 1984 Nov 9;226(4675):630-6.

100. Hernigou P, Poignard A, Beaujean F, Rouard H. Percutaneous autologous bone-marrow grafting for nonunions. Influence of the number and concentration of progenitor cells. J Bone Joint Surg Am. 2005 Jul;87(7):1430-7.

101. Holtorf HL, Datta N, Jansen JA, Mikos AG. Scaffold mesh size affects the osteoblastic differentiation of seeded marrow stromal cells cultured in a flow perfusion bioreactor. J Biomed Mater Res A. 2005 Aug;74(2):171-80.

102. Horowitz RA, Mazor Z, Miller RJ, Krauser J, Prasad HS, Rohrer MD. Clinical evaluation alveolar ridge preservation with a beta-tricalcium phosphate socket graft. Compend Contin Educ Dent. 2009 Nov-dec;30(9):588-90.

103. Hulbert SF, Young FA, Mathews RS, Klawitter JJ, Talbert CD, Stelling FH. Potential of ceramic materials as permanently implantable skeletal prostheses. J Biomed Mater Res. 1970 Sep;4(3):433-56.

104. Itala Al, Ylanen HO, Ekholm C, Karlsson KH, Aro HT. Pore diameter of more than 100 microm is not requisite for bone ingrowth in rabbits. J Biomed Mater Res. 2001;58(6):679-83.

105. Ito K, Yamada Y, Naiki T, Ueda M. Simultaneous implant placement and bone regeneration around dental implants using tissue-engineered bone with fibrin glue, mesenchymal stem cells and platelet-rich plasma. Clin Oral Impl Res. 2006 Oct;17(5):579-586.

106. Iturriaga MTM, Ruiz CC. Maxillary sinus reconstruction with calvarium bone grafts and endosseous implants. J Oral Maxillofac Surg. 2004 Mar;62(3):34447.

107. Jafarian $M$, Eslaminejad MB, Khojasteh A, Abbas FM, Dehghan MM, Hassanizadeh R, Houshmand B. Marrow-derived mesenchymal stem cellsdirected bone regeneration in the dog mandible: a comparison between biphasic calcium phosphate and natural bone mineral. Oral Surg Oral Med Oral Pathol Oral Radiol Endod. 2008 May;105(5):14-24.

108. Jahangiri L, Devlin H, Ting K, Nishimura I. Current perspectives in residual ridge remodeling and its clinical implications: a review. J Prosthet Dent. 1998 Aug;80(2):224-37. 
109. Janicki $P$, Schmidmaier $G$. What should be the characteristics of the ideal bone graft substitute? Combining scaffolds with growth factors and/or stem cells. Injury. 2011 Sep;42(2 Suppl):S77-81.

110. Jensen SS, Broggini N, Hjørting-Hansen E, Schenk R, Buser D. Bone healing and graft resorption of autograft, anorganic bovine bone and $\beta$-tricalcium phosphate. A histologic and histomorphometric study in the mandible of minipigs. Clin Oral Impl Res. 2006 Jun;17(3):237-43.

111. Jin QM, Takita H, Kohgo T, Atsumi K, Itoh H, Kuboki Y. Effects of geometry of hydroxyapatite as a cell substratum in BMP-induced ectopic bone formation. J Biomed Mater Res. 2000 Sep;51(3):491-9.

112. Johansen JR. Repair of the post-extraction alveolus in the Wistar rat: a histologic and autoradiographic study. Acta Odontol Scand. 1970 Aug;28(4):441-61.

113. Junqueira LCU, Careniro J. Tecido ósseo. In: Junqueira LCU, Careniro J, editors. Histologia Básica: Texto e atlas. São Paulo: Guanabara Koogan editora; 2008. p. 11- 26.

114. Kadiyala S, Jaiswal N, Bruder SP. Culture-expanded, boné marrow-derived mesenchymal stem cells can regenerate a critical-size segmental bone defect. Tissue Eng. 1997;3:173-85.

115. Karageorgiou V, Kaplan D. Porosity of 3D biomaterial scaffolds and osteogenesis. Biomaterials. 2006 Sep;26(27):5474-91.

116. Kasten $P$, Luginbühl $R$, Van Griensven $M$, Barkhausen $T$, Krettek $C$, Bohner $\mathrm{M}$, Bosch $\mathrm{U}$. Comparison of human bone marrow stromal cells seeded on calcium-deficient hydroxyapatite, beta-tricalcium phosphate and demineralized bone matrix. Biomaterials. 2003 Jul:24(15):2593-603.

117. Kasten P, Vogel J, Luginbühl R, Niemeyer P, Weiss S, Schneider S, Kramer $M$, Leo A, Richter W. Influence of Platelet-Rich Plasma on Osteogenic Differentiation of Mesenchymal Stem Cells and Ectopic Bone Formation in Calcium Phosphate Ceramics. Cells Tissues Organs. 2006;183(2):68-79.

118. Khan SN, Cammisa FPJr, Sandhu HS, Diwan AD, Girardi FP, Lane JN. The biology of bone grafting. J Am Acad Orthop Surg. 2005 Jan-Feb;13(1):77-86.

119. Khoury F. Biologia e fisiologia do leito do implante a partir do enxerto. In: Khoury F, Hanser T, Khoury C, editors et al. Aumento ósseo em implantodontia. São Paulo: Quitessence editora; 2011. p.11- 26.

120. Kitsugi T, Yamamuro T, Nakamura T, Oka M. Transmission electron microscopy observations at the interface of bone and four types of calcium phosphate ceramics with different calcium/phosphorus molar ratios. Biomaterials. 1995 Sep;16(14):1101-7. 
121. Komlev VS, Peyrin F, Mastrogiacomo M, Cedola A, Papadimitropoulos A, Rustichelli F, Cancedda R. Kinetics of in vivo bone deposition by bone marrow stromal cells into porous calcium phosphate scaffolds: an X-ray computed microtomography study. Tissue Eng. 2006 Dec;12(12):3449-58.

122. Krieger S. Biocerâmicas. Universidade de São Paulo; 2003.

123. Krzymanski G, Kalezak M, Wiktor-Jedrzejczak W. The use of bone-marrow derived fibroblastoid cells and fresh bone marrow in the treatment of bone defects: an experimental study. Int J Oral Maxillofac Surg. 1997 Feb;26(1):5560 .

124. Kuboki Y, Jin Q, Kikuchi M, Mamood J, Takita H. Geometry of artificial ECM: sizes of pores controlling phenotype expression in BMP-induced osteogenesis and chondrogenesis. Connect Tissue Res. 2002;43(2-3):529-34.

125. Kuhne J, Bartl R, Frisch B, Hammer C, Jansson V, Zimmer M. Bone formation in coralline hydroxyapatite. Effects of pore size studied in rabbits. Acta Orthop Scand. 1994 Jun;65(3):246-52.

126. Kumar V, Abbas A, Fausto $N$. Tecido de renovação e reparações: Regeneração, cicatrização e fibrose. In: Kumar V, Abbas A, Fausto N, editors. Patologia - Bases patológicas das doenças. Rio de Janeiro: Elsevier; 2005. p. 91-124.

127. Kurita K, Hashimoto Y, Takei T, Kawai T, Hayakwa T. Changes in collagen types during the healing of rabbit tooth extraction wounds. J Dent Res. 1985 Jan;64(1):28-32.

128. Kutkut A, Andreana S, Kim HL, Monaco EJr. Extraction socket preservation graft before implant placement with calcium sulfate hemihydrate and plateletrich plasma: a clinical and histomorphometric study in humans. J Periodontol. 2012 Apr;83(4):401-9.

129. Lacerda SA, Lanzoni JF, Bombonato-Prado KF, Campos AA, Prata CA, Brentegani LG. Osteogenic potential of autogenous bone associated with bone marrow osteoblastic cells in bony defects: a histomorphometric study. Implant Dent. 2008 Dec;18(6):521-9.

130. Lacerda SA, Matuoka RI, Macedo RM, Petenusci SO, Campos AA, Brentegani LG. Osteointegration of autogenous bone graft associated with osteoblastic cells under treatment with caffeine. Implant Dent. 2011 Oct;20(5):369-73.

131. Lamano-Carvalho TL, Brentegani LG, Bombonato KF. Histometric analysis of rat alveolar wound healing. Braz Dent J. 1997;8(1):9-12.

132. Langer R. Tissue engineering. Mol Ther. 2000 Jan;1(1):12-5. 
133. Langstaff S, Sayer M, Smith TJN, Pugh SM. Resorbable bioceramics based on stabilized calcium phosphates. Part II: evaluation of biological response. Biomaterials. 2001 Jan;22(2):135-50.

134. Laurencin CT, Chapter I. Bone graft and bone graft substitutes a brief history. In: LAURENCIN CT, editors., Bone graft substitute. ASTM International; 2004.

135. Lecomte A, Gautier H, Bouler JM, Gouyette A, Pegon Y, Daculsi G, Merle C. Biphasic calcium phosphate: a comparative study of interconnected porosity in two ceramics. J. Biomed. Mater. Res. B Appl. Biomater. 2008 Jan;84(1):1-6.

136. LeGeros RZ, Lin S, Rohanizadeh R, Mijares D, LeGeros JP. Biphasic calcium phosphate bioceramics: preparation, properties and applications. J Mater Sci Mater Med. 2003 Mar;14(3):201-9.

137. LeGeros RZ. Calcium phosphate-based osteoinductive materials. Chem Rev. 2008 Nov;108(11):4742-53.

138. LeGeros RZ. Properties of osteoconductive biomaterials: calcium phosphates. Clin Orthop Relat Res. 2002 Feb;395:81-98.

139. Li X, Liu H, Niu X, Fan Y, Feng Q, Cui FZ, Watari F. Osteogenic differentiation of human adipose-derived stem cells induced by osteoinductive calcium phosphate ceramics. J Biomed Mater Res B Appl Biomater. 2011 Apr;97(1):109.

140. Li Z, Kawashita M. Current progress in inorganic artificial biomaterials. J Artif Organs. 2011 Sep;14(3):163-170.

141. Li Z, Li ZB. Repair of mandible defect with tissue engineering bone in rabbits. ANZ J Surg. 2005 Nov;75(11):1017-21.

142. Lin $\mathrm{H}$. The self-renewing mechanism of stem cells in the germ line. Curr Op Cell Biol. 1998 Dec;10(6):687-93.

143. LIn WL, Mcculollogh CAG, Cho MI. Differentiation of periodontal ligament fibroblasts into osteoblasts during socket healing after tooth extraction in the rat. Anat Rec. 1994 Dec;240(4):492-506.

144. Lindgren C, Mordenfeld A, Hallman M. A prospective 1-year clinical and radiographic study of implants placed after maxillary sinus floor augmentation with synthetic biphasic calcium phosphate or deproteinized bovine bone. Clin Implant Dent Relat Res. 2012 Mar;14(1):41-50.

145. Lindhe J, Karring T, Lang NP. Tratado de Periodontia Clínica e Implantologia Oral. 4th ed. Rio de Janeiro: Guanabara Koogan; 2005. 1013 p.

146. Liu G, Zhao L, Cui L, Liu W, Cao Y. Tissue engineered bone formation using human bone marrow stromal cells and novel b-tricalcium phosphate. Biomed Mater. 2007 Jun;2(2):78-86. 
147. Livingston T, Ducheyne $P$, Garino J. In vivo evaluation of a bioactive scaffold for bone tissue engineering. J Biomed Mater Res. 2002 Oct;62(1):1-13.

148. Lobo SE, Arinzeh LT. Biphasic calcium phosphate ceramics for bone regeneration and tissue engineering applications. Materials. 2010;3:815-26.

149. Lode A, Bernhardt A, Gelinsky M. Cultivation of human bone marrow stromal cells on three-dimensional scaffolds of mineralized collagen: influence of seeding density on colonization, proliferation and osteogenic differentiation. $\mathrm{J}$ Tissue Eng Regen Med. 2008 Oct;2(7):400-7.

150. Luize DS, Bosco AF, Bonfante S, Almeida JM. Influence of ovariectomy on healing of autogenous bone block grafts in the mandible: a histomorphometric study in an aged rat model. Int J Oral Maxilofac Implants. 2008 MarApr;23(2):207-14.

151. Macedo RM, Brentegani LG, Lacerda SA. Effects of Caffeine on Bones of Osteoporotic Rats. J Caffeine Res. 2012;2(3):140-5.

152. Machado GJ, Dias SM, Bosco AF, Okamoto T, Bedran De Castro JC, Dornelles RC. Action of nicotine and ovariectomy on bone regeneration after tooth extraction in rats. J Oral Maxillofac Surg. 2010 Nov;68(11):2675-81.

153. Magalhães AEO, Okamoto T, Barroso JS. Influência da fratura da crista óssea alveolar no processo de reparo de feridas de extração dental: estudo histológico em ratos. Rev Assoc Paul Cir Dent. 1982;36(2):203-12.

154. Mandelbaum SH. Cicatrização: conceitos atuais e recursos auxiliares - parte I. An. Bras. Dermatol. 2003;78(4):393-410.

155. Maniatopolous $\mathrm{C}$, Sodek J, Mekcher AH. Bone formation in vitro by stromal cells obtained from marrow of young adults. Cell Tissue Res. 1988 Nov;254(2):317-30.

156. Manso MC, Lang RD. Enxerto ósseo retro-molar "onlay" para restauração ideal do contorno do rebordo alveolar. Rev Bras Implant. 1997;5(5):7-14.

157. Mardas N, Chadha V, Donos N. Alveolar ridge preservation with guided bone regeneration and a synthetic bone substitute or a bovin-derived xenograft: a randomized, controlled clinical trial. Clin Oral Implants Res. 2010 Jul;21(7):688-98.

158. Mardas N, D'Aiuto F, Mezzomo L, Arzoumanidi M.; Donos N. Radiographic alveolar bone changes following ridge preservation with two different biomaterials. Clin Oral Implants Res. 2011 Apr;22(4):416-23.

159. Marei MK, Nouh SR, Saad MM, Ismail NS. Preservation and regeneration of alveolar bone by tissue-engineered implants. Tissue Eng. 2005 May-Jun;11(5$6): 751-67$. 
160. Matsushima A, Kotobuki N, Tadokoro M, Kawate K, Yajima H, Takakura Y, Ohgushi $\mathrm{H}$. In vivo osteogenic capability of human mesenchymal cells cultured on hydroxyapatite and on beta-tricalcium phosphate. Artif Organs. 2009 Jun;33(6):474-81.

161. McAllister BS, HaghighaTK, Prasad HS, Rohrer MD. Histologic evaluation of recombinant human platelet-derived growth factor-BB after use in extraction socketdefects: a case series. Int J Periodontics Restorative Dent. 2010 Aug;30(4):365-73.

162. Melo A. Estudo da reparação do alvéolo dental de ratos wistar preenchido com osso autógeno particulado após exodontia. Dissertação de Mestrado. São Paulo: Instituto de Ciências Biomédicas, USP; 2007. 116p.

163. Mendes RM, Silva GA, Lima M, Calliari MV, Almeida AP, Alves JB, Ferreira AJ. Sodium hyaluronate accelerates the healing process in tooth sockets of rats. Arch Oral Biol. 2008 Dec;53(12):1155-62.

164. Minichetti JC, D'Amore JC, Hong AYJ, Cleveland DB. Human histological analysis of mineralized bone allograft (puros) placement before implant surgery. J Oral Implantol. 2004;30(2):74-82.

165. Minuth WW, Sittinger M, Kloth S. Tissue engineering: generation of differentiated artificial tissues for biomedical applications. Cell Tissue Res. 1998 Jan;29(1):1-11.

166. Miranda SC, Silva GA, Hell RC, Martins MD, Alves JB, Goes AM. Threedimensional culture of rat BMMSCs in a porous chitosan-gelatin scaffold: A promising association for bone tissue engineering in oral reconstruction. Arch Oral Biol. 2011 Jan;56(1):1-15.

167. Misch CE. Implantes Dentários Contemporâneos. 2nd. ed. São Paulo: Editora Santos; 2006. 685p.

168. Misch CM. Maxillary autogenous bone grafting. Oral Maxillofac Surg Clin North Am. 2011 May;23(2):229-38.

169. Misiek D, Kent J, Carr R. Soft tissue responses to hydroxyapatite particles of different shapes. J Oral Maxillofac Surg. 1984 Mar;42(3):150-60.

170. Miyamoto I, Funaki K, Yamauchi K, Kodama T, Takahashi T. Alveolar ridge reconstruction with titanium mesh and autogenous particulate bone graft: computed tomography-based evaluations of augmented bone quality and quantity. Clin Implant Dent Relat Res. 2012 Apr;14(2):304-11.

171. Monolagas SC, Jilka RL. Mechanisms of disease. Bone marrow, cytokines and bone remodeling- emerging insights into the pathophysiology of osteoporosis. New England J Med. 1995 Feb 2;332(5):305-11. 
172. Moore WR, Graves SE, Bain GI. Synthetic bone graft substitutes. ANZ J Surg. 2001 Jun;71(6):354-61.

173. Morjaria KR, Wilson R, Palmer RM. Bone Healing after Tooth Extraction with or without an Intervention: A Systematic Review of Randomized Controlled Trials. Clin Implant Dent Relat Res. 2012 Mar;8.

174. Morse A. Formic acid-sodium citrate decalcification and butyl deydratation of teeth and bone for sectioning in paraffin. J Dent Res. 1945;24:143.

175. Murphy JM, Fink DJ, Hunziker EB, Barry FP. Stem cell therapy in a caprine model osteoarthritis. Arthritis Rheum. 2003 Dec;48(12):3464-74.

176. Muschler GF, Midura RJ, Nakamoto C. Practical modeling concepts for connective tissue stem cell and progenitor compartment kinetics. J Biomed Biothecnol. 2003;2003(3):170-93.

177. Muschler GF, Midura RJ. Connective tissue progenitor: Practical concepts for clinical applications. Clin Orthop Relat Res. 2002 Feb;395:66-80.

178. Nade S, Armstrong L, McCartney E, Baggaley B. Osteogenesis after bone and bone marrow transplantation. The ability of ceramic materials to sustain osteogenesis from transplanted bone marrow cells: preliminary studies. Clin Orthop Relat Res. 1983 Dec;181:255-63.

179. Nahles S, Nack C, Gratecap K, Lage H, Nelson JJ, Nelson K. Bone physiology in human grafted and non-grafted extraction sockets - an immunohistochemical study. Clin Oral Implants Res. 2012 Mar;30.

180. Nair MB, Babu SS, Varma HK, John A. A triphasic ceramic-coated porous hydroxyapatite for tissue engineering application. Acta Biomater. 2008 Jan;4(1):173-81.

181. Nery EB, Lynch KL, Hirthe WM, Mueller KH. Bioceramic implants in surgically produced infrabony defects. J Periodontol. 1975 Jun;46(6):328-47.

182. Nery EB, Lynch KL, Rooney GE. Alveolar ridge augmentation with tricalcium phosphate ceramic. J Prosthet Dent. 1978 Dec;40(6):668-75.

183. Ohgushi H, Caplan Al. Stem cell technology and bioceramics: from cell to gene engineering. J Biomed Mater Res. 1999;48(6):913-27.

184. Ohta K, Monma H, Takahashi S. Adsorption characteristics of proteins on calcium phosphates using liquid chromatography. J Biomed Mater Res. 2001 Jun 5;55(3):409-14.

185. Okamoto T, Alves-Rezende MCR, Cláudio CC, Rodrigues TS, Okamoto R. Effects of tissucol and epsilon aminocaproic acid in the healing process following dental extraction in dehydrated rats. Braz Oral Res. 2006 JanMar;20(1):33-9. 
186. Okamoto T, Okamoto R, Alves-Rezende MC, Gabrielli MF. Interference of the blood clot on granulation tissue formation after tooth extraction. Histomorphological study in rats. Braz Dent J. 1994;5(2):85-92.

187. Okamoto T, Russo MC. Wound healing following tooth extraction. Rev. Fac Odont Araçatuba. 1973;2(2):153-62.

188. Orr TE, Villars PA, Mitchell SL, Hsu HP, Spector M. Compressive properties of cancellous bone defects in a rabbit model treated with particles of natural bone mineral and synthetic hydroxyapatite. Biomaterials. 2001 Jul;22(14):1953-59.

189. Orsini M, Orsini G, Benlloch D, Aranda JJ, Lazaro P, Sanz M, De Luca M, Piatelli A. Comparison of calcium sulfate and autogenous bone graft to bioabsorbable membrane plus autogenous bone graft in the treatment of intrabony periodontal defects: a splint-mouth study. J Periodontol. 2001 Mar;72(3):296-302.

190. Osborn JF, Newesley H. Dynamic aspects of the implant bone interface. In: HEIMKE, G, editors. Dental Implants-Materials and Systems. Munich: Carl Hanser; 1980. p. 111-23.

191. Owen M. Lineage of osteogenic cells and their relationship to the stromal system. Bone Miner Res. 1985;3:1-25.

192. Ozaki W, Buchman SR. Volume maintenance of onlay bone grafts in the craniofacial skeleton: micro-architecture versus embryologic origin. Plast Reconstr Surg. 1998 Aug;102(2):291-9.

193. Paleckis LGP. Reparação inicial de enxertos ósseos autógenos em blocos ou em partículas: estudo microscópico em cães. Tese de Doutorado. Araçatuba: Universidade Estadual Paulista, Faculdade de Odontologia de Araçatuba; 2004. 121p.

194. Parfitt AM. The cellular basis of bone remodeling: The quantum concept reexamined in the light of recent advances in the cell biology of bone. Calcif Tissue Int. 1984;36(suppl 1):S37-45.

195. Patel K, Mardas N, Donos N. Radiographic and clinical outcomes of implants placed in ridge preserved sites: a 12-month post-loading follow-up. Clin Oral Implants Res. 2012 Jun;3.

196. Pedrosa CSG, Alves GG, Granjeiro JM, Roedel MBG, Oliveira RC, Zambuzzi WF. Avaliação da compatibilidade biológica de biomateriais - ensaios in vitro. Parte 1. In: Granjeiro JM, Soares GDA, editors. Biomateriais em Odontologia. 1st ed. São Paulo: VM Cultural; 2011. P. 151-60.

197. Peer LA. The fate of autogenous human bone grafts. Brit J Plast Surg. 1951 Jan;3(4):233-43. 
198. Pelegrine AA, Da Costa CE, Correa ME, Marques JFJr. Clinical and histomorphometric evaluation of extraction sockets treated with an autologous bone marrow graft. Clin Oral Implants Res. 2010 May;21(5):535-42.

199.Peng J, Wen C, Wang A, Wang Y, Xu W, Zhao B, Zhang L, Lu S, Qin L, Guo $Q$, Dong L, Tian J. Micro-CT-based bone ceramic scaffolding and its performance after seeding with mesenchymal stem cells for repair of loadbearing bone defect in canine femoral head. J Biomed Mater Res B Appl Biomater. 2011 Feb;96(2):316-25.

200. Pereira MC, Zecchin KG, Campagnoli EB, Jorge J. Ovariectomy delays alveolar wound healing after molar extractions in rats. J. Oral Maxillofac Surg. 2007;65:2248-53.

201. Petrovic V, Zivkovic $P$, Petrovic D, Stefanovic V. Craniofacial bone tissue engineering. Oral Surg Oral Med Oral Pathol Oral Radiol. 2012 Sep;114(3):1-9.

202. Pittenger MF, Mackay AM, Beck SC, Jaiswal RK, Douglas R, Mosca JD, Moorman MA, Simonetti DW, Craig S, Marshak DR. Multilineage potential of adult human mesenchymal stem cells. Science. 1999 Apr 2;284(5411):143-7.

203. Planka L, GAL P, Kecova H, Klima J, Hlucilova J, Filova E, Amler E, Krupa P, kren L, Srnec R, Urbanova L, Lorenzova J, Necas A. Allogeneic and autogenous transplantations of MSCs in treatment of the physeal bone bridge in rabbits. BMC Biotechnol. 2008 Sep;12(8):70-7.

204.Prata CA, Lacerda SA, Brentegani LG.; Autogenous bone graft associated with enamel matrix proteins in bone repair. Implant Dent. 2007 Dec;16(4):41320.

205. Prata CA. Reparação óssea alveolar após implante de uma combinação de proteínas derivadas da matriz de esmalte e osso autógeno. Estudo histométrico. Dissertação de Mestrado. Ribeirão Preto: Faculdade de Odontologia de Ribeirão Preto, USP; 2005. 98p.

206. Reddy S, Wasnik S, Guha A, Kumar JM, Sinha A, Singh S. Evaluation of nano-bipahsic calcium phosphate ceramics for bone tissue engineering applications: In vitro and preliminary in vivo studies. J Biomater Appl. 2013 Jan;27(5):565-75.

207. Reis-Filho CR, Silva ER, Martins AB, Pessoa FF, Gomes PV, De Araújo MS, Miziara MN, Alves JB. Demineralized human dentine matrix stimulates the expression of VEGF and accelerates the bone repair in tooth sockets of rats. Arch Oral Biol. 2012 May;57(5):469-76.

208. Rickert D, Sauerbier S, Nagursky H, Menne D, Vissink A, Raghoebar GM. Maxillary sinus floor elevation with bovine bone mineral combined with either autogenousbone or autogenous stem cells: a prospective randomized clinical trial. Clin Oral Implants Res. 2011 Mar;22(3):251-8. 
209. Ripamonti $U$, The morphogenesis of bone in replicas of porous hydroxyapatite obtained from conversion of calcium carbonate exoskeletons of coral. J Bone Joint Surg Am. 1991 Jun;73(5):692-703.

210. Rodrigues Luvizuto E, Mônica Dias S, Chiantelli Cláudio-Coutinho C, Alves Machado L, Rangel Garcia-Júnior I, Okamoto T, Okamoto R. Temporal localization of osteocalcin protein during healing of tooth extraction sockets in rats. Minerva Stomatol. 2010 Jun;59(6):355-61.

211. Roh JD, Nelson GN, Udelsman BV, Brennan MP, Lockhart B, Fong PM, Lopez-Soler RI, Saltzman WM, Breuer CK. Centrifugal seeding increases seeding efficiency and cellular distribution of bone marrow stromal cells in porous biodegradable scaffolds. Tissue Eng. 2007 Nov;13(11):2743-9.

212. Rosa AL, Beloti MM, Van Noort R. Osteoblastic differentiation of cultured rat bone marrow cells on hydroxyapatite with different surface topography. Dental Materials. 2003 Dec;19(8):768-772.

213. Rosa AL, Brentegani LG, Grandini AS. Hydroxyapatite and tricalcium phosphate implants in the dental alveolus of rats. A histometric study. Braz Dent J. 1995;6(2):103-9.

214. Salama R, Weissman SL. The clinical use of combined xenografts of bone and autologous red marrow. J Bone Joint Surg. 1978 Feb;60(1):111-5.

215. Salata LA, Rasmusson L, Kahnberg KE. Effects of a mechanical barrier on the integration of cortical onlay bone grafts placed simultaneously with endosseous implant. Clin Implant Dent Relat Res. 2002;4(2):60-68.

216. Salvato G, Agliardi E. Calvarial bone grafts in severe maxillary atrophy: Preprosthetic surgery with sedation. Implant Dent. 2007 Dec;16(4):356-61.

217. Sanada JT, Canova GC, Cestari TM, Taga EM, Taga R. et al. Análise histológica, radiográfica e do perfil de imunoglobulinas após implantação de enxerto de osso esponjoso bovino desmineralizado em bloco em músculo de ratos. J Appl Oral Sci. 2003;11(3):209-15.

218. Santos EA, Barreira-Pinto VB. Materiais cerâmicos. In: Granjeiro JM, Soares GDA. Biomateriais em Odontologia. 1st ed. São Paulo: VM Cultural; 2011. p. 57-68.

219. Santos-Pinto R. Mineralização no processo de reparo em feridas de extração dental em cães. Estudo histológico, radiográfico e microscópio. 1964. Tese de LivreDocência. Araçatuba: Faculdade de Odontologia de Araçatuba, UNESP; 1964.

220. Sbordone C, Toti P, Guidetti F, Califano L, Santoro A, Sbordone L. Volume changes of iliac crest autogenous bone grafts after vertical and horizontal alveolar ridge augmentation of atrophic maxillae and mandibles: a 6-year computerized tomographic follow-up. J Oral Maxillofac Surg. 2012a Nov;70(11):2559-65. 
221. Sbordone C, Toti $P$, Guidetti F, Califano L, Bufo P, Sbordone L. Volume changes of autogenous bone after sinus lifting and grafting procedures: A 6-year computerized tomographic follow-up. J Craniomaxillofac Surg. 2012b Oct;17.

222. Schmitt CM, Doering H, Schmidt T, Lutz R, Neukam FW, Schlegel KA.

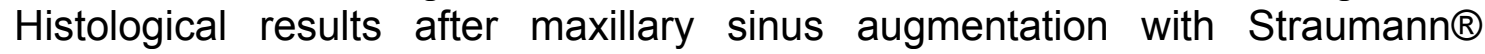
BoneCeramic, Bio-Oss $®$, Puros $®$ and autologous bone. A randomized controlled clinical trial. Clin Oral Implants Res. 2012;13.

223. Seebach C, Schultheiss J, Wilhelm K, Frank J, Henrich D. Comparison of six bone-graft substitutes regarding to cell seeding efficiency, metabolism and growth behavior of human mesenchymal stem cells (MSC) in vitro. Injury. 2010 Jul;41(7):731-8.

224. Shayesteh YS, Khojasteh A, Soleimani M, Alikhasi M, Khoshzaban A, Ahmadbeigi N. Sinus augmentation using human mesenchymal stem cells loaded into a beta-tricalcium phosphate/hydroxyapatite scaffold. Oral Surg Oral Med Oral Pathol Oral Radiol Endod. 2008 Aug;106(2):203-9.

225. Shi H, Ma J, Zhao N, Chen Y, Liao Y. Periodontal regeneration in experimentally-induced alveolar bone dehiscence by an improved porous biphasic calcium phosphate ceramic in beagle dogs. J Mater Sci Mater Med. 2008 Dec;19(12):3515-24.

226. Shiratori K, Matsuzaka K, Koike Y, Murakami S, Shimono M, Inoue T. Bone formation in beta-tricalcium phosphate-filled bone defects of the rat femur: morphometric analysis and expression of bone related protein mRNA. Biomed Res. 2005 Apr;26(2):51-9.

227. Shojl K, Ohtsuka-Isoya M, Horiuchi $H$, Shinoda $H$. Bone mineral density of alveolar bone in rats during pregnancy and lactation. J Periodontol. 2000 Jul;71(7):1073-8.

228. Shyng YC, Devlin H, Riccardi D, Sloan P. Expression of cartilage-derived retinoic acid-sensitive protein during healing of the rat tooth-extraction socket. Arch Oral Biol. 1999 Sep;44(9):751-7.

229. Siegel S. Estatística não paramétrica para as ciências do comportamento. São Paulo: Mc Graw-Hill; 1975.

230. Silva AM, Souza WM, Souza NT, Koivisto MB, Barnabé PA, Poló TS. Filling of extraction sockets with autogenous bone in cats. Acta Cir Bras. 2012 Jan;27(1):82-7.

231. Silva RC, Joly JC, Carvalho PFM. Implantes imediatos com e sem retalho: benefícios e limitações biológicas. In: Joly JC, Carvalho PFM, Silva RC, editors. Reconstrução tecidual estética. Procedimentos plásticos e regenerativos periodontais e peri-implantares. 1st ed. São Paulo: Artes Médicas editora; 2010. P. 453-87. 
232. Silva RV, Camilli JA. Repair of bone defects treated with autogenous bone graft and low-power laser. J Craniofac Surg. 2006 Mar;17(2):297-301.

233. Soares GDA, Granjeiro JM. Conceitos básicos de ciência e engenharia de materiais. Introdução à seleção de biomateriais. In: Granjeiro JM, Soares GDA. Biomateriais em Odontologia. 1st ed. São Paulo: VM Cultural; 2011. p. 21-29.

234. Suh H, Han DW, Park JC, Lee DH, Lee WS, Han CD. A bone replaceable artificial bone substitute: Osteoinduction by combining with bone inducing agent. Artif Organs. 2001 Jun;25(6):459-66.

235. Tadjoedin ES, De Lange GL, Lyaruu DM, Kuiper L, Burger EH. High concentration of bioactive glass material (BioGram) vs. autogenous bone for sinus floor elevation. Histomorphometrical observations on three split mouth clinical cases. Clin Oral Impl Res. 2002 Aug;13(14):428-36.

236. Takyia CM, Granjeiro JM, Maia MDC. Avaliação da compatibilidade biológica de biomateriais - ensaio in vivo. In: Granjeiro JM. Soares, GDA, editors. Biomateriais em Odontologia. 1st ed. São Paulo: VM Cultural; 2011. 167-177.

237. Teófilo JM, Giovanini GS, Fracon RN, Lamano T. Histometric study of alveolar bone healing in rats treated with the nonsteroidal anti-inflammatory drug nimesulide. Implant Dent. 2011 Apr;20(2):7-13.

238. Touzet S, Ferri J, Wojcik, T, RAOUL G. Complications of calvarial bone harvesting for maxillofacial reconstructions. J. Craniofac. Surg. 2011 Jan;22(1):178-81.

239. Trojani C, BoukhechbA F, Scimeca JC, Vandenbos F, Michiels JF, Daculsi G, Boileau P, Weiss P, Carle GF, Rochet N. Ectopic bone formation using an injectable biphasic calcium phosphate/Si-HPMC hydrogel composite loaded withundifferentiated bone marrow stromal cells. Biomaterials. 2006 Jun:27(17):3256-64.

240. Tsuruga E, Takita H, Itoh H, Wakisaka $\mathrm{Y}$, Kubokl $\mathrm{Y}$. Pore size of porous hydroxyapatite as the cell-substratum controls BMP-induced osteogenesis. J Biochem. 1997 Feb;121(2):317-24.

241. Urist MR, Mikulski A, Lietze A. Solubilized and insolubilized bone morphogenetic protein. Proc Natl Acad Sci USA. 1979 Apr;76(4):1828-32.

242. Urist MR. Bone formation by autoinduction. Science. 1965 Nov 12;150(3698):893-9.

243. Vacanti CA, Bonassar LJ. An overview of tissue engineered bone. Clin Orthop Relat Res. 1999 Oct;(367 suppl):S375-81. 
244. Vahabi S, Amirizadeh N, Shokrgozar MA, Mofeed R, Mashhadi A, Aghaloo M, Sharifi D, Jabbareh L. A comparison between the efficacy of Bio-Oss, hydroxyapatite tricalcium phosphate and combination of mesenchymal stem cells in inducing bone regeneration. Chang Gung Med J. 2012 JanFeb;35(1):28-37.

245. Vallet-Regí M, Ruiz-Hernández E. Bioceramics: from bone regeneration to cancer nanomedicine. Adv Mater. 2011 Nov;23(44):5177-218.

246. Volkmer E, Drosse I, Otto S, Stangelmayer A, Stengele M, Kallukalam B, Mutschler W, Schieker M. Hypoxia in static and dynamic 3D culture systems for tissue engineering of bone. Tissue Eng Part A. 2008 Aug;14(8):1331-40.

247. Wakimoto M, Ueno T, Hirata A, lida S, Aghaloo T, Moy PK. Histologic evaluation of human alveolar sockets treated with an artificial bone substitute material. J Craniofac Surg. 2011 Mar;22(2):490-3.

248. Wang J, Asou Y, Sekiya I, Sotome S, Orii H, Shinomiya K. Enhancement of tissue engineered bone formation by a low pressure system improving cell seeding and medium perfusion into a porous scaffold. Biomaterials. 2006 May;27(13):2738-46.

249. Wang S, Zhang Z, Zhao J, Zhang X, Sun X, Xia L, Chang Q, Ye D, Jiang X. Vertical alveolar ridge augmentation with beta-tricalcium phosphate and autologous osteoblasts in canine mandible. Biomaterials. 2009 May;30(13):2489-98.

250. Wang Y, Uemura T, Dong J, Kojima H, Tanaka J, Tateishi T. Application of perfusion culture system improves in vitro and in vivo osteogenesis of bone marrow derived osteoblastic cells in porous ceramic materials. Tissue Eng. 2003 Dec;9(6):1205-14.

251. Werner S, Grose R. Regulation of wound healing by growth factors and cytokines. Physiol Rev. 2003 Jul;83(3):835-70.

252. Wientroub S, Goodwin D, Khermosh O, Salama R. The clinical use of autologous marrow to improve osteogenic potential of grafts in pediatric orthopedics. J Pediatric Orthop. 1989 Mar-Apr;9(2):186-90.

253. Williams DF. Definitions in Biocompatibility. Proceedings of a Consensus Conference of the European Society for Biomaterials. In: Chester VK, editor. Progress in Biomedical Engineering. v. 4. London: Elsevier Science Publishers; 1987. p. 3-5.

254. Williams DF. On the Nature of Biomaterials. Biomaterials. 2009 Oct;30(30):5897-909.

255. Williams DF. The Williams dictionary of biomaterials. Liverpool: Liverpool University Press; 1999. 
256. Wiltfang J, Kloss FR, Kessler P, Nkenke E, Schultze-Mosgau S, Zimmermann $\mathrm{R}$, Schlegel KA. Effects of platelet-rich plasma on bone healing in combination with autogenous bone and bone substitutes in critical-size defects. Clin Oral Impl Res. 2004 Apr;15(2):187-93.

257. Wiltfang J, Merten HA, Schlegel KA, Schultze-Mosgau S, Kloss FR, Rupprecht $S$, Kessler P. Degradation characteristics of alpha and beta tri-calciumphosphate (TCP) in minipigs. J Biomed Mater Res. 2002;63(2):115-21.

258. Wozney JM. The potential role of bone morphogenetic proteins in periodontal reconstruction. J Periodontol. 1995 Jun;66(6):506-10.

259. Wu Z, Liu C, Zang G. The effect of simvastatin on remodeling of the alveolar bone following tooth extraction. Int J Oral Maxillofac Surg. 2008 Feb;37(2):1706.

260. Xia Y, Mei F, Duan Y, Gao Y, Xiong Z, Zhang T, Zhang H. Bone tissue engineering using bone marrow stromal cells and an injectable sodium alginate/gelatin scaffold. J Biomed Mater Res A. 2012 Apr;100(4):1044-50.

261. Xingdong Z, Yubao L, Ping Z, Cong W, Mutang W. Porous HA ceramics as oral and maxillofacial prostheses. In: Trusu $\mathrm{H}$. editor. Advanced prosthodontics worldwide. Hiroshima: WCP'91; 1991. p. 578-81.

262. Xu L, Lv K, Zhang W, Zhang X, Jiang X, Zhang F. The healing of critical-size calvarial bone defects in rat with rhPDGF-BB, BMSCs, and $\beta$-TCP scaffolds. J Mater Sci Mater Med. 2012 Apr;23(4):1073-84.

263. Yamada S, Heymann D, Bouler JM, Daculsi G. Osteoclastic resorption of calcium phosphate ceramics with different hydroxyapatite/beta-tricalcium phosphate ratios. Biomaterials. 1997 Aug;18(15):1037-41.

264. Ye X, Yin X, Yang D, Tan J, Liu G. Ectopic bone regeneration by human bone marrow mononucleated cells, undifferentiated and osteogenically differentiated bone marrow mesenchymal stem cells in beta-tricalcium phosphate scaffolds. Tissue Eng Part C Methods. 2012 Jul;18(7):545-56.

265. Yilmaz S, Cakar G, Yildirim B, Sculean A. Healing of two and three wall intrabony periodontal defects following treatment with an enamel matrix derivativecombined with autogenous bone. J Clin Periodontol. 2012 Jun;37(6):544-50.

266. Yoo JU, Johnstone B. The role of osteochondral progenitor cells in fracture repair. Clin Orthop Relat Res. 1998 Oct;(355 suppl):S73-81.

267. Yoshikawa T, Ohgishi H, Tamai S. Immediate bone forming capability of prefabricated osteogenic hydroxyapatite. J Biomed Mater Res. 1996 Nov;32(3):481-92. 
268. Yoshikawa $\mathrm{T}$, Ohgushi $\mathrm{H}$, Ichijima $\mathrm{K}$, Takakura $\mathrm{Y}$. Bone regeneration by grafting of culture human bone. Tissue Eng. 2004 May-Jun;10(5-6):688-98.

269. Yuan H, De Bruijn J, Li Y, Feng J, Yang Z, De Groot K, Zhang X. Bone formation induced by calcium phosphate ceramics in soft tissue of dogs: a comparative study between porous alpha-TCP and beta-TCP. J Mater Sci Mater Med. 2001 Jan;12(1):7-13.

270. Yuan H, Fernandes H, Habibovic P, De Boer J, Barradas AM, De Ruiter A, Walsh WR, Van Blitterswijk CA, De Bruijn JD. Osteoinductive ceramics as a synthetic alternative to autologous bone grafting. Proc Natl Acad Sci USA. 2010 Aug 3;107(31):13614-9.

271. Yuan H, Van Den Doel M, L, S, Van Blitterswijk CA, De Groot K, De Bruijn JD. A comparison of the osteoinductive potential of two calcium phosphate ceramics implanted intramuscularly in goats. J Mater Sci Mater Med. 2002 Dec;13(12):1271-5.

272. Yuan H, Yang ZJ, Li YB, Zhang XD, De Bruijn JD, De Groot K. Osteoinduction by calcium phosphate biomaterials. J Mater Sci Mater Med. 1998 Dec;9(12):723-6.

273.Zago MA, Covas DT. Células-Tronco: A Nova Fronteira da Medicina. São Paulo: Editora Ateneu; 2006. 245 p.

274. Zambon R, Mardas N, Horvath A, Petrie A, Dard M, Donos N. The effect of loading in regenerated bone in dehiscence defects following a combined approach of bone grafting and GBR. Clin Oral Implants Res. 2012 May;23(5):591-601.

275.Zhang L, Wang P, Mei S, Li C, Cai C, Ding Y. In vivo alveolar bone regeneration by bone marrow stem cells/fibrin glue composition. Arch Oral Biol. 2012 Mar;57(3):238-44.

276. Zhang X, Yuan H, De Groot K. Calcium phosphate biomaterials with intrinsic osteoinductivity. The 6th World Biomaterials Congress, Hawaii, May 2000.

277.Zhang XD, Zou P, Wu C, Qu Y, Zhang JG. A study of porous block HA ceramics and its osteogeneses. In: Ravaglioli A, Krajewski A. editors. Bioceramics and the human body. Amsterdam: Elsevier; 1991. p. 408-15.

278.Zhang M, Wang K, Shi Z, Yang H, Dang X, Wang W. Osteogenesis of the construct combined BMSCs with beta-TCP in rat. J Plast Reconstr Aesthet Surg. 2010 Feb;63(2):227-32.

279.Zhao Z, Hao C, Zhao H, Liu J, Shao L. Injectable allogeneic bone mesenchymal stem cells: a potential minimally invasive therapy for atrophic nonunion. Med Hypotheses. 2011 Nov,77(5):912-3. 
280. Zhu XD, Zhang HJ, Fan HS, Li W, Zhang XD. Effect of phase composition and microstructure of calcium phosphate ceramic particles on protein adsorption. Acta Biomater. 2010 Apr;6(4):1536-41.

281.Zijderveld SA, Zerbo IR, Van Den Bergh JPA, Schulten EAJM, Ten Bruggenkate CM. Maxillary sinus floor augmentation using a $\beta$-tricalcium phosphate (Cerasorb) alone compared to autogenous bone grafts. Int J Oral Maxilofac Implants. 2005 May-Jun;20(3):432-40. 


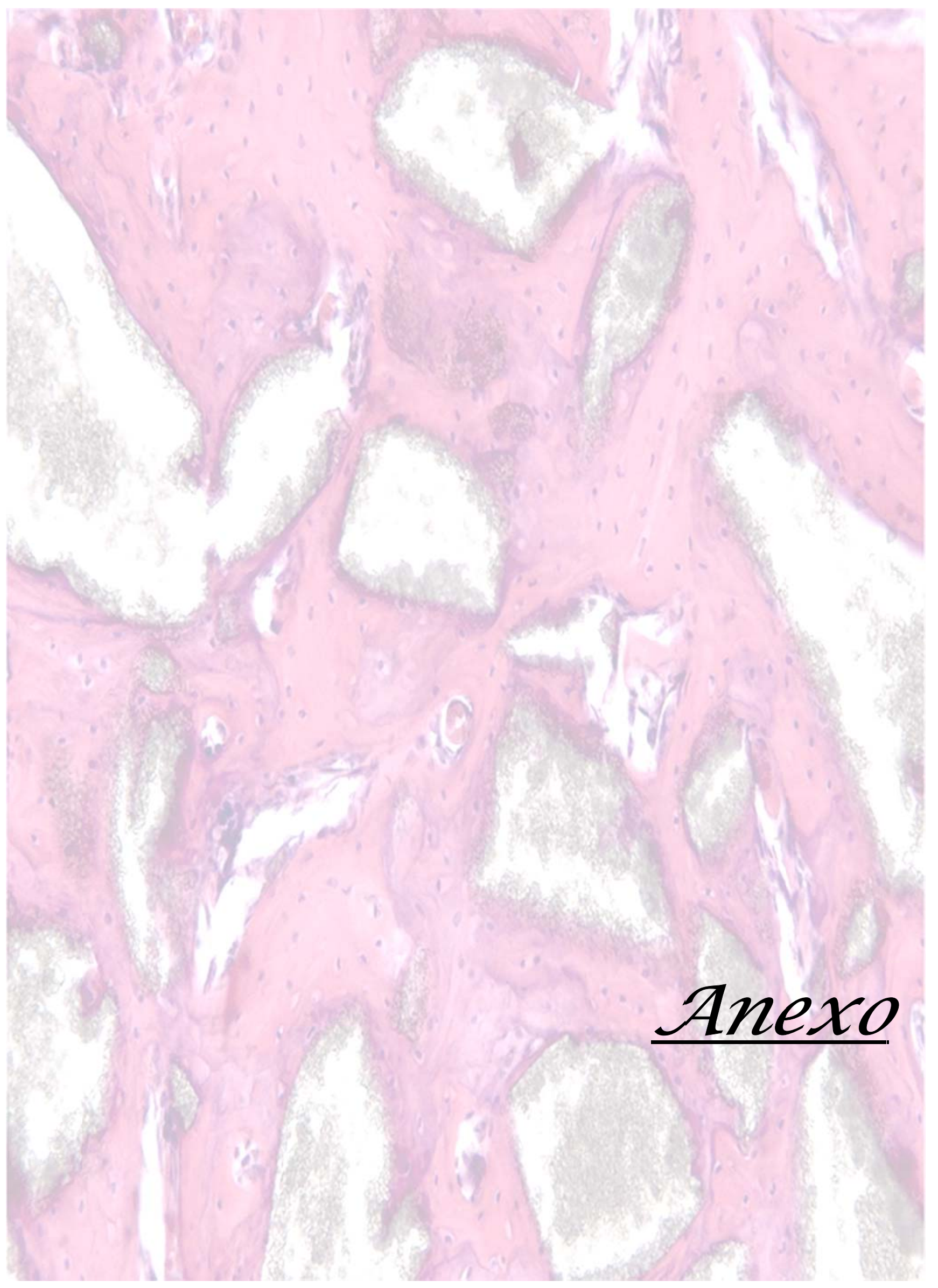




\title{
9. Anexo
}

\section{Parecer do comitê de ética em pesquisa}

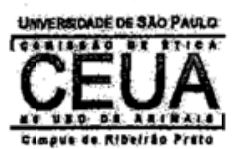

\author{
UNIVERSIDADE DE SÃO PAULO \\ Campus de Ribeirăo Preto \\ Comissão de Ética no Uso de Animais
}

\section{CERTIFI CA D O}

Certificamos que o trabaiho (Proc. $n^{\circ}$ 10.1.644.53.8) intitulado "Quantificação do Potencial Osteogênico in vivo do Osso Autógeno + Células Osteoblásticas Carreadas por uma Biocerâmica (BonecerâmicĐ) Estudo qualitativo em microscopia de luz e eletrônica de varredura" de autoria de Luiz Guilherme Brentegani, por estar de acordo com os Princípios Éticos na Experimentação Animal adotados pela Comissão de Ética no Uso de Animais (CEUA) do Campus de Ribeirão Preto - USP foi aprovado em reunião da CEUA de 04.11.2010.

Colaboradores: Suzie Aparecida de Lacerda José Antonio Tomazini; Karina Fitipaldi Bombonato Prado

Rander Moreira Macedo

This is to certify that the work (Proc. $n^{\circ}$ 10.1.644.53.8), entitled: "Quantificação do Potencial Osteogênico in vivo do Osso Autógeno + Células Osteoblásticas Carreadas por uma Biocerâmica (Bonecerâmic®) Estudo qualitativo em microscopia de luz e eletrônica de varredura", by Luiz Guilherme Brentegani, is in accordance with the Ethic Principles in Animal Experimentation adopted by Ethic Comnission for the Use of Animals (CEUA) of the Campus of Ribeirão Preto - USP, and was approved in the meeting, November 04, 2010.

Ribeirão Preto; 8 de outubro de 2012

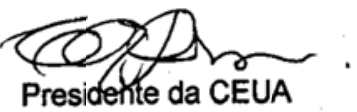

Profa. Dra. Cláudia Maria Padovan

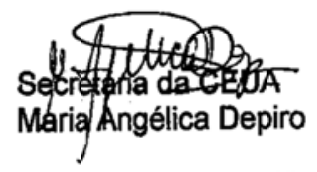

Av. Bandeirantes, 3900 - CEP 14040-900 - Ribeirão Preto - São Paulo Fone: (16) 36024469 - Fax: (16) 36337964 